University of South Florida

DIGITAL COMMONS @ UNIVERSITY OF SOUTH FLORIDA
Digital Commons @ University of

South Florida

$12-1-2006$

\title{
National Smart Transportation Archive Researcher (NSTAR) Best Practices Guide
}

CUTR

Follow this and additional works at: https://digitalcommons.usf.edu/cutr_nctr

\section{Recommended Citation}

"National Smart Transportation Archive Researcher (NSTAR) Best Practices Guide," National Center for Transit Research (NCTR) Report No. CUTR-NCTR-RR-2005-07, Center for Urban Transportation Research, University of South Florida, 2006.

DOI: https://doi.org/10.5038/CUTR-NCTR-RR-2005-07

Available at: https://scholarcommons.usf.edu/cutr_nctr/174

This Technical Report is brought to you for free and open access by the National Center for Transit Research (NCTR) Archive (2000-2020) at Digital Commons @ University of South Florida. It has been accepted for inclusion in Research Reports by an authorized administrator of Digital Commons @ University of South Florida. For more information, please contact digitalcommons@usf.edu. 


\section{National Smart Transportation Archive Researcher Best Practices Guide \\ BD549-20 \\ December 2006 \\ Final Report}

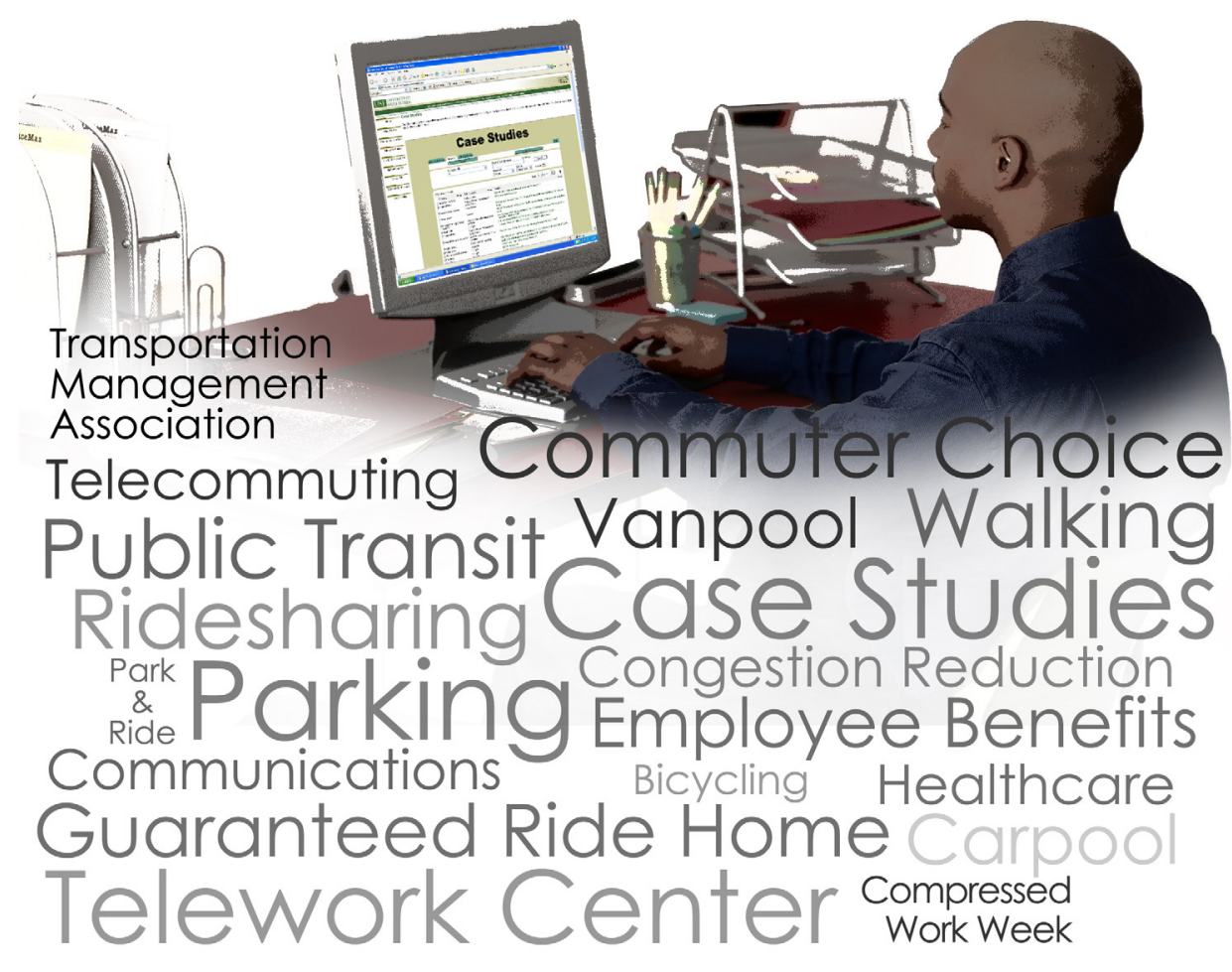




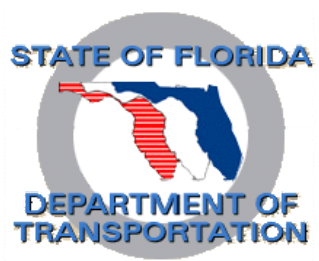

Florida Department of Transportation

Public Transit Office 605 Suwannee Street, MS 26

Tallahassee, FL 32399-0450

(850) 414-4500

Project Manager: Michael Wright

NATIONAL SMART TRANSPORTATION ARCHIVE RESEARCHER

BEST PRACTICES FINAL REPORT

BD549-20

\section{Final Report}

December 2006

\section{Disclaimer}

The opinions, findings, and conclusions expressed in this publication are those of the author(s) and not necessarily those of the State of Florida Department of Transportation. 


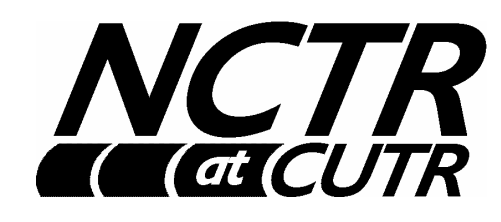

\author{
National Center for Transit Research \\ at the \\ Center for Urban Transportation Research \\ University of South Florida, College of Engineering \\ 4202 E. Fowler Avenue, CUT100 \\ Tampa, FL 33620-5375 \\ (813) 974-3120 \\ Edward Mierzejewski, CUTR Director \\ Joel Volinski, NCTR Director \\ Philip Winters, TDM Program Director, \\ National TDM and Telework Clearinghouse
}

Principal Research Contributors:

Sara Hendricks

Christopher Hagelin

Graduate Student Assistants:

Liren Zhou

Stephanie Bromfield 
Technical Report Documentation Page

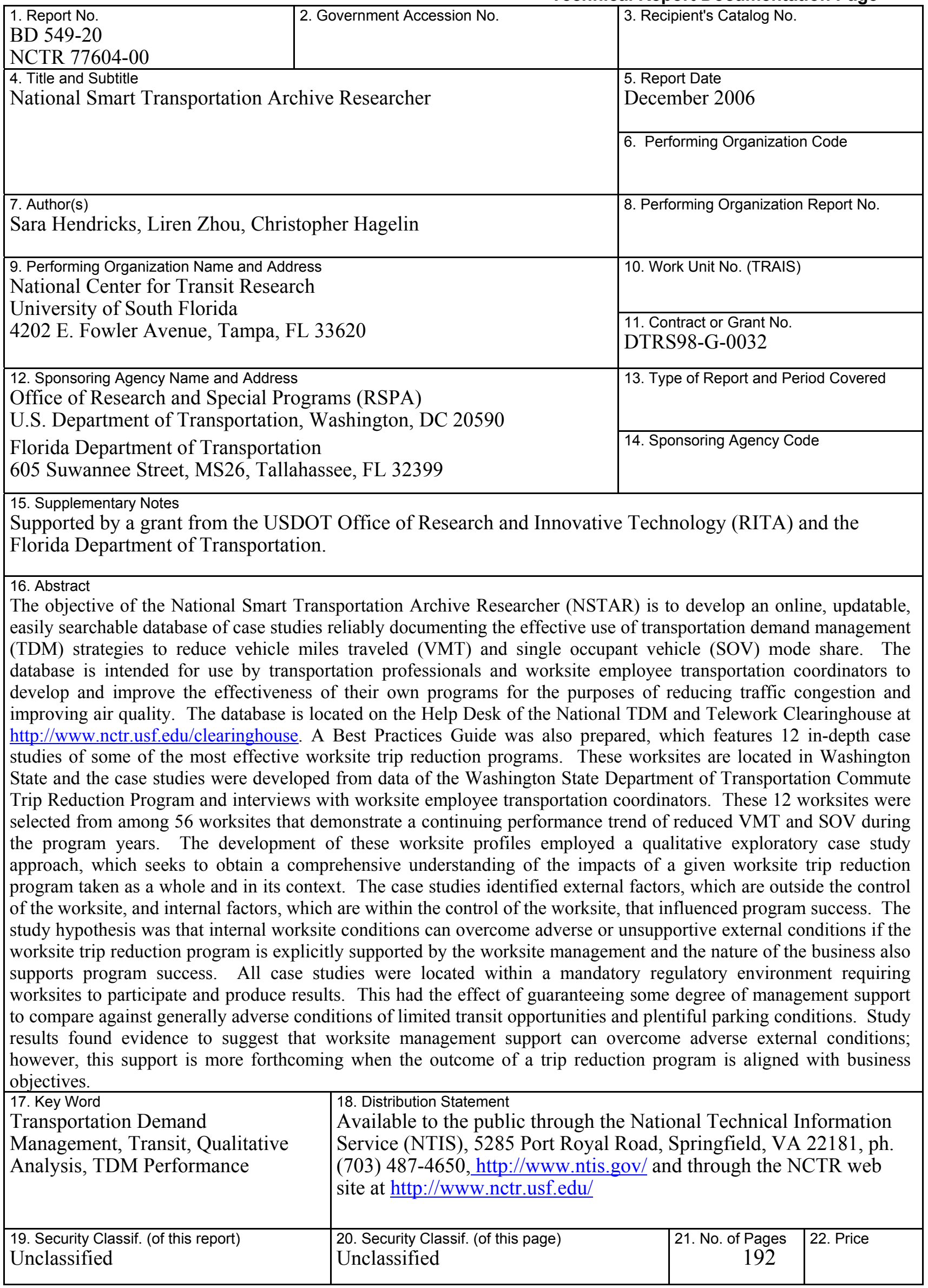

Form DOT F 1700.7 (8-72) Reproduction of completed page authorized 


\section{Acknowledgements}

The authors would like to acknowledge the assistance and case study contributions of the Washington State Department of Transportation, Best Workplaces for Commuters of the U.S. Environmental Protection Agency, the Federal Highway Administration and all other individual contributors to the National Smart Transportation Archive Researcher. The authors would also like to acknowledge the helpful assistance of a panel of expert peer reviewers, including:

Rhonda Danielson, Marketing Representative, Portland Tri-Met

Lori Diggins, Principal, LDA Consulting and Chair, TDM Institute

Brian Lagerberg, Manager, Public Transportation and Rail Division, Washington State Department of Transportation

Sandra Moody, Executive Director, Bay Area Commuter Services, Tampa

Kevin Shannon, Executive Director, Association for Commuter Transportation 


\section{Executive Summary}

The purpose of the National Smart Transportation Archive Researcher (NSTAR) Best Practices Guide is to provide detailed documentation of 12 worksite trip reduction programs that have effectively used transportation demand management (TDM) strategies. NSTAR was undertaken in response to the request by surveyed members of the Association for Commuter Transportation to provide reliable case studies and TDM-oriented statistics. These 12 worksites were carefully selected from over 1,300 worksites in the database of the Washington State Department of Transportation Commute Trip Reduction Program. They were selected based upon their documented continuing trends in program improvement as measured by decreases in vehicle miles traveled and single occupancy mode share over time. It is intended that these case studies and the study findings be used by others to create and modify their own trip reduction programs to make them cost effective and more beneficial to employees. This study was sponsored by the Florida Department of Transportation and funded by the National Center for Transit Research at the Center for Urban Transportation Research at the University of South Florida.

This research employed an exploratory case study approach as used generally in the social sciences and by the United States General Accounting Office in particular. The purpose of this study method is to obtain a comprehensive understanding of the impacts of a given worksite trip reduction program taken as a whole and in its context. The case study analysis focuses upon separating out external factors, or circumstances outside the control of the worksite, from internal factors, which are within the control of the worksite. External factors are of interest in determining beforehand the likely ease or difficulty of implementing a worksite trip reduction program in its physical and political environment. External factors include the presence of mandatory regulation, access to quality public transit service and the availability of public parking. Internal factors are of interest because worksite management can choose to manipulate these factors to improve the success of their worksite trip reduction programs. Internal factors include work scheduling flexibility and not using single occupant vehicle parking privileges as a perk for good performance.

In general, external conditions are more powerful than internal conditions in affecting the success of a worksite trip reduction program. The hypothesis of the study is that internal worksite conditions can overcome adverse or unsupportive external conditions if the trip reduction program is explicitly supported by worksite management and the nature of the business also supports program success. Half of the worksites featured in the NSTAR archive, and now located for public use in the Help Desk of the National TDM and Telework Clearinghouse, were selected based upon the use of three sets of criteria, which were applied successively to the worksites to identify the best candidates for in-depth case study analysis. The worksites featured in the case studies include three hospitals, two colleges, a linen rental service, a public utility, a human resources consulting firm, a computer software research and development company, a correctional facility, and the administrative office for a lumber company. Each case study contains information about worksite characteristics, trip reduction program elements, performance trends, external traffic and parking conditions, availability of outside programmatic support, worksite access to alternative transportation, characteristics of the business, and elements of organizational culture. 
General findings include the following.

- A mandatory trip reduction requirement provides primary motivation for organization management to take action to ensure legal compliance. Characteristics of organizational culture further determine if management believes, "If we have to do a trip reduction program, we are going to do it right."

- In a mandatory trip reduction program environment, it is helpful but not necessary to the success of the commute trip reduction program that the innate characteristics of the work site business type support the commute trip reduction program. For example, work sites that have routine, predictable office hours tend to enable ride sharing.

- In addition to diversity by industry size and type, successful commute trip reduction programs can serve diverse work forces, such as blue collar unionized employees and white collar professionals.

- For a successful commuter trip reduction program, no specific type of administrative program oversight is required as long as the management oversight is supportive.

- Commute trip reduction programs can thrive in varied settings and land development patterns, including rural areas and central business districts.

- Worksites with successful commute trip reduction programs can tolerate free parking.

- Successful worksite trip reduction programs do not necessarily require good access to transit, particularly in terms of peak hour service.

- Traffic congestion is not necessary for a successful trip reduction program.

- Outside support, such as ETC networks, is important to most but not all worksites with successful trip reduction programs.

- A business formal dress code may interfere with successful commute trip reduction programs.

- No specific type of department, i.e., human resources, appears to be a best fit for a successful commute trip reduction program.

- Employee transportation coordinator control over the work site trip reduction program is not necessary where strong program services are already in place and employees are motivated to participate for cost savings.

- Higher worksite financial commitment is needed for participation of higher paid employees at organizations where external conditions are adverse.

The study conclusions also list the many influential internal and external factors that were observed in the 12 worksites. The most influential internal factors include the following.

- The nature of the work does not restrict employees from using alternate modes.

- Motivation of worksite to be legally compliant

- Moderate and lower wage employees seeking transportation cost savings

- Top management and middle management support

- Desired programs and services offered to all employees

- Varied and integrated program offerings to meet diverse commute needs

- Limited on-site parking

- Expensive on-site parking as leased to the employer

- Removal of parking subsidies for employees

- Environmental ethic of commuters 
- Use of alternative modes to advance business objectives. For example, employee ridesharing as a means to socialize new employees into the work environment. New employees are encouraged/expected to join a carpool or vanpool or trip reduction is opportunity to demonstrate good corporate citizenship to the public

- Management desire to attract and retain high quality employees

The most influential external factors include the following.

- Trip reduction ordinance

- Good transit service and transit agencies willing to meet worksite scheduling needs

- Traffic congestion that makes fixed guideway transit service and HOV lanes more time competitive

- $\quad$ Limited public parking

- Gas price increases affected mode share especially for employees with lower wages and for suburban and rural worksites

- Outside Assistance such as ETC networking and training through lunch workshops, ready-made regional marketing campaigns help keep cost of employer-based CTR program lower, and an online commute calendar that the worksite ETCs can use to track employee travel behavior for purposes of reporting and distributing subsidies and incentives

For future research, this study suggests that a hypothesis should be tested to see if under a voluntary environment, the nature of the business has more influence upon the success of a worksite trip reduction program than management support. 


\section{Table of Contents}

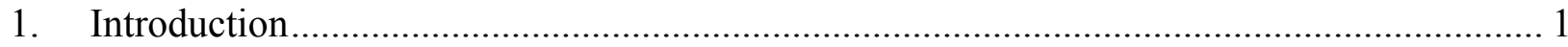

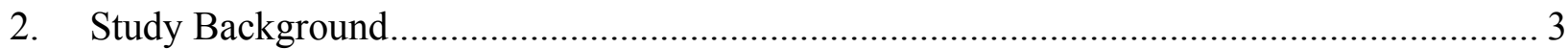

3. Defining Trip Reduction Program Success.................................................................... 5

3.1 What Are "Best Practices"? ................................................................................ 5

3.1.1 Trip Reduction Program Dimensions That Influence Success ............................. 5

4. Statement of NSTAR Case Study Hypothesis ................................................................ 7

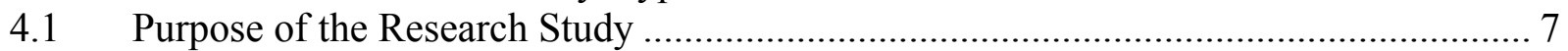

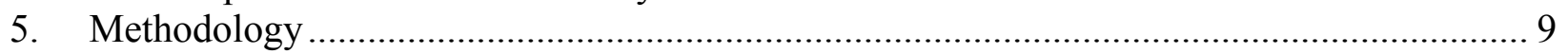

6. Selecting Worksites as Case Studies................................................................................. 13

7. Top Performing Worksites Yield Variety of Industry Size and Type ................................. 15

8. Documentation of Findings From In-Depth Interviews................................................... 17

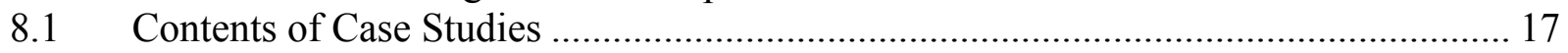

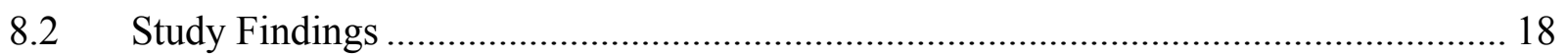

8.2.1 Conclusions from Aggregate Observations ...................................................... 18

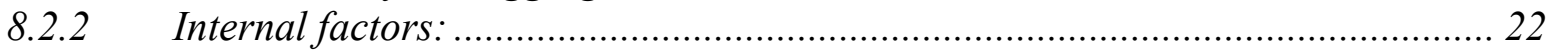

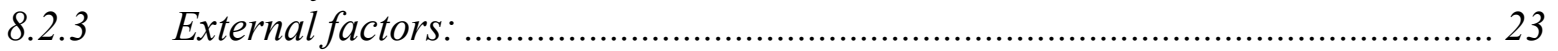

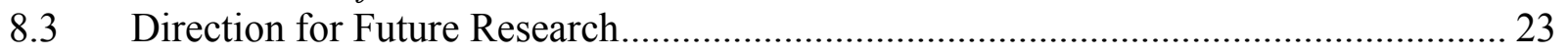

\section{List of Tables}

Table 1: Approximate Annual Cost of CTR Program Per Affected Employee............................. 22

\section{List of Figures}

Figure 1: Percentage of Drive-Alone Commute Trips - Acordia Northwest................................ 37

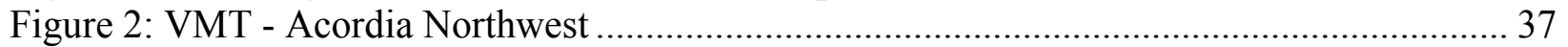

Figure 3: Percentage of Drive-Alone Commute Trips - Alsco ………………………................... 46

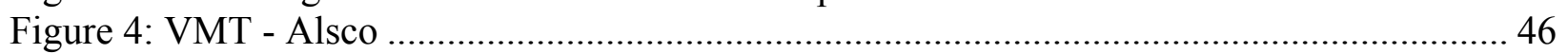

Figure 5: Percentage of Drive-Alone Commute Trips - Eastern State Hospital.............................. 54

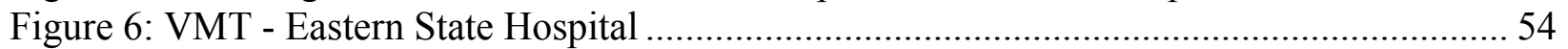

Figure 7: Percentage of Drive-Alone Commute Trips - Evergreen State College ……................ 63

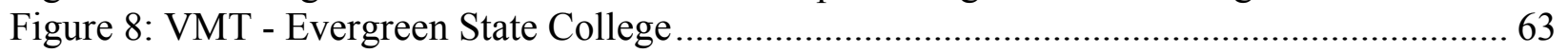

Figure 9: Percentage of Drive-Alone Commute Trips - Mercer HR Consulting............................. 75

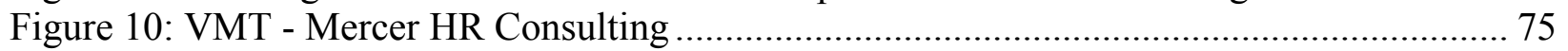

Figure 11: Percentage of Drive-Alone Commute Trips - Microsoft.............................................. 86

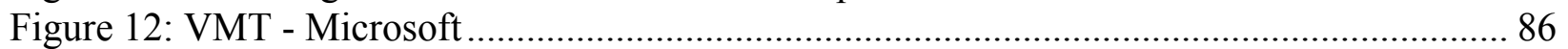

Figure 13: Percentage of Drive-Alone Commute Trips - Pine Lodge Women's Correctional

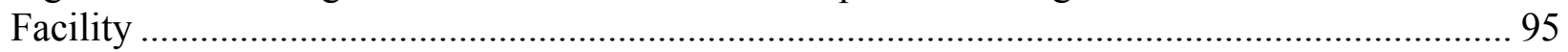

Figure 14: VMT - Pine Lodge Women's Correctional Facility ....................................................... 95

Figure 15: Percentage of Drive-Alone Commute Trips - St. Joseph Hospital.............................. 106

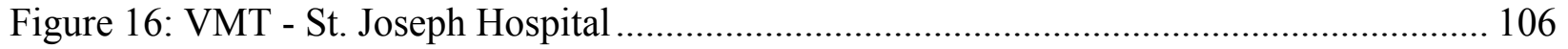


Figure 17: Percentage of Drive-Alone Commute Trips - South Seattle Community College ... 118

Figure 18: VMT - South Seattle Community College .............................................................. 118

Figure 19: Percentage of Drive-Alone Commute Trips - Tacoma Public Utilities .................... 129

Figure 20: VMT - Tacoma Public Utilities ...................................................................... 129

Figure 21: Percentage of Drive-Alone Commute Trips - Virginia Mason Medical Ctr.............. 141

Figure 22: VMT - Virginia Mason Medical Ctr. ....................................................................... 141

Figure 23: Percentage of Drive-Alone Commute Trips - Weyerhaeuser Co.............................. 154

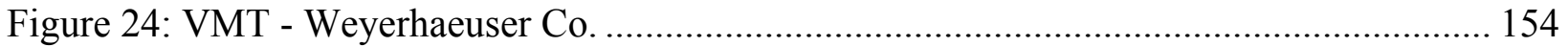




\section{Introduction}

Traffic congestion in urban areas is a major cost to society in lost time and productivity as well as in the production of greenhouse gases and air pollution. As urban areas continue to grow, building more roads is becoming a less practical option, due to growing expense, environmental impacts, legal issues, land unavailability, and neighborhood opposition. Part of the solution is offering more mobility options and reducing the need to travel through programs and services, such as teleworking, ridesharing, transit subsidies and bicycle facilities. This approach is commonly known as transportation demand management (TDM).

Over the years, there has been an increase in requests from employers nationwide for information about the use of various combinations of trip reduction strategies at worksites and their effects upon commuter travel behavior. This information has also been sought by transportation professionals for planning purposes and by commuter assistance programs to assist employers. Worksite Employee Transportation Coordinators (ETC) have valuable information to share and practical insight and know-how from years of combined experience with running Commute Trip Reduction (CTR) Programs. While ETC networking commonly takes place at the local and regional levels, there remains no central source for such information dissemination nationwide.

This research project, the National Smart Transportation Archive Researcher (NSTAR), ultimately seeks to make TDM strategies more useful and helpful to commuters. Sponsored by the Florida Department of Transportation (FDOT) and funded by the National Center for Transit Research (NCTR), NSTAR was undertaken to develop and maintain an online, easily searchable, updatable database for transportation professionals to find reliable case studies on the use of TDM strategies. NSTAR is being offered in response to the 59 percent of respondents to the 2001 Association for Commuter Transportation End-of-Year Survey who requested that TDMoriented statistics and case studies be developed. The Association for Commuter Transportation has coordinated and assisted in the development of NSTAR. NSTAR will be housed within the National TDM and Telework Clearinghouse Help Desk, located at http://www.nctr.usf.edu/clearinghouse.

This database will be used by others to create and modify their own trip reduction programs to make them cost effective and more beneficial to employers. This database contains information from worksite annual reports, travel surveys, and in-depth profiles of worksites that have experienced success with their programs. These worksite trip reduction programs have demonstrated a consistent trend of reduction in vehicle miles traveled and in the drive-alone mode share.

As the NSTAR archive grows and provides more comprehensive information on trends for each case study, the case studies will become increasingly useful to ETCs and transportation professionals. The benefits of this study are twofold. First, by gathering, organizing and providing information about worksite commute trip reduction programs, this will enable worksite ETCs and other transportation professionals to share nationally what program elements have worked well for their organizations in addition to what circumstances have affected implementation. Second, this database development provides researchers with the information needed to analyze the influence of internal and external factors and to generalize about what 
yields good results. The results of this project are intended to provide up-to-date information about strategies used to reduce trip making and the results of those strategies within the context of the particular worksite.

Initially, database development concentrated on the collection and development of case studies that focus upon employer worksite application of TDM strategies. As the database case studies are updated and new case studies are added over time, the database will expand to include TDM strategy applications to special events, incident management, transportation facility construction and maintenance of traffic, school and universities, recreation and tourism, and other applications. Database expansion will also grow to include case studies highlighting:

- One or a combination of TDM strategies

- Application of TDM strategies to transportation management association service areas, citywide, downtowns, corridors, and regions

- More geographic locations

Prior to the preparation of this Best Practices Guide, Technical Memorandum \#1: Literature and Case Study Review and System Design was issued, which contained the results of an examination of the previous Florida Smart Transportation Archive Researcher (FSTAR) system design, a review of other design options for the database, and the development of recommendations for the case study database system design. Subsequent to the review of these recommendations by an expert peer panel, Technical Memorandum \#2: Database User Guide and System Documentation was issued. This document represented the results of the incorporation of peer panel suggestions, the development of the database system, and a graphical user interface. This effort also included the recruitment and development of over 100 case studies.

This Best Practices Guide is the final document of NSTAR and corresponds to Task 4 of the scope of services. It called for the conduct of extensive interviews with up to 12 employers to obtain a comprehensive understanding of the impacts of a given trip reduction program and an analysis of that program "taken as a whole and in its context." While the body of this report provides information about the study hypothesis, methodology, and study findings, Appendix A contains the 12 case studies that will provide readers with detailed information about the worksite and the many factors that influenced the success of their worksite trip reduction programs. These case studies are offered as a resource and guidance for TDM professionals to compare against the special circumstances of worksites they are assisting. Appendix B contains supporting documents that were used during the study to develop the case studies. 


\section{Study Background}

The approach of NSTAR case study development is intended to go beyond anecdotal information about TDM programs. Properly conceived case studies are a research method for attempting valid inferences from events outside the laboratory. Robert K. Yin, Ph.D., defines a case study as "... an empirical inquiry that investigates a contemporary phenomenon within its real life context; when the boundaries between phenomenon and context are not clearly evident; and in which multiple sources of evidence are used."1 Case studies are used, as opposed to other research methods (experiments, surveys, archival histories), when three general conditions are met: when it is desired to learn how or why something is happening, when the investigator has little control over events, and when the focus is on contemporary events within circumstances that affect the outcome of those events (context). The study of TDM programs in this Best Practices Guide is well suited to the case study approach in that it is undertaken to learn how worksite trip reduction programs are successful. Investigators are considered outside observers and not in a position to manipulate or influence program outcomes. TDM programs are contemporary events that are influenced by a number of contextual factors.

In a previous study conducted through NCTR funding and FDOT sponsorship, Commuter Choice Program Case Study Development and Analysis, ${ }^{2}$ the case study approach was also used and provides some background to NSTAR. The earlier focus was upon the impact that internal organizational culture has upon trip reduction program outcomes, as manifested by the influence of the employee transportation coordinator (ETC) and the ETC's supervisor. The hypothesis was that the work style and attitudes of the ETC and the ETC's supervisor do have an influence upon the outcome of a trip reduction program. This was pursued to try to explain the other 82 percent of the variance in effectiveness of one trip reduction program compared to another that is not explained by the combinations of program incentives themselves. ${ }^{3}$

Results from Commuter Choice Program Case Study Development and Analysis found evidence to support that the effectiveness of a worksite trip reduction program sometimes but not always depends upon organizational culture. Case study evidence suggested that, in some cases, the ETC does make a positive difference; however, there are other more potent factors that, when present, control the impact and can either reinforce or undermine the work of the ETC. These factors are, in order of importance:

$\checkmark$ External to and outside the control of the worksite: Good accessibility to high quality alternative public transportation services, namely public transit that provides strong regional accessibility.

\footnotetext{
${ }^{1}$ Yin, Robert K. “The Case Study Crisis: Some Answers.” Administrative Science Quarterly, 26, March 1981, pp. 58-65.

2 "Commuter Choice Program Case Study Development and Analysis." 2004. National Center for Transit Research. University of South Florida, Tampa. Report located at http://www.nctr.usf.edu/pdf/527-06.pdf.

${ }^{3}$ The Trip Reduction Program Model and Manual, developed by the National TDM and Telework Clearinghouse at the Center for Urban Transportation Research, used a neural network to determine the effectiveness of combinations of incentives offered by employers. The initial assumption was that it is the services and incentives offered that will change commuter behavior. However, the model indicated that only 18 percent of the variance in effectiveness of one trip reduction program compared to another was explained by the combinations of incentives themselves.
} 
$\checkmark$ Internal to the worksite and related more to the nature of the business: A worksite employee profile composed of a high proportion of persons with lower incomes. These persons are usually support staff for whom the cost of transportation is more important than the time savings and convenience provided by the transportation. This is not to say that there are no examples of worksites with highly paid professional staff that uses alternative transportation. However, in these cases, the external circumstances are such that congestion is so bad that driving one's car does not offer significant time savings advantages or internally, the organization has a very strong environmental ethic and/or the organization does not provide parking. These are all attributes that the ETC usually does not have control over (employee profile, congestion level, organization ethic, provision of parking) but that prove more powerful than ETC activities.

$\checkmark$ Internal to the worksite: Top management support and advocacy, not only through the offering of program incentives, such as parking cash out, transit subsidies and work hour flexibility, but also through the communication of organizational mission and ethic, as well as rewards to employees for supporting the organization mission and ethic.

In some cases, the importance of a factor depends not only upon its presence but also upon its magnitude. Level of traffic congestion is an example of this. Most commuters will tolerate traffic congestion up to some point but commuter tolerance depends on the individual who will select a unique time versus cash savings balance in mode choice.

A major difference between the Commuter Choice study and the NSTAR case studies is the anonymity of information sources. For the Commuter Choice project, the identities of the organizations as well as the individuals interviewed remained anonymous in order to encourage greater candor in describing internal organizational culture. With the NSTAR project, case study information is being collected with the intent of sharing the identities and experiences of work places with others in the interests of learning from each other's experience, promoting dialogue and duplicating what works elsewhere. The goal is to describe what worksites can do as well as what level of effort is needed and what level of success can be expected under various circumstances.

Clearly, there are other factors, both internal to (within the control of the worksite) and external to (outside the control of the worksite), the combinations in which they appear, the intensity of each factor, and the manner in which each commuter responds, which all influence the success of a trip reduction program. The NSTAR case study archive provides examples of documented trip reduction program success and this Best Practices Guide attempts to better determine what those factors are that promote successful programs. 


\section{Defining Trip Reduction Program Success}

How did the research teeam determine whether a TDM program is successful? There is more than one approach to this. First, success could be measured against the worksite goals. Did the worksite achieve its goals? On one level, this would seem to be the most valid approach because each TDM program is designed only toward achieving worksite goals, regardless whether those goals are worthwhile, reasonable or transferable for use elsewhere. A second approach is to use more "public" measures, based upon what the TDM profession considers a positive outcome, such as demonstration of a trend of decreasing vehicle miles traveled (VMT) and single occupant vehicles (SOV) over the years of a TDM program. A public measure of success might also include achievement of regulatory compliance and objectives as determined by regulators. This uniformity of success measurement makes results easy to track, analyze, and compare across all worksites. A third approach is to incorporate TDM program cost information, so that the results are measured against the price of success. For purposes of this study, high performance has been defined as a sustained trend of improvement toward reduced VMT and reduced SOV. This was decided primarily because the data were available to conduct an analysis and these performance indicators are good measures for reducing traffic congestion and improving air quality. The 12 case study examples featured in this Best Practices Guide all meet that high performance definition.

\subsection{What Are "Best Practices"?}

Best practices include characteristics of a program that deliver desired results, such as meeting commute trip reduction goals and meeting commuter transportation needs, for the least amount of effort and resources. Best practices may differ depending on the circumstances. For example, not all organization business philosophies will be aligned with a commute trip reduction program. In this case, best practices would not observe high effort beyond that which is needed to achieve compliance. There also are examples of high effort and good faith contribution of resources, but low performance in the presence of difficult external conditions. This may be the case of poor transit, plentiful free parking, and sprawling development. The nature of the business may also contribute, such as multiple shifts and the need for employees to travel during the work day. Best practices under poor circumstances may differ from those with more favorable internal and external conditions.

\subsubsection{Trip Reduction Program Dimensions That Influence Success}

Program effort (amount of funding, labor): Program elements (combination and quality): External conditions:

Performance motivation:

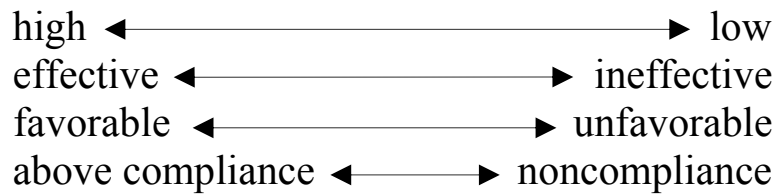

As expected, worksites with these combinations of dimensions are all located along some point on the continuum. 


\section{Statement of NSTAR Case Study Hypothesis}

There are two previous projects that provide a foundation for the NSTAR case study analysis. First, the hypothesis of the study, Trip Reduction Model and Manual, was that various combinations of trip reduction program incentives explain program success. That study found that the incentives alone explain only 18 percent of program performance. The hypothesis of a subsequent study, Commuter Choice Program Case Development and Analysis, was that organizational culture as manifested by the influence of the ETC, explained part of the success of trip reduction programs. The results of that case study analysis found evidence to suggest that, while the ETC can play an important role in program effectiveness, other factors are more important, including, in order of importance, good quality public transportation, moderate income employees who value transportation cost savings above time savings, and management support for the trip reduction program. To continue this investigation, the hypothesis in NSTAR is broader and more exploratory in identifying and discerning the relative importance among various known contributors to trip reduction program effectiveness.

\subsection{Purpose of the Research Study}

In this project, worksites were identified that have demonstrated a trend of decreasing VMT and SOV mode share and for which we have a high level of confidence that the trend is not due to chance. TDM professionals want to know what factors cause this success and can these factors be duplicated by others. Can these factors be controlled by the worksite? Below is a hypothesis statement about combinations of internal elements and the order of importance of those elements.

Base upon evidence from the Commuter Choice project, external conditions are more powerful than internal conditions in affecting the success of a worksite trip reduction program. This means that in the absence of worksite support, favorable external conditions, such as unavailable parking and excellent transit service, will lower VMT and SOV. However, plentiful free parking is often available and there is often a strong market for commuter parking even when it is expensive. Most urban municipal leaders in the United States are loathe to limit city parking availability. Therefore, the typical circumstances encountered by worksite trip reduction programs are adequate parking. Additionally, public transportation services are superior in only a few urban areas in the United States. Most worksite trip reduction programs do not encounter favorable external conditions.

\section{Hypothesis Statement: Internal worksite conditions can overcome adverse or unsupportive external conditions if the trip reduction program is explicitly supported by worksite management and the nature of the business also supports program success.}

Examples of management support include providing employee work hour flexibility and transit subsidies and support for the efforts of the ETC. Examples of the nature of the business include work siting requirements, employee characteristics and skill level, predictability of employee work hours, the necessity for employees to leave the worksite during the work day, the necessity for employees to carry large or heavy items back and forth to work, and dress code. 
In some cases there is a blurring of distinction about whether an element represents worksite management support or the nature of the business. For example, dress code might be considered a flexible option that is set at the discretion of worksite management; however, there are business norms that might dictate otherwise. Corporate attorneys' offices are an example in which business formal is the norm across the industry and is expected by clientele. 


\section{Methodology}

External and internal conditions are listed in the general order of relative importance and described below using the findings of the previous Commuter Choice project as a point of departure. These conditions make up the categories of information collected as part of the indepth interviews.

1. External:

- Worksite accessibility to public transit and public transit service that provides strong regional access

- Land use configuration of surrounding area

- Public parking availability

- Traffic conditions

- Availability of outside support (such as commuter assistance programs)

2. Internal:

- Employee characteristics that influence personal travel decisions

3. Internal:

- Managerial support (organizational culture)

- Nature of the business

- CTR program incentives and services

- Physical facilities on site

4. Internal:

- Effective ETC (one who provides program visibility, encouragement, trouble shooting, individual employee assistance, recognition). Questions were developed with respect to ETC experience, time and level of effort, knowledge, skills, personality and interest in trip reduction.

One way to explain successful programs is to categorize them into three main sets. The first set includes the extreme theoretical case of those worksite trip reduction programs whose success is explained only by factors that are external to the worksite. In the opposite theoretical extreme, the second set includes those worksite trip reduction programs whose success is explained only by factors that are internal to the worksite. The third set is somewhere in the middle of the two extremes and includes those worksite trip reduction programs whose success is explained by some combination of internal and external factors, which is the more common reflection of real conditions. For the purpose of developing best practices, this categorization helps focus upon those conditions that are within the worksite's control.

Anticipated characteristics for the three sets of successful trip reduction programs are described further in this study, based upon findings from the Commuter Choice study.

\section{SET 1: Factors only external to worksite explain trip reduction program success}

This would be illustrative of worksites that either have no trip reduction programs or completely ineffective programs, but nonetheless demonstrate high mode share for alternative modes and low vehicle miles traveled. These are often downtown or business district locations. 
Ideal external factors outside the control of the worksite

- Good accessibility to high quality alternative transportation services, namely public transit that provides strong regional accessibility.

- Supportive land use configuration (transit-oriented development).

- Lack of public parking availability.

- Regulatory worksite trip reduction program requirement.

- Traffic congestion bad enough that:

$\checkmark \quad$ Time savings are negligible: Driving one's car does not offer significant time savings over riding transit. This neutralizes any effect that employee income level has on choice of modes.

$\checkmark \quad$ Driving is stressful: Unpredictable congestion, stop/go, frequent accidents that cause tie-ups, unpleasant weather for driving, sun glare, road construction and detours, malfunctioning traffic signals, aggressive drivers, and other factors that make the driving experience unpleasant.

- Presence of outside support, such as CAP or TMA services.

\section{SET 2: Factors only internal to worksite explain trip reduction program success}

\section{Internal factors within the control of the worksite (describing an ineffective program)}

- Worksite location decisions made on basis of factors other than employee commuter access.

- Absence of supportive organizational culture (no influence) or adversarial internal culture (success despite internal culture).

- Unappealing trip reduction program incentives.

- Ineffective ETC.

\section{In the presence of supportive external conditions}

This would be a rare scenario in which the worksite is successful but its success has nothing to do with supportive external conditions. This might be the example of a sheltered worksite, located centrally in an urban area, for persons with disabilities who travel using only private shuttles operated by the worksite.

\section{In the presence of adverse external conditions}

This is the case in which there is no trip reduction requirement, no public alternative transportation services (or public transportation is present but functions less well than driving alone.) In the presence of alternative transportation, employee income levels at the worksite make a difference whether it is used. The following are examples of external conditions that are adverse to work site trip reduction program success.

- Traffic congestion not "bad enough."

- Public parking plentiful.

- Driving experience not stressful.

- Poor or nonexistent public transit, vanpooling or commuter assistance programs.

- Land use configuration designed for private auto travel (suburban).

- No outside support from CAP, TMA or other service provider. 
In the presence of supportive internal conditions, there may be both worksite management support and the nature of the business also supports program success.

Ideal worksite characteristics might include the following:

- Advantageous worksite location decisions were at least partly based upon providing employee commuter access.

- Worksite internal culture is philosophically supportive of alternative transportation (motivation of organization is not solely regulatory compliance). This has the effect of recruiting and retaining employees who also feel philosophically aligned.

- Trip reduction program services and incentives that provide timely transportation at a competitive price. Programs will vary based on employee characteristics.

- Voluntary trip reduction program compliance.

- ETC thinks top managers believe trip reduction program is important. This has the effect of motivating employees to participate in trip reduction because it will advance their career at the organization.

- Employees remain at the worksite during the work day (they do not have to travel).

- The nature of the job does not require employees to bring their own tools or carry heavy or many things, merchandise samples, large briefcases, etc. This generally means an office setting.

- Employees work routine, predictable hours.

- Management provides no encouragement to upper-income employees to drive-alone (no prestigious parking privileges).

- $\quad$ ETC cites no distinction of commuting behavior by salary level.

- ETC and supervisor have access to and influence upon trip reduction program budgetary decision maker.

- ETC thinks there is adequate funding for the worksite trip reduction program.

- ETC has a high "i" work style (DiSC $\left.{ }^{\mathrm{TM}}\right)$ : those who enjoy influencing others, seek contact with all types of people, look for opportunities to generate enthusiasm and accomplish goals through others. They are adept at dealing with people and articulate their ideas well. ${ }^{4}$

- ETC volunteered for the position of ETC.

- ETC holds at least a mid-level position and has program autonomy.

- ETC duties are explicitly listed as part of written job description.

- ETC has served longer than five years and is experienced.

- ETC reports to one person only, eliminating conflict of duties.

- ETC duties require coordination with others, which invests the support of others.

- Presence of internal worksite "champions" of alternative modes.

In the presence of supportive management, the nature of the business might not support program success. In this case, ideal worksite characteristics might include all of the above except that the

\footnotetext{
4 "Commuter Choice Program Case Study Development and Analysis." 2004. National Center for Transit Research. University of South Florida, Tampa. Located at http://www.nctr.usf.edu/pdf/527-06.pdf
} 
worksite trip reduction program is tailored to overcome obstacles resulting from the nature of the business. Obstacles that must be overcome might include the need for a remote setting where public transit cannot serve, work that requires employees to travel, work that requires transport of heavy or bulky items, and unpredictable work hours or "on-call" hours.

In the absence of supportive management, worksite trip reduction program success might simply be due to the nature of the business only. Worksite characteristics might include:

- Advantageous worksite location decisions were based upon providing employee commuter access for purely business motives.

- Employees remain at the worksite during the work day (they do not have to travel).

- The nature of the job does not require employees to bring their own tools or carry heavy or many items, merchandise samples, large briefcases, etc. This generally means an office setting.

- Employees work routine, predictable hours.

\section{SET 3: Factors both internal and external to worksite help explain trip reduction program success}

It was anticipated that this category will contain the majority of worksites. Specifying the possible combinations of internal and external factors are too numerous to list. However, each worksite trip reduction program will exhibit the factors listed above to some degree. It was anticipated that other factors not previously identified will also be found.

Generally, external factors are outside the control of the worksite; however, a worksite can choose to overcome external factors by, for example, locating itself to minimize the outside adversarial conditions that would otherwise be outside its control. Generally, internal factors are within the control of the worksite; however, for example, the very nature of the business may pose obstacles for implementing a trip reduction program. 


\section{Selecting Worksites as Case Studies}

To find examples of worksites that meet the definition of successful trip reduction programs, the dataset from the Washington State Commute Trip Reduction Program was used. It is a large dataset of over 1,300 worksites with complete information on commute trip reduction program characteristics, worksite characteristics, baseline program performance, and performance trends for successive years. The data are also certified as accurate and correct by the worksite representatives. To select worksites to use as case studies of best practices, several criteria were progressively applied. Worksites were first selected based upon availability of data for the most recent study years. These included worksites for which there were surveys completed in 2003 and annual reports completed in 2004. Worksites without this information were excluded under the assumption that these worksites are no longer participating in the trip reduction program. These criteria reduced the eligible worksites from a total of 1,321 before the criteria were applied to 776 worksites. Second, the 776 worksites were reduced further based on the availability of at least five survey records and at least four annual report records, in order to demonstrate a performance trend. This reduced the sample of interest to 408 worksites. Next, we selected those worksites for which the trend line slope of VMT is negative. In other words, the number of vehicle miles traveled by commuters from a worksite is decreasing over time. This reduced the sample of worksites to 217. Then the R square for VMT was calculated and worksites were further selected based upon an $\mathrm{R}$ square more than 0.5. This means that there is greater confidence that the downward slope in VMT is not random or due to chance. This further reduced the number of worksites to 72. Additionally, the trend line slope for driving alone was graphed, further reducing worksites to 59 whose trend line slope was negative, meaning that the mode share for driving alone by commuters from those worksites is decreasing over time. The $\mathrm{R}$ square was again calculated to find that a total of 33 worksites indicated an R square greater than 0.5. There is greater confidence that the decrease in drive-alone mode share over time is not random or due to chance. These steps are summarized here.

\section{$\underline{\text { Selection Criteria Stage A: }}$}

1. The last year survey available: 2003 (Number of worksites: 993)

2. The last year annual report available: 2004 (Number of worksites: 776)

3. Number of survey records available: at least 5 (Number of worksites: 442)

4. Number of annual report records available: at least 4 (Number of worksites: 408)

5. Trend line slope of VMT is negative (Number of worksites: 217)

6. R square of VMT is more than 0.5 (Number of worksites: 72)

7. Trend line slope of driving alone is negative (Number of worksites: 59)

8. R square of driving alone is more than 0.5 (Number of worksites: 33 )

A total of 33 work sites derived from Selection Criteria Stage A were judged an insufficient pool of prospective work sites from which to contact for in depth case study development. As a result, two more sets of criteria were developed and applied independently to the initial 1,300 work sites, then compared to see if other good candidate work sites were identified by the process. Selection Criteria Stage B is different from Stage A in that the number of annual reports available and the most recent year that an annual report is available does not have to be 2004 . The number of survey records that are available are at least four instead of five. Primary 
businesses of Government, Education Military and Transportation were excluded in Stage B because these types of work sites are either unusual in number and therefore not typical or those types of work sites are more naturally inclined to have high performing trip reduction programs because of the nature of the organization. Criteria Stage B yielded nine additional work sites not otherwise selected under Criteria Stage A.

$\underline{\text { Selection Criteria Stage B: }}$

1. The last year survey available: 2003 (Number of worksites: 993)

2. Number of survey records available: at least 4 (Number of worksites: 662)

3. Trend line slope of VMT is negative (Number of worksites: 331 )

4. R square of VMT is more than 0.5 (Number of worksites: 102)

5. Trend line slope of driving alone is negative (Number of worksites: 83 )

6. R square of driving alone is more than 0.5 (Number of worksites: 49)

7. Primary business is not "Government", "Education", "Military", "Transportation" (26)

8. Total number of employees less than 500 (21)

9. Does not include all records selected by criteria A (9)

Selection Criteria Stage C:

Restriction \#6 from Criteria Stage B was deleted, which makes Criteria Stage C less restrictive. Stage $\mathrm{C}$ yielded an additional 15 work sites not selected by Criteria Stages B and A.

Applying the criteria stages A, B and C above yielded a sum of 56 worksites of interest in Washington with high performing and effective worksite trip reduction programs. All sites were located in the Puget Sound region except for six in Spokane County. The remaining sites were 40 in King County, two in Whatcom County, one in Snohomish County, one in Kitsap County, three in Pierce County, and three in Thurston County. All of these worksites have program and performance documentation included in the NSTAR database found on the National TDM and Telework Clearinghouse Help Desk. 


\section{Top Performing Worksites Yield Variety of Industry Size and Type}

After identifying case studies of high performance, we examined them for patterns and characteristics. A scan of these 56 worksites indicated a large variety in worksite size from 100 to several thousand employees. Many industries are represented, including hospitals; local, state, and federal government offices; community colleges, technical institutes and universities; professional consultants, including transportation engineering, attorneys, human resources, banking, advertising and insurance; research and manufacturing, including electronics, appliances, computer hardware and software, forest products, glass products and doors; a hotel, a retailer, a linen service, a water utility, a national park, a TV news station and a prison. Job classifications of participating worksite employees represent diverse sectors, including professional, laboratory, retail, service, clerical and administrative, manufacturing, skilled and unskilled workers. This suggests that effective trip reduction programs are not necessarily associated with organization size, industry type or job type.

Per the guidelines of the project scope, 12 worksites were selected from the 56 high performing worksites to develop in-depth case studies. It was decided to feature six worksites from King County, since King County represents well over 50 percent of the worksites with high performing programs, and six more from the other counties. Perhaps the most important deciding factor in final selection of the worksites was willingness of the ETCs and approval by their organization management to allow the worksites to be featured in the study. A selection deemphasis was made on worksites that may have an unusual motivation to perform highly, thereby not reflecting conditions of "typical" worksites. For example, de-emphasized worksites included government offices with a stake in commute trip reduction (U.S. EPA) as well as transportation consultants. Effort was made to select a variety of worksites representing urban, suburban and rural, large and small (approximately 100 employees), and different types of industry classifications.

The worksite selection and contact process began with discussions with Washington State Department of Transportation (WSDOT) staff about the 56 worksites, followed by contact with the Commute Trip Reduction (CTR) coordinators at the County level. These CTR coordinators received information about the study as well as a listing of the specific 56 worksites to be contacted. ETC contact information of the worksites was verified with the CTR Coordinators. The contacting of ETCs began with a phone call and follow-up with a letter of introduction to the study and an informed consent form, per the requirements of the Institutional Review Board for federally funded research. ETCs who consented to be interviewed were then emailed a brief survey to verify various data about their programs as well as an interview guide that contained a series of questions on topics including: 
- worksite accessibility to public transit,

- land use configuration of the area surrounding the worksite,

- public parking availability,

- off-site traffic conditions,

- physical facilities of the worksite,

- commute trip reduction program characteristics,

- work force characteristics,

- nature of the business,

- organizational culture, and

- the employee transportation coordinator. 


\section{Documentation of Findings From In-Depth Interviews}

\subsection{Contents of Case Studies}

Each case study write-up contains an in-depth analysis of the internal and external factors that have influenced the effectiveness of the CTR program. Multiple sources of evidence were sought to compose the case studies. Information was obtained from interviews with the worksite Employee Transportation Coordinators and from organization web sites. In addition, each case study write-up also contains a summary of descriptive information, program elements and performance trend data in tabular, text, and graph form from information derived from the Washington State DOT Commute Trip Reduction Program. Each case study write-up contains the following.

- Name and location

- Organization Information

- CTR Program contact

- Worksite characteristics

- Summary program narrative

- Program elements listed by successive program year

$\checkmark$ Worksite parking and parking management information

$\checkmark$ Program promotion

$\checkmark$ Site amenities

$\checkmark$ Financial subsidies

$\checkmark$ Fleet vehicles and special programs

$\checkmark$ Mode split and vehicle miles traveled

$\checkmark$ Compressed work week, flex time and teleworking

- Graphs of change in average vehicle miles traveled (VMT) per one-way commute

- Graphs of change in percentage of employees traveling by single-occupant vehicles

An in-depth program narrative derived from an interview adds some combination of the elements below based upon what factors appear influential. The narrative includes an interpretation of the information and points out trends.

- Worksite characteristics

- Land use configuration of surrounding area

- Public parking availability

- Traffic conditions

- Availability of outside support

- Commuter assistance program characteristics

- Conditions internal to the worksite

$\checkmark$ Worksite accessibility to public transit/regional accessibility

$\checkmark$ Physical facilities

$\checkmark$ Employee characteristics

$\checkmark$ Nature of business

$\checkmark$ Organizational culture

$\checkmark$ Employee transportation coordinator 
Eleven of the 12 participating worksites examined in depth for this study were located in the Puget Sound region of Washington State. The other was from Spokane. There were three hospitals, two colleges, one city public utility, one state prison, a linen rental facility, the administrative offices for a lumber company, a computer software research and development company, a human resource consultant and an insurance broker. They are listed below.

1. Acordia Northwest, Inc., Seattle

2. Alsco, Spokane

3. Eastern State Hospital, Medical Lake

4. Evergreen State College, Olympia

5. Mercer Human Resource Consulting, Seattle

6. Microsoft Corporation, Issaquah

7. Pine Lodge, Medical Lake

8. Saint Joseph's Hospital, Bellingham

9. South Seattle Community College, Seattle

10. Tacoma Public Utilities, Tacoma

11. Virginia Mason Medical Center, Seattle

12. Weyerhaeuser Company, Federal Way
Insurance broker

Linen service

Hospital

College

Professional consulting

Information services

Women's correctional facility

Hospital

College

City service provider

Hospital

Forest products (administrative office)

\subsection{Study Findings}

None of the case studies fit the description of having a successful trip reduction program due to internal conditions only or due to external conditions only. All 12 case studies fit the description of Set 3, in which some combination of external (outside worksite control) and internal (within worksite control) conditions were present to influence the trip reduction program success. Additionally, all 12 cases studies fit the description of the hypothesis below, in which there is both worksite support and the nature of the business allows for program success.

Generally, external conditions outside worksite control trump internal conditions in affecting the success of a worksite trip reduction program. However:

Hypothesis Statement: Internal worksite conditions can overcome adverse or unsupportive external conditions if the trip reduction program is explicitly supported by worksite management and the nature of the business also supports program success.

Where the nature of the business might not support program success, the presence of supportive management might nonetheless result in a successful trip reduction program. Alternatively, in the absence of supportive management, worksite trip reduction program success might simply be due to the nature of the business only.

\subsubsection{Conclusions from Aggregate Observations}

The discussion below describes comparative observations about the 12 case studies and what might be concluded from these observations.

1. A trip reduction requirement provides primary motivation for organization to take action to ensure legal compliance. Characteristics of organizational culture further determine if management believes, "If we have to do a trip reduction program, we are 
going to do it right." All except one worksite are under mandatory requirement to participate in the Washington CTR Program, and the one voluntary worksite was recently previously required to participate. This worksite is now continuing its CTR program while the number of its employees is currently under 100 .

\section{In a mandatory regulatory environment, alignment of the nature of the business with the commute trip reduction program is not necessary but helpful.}

The ETCs from half of the 12 worksites stated that their organizations' business philosophy is aligned with the intent of the CTR program. Three more worksites stated that the worksite business philosophy was unrelated to the CTR program. Six worksites cited business benefits as a motivator to comply with the CTR program and four more worksites cited their CTR programs as opportunities to demonstrate corporate responsibility and mitigate industrials impacts of the business (some worksites selected more than one descriptor). A possible corollary is that, without regulation, alignment with the nature of the business and management support become necessary where employees have high incomes and driving to work is easy. This business philosophy alignment and management support is easier to come by where the CTR program provides business benefits. Indeed, some case studies show that where the CTR program serves business objectives, the organizational culture can exert a strong influence upon program performance. For example, internal ridesharing arrangements can be used to socialize new employees into the organization culture, as in the case study of Tacoma Public Utilities. Ridesharing arrangements can also provide mutual social support among employees sharing a stressful work environment, as in the case study of Pine Lodge.

There is evidence to suggest that the nature of the business has at least as much influence on the success of the worksite trip reduction program as worksite management support. For example, hospital work sites, as illustrated by three of the case studies, tend to have more to gain than to lose by providing commuter services to employees. While management could likely overcome any difficulties due to the nature of the business, it is more likely in a voluntary regulatory environment that management would have little or no interest in overcoming difficulties due to the nature of the business. This is because a trip reduction program would run counter to business interests if the effort impeded business in some way, or was perceived as too expensive, as in the case of headquarters management reaction to the ETC's transit subsidy at Mercer Human Resource Consulting.

3. In addition to diversity by industry size and type, successful commute trip reduction programs can serve diverse work forces, such as blue collar unionized employees and white collar professionals. One worksite, Alsco, employed lower-wage entry level employees. The other 11 worksites generally employed a mix of highly-paid professionals and moderately-paid administrative, clerical and facilities employees. The moderately paid employees, such as at Acordia Northwest, were more likely to constitute the majority of alternative mode users and to decide upon a commute mode based upon cost savings. Higher paid employees, such as hospital physicians can afford to place a higher value upon convenience, time savings and schedule flexibility provided by SOV driving; however, a few higher paid employees do use alternative modes to demonstrate political leadership, support the organization's programs, for exercise, and even for the "joy" or "virtue" of thriftiness. At Alsco, economics drives the internal ridesharing 
because of the entry level employees. At Evergreen State College, staff is environmentally aware and individuals feel a greater sense of personal responsibility. At St. Joseph's Hospital, good health and wellness are important values to employees and the health connection is made to the trip reduction program.

4. For a successful commute trip reduction program, no specific type of administrative program oversight is required as long as the oversight is supportive. Ten of the 12 worksites are part of larger companies with other offices elsewhere. Five of these 10 worksites have commute trip reduction programs that are centrally managed by a headquarters office and three more indicated that their trip reduction programs are managed at the individual worksite.

5. Commute trip reduction programs can thrive in varied settings and land development patterns, including rural areas and central business districts. Four worksites represent downtown central business district locations, five represent suburban locations and three represent rural locations.

6. Worksites with successful commute trip reduction programs can tolerate free parking. Eight of the 12 worksites offer free on-site parking. Three of the 12 worksites offer reserved free parking to high level employees. Superior transit service does not match the freedom and doorto-door service of driving one's own vehicle. For organizations that must recruit the highest skilled employees, free parking remains a necessary perk, such as at Mercer Human Resource Consulting.

7. Successful worksite trip reduction programs do not necessarily require good access to transit, particularly in terms of peak hour service. Public transit is the main alternative mode used by downtown employees but not elsewhere. For worksites with no transit or poor transit availability, distance from the transit stop appeared more important than headway. For example, in the case of Alsco, where lower wage workers might otherwise use transit, a physical barrier made access to transit difficult. One worksite had no access to public transit while the other eleven worksites had transit access at least $1 / 4$ mile or closer to the worksite. Six of the 12 worksites had an on-site transit stop, some with transit headways as long as 60 minutes during peak commuting times and others as short as 5-10 minutes. Transit use dropped precipitously at worksites outside downtown locations as headways increased. For example, ridesharing at Microsoft's suburban campus is the alternative mode of choice, especially since it enables use of HOV lanes.

8. Traffic congestion is not necessary for a successful trip reduction program. Not all worksites with successful commute trip reduction programs experience bad traffic congestion, such as the work sites located in rural areas. Perceived traffic congestion ranged from free flow to gridlock. The ETC for one downtown worksite, Acordia Northwest, observed that traffic is not at all bad in the downtown unless there is a special event. The worst traffic congestion appears to be experienced by most, not in the downtown core itself but the on the major highways that downtown workers use to enter and leave the downtown, in areas just outside the downtown. The ETC of only one work site, Weyerhaeuser Company in the satellite activity center of Federal Way, perceived that traffic had worsened in the past year. 
9. Outside programmatic support is important to most but not all worksites with successful commute trip reduction programs, particularly those located near high quality transit. Nine of the 12 worksites used outside support for their commute trip reduction programs. For those worksites outside King County especially, the ETCs depended on the regional programs, the regional promotional campaigns, and the ETC networks for support, time savings, and knowledge about how to provide assistance.

10. A business formal dress code may interfere with successful commute trip reduction programs. No worksites among the 12 case studies had a business formal dress code. Dress codes are business casual, casual, uniforms, and work clothes. In general, casual dress codes allow a greater physical ease to walk to work or walk to a transit stop.

11. No specific type of department, i.e., human resources, appears to be a best fit for a successful commute trip reduction program. There is a general perception that commute trip reduction programs are supposed to be housed in a Human Resources department. In actuality ETCs of successful programs are employed in a number of different departments, including Administration, Human Resources, Parking, Security, Facilities Operations, Transportation, and Community Relations/Media Services.

12. ETC control over the work site tip reduction program is not necessary where a strong program is institutionalized through policy, procedures or services, such as providing a 100 percent transit subsidy, and employees are motivated to participate for cost savings. While some ETCs are mid-level managers with high influence and autonomy, other ETCs are administrative assistants with no decision making power and who simply administer the program. Two of the 12 worksites have full time ETCs. These positions appear to be associated with highly profitable businesses located on suburban campus worksites and with the necessity for someone to oversee shuttle operation. However, ETCs of some other worksites devote no more than two hours per week and their programs are still successful. Where external conditions are not supportive to trip reduction programs, it becomes more important for the ETC to have input into the budget for the trip reduction program, influence over how the budget is spent, and autonomy in making decisions to develop services and run the program.

13. Higher worksite financial commitment is needed for higher paid employees at organizations where external conditions are adverse. The table below summarizes the funding provided to the 12 highlighted programs in this study. The wide variation suggests that some companies must provide more incentives to use alternative transportation options than other companies. Where there are highly-paid white collar employees in a suburban setting and transit service cannot provide the time savings that driving alone can, more effort and resources must go into providing highly tailored programs. Where there are lower wage entry level employees, the employees have no choice but to value cash savings over time savings and will always take the least expensive transportation option. Sometimes the employer must even provide effort to enable the employees to access the worksite if there is poor or nonexistent transit service, as in the case of Alsco. In this case the employer's goal is not to shift mode share but simply to transport employees to the worksite. Where there is superior transit service with comparable time savings and unavailable parking, little effort is needed to shift modes to transit. 
Where there is good transit service but available parking, transit subsidies are needed to win moderate-income employees to ride transit, unless the parking is exorbitantly expensive.

Table 1: Approximate Annual Cost of CTR Program Per Affected Employee

\begin{tabular}{|c|c|c|c|}
\hline Organization Name & $\begin{array}{l}\text { Number of } \\
\text { Affected } \\
\text { Employees }\end{array}$ & $\begin{array}{c}\text { Last Year's } \\
\text { Approximate Total } \\
\text { CTR Program } \\
\text { Annual Cost }\end{array}$ & $\begin{array}{c}\text { Annual } \\
\text { Program Cost } \\
\text { per Affected } \\
\text { Employee }\end{array}$ \\
\hline Acordia Northwest, Inc. & 100 & $\$ 56,000$ & $\$ 560$ \\
\hline Alsco & 160 & $\$ 6,000$ & $\$ 37.50$ \\
\hline Eastern State Hospital & 350 & $\$ 75,000$ & $\$ 214$ \\
\hline Evergreen State College & 391 & $\$ 5,000$ & $\$ 12.79$ \\
\hline Mercer Human Resource Consulting & 206 & $\$ 130,000$ & $\$ 631$ \\
\hline Microsoft Corporation & 2,034 & $\$ 2,000,000$ & $\$ 983$ \\
\hline $\begin{array}{l}\text { Pine Lodge Women's Correctional } \\
\text { Facility }\end{array}$ & 114 & $\begin{array}{l}\text { Quarterly gift } \\
\text { cards to random } \\
\text { drawing winners }\end{array}$ & minimal \\
\hline Saint Joseph's Hospital & Approx. 100 & $\$ 60,000$ & $\$ 600$ \\
\hline South Seattle Community College & 160 & $\$ 160,000-\$ 200,000$ & $\$ 1,000-\$ 1,250$ \\
\hline Tacoma Public Utilities & 900 & $\$ 7,000$ & $\$ 7.75$ \\
\hline Virginia Mason Medical Center & 1,600 & $\$ 582,500$ & $\$ 364$ \\
\hline Weyerhaeuser Company & 538 & $\$ 450,000$ & $\$ 836$ \\
\hline
\end{tabular}

In summary, numerous internal factors contributed to worksite trip reduction program success, as listed below.

\subsubsection{Internal factors:}

Absolutely necessary in a non-mandatory trip reduction program environment:

- The nature of the work does not restrict employees from using alternate modes.

Probably more important:

- Motivation of worksite to be legally compliant

- Moderate and lower wage employees seeking transportation cost savings

- Top management and middle management support

- Desired programs and services offered to all employees

- Varied and integrated program offerings to meet diverse commute needs

- Limited on-site parking

- Expensive on-site parking as leased to the employer

- Removal of parking subsidies for employees

- Environmental ethic of commuters

- Use of alternative modes to advance business objectives. For example, employee ridesharing as a means to socialize new employees into the work environment. New employees are encouraged/expected to join a carpool or vanpool or trip reduction is opportunity to demonstrate good corporate citizenship to the public

- Management desire to attract and retain high quality employees 


\section{Not necessary but can make a good program into a great program:}

- Employee committee

- Enthusiastic and conscientious ETCs with valued knowledge about facilities management and commute options, access to top management, resources and autonomy to operate the program or enthusiastic and conscientious ETCs who may lack power but whose job is simply to administer an effective program

- ETCs who use alternative modes

- Amount of time (effort) spent by ETCs

- Organizational culture: relating commuting with health and wellness

- Regular reminders to employees of program offerings and benefits but not so frequently that employees begin to ignore the information

Numerous external factors contributed to worksite trip reduction program success as listed below in roughly an order of most to least important.

\subsubsection{External factors:}

- Trip reduction ordinance

- Good transit service and transit agencies willing to meet worksite scheduling needs

- Traffic congestion that makes fixed guideway transit service and HOV lanes more time competitive

- $\quad$ Limited public parking

- Gas price increases affected mode share especially for employees with lower wages and for suburban and rural worksites

- Outside Assistance such as ETC networking and training through lunch workshops, ready-made regional marketing campaigns help keep cost of employer-based CTR program lower, and an online commute calendar that the worksite ETCs can use to track employee travel behavior for purposes of reporting and distributing subsidies and incentives

\subsection{Direction for Future Research}

The nature of a business is motivated by reducing costs and increasing profits. While the nature of a business is ultimately controlled by management, altering it to accommodate the needs of a trip reduction program may entail costs. It may put management in a position of having to compromise maximizing profits and minimizing costs for the sake of the trip reduction program. Businesses are not likely to do that unless under regulatory requirements. Under a regulatory trip reduction environment, it is anticipated that management support will overcome problems relating to the nature of the business. Under a voluntary trip reduction environment, it is anticipated that management will not likely overcome problems relating to the nature of the business. For future research, it is hypothesized that under a voluntary environment, the nature of the business has more influence upon the success of a worksite trip reduction program than management support. 
Appendices 
Appendix A: Case Studies

Acordia Northwest, Inc.

Alsco

Eastern State Hospital

Evergreen State College

Mercer Human Resource Consulting

Microsoft Corporation

Pine Lodge Women's Correctional Facility

St. Joseph's Hospital

South Seattle Community College (SSCC), West Seattle Campus

Tacoma Public Utilities

Virginia Mason Medical Center

Weyerhaeuser Company 
Acordia Northwest, Inc.

Seattle, Washington

\section{Keys to Success}

Located in the heart of downtown Seattle, Acordia Northwest, Inc. (worksite hereinafter referred to as Acordia) has excellent access to superior transit and ferry service that is timely, comfortable and provides extras, such as dining and a social atmosphere. The worksite offers supportive amenities and subsidized Flexpasses. The work conducted is on a predictable daily schedule, making transit more easily available. It is expensive to commute into the downtown area and even more expensive to park on-site ( $\$ 28$ per day). Acordia does not subsidize parking and the drivealone commute is more time consuming to some commuters than riding transit.

\section{Results and Cost}

Acordia was a Commuter Challenge Diamond Award winner in 1999 and Vehicle Miles Traveled (VMT) and Single Occupant Vehicles (SOV) have continued to decrease since then. As a result of Acordia's Commute Trip Reduction (CTR) program, the drive alone rate decreased from 42.1 percent in 1993 to 9.3 percent in 2003. Public transit increased from 34.7 percent to 68.6 percent. Carpooling stayed about the same during this time at just over 18 percent. Vanpooling is now used by 2 percent of the affected employees. Last year, it cost Acordia Northwest $\$ 56,000$ for the CTR Program, which includes just the Flexpasses. The core of the CTR Program is the purchase and distribution of the Flexpasses.

\section{Organizational Culture}

Acordia is an insurance brokerage, owned by Wells Fargo and located in the downtown central business district of Seattle, Washington. According to the Employee Transportation Coordinator (ETC), the core corporate value is to give the customer the best insurance policy for the least amount of money and then follow up with customer care. Because of the central location, customers can easily find their office. Employees work during a single daytime shift to make themselves most accessible to clients. The worksite started out as a small company that has since been acquired by another firm, but the worksite remained in the same place. The company has been at its present location for the past 50 years. Acordia was required to participate in the Washington State Commute Trip Reduction Program until recently. Acordia's participation is presently voluntary. The worksite's dress code is described as business casual. Acordia employees are active in charitable work, such as Habitat for Humanity.

The CTR program was described by the Employee Transportation Coordinator as not necessarily aligned with the business mission of Acordia, nor as a program which provides business benefits. The ETC preferred to describe the CTR Program as "Just a nice way to take care of the employees and help them out." The ETC says that the views of top management and her immediate supervisor are aligned with regard to the value of the CTR program. Her immediate supervisor uses the Flexpass to commute. The ETC said that management does not have greater expectations for any group of employees or job type to use alternative transportation modes more frequently. 


\section{Acordia Northwest, Inc.}

Seattle, Washington

\section{External Conditions}

Traffic conditions surrounding the worksite are described by the ETC as actually very good during peak commute times unless there is a special event downtown. She perceived traffic conditions as remaining generally the same over the past year. The ETC said that other employers seeking downtown office space comparable to Acordia's would not find it difficult to locate office space with similar amenities for a reasonable price. She said that there have been many tenants that have come and gone in their building in the last 10 years. The ETC says there is presently a high occupancy rate of office downtown space. There are no known issues about transportation that relate the Acordia worksite to surrounding employers. The ETC says that employees are satisfied with bus service. Transit "...runs every ten minutes all over the place" during the peak hours and during the remainder of the day, one can always find a bus. She says "They run North, South, East and West and there is always a park-and-ride."

\section{On-Site Amenities}

The company is on the 20th floor and shares the building with other employers. As a result of being a long-time lessee, the company gets a good deal on downtown office space rent and the amenities associated with the building. Their office space rental contract is negotiable and Acordia has a good rapport with the building manager. She said that their office building is one of the older buildings in the downtown that has been refurbished. There is a bus stop within three blocks of the worksite arriving about every 10 minutes during peak commuting hours. There are also restaurants, shopping and banking within one quarter mile of the worksite and an on-site lunch room that overlooks the water. There are sidewalks onsite, as well as both uncovered and covered free bicycle parking in the garage. The building also offers a free gym, clothes lockers and showers to all building employees and a loading/unloading shelter for high occupancy vehicles.

\section{Employee Characteristics}

As of 2005, Acordia employed 170 people and 120 employees were affected by the Washington State CTR Law. However, Acordia now employs approximately 140 employees, over 40 of which are producers (salespeople) who must travel during the day to meet clients. Acordia pays for their parking. Employees arrive between 7-9 a.m. and leave between 3:30 and 5:30 p.m. This is an 8:30-4:30 office and no one works on flextime or teleworks. The nature of the work requires employees to come into the office and be there at specific times to be available to clients. Employees are all full time and described as a highly skilled professional workforce, representing a wide range of job classifications. The office has different departments by type of insurance, including property, casualty, health, aviation and marine. Within each department, there are different types of professionals, including account administrators and account managers. Many employees bring their lunch because it is expensive to eat downtown. In their building, it costs $\$ 28$ per day to park. 


\section{Acordia Northwest, Inc.}

Seattle, Washington

Commute Trip Reduction Program

Acordia offers to all CTR-affected employees annual Flexpasses good on Metro, Sound Transit and Sounder. Employees are charged $\$ 5.00$ per pay period, or $\$ 130$ per year for the Flexpass. Most employees drive from home to a park-and-ride lot where they access transit. If they link trips, they run errands after they get off transit in the evening and find their cars. Employees wanting a Puget Pass are provided a $\$ 30$ per month subsidy. CTR-affected employees who commute using the ferry receive $\$ 30$ per month in commuter bonus vouchers. Acordia previously leased 35 on-site parking spaces for $\$ 235$ per month and leased 13 off-site spaces for $\$ 185-230$ per month. After 2001, no parking was leased. The building provides garage parking for employees but anyone who wants to use parking pays $\$ 260$ per month per space. Each employee who vanpools receives a $\$ 55$ subsidy per month. A guaranteed ride home program is also offered. CTR Program promotion activities include distributing CTR program summaries to employees, providing information to new employees, and giving presentations to employees.

The ETC said that when she distributes Flexpasses at the beginning of each year, she is " $\ldots$ the most liked person in the office." It is very expensive to commute into the city. The ETC said that employees appreciate the cost savings of the Flexpass provided by Acordia-they consider the subsidized Flexpass a "treasure." The ETC rides both the train and the bus for $\$ 10$ per month and she notes that others who do not work at Acordia are impressed because they do not have that financial incentive. When people first begin to work at Acordia, the reaction from new employees about the Flexpass subsidy is "This is awesome!" Last year, she ran out of the Flexpasses and had to order more. Acordia has not increased the price of the employee contribution, nor does the ETC think Acordia intends to in the near future.

Commuting from the outlying suburbs into the downtown is generally time consuming. The ETC describes her own commute: it would take her 90 minutes to drive from home to work downtown whereas the train ride is 40 minutes. She said, "If I had to drive to downtown Seattle, I probably wouldn't be working here." The combination bus and train rides get her to work on time and she does not have to worry about car maintenance. The buses are comfortable, heated in the winter and air conditioned in the summer. The longest part of her commute is on the train. She says people spend their time on the train drinking coffee, eating, talking, visiting, and sleeping. She used the terms "bonding with friends" and "...taking care of each other." She previously rode the ferry and described the experience as pleasant because there was a galley where coffee and breakfast are served in the morning and wine is served in the evening. The ETC said that occasionally someone will decide to start driving to and from work but within a few weeks they return to the ETC and ask for a Flexpass again. 


\section{Acordia Northwest, Inc.}

Seattle, Washington

\section{Employee Transportation Coordinator}

The ETC for Acordia has held this position for four years and has completed an ETC training class. She spends on average 2 hours per week on ETC duties and does not need additional help from other employees. She does not use outside sources of support for the CTR program. The ETC is the Executive Assistant and her position is in the Administrative department. The job title by which employees know her is "Ex. Assistant or ask [her and] she will find the answer!!" The ETC does not have a separate office. She was assigned the duties of ETC and her ETC duties are not part of her written job description. The ETC is occasionally asked her opinion about program operations but program decisions are made by her supervisor. The ETC's position with respect to the organizational hierarchy includes the ETC's direct supervisor who reports to the managing director. The ETC cites advantages of her duties as an ETC, including opportunities to get to know all the employees, especially during survey time. The ETC said that if she had to drive in order to go to work at Acordia, she probably would not be working there.

The ETC describes her ETC duties as not requiring much effort and the easiest part of her job. The CTR Program benefits essentially sell themselves. The ETC has not found the need to do any promotions because she says the employees know what they need to know. The ETC thinks that the Flexpass benefit is probably a more appreciated benefit to the employees than their health plan. She has a good rapport with the Metro liaison; she has always gotten the information she needs. 


\section{Organization Information (2005)}

\section{Acordia Northwest, Inc}

Seattle, WA

Website:

www.acordia.com

Primary Business:

Non-profit organization?

Finance, Insurance,

Total Employees:

No

Affected Employees:

Is the CTR program subject to collective bargaining? No

Does this worksite have multiple shifts?

No

Shifts description:

$\mathrm{N} / \mathrm{A}$

\section{CTR program contact:}

David Lantry

King County Metro

400 Yesler Way, MS YES-TR-0650, Seattle, WA 98104

Phone: (206) 684-1139

Email: david.lantry@metrokc.gov

\section{Worksite Characteristics (2005)}

$\begin{array}{cccccc}\text { Bus stop(s) } & \text { Bike lane } & \text { Sidewalks } & \text { Restaurants } & \text { Shopping } & \text { Bank } \\ \text { Availability } & \text { Availability } & \text { Availability } & \text { Availability } & \text { Availability } & \text { Availability } \\ \text { Within } 1 / 4 \text { mile } & \text { Not available } & \text { Onsite } & \text { Within } 1 / 4 \text { mile Within } 1 / 4 \text { mile Within } 1 / 4 \text { mile }\end{array}$

\section{Program Narrative (2001)}

We provide annual Flexpasses (metro, sound \& sounder) to all CTR affected employees. They are charged $\$ 5$ per pay period, or $\$ 130 /$ year, for the Flexpass. Employees wanting a Puget pass must purchase the pass directly from community transit. We then will provide those employees with a $\$ 30$ per month subsidy. CTR affected employees who commute via ferry are provided with $\$ 30$ per month in commuter bonus vouchers.

\section{Worksite Parking and Parking Management Information}

\section{Parking management and monitoring (2005)}

The garage provides parking for the company, but anyone who uses spaces must pay.

\section{Parking}

$\begin{array}{ccccc}\begin{array}{c}\text { Program } \\ \text { Year }\end{array} & \begin{array}{c}\text { Total Num of } \\ \text { Employees }\end{array} & \begin{array}{c}\text { Onsite Parking } \\ \text { Spaces }\end{array} & \begin{array}{c}\text { Offsite Parking } \\ \text { Spaces }\end{array} & \begin{array}{c}\text { Leased Onsite } \\ \text { Parking Spaces }\end{array} \\ 1999 & 171 & 25 & 27 & 25 \\ 2001 & 163 & 35 & 13 & 35 \\ 2003 & 171 & 0 & & 0 \\ 2005 & 170 & 0 & 0 \\ \text { Program } & \text { Leased Offsite } & \text { Leased Onsite Parking } & \text { Leased Offsite Parking } \\ \text { Year } & \text { Parking Spaces } & \text { Price (Space/Month) } & \text { Price (Space/Month) } \\ 1999 & 27 & \$ 200 & \$ 195 \\ 2001 & 13 & \$ 235 & \$ 185-\$ 230 \\ 2003 & & & \end{array}$




\section{Parking management}

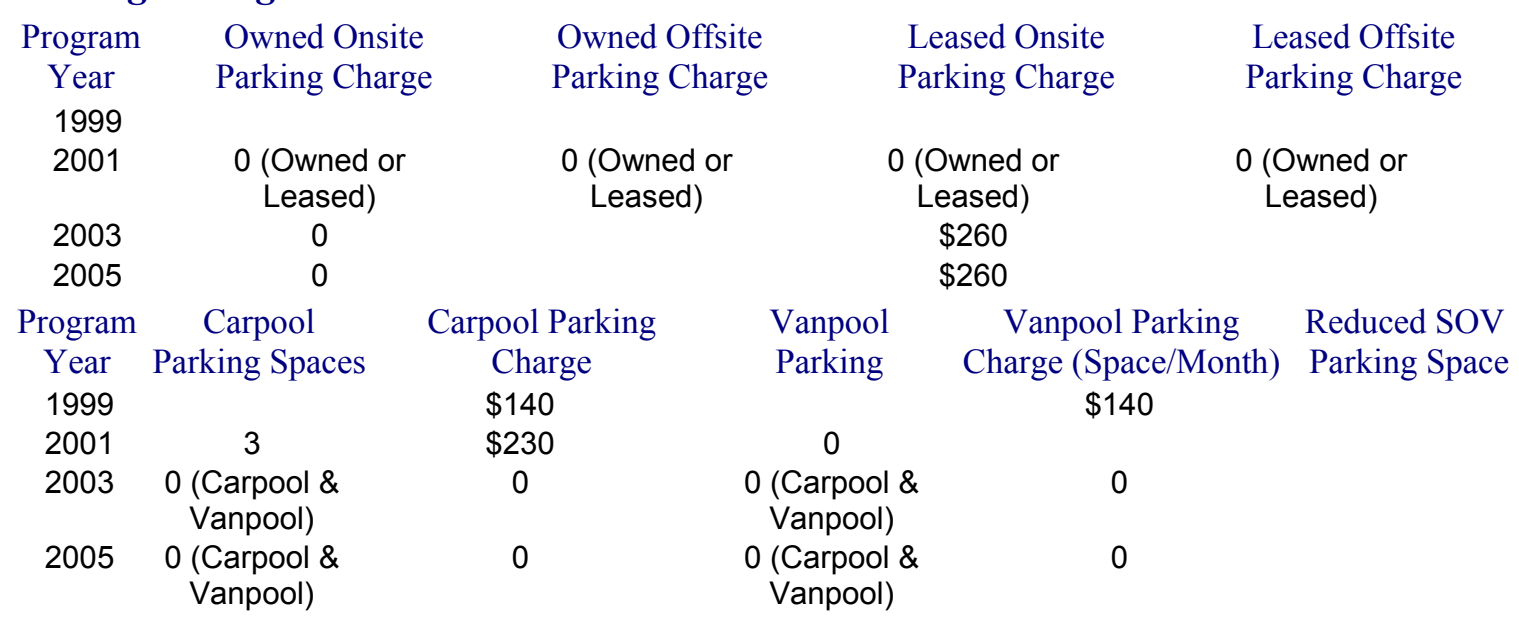

\section{Program Promotion}

General (2005)

Is the ETC's name, location and telephone number prominently displayed at this Yes

Displayed where? 20th Floor / Lunch Room

Has the ETC completed a program developer/ETC training course?

On average, how many hours per week does the ETC spend on CTR activities? 2

Does the ETC have an active worksite committee to assist with the CTR No

\section{Program promotion}

\begin{tabular}{|c|c|c|c|c|c|c|}
\hline \multirow{2}{*}{$\begin{array}{c}\text { Program } \\
\text { Year }\end{array}$} & Distribute & \multicolumn{3}{|c|}{ Provide CTR Program } & \multirow{2}{*}{$\begin{array}{c}\text { Post } \\
\text { Materials }\end{array}$} & \multirow{2}{*}{$\begin{array}{l}\text { Give Managers } \\
\text { Presentation }\end{array}$} \\
\hline & Summary of & Inforr & ation to New $\mathrm{E}$ & aployees & & \\
\hline 1999 & Yes & & Yes & & No & No \\
\hline 2001 & Yes & & Yes & & Yes & Yes \\
\hline 2003 & Yes & & Yes & & Yes & No \\
\hline 2005 & Yes & & Yes & & Yes & No \\
\hline Program & Give & Conduct & Publish & Dist & bute & Distribute \\
\hline Year & Employees & CTR Events & CTR Articles & Informa & on with & Ridematch \\
\hline 1999 & No & No & & $\mathrm{Nc}$ & & Yes \\
\hline 2001 & Yes & No & No & No & & No \\
\hline 2003 & Yes & No & No & No & & No \\
\hline 2005 & Yes & No & No & No & & No \\
\hline
\end{tabular}

\section{Site Amenities}

$\begin{array}{cccccc}\begin{array}{c}\text { Program } \\ \text { Year }\end{array} & \begin{array}{c}\text { Covered } \\ \text { Bicycle Spaces }\end{array} & \begin{array}{c}\text { Uncovered } \\ \text { Bicycle Spaces }\end{array} & \begin{array}{c}\text { Clothes } \\ \text { Lockers }\end{array} & \text { Showers } & \text { Non-SOV On-site } \\ 1999 & \text { Yes } & \text { No } & \text { No } & \text { Yes } & \text { Loading/Unloading } \\ 2001 & \text { Yes } & \text { Yes } & \text { Yes } & \text { Yes } & \text { Yes } \\ 2003 & \text { Yes } & \text { Yes } & \text { Yes } & \text { Yes } & \text { No } \\ 2005 & \text { Yes } & \text { Yes } & \text { Yes } & \text { Yes } & \text { Yes }\end{array}$




\section{Financial Subsidies, Incentives or Allowances}

$\begin{array}{ccccc}\begin{array}{c}\text { Program } \\ \text { Year }\end{array} & \begin{array}{c}\text { Transit Subsidy } \\ \text { (Employee/Month) }\end{array} & \begin{array}{c}\text { Vanpool Subsidy } \\ \text { (Employee/Month) }\end{array} & \begin{array}{c}\text { Carpool Subsidy } \\ \text { (Employee/Month) }\end{array} & \begin{array}{c}\text { Walking Subsidy } \\ \text { (Employee/Month) }\end{array} \\ 1999 & \text { Free FlexPass } & 0 & \$ 30 & 0 \\ 2001 & \$ 30 & 0 & \$ 30 & 0 \\ 2003 & \$ 30 & \$ 55 & 0 & 0 \\ 2005 & \$ 30 & \$ 55 & 0 & 0 \\ \text { Program } & \text { Ferry Subsidy } & \text { Bicycling Subsidy } & \text { Other Stipend } & \\ \text { Year } & \text { (Employee/Month) } & \text { (Employee/Month } & \text { (Employee/Month) } \\ 1999 & \$ 30 & 0 & 0 & \\ 2001 & \$ 30 & 0 & 0 & \\ 2003 & \$ 30 & 0 & 0 & \\ 2005 & \$ 30 & 0 & 0 & \end{array}$

\section{Fleet Vehicles and Special Programs}

\section{Employer provided vehicles availability}

$\begin{array}{cccccc}\begin{array}{c}\text { Program } \\ \text { Year }\end{array} & \begin{array}{c}\text { FV Guaranteed } \\ \text { Ride Home }\end{array} & \text { FV Vanpool } & \begin{array}{c}\text { FV } \\ \text { Carpool }\end{array} & \begin{array}{c}\text { FV Work- } \\ \text { Related Trips }\end{array} & \begin{array}{c}\text { FV Non-Work } \\ \text { Related Errands }\end{array} \\ 1999 & \text { No } & \text { No } & \text { No } & \text { No } & \text { No } \\ 2001 & \text { No } & \text { No } & \text { No } & \text { No } & \text { No } \\ 2003 & \text { No } & \text { No } & \text { No } & \text { No } & \text { No } \\ 2005 & \text { No } & \text { No } & \text { No } & \text { No } & \text { No }\end{array}$

\section{Other services availability}

$\begin{array}{cccc}\text { Program } & \text { Employer-Provided } & \text { Guaranteed Ride Home } & \text { Internal Match } \\ \text { Year } & \text { Shuttle } & \text { Program } & \text { Program } \\ 1999 & \text { No } & \text { Yes } & \\ 2001 & \text { No } & \text { Yes } & \\ 2003 & \text { No } & \text { Yes } & \text { No } \\ 2005 & \text { No } & \text { Yes } & \text { No }\end{array}$

\section{Mode Split and Vehicle Miles Traveled}

\begin{tabular}{|c|c|c|c|c|c|c|c|}
\hline $\begin{array}{l}\text { Program } \\
\text { Year }\end{array}$ & \multicolumn{2}{|c|}{$\begin{array}{l}\text { Num of Surveys } \\
\text { Distributed (Num of }\end{array}$} & \multicolumn{2}{|c|}{ Total Reported } & $\begin{array}{l}\text { Driving } \\
\text { Alone }\end{array}$ & Carpooling & Vanpooling \\
\hline 1993 & 163 & & 747 & & $42.1687 \%$ & $18.8755 \%$ & $0.0000 \%$ \\
\hline 1995 & 118 & & 554 & & $41.5162 \%$ & $20.9386 \%$ & $0.0000 \%$ \\
\hline 1997 & 110 & & 515 & & $24.8544 \%$ & $28.9320 \%$ & $0.0000 \%$ \\
\hline 1999 & 112 & & 531 & & $15.8192 \%$ & $21.4689 \%$ & $0.0000 \%$ \\
\hline 2001 & 115 & & 541 & & $13.3087 \%$ & $15.5268 \%$ & $0.0000 \%$ \\
\hline 2003 & 112 & & 458 & & $9.3886 \%$ & $18.5590 \%$ & $2.1834 \%$ \\
\hline Program & Public & Bicycling & Walking & Other & & hicle Miles & \\
\hline Year & Transit & & & & & Traveled & \\
\hline 1993 & $34.6720 \%$ & $0.2677 \%$ & $2.6774 \%$ & 1.3387 & & 7.64 & \\
\hline 1995 & $32.4910 \%$ & $0.0000 \%$ & $4.1516 \%$ & 0.9025 & & 7.89 & \\
\hline 1997 & $40.1942 \%$ & $0.0000 \%$ & $5.0485 \%$ & 0.9709 & & 5.44 & \\
\hline 1999 & $56.3089 \%$ & $0.0000 \%$ & $6.0264 \%$ & 0.3766 & & 3.43 & \\
\hline 2001 & $70.0555 \%$ & $0.0000 \%$ & $0.0000 \%$ & 1.1091 & & 3.48 & \\
\hline 2003 & $68.5590 \%$ & $0.0000 \%$ & $1.0917 \%$ & 0.2183 & & 2.72 & \\
\hline
\end{tabular}




\section{Compressed Work Week, Flex Time and Teleworking}

Policy (2001)

Flex Time

Employees are scheduled to work a 7.5 hour day. Employees arrive anywhere between 7 and 9 am and leave between 3:30 and 5:30 pm

Teleworking

\section{Percentage of employees on Compressed Work}

\begin{tabular}{ccccc}
$\begin{array}{c}\text { Program } \\
\text { Year }\end{array}$ & $\begin{array}{c}\text { Num of Surveys } \\
\text { Distributed (Affected }\end{array}$ & $\begin{array}{c}\text { Total Surveys } \\
\text { Reported }\end{array}$ & $\begin{array}{c}\text { Percentage of Employees } \\
\text { On 5 Days/Week }\end{array}$ & $\begin{array}{c}\text { Percentage of Employees } \\
\text { On 3 Days/Week }\end{array}$ \\
1993 & 163 & 154 & $96.7532 \%$ & $0.6494 \%$ \\
1995 & 118 & 115 & $97.3913 \%$ & $0.0000 \%$ \\
1997 & 110 & 107 & $97.1963 \%$ & $0.0000 \%$ \\
1999 & 112 & 107 & $97.1963 \%$ & $0.0000 \%$ \\
2001 & 115 & 110 & $98.1818 \%$ & $0.9091 \%$ \\
2003 & 112 & 93 & $96.7742 \%$ & $0.0000 \%$ \\
Program & Percentage of Employees & Percentage of Employees & Percentage of Employees \\
Year & On 4 Days/Week & On 7 Days/Two Weeks & On 9 Days/Two Weeks \\
1993 & $1.9481 \%$ & \multicolumn{2}{c}{$0.0000 \%$} & $0.0000 \%$ \\
1995 & $1.7391 \%$ & \multicolumn{2}{c}{$0.0000 \%$} & $0.0000 \%$ \\
1997 & $1.8692 \%$ & \multicolumn{2}{c}{$0.0000 \%$} & $0.9346 \%$ \\
1999 & $0.9346 \%$ & \multicolumn{2}{c}{$0.0000 \%$} & $0.9346 \%$ \\
2001 & $0.9091 \%$ & \multicolumn{2}{c}{$0.0000 \%$} & $0.0000 \%$ \\
2003 & $2.1505 \%$ & $0.0000 \%$ & $0.0000 \%$
\end{tabular}

\section{Percentage of employees on Telecommuting}

\begin{tabular}{|c|c|c|c|c|c|}
\hline $\begin{array}{l}\text { Program } \\
\text { Year }\end{array}$ & \multicolumn{2}{|c|}{$\begin{array}{l}\text { Num of Surveys Distributed } \\
\text { (Num of Affected Employees) }\end{array}$} & $\begin{array}{l}\text { Total Surveys } \\
\text { Reported }\end{array}$ & $\begin{array}{l}\text { Total Percentage } \\
\text { of Telecommuters }\end{array}$ & $\begin{array}{l}1 \text { Days every } \\
\text { Two Weeks }\end{array}$ \\
\hline 1993 & \multicolumn{2}{|c|}{163} & 154 & $4.5455 \%$ & $0.6494 \%$ \\
\hline 1995 & \multicolumn{2}{|c|}{118} & 115 & $4.3478 \%$ & $0.0000 \%$ \\
\hline 1997 & \multicolumn{2}{|c|}{110} & 108 & $0.9259 \%$ & $0.0000 \%$ \\
\hline 1999 & \multicolumn{2}{|c|}{112} & 108 & $0.0000 \%$ & $0.0000 \%$ \\
\hline 2001 & \multicolumn{2}{|c|}{115} & 110 & $1.8182 \%$ & $0.0000 \%$ \\
\hline 2003 & \multicolumn{2}{|c|}{112} & 89 & $0.0000 \%$ & $0.0000 \%$ \\
\hline Program & 2 Days every & 3 Days & 4 Days every & 5 Days every & More than 5 \\
\hline Year & Two Weeks & every Two & Two Weeks & Two Weeks & Days every Two \\
\hline 1993 & $0.6494 \%$ & $1.2987 \%$ & $1.2987 \%$ & $0.6494 \%$ & $0.0000 \%$ \\
\hline 1995 & $1.7391 \%$ & $0.0000 \%$ & $0.8696 \%$ & $0.8696 \%$ & $0.8696 \%$ \\
\hline 1997 & $0.0000 \%$ & $0.0000 \%$ & $0.0000 \%$ & $0.0000 \%$ & $0.9259 \%$ \\
\hline 1999 & $0.0000 \%$ & $0.0000 \%$ & $0.0000 \%$ & $0.0000 \%$ & $0.0000 \%$ \\
\hline 2001 & $0.9091 \%$ & $0.0000 \%$ & $0.9091 \%$ & $0.0000 \%$ & $0.0000 \%$ \\
\hline 2003 & $0.0000 \%$ & $0.0000 \%$ & $0.0000 \%$ & $0.0000 \%$ & $0.0000 \%$ \\
\hline
\end{tabular}




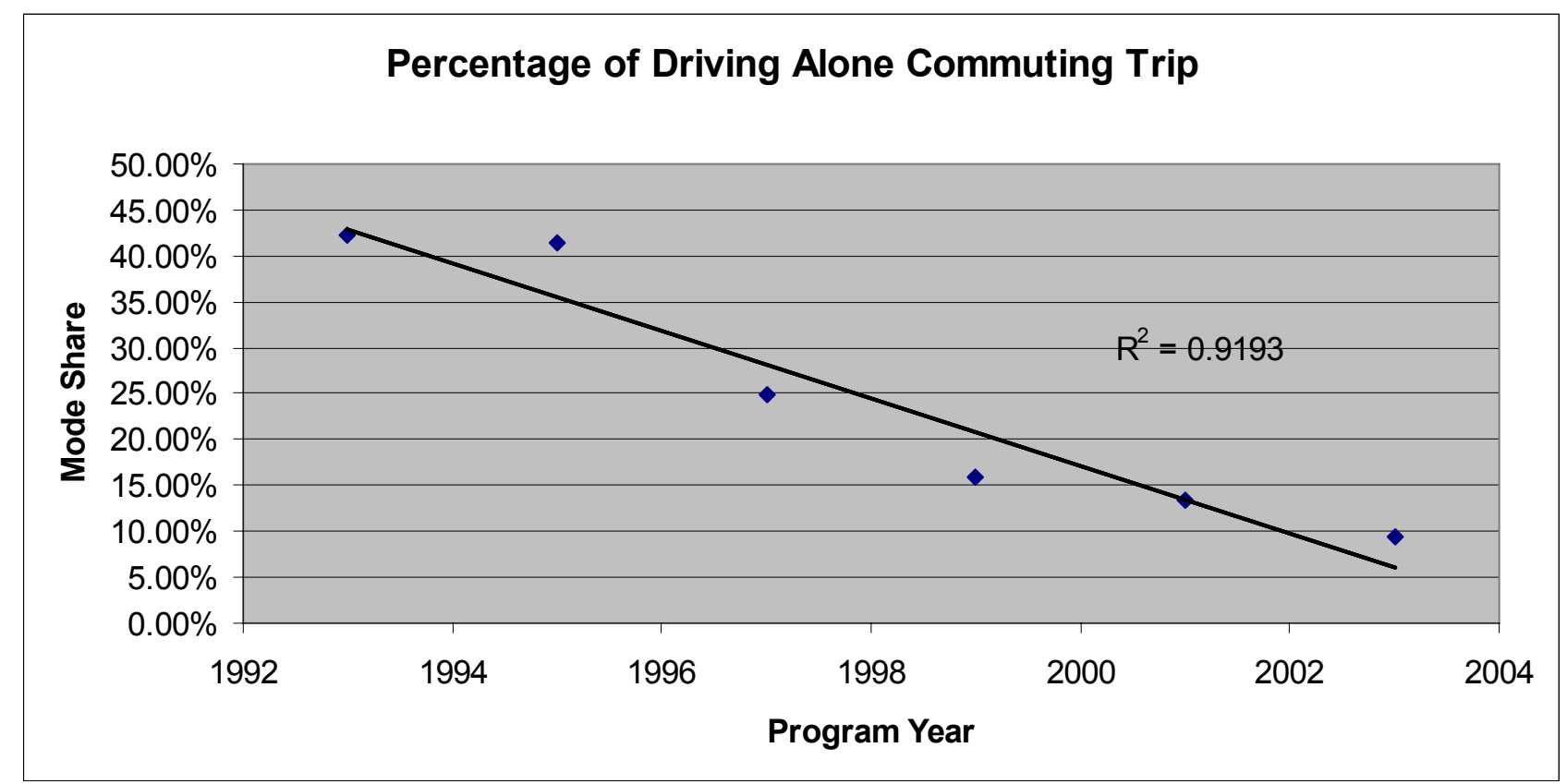

Figure 1: Percentage of Drive-Alone Commute Trips - Acordia Northwest

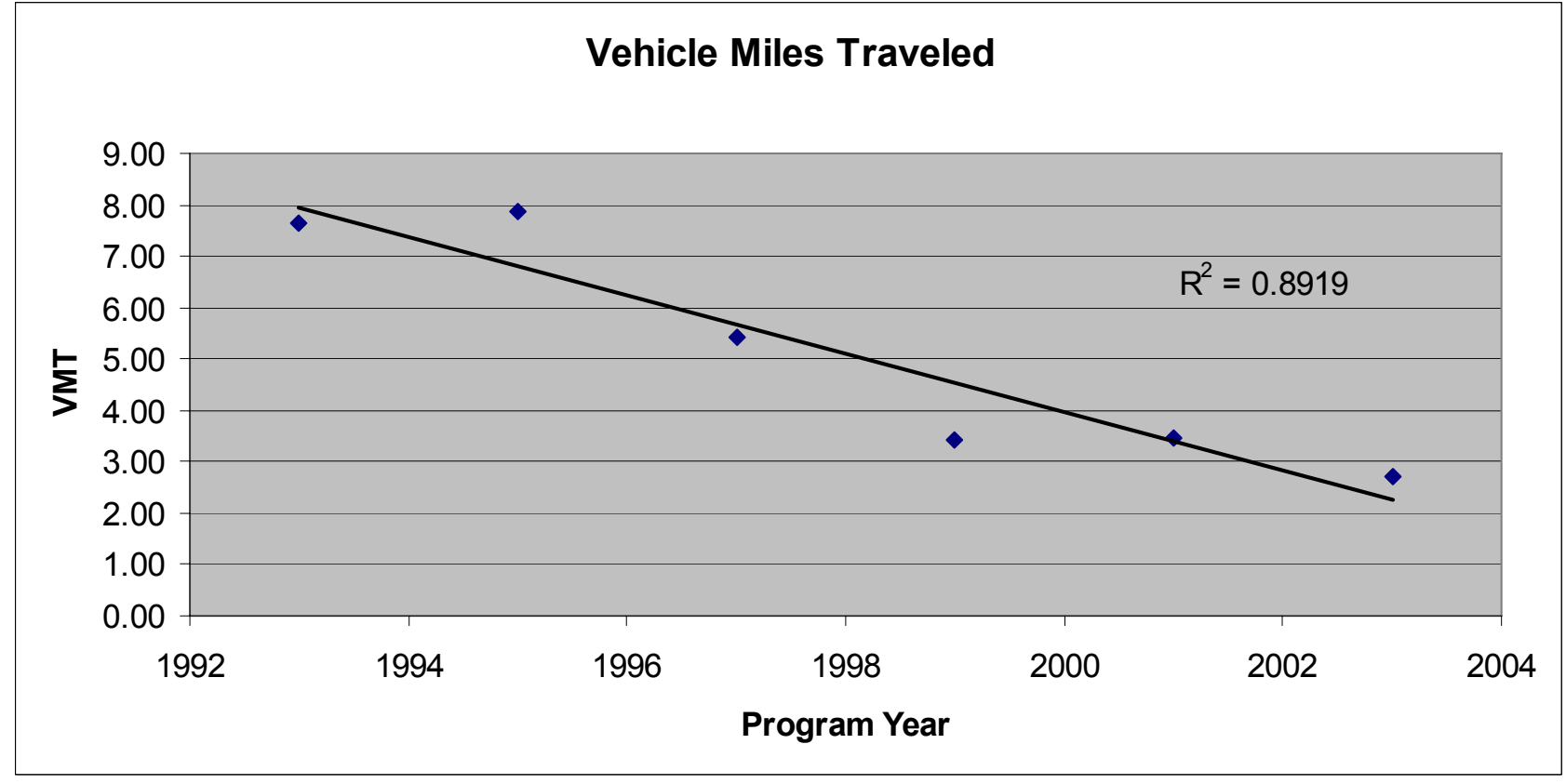

Figure 2: VMT - Acordia Northwest 


\section{Alsco}

Spokane, WA

\section{Keys to Success}

Alsco of Spokane, Washington is a part of a world-wide linen rental company with approximately 160 employees. The cost savings of carpooling for the high number of low-wage, entry level workers is seen as a significant factor in the success of their commute trip reduction (CTR) program. Another factor is the effort put forth by the employee transportation coordinator (ETC), in communicating the benefits of ridesharing and his ability to find carpool partners for his co-workers through an internal ridematching system. One factor of Alsco's success that stands out is related to its ethnically diverse employee population, many of whom are recent immigrants to the United States. The ETC believes that the various cultures of these employees place a high value on saving money and that they "have not been Americanized enough to believe that everyone needs their own car."

\section{CTR Program Elements}

- Internal ridematching system

- $\$ 5$ per month transit subsidy

- Bicycle parking

- Employee lockers and showers

- Employee Transportation Coordinator

\section{Results and Costs}

Between 1995 and 2003, Washington State DOT survey data indicate that Alsco's drive-alone mode share has decreased from 76.9 percent to 66.2 percent. By October of 2006, the drive alone mode share stands at only 35 percent. This dramatic change is believed to be related to the increase in gas prices. Between 1995 and 2003, the average one way vehicle miles traveled (VMT) per employee has decreased from 9.48 VMT to 7.92 VMT. According to the 2003 Washington State DOT data, approximately 28.9 percent of their 180 employees carpooled to work and another 4.7 percent used public transit. By 2006, the carpooling mode share has nearly doubled.

The ETC estimates that Spokane Alsco worksite spends $\$ 6,000$ per year in labor and incentives maintaining the CTR program. Incentives are primarily gift certificates distributed through random drawings of alternative mode users. 


\section{Alsco}

Spokane, WA

\section{External Factors}

While access to high quality transit is typically a characteristic of successful employer CTR programs, Alsco's suburban worksite is not well served. The nearest transit stop is between a quarter and half mile away, and service is infrequent. According to the ETC, buses "come every hour, so its one shot on one bus that they have to come down here to make it on time, and many have to make a connection downtown to get on that bus to make it out." Another barrier is that transit users must cross a busy highway to access the worksite. As a result, the only employees that use transit are ones that do not have a car or cannot find a carpool to join. Without access to high quality transit, Alsco employees depend primarily on carpooling.

Alsco's CTR Program is successful despite not having any of the usual parking shortages or traffic congestion issues. Furthermore, the surrounding area does not provide opportunities to run errands. This condition can sometimes push employees to drive alone since any errands would require traveling a significant distance.

An external factor that does contribute directly to the program's success is participation in the regional ETC network functions. The County's CTR program hosts networking luncheons on a monthly basis so that ETCs from different worksites can share ideas, problems and solutions. The network luncheons also serve to distribute promotional materials on the regional and statewide marketing campaigns. The ETC credits the County with creating a program that saves him time and effort:

Our county has a formalized program and they have applied for and gotten grants so that they have money to use to hold campaigns about 5 to 6 times a year, which helps us promote our programs. It's a very active part of our program here, as it piggybacks on all the County programs. They also provide some prizes and printed up flyers... its kind of a canned campaign that comes to me that does not require a lot of smarts or energy, and it saves me a lot of time.

For him, the ETC luncheons have been critical to his ability to communicate the benefits of ridesharing and provide innovative ways to market the program to his co-workers.

I like to network with the other ETCs from other businesses and the luncheons that we do and we can sit down and talk about what we do and what works for them and what works for me, and get different ideas...I find that that really helps. During different campaigns I have used different types of strategies picked up at the ETC luncheons to get people's interests, for example we had a poker run contest, and we would hand out cards to each person that rideshares each day and the best hand would win a grand prize at the end of the week.

His satisfaction with the County's efforts is magnified when he talks with other Alsco branches in Oregon and California that don't even know what he is talking about. 


\section{Alsco}

Spokane, WA

Another external factor that has contributed to the success of Alsco's CTR program is the increase in the price of gas in the last few years. As the price of gas began to increase, the ETC saw an increased demand for his services as an ETC.

\section{Internal Factors}

The impact that higher gas prices had on their program is related to the nature of the business and the high percent of low-wage, entry level workers. The ETC knows that the primary reason for using an alternative mode, primarily carpooling in this case, is financial. The economic situation of many of their employees is also represented by a low rate of car ownership. Without access to high quality transit or a private automobile, the production workers, as they are called, rely on carpooling with co-workers and often family members.

The production workers come from a wide variety of ethnic groups, with many being recent immigrants to the United States. When asked about Alsco's corporate culture, the ETC responded:

We don't have our own culture, we have many. We have 90 of our 160 employees that work down in our production area, and they are Asian, Russian, Hispanic, a lot of other ethnic backgrounds, and new immigrants as well. These are kind of entry-level jobs, we are not like a Microsoft where everyone wears their polo shirt and khakis to work and bangs on a keyboard... there is a lot of diversity here.

While there is a lot of diversity, the production workers all feel the financial constraints of commuting and as the ETC put it, "They have not been Americanized enough to believe that everyone needs their own car."

The ETC credits the support he receives from upper management for the success of the program. Alsco spends approximately $\$ 6,000$ a year on their CTR program in the form of the ETC's labor time and incentives for alternative mode users. He also likes the fact that he is empowered to initiate new ideas and communication techniques without micro-management from above.

Another reason for their success is the experience and knowledge acquired by the ETC, who has served in this capacity for the last 14 years. His advice to new ETCs is:

They would need to do an evaluation on their business and find out what would work best for their scenario, whether it would be carpooling or light rail or whatever... to figure out what employees need. It's just like trying to sell something; you need to find the need.

The ETC estimates that he spends approximately $10 \%$ of his time administering the awardwinning CTR program. When he is not doing that, he serves as human resources manager and service representative to local hospitals. 
Organization Information (2004)

\section{Alsco}

Spokane, WA

Website:

www.alsco.com

Primary Business:

Professional/Personal

Non-profit organization?

No

Total Employees:

180

Affected Employees:

160

Is the CTR program subject to collective bargaining? Yes

Does this worksite have multiple shifts? Yes

Shifts description:

Soil area 6:00am - 2:30pm, Production 7:00am - 3:30pm, Drivers starts vary from

2:00am - 8:00am.

\section{CTR program contact:}

Aurora Crooks

TDM Manager, Spokane County CTR Office

1026 W Broadway Ave., Spokane, WA 99260

Phone: 509-477-7540

Email: acrooks@spokanecounty.org

\section{Worksite Characteristics (2004)}

$\begin{array}{cccccc}\text { Bus stop(s) } & \text { Bike lane } & \text { Sidewalks } & \text { Restaurants } & \text { Shopping } & \text { Bank } \\ \text { Availability } & \text { Availability } & \text { Availability } & \text { Availability } & \text { Availability } & \text { Availability } \\ \text { Within } 1 / 4 \text { mile } & \text { Not available } & \text { Not available } & \text { Onsite } & \text { Not available } & \text { Not available }\end{array}$

Program Narrative (2000)

1. Subsidy of $\$ 5.00$ on monthly bus pass. 2. Company vehicles for work related business trips. 3 . Ride share matching. 4. Guaranteed ride home. 5. Bicycle parking. 6. Employee lockers \& showers. 7. Employee cafeteria \& mobile catering. 8. CTR Information Center. 9. CTR Information to all new hires. 10. Four yearly promotions of CTR Program to all employees.

\section{Worksite Parking and Parking Management Information \\ Parking management and monitoring (2004)}

Parking is on a first come basis.

\section{Parking}

Program

Year

1999

2000

2002

2003

2004

Total Num of
Employees
207
207
195
180
180

Onsite Parking

Spaces

103

103

103

103

Program Leased Offsite

103

Year

Parking Spaces

Leased Onsite Parking

Offsite Parking

Leased Onsite

Spaces

Parking Spaces

1999

2000

2002

2003

2004

0
0
0
0
0

0
0
0
0
0

Leased Offsite Parking

Price (Space/Month) 


\section{Parking management}

\begin{tabular}{|c|c|c|c|c|c|}
\hline Program & Owned Onsite & Owned Offsite & & Leased Onsite & Leased Offsite \\
\hline Year & Parking Charge & Parking Charge & & Parking Charge & Parking Charge \\
\hline 1999 & $\begin{array}{c}0 \text { (Owned or } \\
\text { Leased) }\end{array}$ & $\begin{array}{l}0 \text { (Owned or } \\
\text { Leased) }\end{array}$ & & $\begin{array}{l}0 \text { (Owned or } \\
\text { Leased) }\end{array}$ & $\begin{array}{c}0 \text { (Owned or } \\
\text { Leased) }\end{array}$ \\
\hline 2000 & $\begin{array}{l}0 \text { (Owned or } \\
\text { Leased) }\end{array}$ & $\begin{array}{l}0 \text { (Owned or } \\
\text { Leased) }\end{array}$ & & $\begin{array}{l}0 \text { (Owned or } \\
\text { Leased) }\end{array}$ & $\begin{array}{l}0 \text { (Owned or } \\
\text { Leased) }\end{array}$ \\
\hline 2002 & $\begin{array}{l}0 \text { (Owned or } \\
\text { Leased) }\end{array}$ & $\begin{array}{l}0 \text { (Owned or } \\
\text { Leased) }\end{array}$ & & $\begin{array}{l}0 \text { (Owned or } \\
\text { Leased) }\end{array}$ & $\begin{array}{l}0 \text { (Owned or } \\
\text { Leased) }\end{array}$ \\
\hline 2003 & $\begin{array}{l}0 \text { (Owned or } \\
\text { Leased) }\end{array}$ & $\begin{array}{l}0 \text { (Owned or } \\
\text { Leased) }\end{array}$ & & $\begin{array}{l}0 \text { (Owned or } \\
\text { Leased) }\end{array}$ & $\begin{array}{l}0 \text { (Owned or } \\
\text { Leased) }\end{array}$ \\
\hline 2004 & $\begin{array}{l}0 \text { (Owned or } \\
\text { Leased) }\end{array}$ & $\begin{array}{l}0 \text { (Owned or } \\
\text { Leased) }\end{array}$ & & $\begin{array}{l}0 \text { (Owned or } \\
\text { Leased) }\end{array}$ & $\begin{array}{l}0 \text { (Owned or } \\
\text { Leased) }\end{array}$ \\
\hline Program & Carpool & Carpool Parking & Vanpool & \multirow{2}{*}{$\begin{array}{c}\text { Vanpool Parking } \\
\text { Charge (Space/Month) }\end{array}$} & Reduced SOV \\
\hline Year & Parking Spaces & Charge & Parking & & Parking Space \\
\hline 1999 & 0 & & 0 & & 0 \\
\hline 2000 & & & & & \\
\hline 2002 & 0 & & 0 & & 0 \\
\hline 2003 & 0 & & 0 & & 0 \\
\hline 2004 & 0 & & 0 & & 0 \\
\hline
\end{tabular}

\section{Program Promotion}

\section{General (2004)}

Is the ETC's name, location and telephone number prominently displayed at this

Yes

Displayed where?

C.O. board, main entrance

Has the ETC completed a program developer/ETC training course?

On average, how many hours per week does the ETC spend on CTR activities?

Does the ETC have an active worksite committee to assist with the CTR

\section{Program promotion}

\begin{tabular}{|c|c|c|c|c|c|c|}
\hline $\begin{array}{l}\text { Program } \\
\text { Year }\end{array}$ & $\begin{array}{c}\text { Distribute } \\
\text { Summary of CTR }\end{array}$ & $\begin{array}{r}\mathrm{P} \\
\text { Inforr }\end{array}$ & \multicolumn{2}{|c|}{ Provide CTR Program } & $\begin{array}{c}\text { Post } \\
\text { Materials }\end{array}$ & $\begin{array}{c}\text { Give Managers } \\
\text { Presentation }\end{array}$ \\
\hline 1999 & Yes & & Yes & & Yes & Yes \\
\hline 2000 & Yes & & Yes & & Yes & Yes \\
\hline 2002 & Yes & & Yes & & Yes & Yes \\
\hline 2003 & Yes & & Yes & & Yes & Yes \\
\hline 2004 & Yes & & Yes & & Yes & Yes \\
\hline Program & Give & Conduct & Publish & Dist & bute & Distribute \\
\hline Year & Employees & CTR Events & CTR Articles & Informa & on with & Ridematch \\
\hline 1999 & Yes & Yes & Yes & $\mathrm{Ye}$ & & Yes \\
\hline 2000 & Yes & Yes & No & Ye & & Yes \\
\hline 2002 & Yes & Yes & No & $\mathrm{Ye}$ & & Yes \\
\hline 2003 & Yes & Yes & No & Ye & & Yes \\
\hline 2004 & Yes & Yes & No & $\mathrm{Ye}$ & & Yes \\
\hline
\end{tabular}

\section{Site Amenities}

$\begin{array}{cccccc}\begin{array}{c}\text { Program } \\ \text { Year }\end{array} & \begin{array}{c}\text { Covered } \\ \text { Bicycle Spaces }\end{array} & \begin{array}{c}\text { Uncovered } \\ \text { Bicycle Spaces }\end{array} & \begin{array}{c}\text { Clothes } \\ \text { Lockers }\end{array} & \text { Showers } & \begin{array}{c}\text { Non-SOV On-site } \\ \text { Loading/Unloading }\end{array} \\ 1999 & \text { No } & \text { Yes } & \text { Yes } & \text { Yes } & \text { No } \\ 2000 & \text { No } & \text { Yes } & \text { Yes } & \text { Yes } & \text { No } \\ 2002 & \text { No } & \text { Yes } & \text { Yes } & \text { Yes } & \text { No } \\ 2003 & \text { No } & \text { Yes } & \text { Yes } & \text { Yes } & \text { No } \\ 2004 & \text { Yes } & \text { Yes } & \text { Yes } & \text { Yes } & \text { No }\end{array}$




\section{Financial Subsidies, Incentives or Allowances}

$\begin{array}{ccccc}\begin{array}{c}\text { Program } \\ \text { Year }\end{array} & \begin{array}{c}\text { Transit Subsidy } \\ \text { (Employee/Month) }\end{array} & \begin{array}{c}\text { Vanpool Subsidy } \\ \text { (Employee/Month) }\end{array} & \begin{array}{c}\text { Carpool Subsidy } \\ \text { (Employee/Month) }\end{array} & \begin{array}{c}\text { Walking Subsidy } \\ \text { (Employee/Month) }\end{array} \\ 1999 & \$ 5 & 0 & 0 & 0 \\ 2000 & \$ 5 & 0 & 0 & 0 \\ 2002 & \$ 5 & 0 & 0 & 0 \\ 2003 & \$ 5 & 0 & 0 & 0 \\ 2004 & \$ 5 & 0 & 0 & 0 \\ \text { Program } & \text { Ferry Subsidy } & \text { Bicycling Subsidy } & \text { Other Stipend } & \\ \text { Year } & \text { (Employee/Month) } & \text { (Employee/Month } & \text { (Employee/Month) } \\ 1999 & 0 & 0 & 0 & \\ 2000 & 0 & 0 & 0 & \\ 2002 & 0 & 0 & 0 & \\ 2003 & 0 & 0 & 0 & \\ 2004 & 0 & 0 & 0 & \end{array}$

\section{Fleet Vehicles and Special Programs}

\section{Employer provided vehicles availability}

$\begin{array}{cccccc}\begin{array}{c}\text { Program } \\ \text { Year }\end{array} & \begin{array}{c}\text { FV Guaranteed } \\ \text { Ride Home }\end{array} & \text { FV Vanpool } & \begin{array}{c}\text { FV } \\ \text { Carpool }\end{array} & \begin{array}{c}\text { FV Work- } \\ \text { Related Trips }\end{array} & \begin{array}{c}\text { FV Non-Work } \\ \text { Related Errands }\end{array} \\ 1999 & \text { Yes } & \text { No } & \text { No } & \text { Yes } & \text { No } \\ 2000 & \text { Yes } & \text { No } & \text { No } & \text { Yes } & \text { No } \\ 2002 & \text { Yes } & \text { No } & \text { No } & \text { Yes } & \text { No } \\ 2003 & \text { Yes } & \text { No } & \text { No } & \text { Yes } & \text { No } \\ 2004 & \text { Yes } & \text { No } & \text { No } & \text { Yes } & \text { No }\end{array}$

Other services availability

$\begin{array}{cccc}\text { Program } & \text { Employer-Provided } & \text { Guaranteed Ride Home } & \text { Internal Match } \\ \text { Year } & \text { Shuttle } & \text { Program } & \\ 1999 & \text { No } & \text { Yes } & \\ 2000 & \text { No } & \text { Yes } & \\ 2002 & \text { No } & \text { Yes } & \text { No } \\ 2003 & \text { No } & \text { Yes } & \text { No } \\ 2004 & \text { No } & \text { Yes } & \end{array}$

\section{Mode Split and Vehicle Miles Traveled}

\begin{tabular}{|c|c|c|c|c|c|c|c|}
\hline $\begin{array}{l}\text { Program } \\
\text { Year }\end{array}$ & \multicolumn{2}{|c|}{$\begin{array}{l}\text { Num of Surveys } \\
\text { Distributed (Num of }\end{array}$} & \multicolumn{2}{|c|}{ Total Reported } & $\begin{array}{l}\text { Driving } \\
\text { Alone }\end{array}$ & Carpooling & Vanpooling \\
\hline 1995 & 16 & & 667 & & $76.9115 \%$ & $21.1394 \%$ & $0.0000 \%$ \\
\hline 1997 & 16 & & 538 & & $60.0372 \%$ & $34.9442 \%$ & $0.0000 \%$ \\
\hline 1999 & 19 & & 551 & & $61.8875 \%$ & $34.4828 \%$ & $0.0000 \%$ \\
\hline 2001 & 18 & & 602 & & $51.9934 \%$ & $37.2093 \%$ & $0.0000 \%$ \\
\hline 2003 & 16 & & 525 & & $66.2857 \%$ & $28.9524 \%$ & $0.0000 \%$ \\
\hline Program & Public & Bicycling & Walking & Othe & & hicle Miles & \\
\hline Year & Transit & & & & & Traveled & \\
\hline 1995 & $0.0000 \%$ & $0.0000 \%$ & $0.8996 \%$ & 1.049 & & 9.48 & \\
\hline 1997 & $3.9033 \%$ & $0.0000 \%$ & $0.0000 \%$ & 1.115 & & 8.72 & \\
\hline 1999 & $2.7223 \%$ & $0.9074 \%$ & $0.0000 \%$ & 0.000 & & 9.10 & \\
\hline 2001 & $8.3056 \%$ & $1.6611 \%$ & $0.8306 \%$ & 0.000 & & 6.57 & \\
\hline 2003 & $4.7619 \%$ & $0.0000 \%$ & $0.0000 \%$ & 0.000 & & 7.92 & \\
\hline
\end{tabular}




\section{Compressed Work Week, Flex Time and Teleworking Percentage of employees on Compressed Work}

\begin{tabular}{ccccc}
$\begin{array}{c}\text { Program } \\
\text { Year }\end{array}$ & $\begin{array}{c}\text { Num of Surveys } \\
\text { Distributed (Affected }\end{array}$ & $\begin{array}{c}\text { Total Surveys } \\
\text { Reported }\end{array}$ & $\begin{array}{c}\text { Percentage of Employees } \\
\text { On 5 Days/Week }\end{array}$ & $\begin{array}{c}\text { Percentage of Employees } \\
\text { On 3 Days/Week }\end{array}$ \\
1995 & 168 & 137 & $98.5401 \%$ & $0.0000 \%$ \\
1997 & 168 & 104 & $98.0769 \%$ & $0.0000 \%$ \\
1999 & 196 & 112 & $99.1071 \%$ & $0.0000 \%$ \\
2001 & 187 & 123 & $91.8699 \%$ & $0.0000 \%$ \\
2003 & 161 & 111 & $81.9820 \%$ & $0.0000 \%$ \\
Program & Percentage of Employees & Percentage of Employees & Percentage of Employees \\
Year & On 4 Days/Week & On 7 Days/Two Weeks & On 9 Days/Two Weeks \\
1995 & $1.4599 \%$ & \multicolumn{2}{c}{$0.0000 \%$} & $0.0000 \%$ \\
1997 & $1.9231 \%$ & $0.0000 \%$ & $0.0000 \%$ \\
1999 & $0.0000 \%$ & $0.0000 \%$ & $0.0000 \%$ \\
2001 & $7.3171 \%$ & $0.0000 \%$ & $0.0000 \%$ \\
2003 & $18.0180 \%$ & $0.0000 \%$ & & $0.0000 \%$
\end{tabular}

Percentage of employees on Telecommuting

\begin{tabular}{|c|c|c|c|c|c|}
\hline $\begin{array}{l}\text { Program } \\
\text { Year }\end{array}$ & \multicolumn{2}{|c|}{$\begin{array}{l}\text { Num of Surveys Distributed } \\
\text { (Num of Affected Employees) }\end{array}$} & $\begin{array}{l}\text { Total Surveys } \\
\text { Reported }\end{array}$ & $\begin{array}{l}\text { Total Percentage } \\
\text { of Telecommuters }\end{array}$ & $\begin{array}{l}1 \text { Days every } \\
\text { Two Weeks }\end{array}$ \\
\hline 1995 & \multicolumn{2}{|c|}{168} & & & \\
\hline 1997 & \multicolumn{2}{|c|}{168} & 108 & $0.0000 \%$ & $0.0000 \%$ \\
\hline 1999 & \multicolumn{2}{|c|}{196} & 112 & $5.3571 \%$ & $0.8929 \%$ \\
\hline 2001 & \multicolumn{2}{|c|}{187} & 118 & $1.6949 \%$ & $0.0000 \%$ \\
\hline 2003 & \multicolumn{2}{|c|}{161} & 110 & $1.8182 \%$ & $0.9091 \%$ \\
\hline Program & 2 Days every & 3 Days & 4 Days every & 5 Days every & More than 5 \\
\hline Year & Two Weeks & every Two & Two Weeks & Two Weeks & Days every Two \\
\hline \multicolumn{6}{|l|}{1995} \\
\hline 1997 & $0.0000 \%$ & $0.0000 \%$ & $0.0000 \%$ & $0.0000 \%$ & $0.0000 \%$ \\
\hline 1999 & $0.8929 \%$ & $0.0000 \%$ & $0.0000 \%$ & $1.7857 \%$ & $1.7857 \%$ \\
\hline 2001 & $0.0000 \%$ & $0.0000 \%$ & $0.0000 \%$ & $0.8475 \%$ & $0.8475 \%$ \\
\hline 2003 & $0.0000 \%$ & $0.0000 \%$ & $0.0000 \%$ & $0.0000 \%$ & $0.9091 \%$ \\
\hline
\end{tabular}




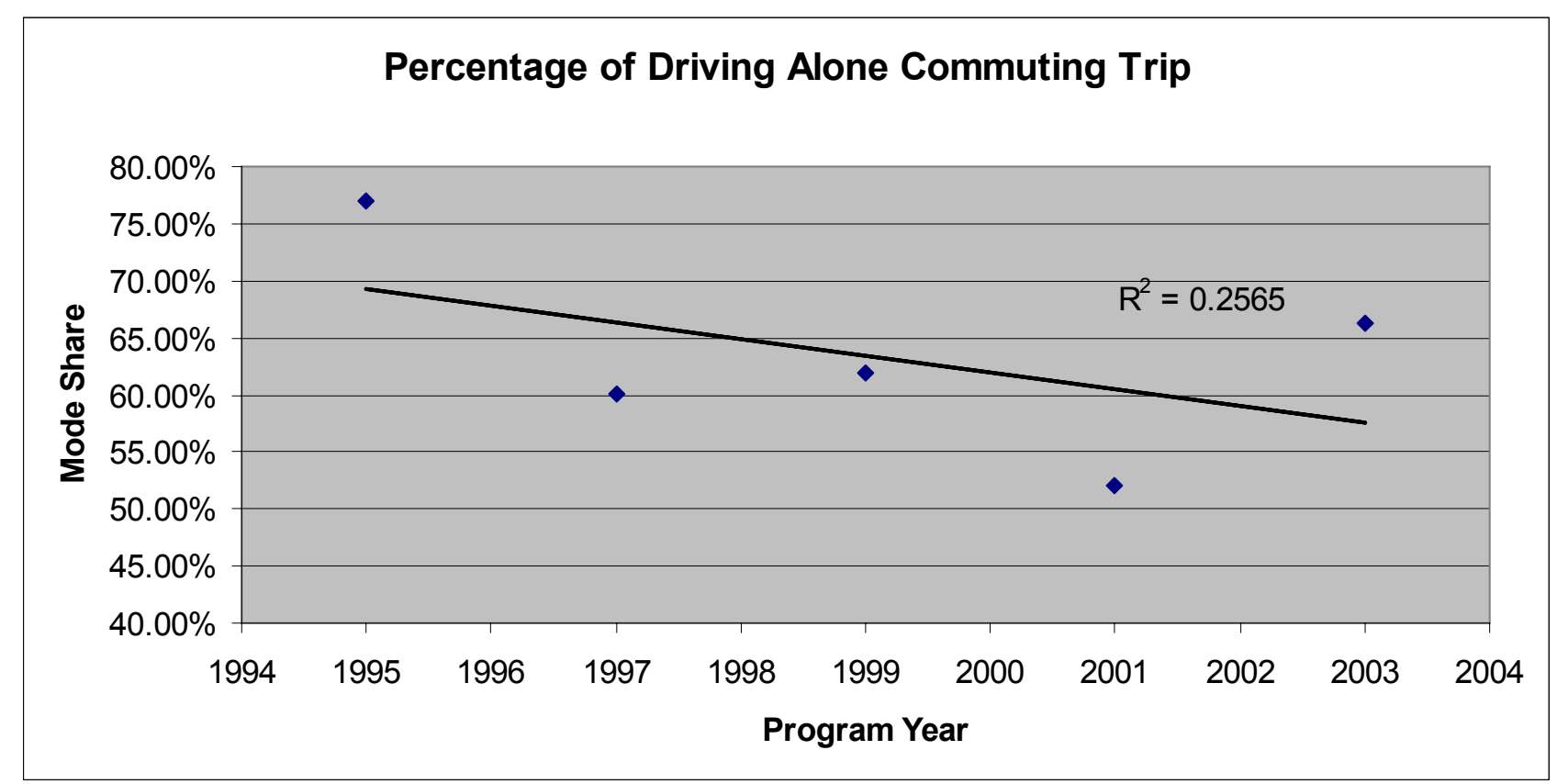

Figure 3: Percentage of Drive-Alone Commute Trips - Alsco

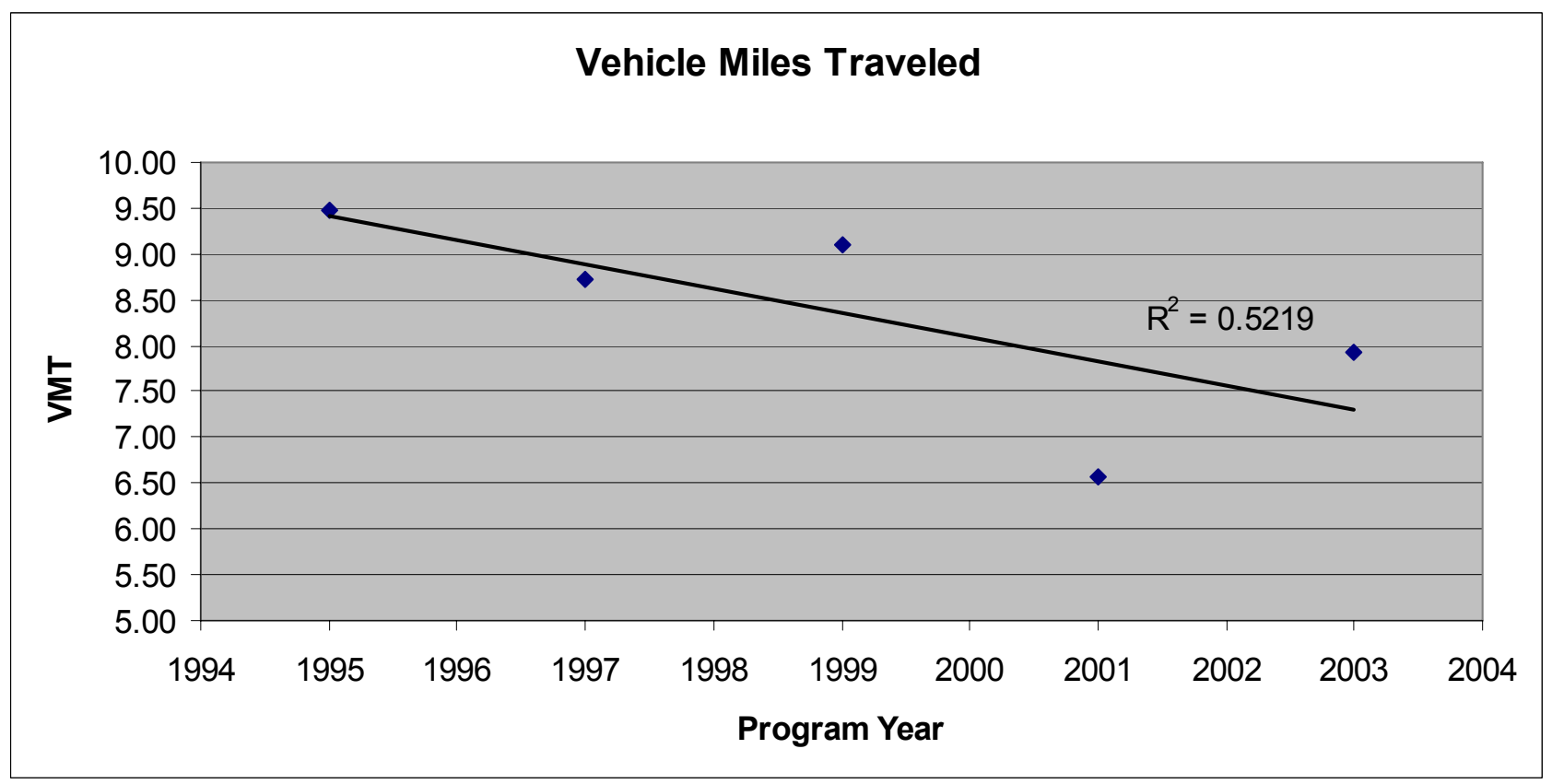

Figure 4: VMT - Alsco 


\section{Eastern State Hospital}

Medical Lake, WA

\section{Keys to Success}

Eastern State Hospital is a 24-hour psychiatric facility with approximately 650 employees located in a rural setting a mile outside of Medical Lake, Washington. Over the last decade, the hospital has helped almost 40 percent of their employees to use an alternative mode for their commute. One of the keys to their successful commute trip reduction (CTR) program is the significant financial support provided by the hospital. It is estimated that the hospital spends approximately $\$ 75,000$ a year providing their employees subsidies for transit, carpooling and vanpooling. Influenced by an organizational culture that values a healthy lifestyle, the CTR program is housed under its Wellness Program, thus cementing the relationship between commuting choices and health. Assistance from Spokane County's regional CTR Program, and particularly its Employee Transportation Coordinator (ETC) luncheons and their regional promotional campaign material, has also contributed to the success of the program.

\section{CTR Program Elements}

- Free transit pass, $\$ 30 /$ month value

- \$2/day carpool and vanpool subsidy

- Bicycle parking

- Showers and lockers

- $\mathrm{ETC}$

\section{Results and Costs}

From 1993 to 2003, survey results from Washington DOT indicate that Eastern State Hospital reduced their drive alone mode share from 77.1 percent to 63.6 percent. In that same time frame, the carpool mode share increased from 16.8 percent to 22.1 percent and vanpool mode share has increased from zero to 5.8 percent. The public transit mode share consistently averaged over 7 percent. As a result of these changes, the hospital's average one way vehicle miles traveled (VMT) per employee has decreased from 15.49 VMT to 13.25 VMT.

The estimated annual cost of Eastern State Hospital's CTR program is $\$ 75,000$, which includes the subsidies for transit, carpooling and vanpooling . 


\section{Eastern State Hospital}

Medical Lake, WA

\section{External Factors}

Like many worksites with successful work trip reduction programs, Eastern State Hospital's campus is well served by transit with a stop located onsite. This is not always the case with 24 hour operations with multiple shifts, but as the ETC expressed, Spokane Transit Authority (STA), the local transit agency, has worked with the hospital to accommodate their work schedules:

Our shifts are 6:45 to 3pm, 2:45 to 11pm, and 10:45 to $7 \mathrm{pm}$, and then the office staff work 8 to 4:15 Monday through Friday. I have worked here 32 years and STA, the local transit has always provided transit service at those times...they have met our needs.

The external support provided by Spokane County CTR Program helps the ETC perform her job more efficiently and effectively. She appreciates the time she saves by having access to the incentives and marketing materials from the regional campaigns.

We are part of the Spokane County CTR program and they have regular campaigns. We always participate in those and get the incentives and poster. So they have the campaign and we join in... that helps us to get a pre-packaged marketing campaign.

She also participates in the ETC luncheons hosted by the county's CTR program and has learned how to do her job more effectively from the guest speakers they have and from the ability to share knowledge and experience with other ETCs.

\section{Internal Factors}

The ETC firmly believes that the financial incentives provided to the hospital's employees are the main reasons for the program's success in reducing vehicle miles and the drive-alone mode share. Currently, the hospital provides free bus passes, and $\$ 2$ per day to employees that carpool or vanpool. Without limited or expensive parking or bad traffic congestion to push employees out of their cars, the primary reason for using an alternative mode expressed by employees is to save money. Most employees have at minimum a 20 minute drive and with the increased cost of gas, the CTR program has seen an increased demand for carpooling and vanpooling. Due to the need to safeguard patient information, telecommuting is not offered as part of their CTR program.

It is estimated that approximately $\$ 75,000$ per year is spent providing those benefits and other incentives, ranging from candy bars to hockey tickets, given during promotional campaigns. The financial commitment of the hospital is an illustration of the support the CTR program receives from upper management. Another way in which their support is demonstrated is in the program's chain of command; the ETC reports directly to the CEO of the hospital in matters concerning the CTR program. Approximately 10 percent of her total labor time is dedicated to administering the program. 


\section{Eastern State Hospital}

\section{Medical Lake, WA}

Although the hospital was required to provide the incentives because other branches of the Department of Health and Human Services were offering them in Olympia and Seattle under the state's trip reduction law, the CTR program fit well within the organizational or corporate culture of the campus. Eastern State Hospital's ETC believes that there is a connection between the support of the CTR program and the campus' organizational culture. Being a medical facility, high value is placed on promoting a healthy lifestyle not only for their patients, but also their employees. Therefore, it is not surprising that the CTR program is housed under the hospital's employee Wellness Program. By being a part of the Wellness Program, the CTR program can be incorporated into a wide variety of employee events and communicate a message relating commuting choices to healthy living.

Due to technology issues, Eastern State Hospital employees cannot easily use the regional rideshare system, so an internal system is maintained by the ETC. However, employees with access to computers use the online commute calendar program, mycommute.org, to record their work trips. The use of the online calendar saves labor time in collecting the data required by Washington DOT.

\section{Employee Transportation Coordinator}

The ETC has served as Eastern State's ETC for 10 years. The knowledge she has gained over that time from solving her co-workers commuting problems and running promotional campaigns has clearly contributed to the program's success. Her advice to new ETCs is to first find money by getting a budget commitment from upper management, and then establishing an employee committee to help with administering the program. The employee committee members help her with the internal ridematching and implementing the promotional campaign provided by the Spokane County CTR program. She also receives support from several employees, particularly vanpool drivers, who make an effort to solicit new employees to join the program. What she likes best about her job as ETC are the networking opportunities provided by the ETC luncheons. 


\title{
Organization Information (2004)
}

\section{Eastern State Hospital}

Medical Lake, WA

Website:

www.dshs.wa.gov

Primary Business:

Health Care

Non-profit organization? Yes

Total Employees: $\quad 650$

Affected Employees: $\quad 350$

Is the CTR program subject to collective bargaining? No

Does this worksite have multiple shifts? Yes

Shifts description:

6:45am to $3 \mathrm{pm} ; 8 \mathrm{am}$ to $4: 15 \mathrm{pm} ; 2: 45 \mathrm{pm}$ to $11 \mathrm{pm} ; 10: 45 \mathrm{pm}$ to $7 \mathrm{am}$

\section{CTR program contact:}

\author{
Aurora Crooks \\ TDM Manager, Spokane County CTR Office \\ 1026 W Broadway Ave., Spokane, WA 99260 \\ Phone: 509-477-7540 \\ Email: acrooks@spokanecounty.org
}

\section{Worksite Characteristics (2004)}

$\begin{array}{cccccc}\text { Bus stop(s) } & \text { Bike lane } & \text { Sidewalks } & \text { Restaurants } & \text { Shopping } & \text { Bank } \\ \text { Availability } & \text { Availability } & \text { Availability } & \text { Availability } & \text { Availability } & \text { Availability } \\ \text { Onsite } & \text { Within } 1 / 4 \text { mile } & \text { Onsite } & \text { Onsite } & \text { Not available } & \text { Not available }\end{array}$

\section{Program Narrative (2000)}

Eastern State Hospital participates in commute trip reduction, including biennial surveys (1999 was a survey year); participation in Spokane County and statewide CTR programs including rideshare, oil smart, bike to work; participation in Guaranteed Ride Home. The Hospital's Wellness committee is responsible for CTR activities. At each new employee orientation, a member of the committee provides information on CTR activities. The Committee provides financial incentives for CTR activities (using non-government funds) and other incentives such as hockey tickets, Indian tickets, etc. The hospital continues to provide preferred parking for carpool participants and subsidized bus passes.

\section{Worksite Parking and Parking Management Information}

Parking management and monitoring (2004)

Each preferred parking spot is assigned to an individual car/vanpool. That way, security can track appropriate use or non-use.

\begin{tabular}{|c|c|c|c|c|}
\hline \multicolumn{5}{|l|}{ Parking } \\
\hline $\begin{array}{l}\text { Program } \\
\text { Year }\end{array}$ & $\begin{array}{l}\text { Total Num of } \\
\text { Employees }\end{array}$ & $\begin{array}{c}\text { Onsite Parking } \\
\text { Spaces }\end{array}$ & $\begin{array}{c}\text { Offsite Parking } \\
\text { Spaces }\end{array}$ & $\begin{array}{l}\text { Leased Onsite } \\
\text { Parking Spaces }\end{array}$ \\
\hline 2000 & 63 & 600 & & 0 \\
\hline 2002 & 610 & 500 & & 0 \\
\hline 2003 & 610 & 500 & 0 & 0 \\
\hline 2004 & 650 & 550 & 0 & 0 \\
\hline Program & Leased Offsite & \multirow{2}{*}{\multicolumn{2}{|c|}{$\begin{array}{l}\text { Leased Onsite Parking } \\
\text { Price (Space/Month) }\end{array}$}} & Leased Offsite Parking \\
\hline Year & Parking Spaces & & & Price (Space/Month) \\
\hline 2000 & 0 & & & \\
\hline 2002 & 0 & & & \\
\hline 2003 & 0 & & & \\
\hline 2004 & 0 & & & \\
\hline
\end{tabular}




\section{Parking management}

\begin{tabular}{|c|c|c|c|c|c|c|}
\hline $\begin{array}{l}\text { Program } \\
\text { Year }\end{array}$ & $\begin{array}{l}\text { Owned Onsite } \\
\text { Parking Charge }\end{array}$ & Owned Offsite & \multicolumn{2}{|c|}{$\begin{array}{l}\text { Leased Onsite } \\
\text { Parking Charoe }\end{array}$} & \multicolumn{2}{|c|}{ Leased Offsite } \\
\hline 2000 & $\begin{array}{c}0 \text { (Owned or } \\
\text { Leased) }\end{array}$ & $\begin{array}{c}0 \text { (Owned o } \\
\text { Leased) }\end{array}$ & & $\begin{array}{l}\text { wned or } \\
\text { ased) }\end{array}$ & & $\begin{array}{l}\text { wned or } \\
\text { ased) }\end{array}$ \\
\hline 2002 & 0 & 0 & & & & \\
\hline 2003 & 0 & 0 & & 0 & & 0 \\
\hline 2004 & 0 & 0 & & 0 & & 0 \\
\hline Program & Carpool & Carpool Parking & Vanpool & Vanpool & & Reduced SOV \\
\hline $\begin{array}{l}\text { Year } \\
2000\end{array}$ & $\begin{array}{l}\text { Parking Spaces } \\
55\end{array}$ & Charge & Parking & Charge (Spa & onth) & Parking Space \\
\hline 2002 & $\begin{array}{c}44 \text { (Carpool \& } \\
\text { Vanpool) }\end{array}$ & 0 & $\begin{array}{c}44 \text { (Carpool \& } \\
\text { Vanpool) }\end{array}$ & 0 & & 50 \\
\hline 2003 & $\begin{array}{c}44 \text { (Carpool \& } \\
\text { Vanpool) }\end{array}$ & 0 & $\begin{array}{c}44 \text { (Carpool \& } \\
\text { Vanpool) }\end{array}$ & 0 & & 50 \\
\hline 2004 & $\begin{array}{c}44 \text { (Carpool \& } \\
\text { Vanpool) }\end{array}$ & 0 & $\begin{array}{c}44 \text { (Carpool \& } \\
\text { Vanpool) }\end{array}$ & 0 & & 0 \\
\hline
\end{tabular}

\section{Program Promotion}

\section{General (2004)}

Is the ETC's name, location and telephone number prominently displayed at this

Yes

Displayed where?

Commute Options bulletin board, Administration Bldg

Has the ETC completed a program developer/ETC training course?

On average, how many hours per week does the ETC spend on CTR activities?

Does the ETC have an active worksite committee to assist with the CTR

\section{Yes \\ 1}

Yes

\section{Program promotion}

\begin{tabular}{|c|c|c|c|c|c|c|}
\hline $\begin{array}{l}\text { Program } \\
\text { Year }\end{array}$ & $\begin{array}{c}\text { Distribute } \\
\text { Summary of CTR }\end{array}$ & \multicolumn{3}{|c|}{$\begin{array}{l}\text { Provide CTR Program } \\
\text { Information to New Employees }\end{array}$} & $\begin{array}{c}\text { Post } \\
\text { Materials }\end{array}$ & $\begin{array}{l}\text { Give Managers } \\
\text { Presentation }\end{array}$ \\
\hline 2000 & Yes & & Yes & & Yes & Yes \\
\hline 2002 & Yes & & Yes & & Yes & Yes \\
\hline 2003 & Yes & & Yes & & Yes & Yes \\
\hline 2004 & Yes & & Yes & & Yes & Yes \\
\hline Program & Give & Conduct & Publish & Distr & bute & Distribute \\
\hline Year & Employees & TR Events & CTR Articles & Informat & Ion with & Ridematch \\
\hline 2000 & Yes & No & Yes & Ye & & Yes \\
\hline 2002 & Yes & Yes & No & Ye & & Yes \\
\hline 2003 & Yes & Yes & No & Ye & & Yes \\
\hline 2004 & Yes & Yes & No & Ye & & Yes \\
\hline
\end{tabular}

\section{Site Amenities}

$\begin{array}{cccccc}\begin{array}{c}\text { Program } \\ \text { Year }\end{array} & \begin{array}{c}\text { Covered } \\ \text { Bicycle Spaces }\end{array} & \begin{array}{c}\text { Uncovered } \\ \text { Bicycle Spaces }\end{array} & \begin{array}{c}\text { Clothes } \\ \text { Lockers }\end{array} & \text { Showers } & \begin{array}{c}\text { Non-SOV On-site } \\ \text { Loading/Unloading }\end{array} \\ 2000 & \text { Yes } & \text { Yes } & \text { Yes } & \text { Yes } & \text { No } \\ 2002 & \text { No } & \text { Yes } & \text { Yes } & \text { Yes } & \text { No } \\ 2003 & \text { No } & \text { Yes } & \text { Yes } & \text { Yes } & \text { No } \\ 2004 & \text { No } & \text { Yes } & \text { Yes } & \text { Yes } & \text { No }\end{array}$




\section{Financial Subsidies, Incentives or Allowances}

\begin{tabular}{|c|c|c|c|c|}
\hline $\begin{array}{l}\text { Program } \\
\text { Year }\end{array}$ & $\begin{array}{c}\text { Transit Subsidy } \\
\text { (Employee/Month) }\end{array}$ & $\begin{array}{l}\text { Vanpool Subsidy } \\
\text { (Employee/Month) }\end{array}$ & $\begin{array}{l}\text { Carpool Subsidy } \\
\text { (Employee/Month) }\end{array}$ & $\begin{array}{l}\text { Walking Subsidy } \\
\text { (Employee/Month) }\end{array}$ \\
\hline 2000 & $\$ 2.5$ & 0 & & \\
\hline 2002 & 0 & \$2/Day & $\$ 2$ & $\$ 2$ \\
\hline 2003 & 0 & Up to $\$ 40$ & Up to $\$ 40$ & Up to $\$ 40$ \\
\hline 2004 & 0 & \$2/Day & $\$ 2$ & $\$ 2$ \\
\hline $\begin{array}{l}\text { Program } \\
\text { Year }\end{array}$ & $\begin{array}{c}\text { Ferry Subsidy } \\
\text { (Employee/Month) }\end{array}$ & $\begin{array}{l}\text { Bicycling Subsidy } \\
\text { (Employee/Month }\end{array}$ & $\begin{array}{c}\text { Other Stipend } \\
\text { (Employee/Month) }\end{array}$ & \\
\hline 2000 & 0 & & 0 & \\
\hline 2002 & 0 & $\$ 2$ & 0 & \\
\hline 2003 & 0 & Up to $\$ 40$ & 0 & \\
\hline 2004 & 0 & $\$ 2$ & 0 & \\
\hline
\end{tabular}

\section{Fleet Vehicles and Special Programs}

\section{Employer provided vehicles availability}

$\begin{array}{cccccc}\begin{array}{c}\text { Program } \\ \text { Year }\end{array} & \begin{array}{c}\text { FV Guaranteed } \\ \text { Ride Home }\end{array} & \text { FV Vanpool } & \begin{array}{c}\text { FV } \\ \text { Carpool }\end{array} & \begin{array}{c}\text { FV Work- } \\ \text { Related Trips }\end{array} & \begin{array}{c}\text { FV Non-Work } \\ \text { Related Errands }\end{array} \\ 2000 & \text { No } & \text { No } & \text { No } & \text { Yes } & \text { No } \\ 2002 & \text { Yes } & \text { No } & \text { No } & \text { Yes } & \text { No } \\ 2003 & \text { Yes } & \text { No } & \text { No } & \text { Yes } & \text { No } \\ 2004 & \text { Yes } & \text { No } & \text { No } & \text { Yes } & \text { No }\end{array}$

Other services availability

$\begin{array}{cccc}\text { Program } & \text { Employer-Provided } & \text { Guaranteed Ride Home } & \text { Internal Match } \\ \text { Year } & \text { Shuttle } & \text { Program } & \text { Program } \\ 2000 & \text { Yes } & \text { Yes } & \\ 2002 & \text { Yes } & \text { Yes } & \text { No } \\ 2003 & \text { Yes } & \text { Yes } & \text { No } \\ 2004 & \text { Yes } & \text { Yes } & \text { No }\end{array}$

\section{Mode Split and Vehicle Miles Traveled}

\begin{tabular}{|c|c|c|c|c|c|c|c|}
\hline $\begin{array}{l}\text { Program } \\
\text { Year }\end{array}$ & \multicolumn{2}{|c|}{$\begin{array}{l}\text { Num of Surveys } \\
\text { Distributed (Num of }\end{array}$} & \multicolumn{2}{|c|}{$\begin{array}{l}\text { Total Reported } \\
\text { Commuting Days }\end{array}$} & $\begin{array}{c}\text { Driving } \\
\text { Alone }\end{array}$ & Carpooling & Vanpooling \\
\hline 1993 & 38 & & 1190 & & $77.0588 \%$ & $16.8067 \%$ & $0.0000 \%$ \\
\hline 1995 & 53 & & 1119 & & $71.8499 \%$ & $19.3923 \%$ & $0.0000 \%$ \\
\hline 1997 & 62 & & 1074 & & $72.2533 \%$ & $20.4842 \%$ & $0.0000 \%$ \\
\hline 1999 & 55 & & 1085 & & $70.5991 \%$ & $20.0000 \%$ & $0.0000 \%$ \\
\hline 2001 & 38 & & 1147 & & $67.3932 \%$ & $20.1395 \%$ & $4.2720 \%$ \\
\hline 2003 & 41 & & 1073 & & $63.6533 \%$ & $22.0876 \%$ & $5.8714 \%$ \\
\hline Program & Public & Bicycling & Walking & Other & & hicle Miles & \\
\hline Year & Transit & & & & & Traveled & \\
\hline 1993 & $5.0420 \%$ & $0.3361 \%$ & $0.4202 \%$ & 0.3361 & & 15.49 & \\
\hline 1995 & $7.5961 \%$ & $0.5362 \%$ & $0.5362 \%$ & 0.0894 & & 14.91 & \\
\hline 1997 & $5.4935 \%$ & $0.6518 \%$ & $0.3724 \%$ & 0.7449 & & 13.66 & \\
\hline 1999 & $7.6498 \%$ & $0.7373 \%$ & $0.4608 \%$ & 0.5530 & & 13.35 & \\
\hline 2001 & $7.5850 \%$ & $0.1744 \%$ & $0.2616 \%$ & 0.1744 & & 13.07 & \\
\hline 2003 & $7.4557 \%$ & $0.0932 \%$ & $0.1864 \%$ & 0.6524 & & 13.25 & \\
\hline
\end{tabular}




\title{
Compressed Work Week, Flex Time and Teleworking
}

\section{Policy (2000)}

Flex Time

Because the hospital is a 24/7, flex time for professional and others is not

Teleworking

\author{
encouraged. Housekeeping and some staff participate. The CEO has
}

\begin{tabular}{|c|c|c|c|c|c|}
\hline Program & Num of Surveys & Total Surveys & \multirow{2}{*}{\multicolumn{2}{|c|}{$\begin{array}{c}\text { Percentage of Employees } \\
\text { On } 5 \text { Days/Week }\end{array}$}} & Percentage of Employees \\
\hline Year & Distributed (Affected & Reported & & & On 3 Days/Week \\
\hline 1993 & 385 & 264 & \multicolumn{2}{|c|}{$96.5909 \%$} & $0.3788 \%$ \\
\hline 1995 & 537 & 256 & \multicolumn{2}{|c|}{$97.2656 \%$} & $0.0000 \%$ \\
\hline 1997 & 620 & 248 & \multicolumn{2}{|c|}{$89.5161 \%$} & $0.0000 \%$ \\
\hline 1999 & 558 & 251 & \multicolumn{2}{|c|}{$87.2510 \%$} & $0.0000 \%$ \\
\hline 2001 & 388 & 270 & \multicolumn{2}{|c|}{$89.6296 \%$} & $0.7407 \%$ \\
\hline 2003 & 415 & 248 & \multicolumn{2}{|c|}{$93.9516 \%$} & $0.4032 \%$ \\
\hline Program & Percentage of Employees & \multirow{2}{*}{\multicolumn{2}{|c|}{$\begin{array}{c}\text { Percentage of Employees } \\
\text { On } 7 \text { Days/Two Weeks }\end{array}$}} & \multicolumn{2}{|c|}{ Percentage of Employees } \\
\hline Year & On 4 Days/Week & & & On $9 \mathrm{Da}$ & ss/Two Weeks \\
\hline 1993 & $2.6515 \%$ & \multicolumn{2}{|c|}{$0.0000 \%$} & \multicolumn{2}{|c|}{$0.0000 \%$} \\
\hline 1995 & $2.3438 \%$ & \multicolumn{2}{|c|}{$0.0000 \%$} & \multicolumn{2}{|c|}{$0.0000 \%$} \\
\hline 1997 & $10.0806 \%$ & \multicolumn{2}{|c|}{$0.4032 \%$} & \multicolumn{2}{|c|}{$0.0000 \%$} \\
\hline 1999 & $10.3586 \%$ & \multicolumn{2}{|c|}{$0.0000 \%$} & \multicolumn{2}{|c|}{$0.3984 \%$} \\
\hline 2001 & $5.9259 \%$ & \multicolumn{2}{|c|}{$0.3704 \%$} & \multicolumn{2}{|c|}{$1.8519 \%$} \\
\hline 2003 & $2.4194 \%$ & \multicolumn{2}{|c|}{$0.0000 \%$} & & $2097 \%$ \\
\hline
\end{tabular}

\section{Percentage of employees on Telecommuting}

\begin{tabular}{|c|c|c|c|c|c|}
\hline $\begin{array}{l}\text { Program } \\
\text { Year }\end{array}$ & \multicolumn{2}{|c|}{$\begin{array}{l}\text { Num of Surveys Distributed } \\
\text { (Num of Affected Employees) }\end{array}$} & $\begin{array}{l}\text { Total Surveys } \\
\text { Reported }\end{array}$ & $\begin{array}{l}\text { Total Percentage } \\
\text { of Telecommuters }\end{array}$ & $\begin{array}{l}1 \text { Days every } \\
\text { Two Weeks }\end{array}$ \\
\hline 1993 & \multicolumn{2}{|c|}{385} & 272 & $1.4706 \%$ & $0.3676 \%$ \\
\hline 1995 & \multicolumn{2}{|c|}{537} & 259 & $0.7722 \%$ & $0.0000 \%$ \\
\hline 1997 & \multicolumn{2}{|c|}{620} & 250 & $0.8000 \%$ & $0.0000 \%$ \\
\hline 1999 & \multicolumn{2}{|c|}{558} & 245 & $1.2245 \%$ & $0.0000 \%$ \\
\hline 2001 & \multicolumn{2}{|c|}{388} & 260 & $1.1538 \%$ & $0.0000 \%$ \\
\hline 2003 & \multicolumn{2}{|c|}{415} & 243 & $0.4115 \%$ & $0.0000 \%$ \\
\hline Program & 2 Days every & 3 Days & 4 Days every & 5 Days every & More than 5 \\
\hline Year & Two Weeks & every Two & Two Weeks & Two Weeks & Days every Two \\
\hline 1993 & $0.0000 \%$ & $0.0000 \%$ & $0.0000 \%$ & $0.0000 \%$ & $1.1029 \%$ \\
\hline 1995 & $0.0000 \%$ & $0.3861 \%$ & $0.0000 \%$ & $0.0000 \%$ & $0.3861 \%$ \\
\hline 1997 & $0.0000 \%$ & $0.0000 \%$ & $0.0000 \%$ & $0.4000 \%$ & $0.4000 \%$ \\
\hline 1999 & $0.0000 \%$ & $0.0000 \%$ & $0.0000 \%$ & $0.0000 \%$ & $1.2245 \%$ \\
\hline 2001 & $0.7692 \%$ & $0.0000 \%$ & $0.3846 \%$ & $0.0000 \%$ & $0.0000 \%$ \\
\hline 2003 & $0.0000 \%$ & $0.0000 \%$ & $0.0000 \%$ & $0.0000 \%$ & $0.4115 \%$ \\
\hline
\end{tabular}




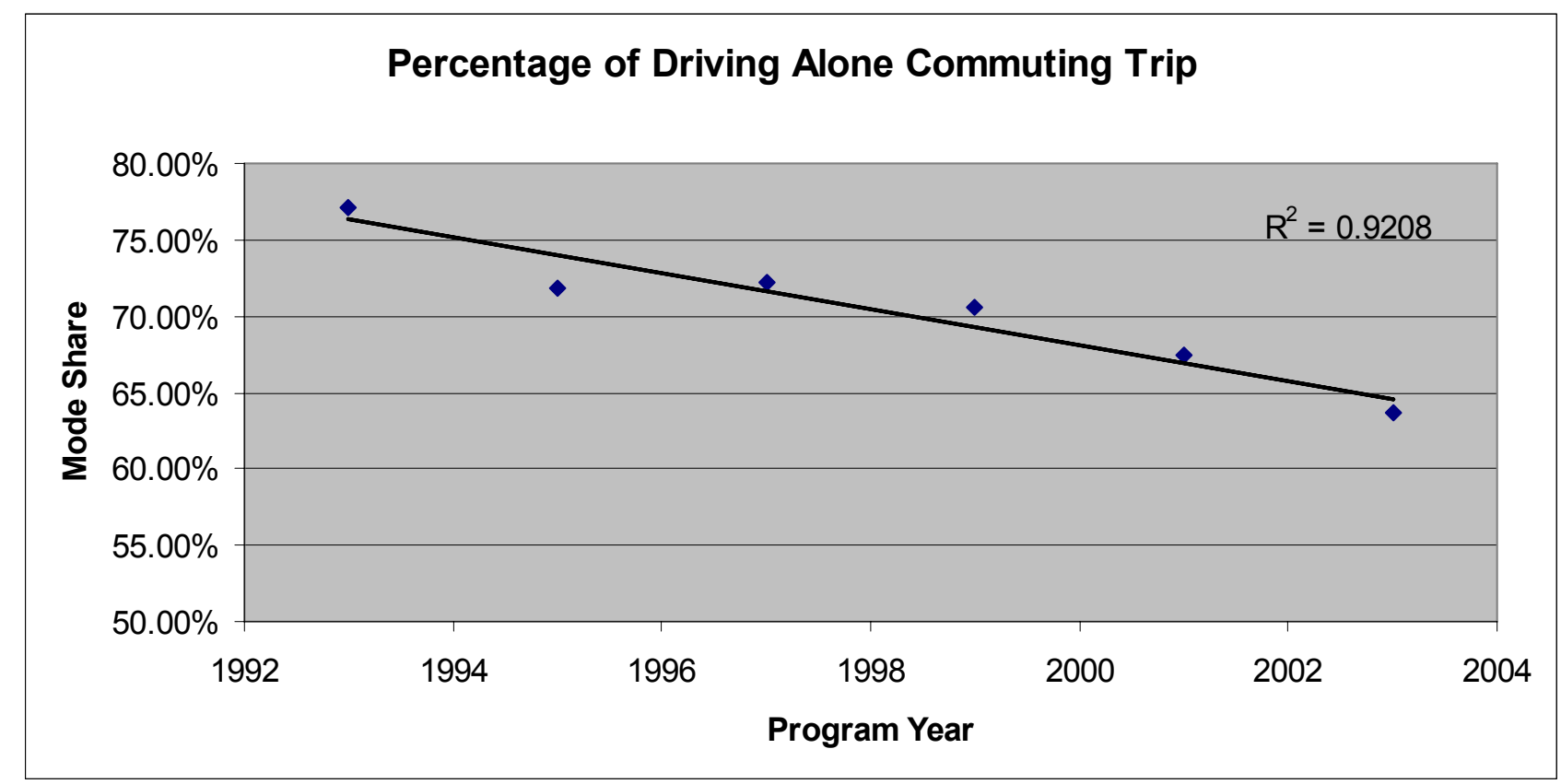

Figure 5: Percentage of Drive-Alone Commute Trips - Eastern State Hospital

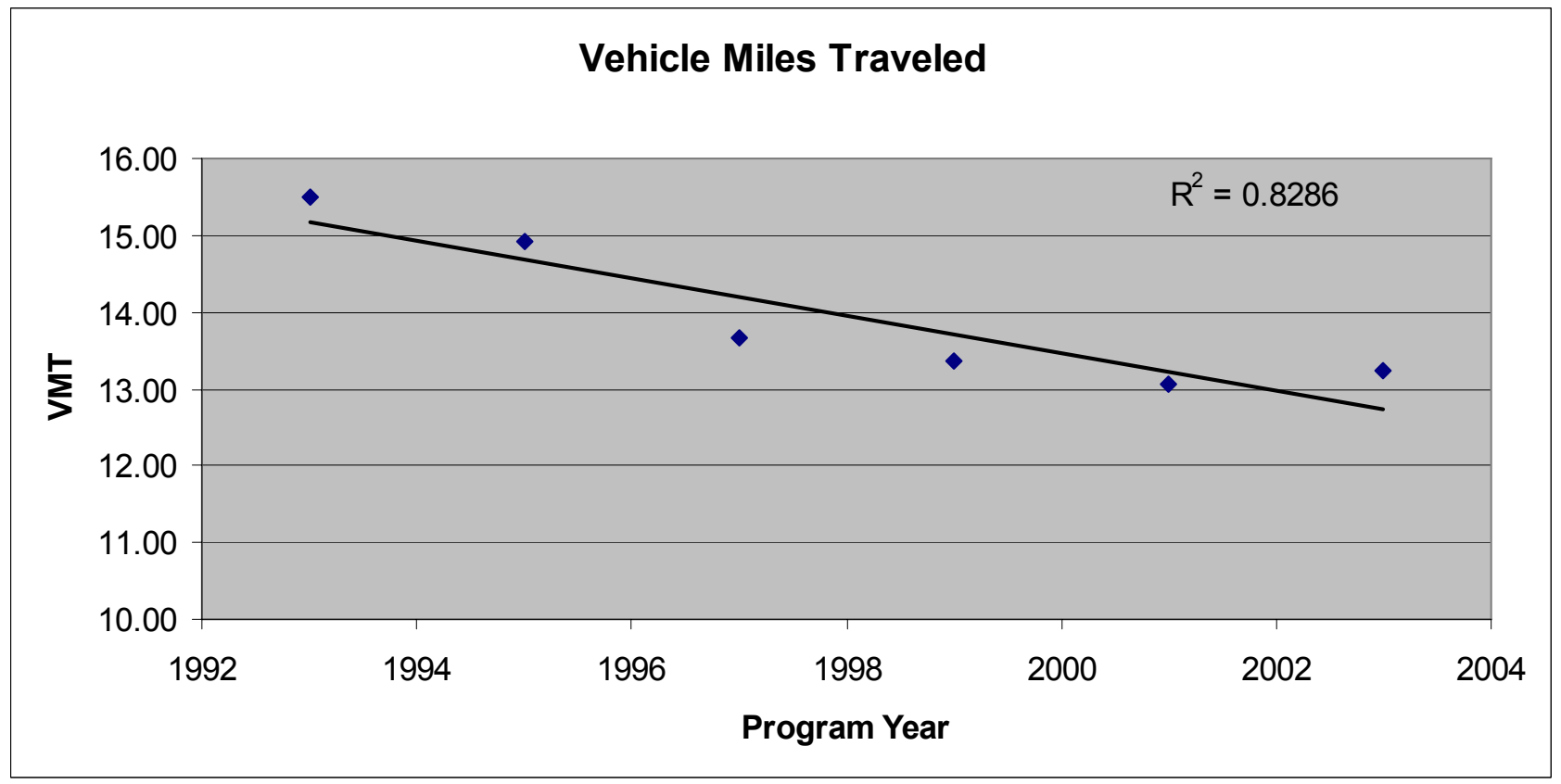

Figure 6: VMT - Eastern State Hospital 


\section{Evergreen State College}

Olympia, WA

\section{Keys to Success}

Established in 1967, Evergreen State College is located a few miles outside of Olympia, Washington in a rural setting. For the 425 faculty and staff employees and students, the Parking Services' Commute Trip Reduction (CTR) program offers a wide variety of benefits and incentives to promote the use of alternative modes. The college provides universal bus passes to students, faculty and staff, and subsidies for faculty and staff for carpooling, bicycling, and walking to campus. The Parking Supervisor and designated ETC, believes that in addition to the benefits and incentives, the campus' strong sense of environmentalism motivates employees and students to ride the bus, bicycle or carpool to campus. The ETC credits the outside assistance of the Thurston Regional Planning Council's CTR program staff with provide the college valuable assistance in maintaining and expanding their program. The CTR program receives approximately $\$ 5,000$ per year to administer the program from the Parking Services Department's budget. Another reason for the success of the college's CTR program is the amount of time invested administering it. The ETC estimates that she spends a quarter of her time on the program and also receives the assistance of a student transportation coordinator who works 10-19 hours per week promoting commute alternatives on campus.

\section{Results and Cost}

Between 1993 and 2000, Evergreen State College's drive-alone mode share for employees has decreased from 80.9 percent to 72.7 percent. In that same timeframe, the public transit, carpool, and bicycle mode shares have all increased by approximately 3 percentage points. As a result of these changes, the college's average one way vehicle miles traveled (VMT) per employee has decreased from 11.48 VMT to 9.84 VMT.

The CTR program receives $\$ 5,000$ per year to market and promote the program and employs a student transportation coordinator.

\section{CTR Program Elements}

- Free transit passes for students, faculty and staff

- Carpool, walking and bicycling subsidies of $\$ 11.25$ per month for employees

- Vanpool subsidy of $\$ 21.25$ per month for employees

- Bicycle parking

- Showers and lockers

- CRT committee 


\section{Evergreen State College}

Olympia, WA

- Student transportation coordinator

- Dedicated budget of $\$ 5,000$ per year

\section{External Factors}

The campus is in a rural setting, outside the city limits of Olympia. Most students and employees remain on campus during the day as the campus is approximately three to five miles from shopping opportunities, but there are at least four eateries and a bookstore located on the campus. Most freshman students live on campus, while older students tend to commute more to the campus.

The campus is served by two different routes with headways of about 30 minutes. Students, faculty and staff receive a free bus pass, although the cost of the bus pass for students is taken out of the general fees they pay at enrollment. Parking fees are very inexpensive and there are adequate spaces. However, the parking is primarily located on the periphery of campus. The remoteness of the parking makes transit a more attractive option for some since it penetrates deeper into campus and significantly decreases the amount of walking required. According to the ETC, "people in Olympia and at Evergreen State really take seriously the alternative commuting concept." It may take employees more time to ride the bus, but their environmental values override that disadvantage.

Traffic congestion is generally not an external factor that pushes employees or students into alternative modes. Only at the beginning of each quarter does traffic congestion become an issue as students and faculty are adjusting to new schedules.

Evergreen State's ETC receives significant outside support from Washington DOT staff and the regional commuter assistance program run by the Thurston Regional Planning Council (RPC), and in particular, through their ETC network. Evergreen State coordinates with Intercity Transit to implement the state trip reduction program promotions, including Rideshare Week, Oil Smart Week and Feet Week. In 2003, when the CTR program was moved into the Parking Services Department, the DOT and RPC staff met with the ETC and other college employees to help them redesign their program. The redesign included extending the benefits of the program, particularly the universal transit pass element, to the students of the college. Currently, the ETC is participating on Interagency CTR Taskforce, to provide recommendations on how the State can provide better assistance to state agencies required by law to have CTR programs. The taskforce's mission is to evaluate the rules and how they apply to state agencies and to increase the level of consistency on how they must comply with the CTR laws.

The increased cost of gas has motivated more students and employees to use alternatives, and that the college administration, in addition to Parking Services' CTR program, has been encouraging students and employees to consider using an alternative in response to the increased cost of gas. 


\section{Evergreen State College}

Olympia, WA

\section{Internal Factors}

Evergreen State College provides a wide variety benefits and incentives to employees and students to promote alternative mode use. Students and staff can use transit for free through a universal pass program. Those employees that carpool, vanpool, walk or bicycle to campus also receive a subsidy from the college. The vanpool subsidy is currently $\$ 21.25$ per month and $\$ 11.25$ per month for carpooling, walking, or bicycling to campus. The CTR program maintains a database for college employees to help form ridesharing arrangements. Bicycling is very popular on campus among students, and Parking Services has provided excellent bicycle parking facilities for them. Although there are no rules concerning students having cars on campus, Parking Services does recommend to parents during freshman orientation not to have their sons and daughters bring cars if they are living on campus.

The ETC believes that the CTR program is philosophically aligned with the mission of the college, so it was a natural fit. For faculty and staff, environmentalism combined with financial savings are viewed as the primary reasons for using an alternative mode. For those faculty and staff that do not use an alternative, the reason most frequently heard by Parking Services is that it is more convenient for them to drive to campus.

Administrative support of the program is not considered by the ETC to be a critical component of the CTR program's success. Although she receives a budget, managing the CTR is not a part of her formal job description and the administration has not gone out of their way to help promote the program visually. On the other hand, when she has gone to the Administration with ideas for new elements, they have always given her the "green light to go for it."

The CTR program at Evergreen State communicates to students, faculty and staff through a newsletter that is distributed twice per year. The ETC also credits the campus radio station for promoting the program and providing innovative ways to reach the students.

\section{Employee Transportation Coordinator}

The ETC is the Parking Supervisor for Evergreen State College's Parking Services department. She has served as the ETC for 3 years and has work in the Parking Services department for 10 years. Prior to the program coming under the umbrella of Parking Services, it was run out of the Motor Pool Department which manages college-owned vehicles.

In 2005, a CTR program committee was re-established on campus that had been dissolved in years past. A general call was issued for volunteers for the committee and there was a significant response. The committee helps implement the regional promotions and make decisions on future elements of the program. The committee is interested in establishing an electric campus shuttle system on campus to serve the remote parking as well as the core of campus and having the Human Resources Department overcome their apprehension regarding telecommuting. 


\section{Evergreen State College}

\section{Olympia, WA}

Managing the CTR program is not part of her job description, but she estimates that she spends 25 percent of her time doing it. She also receives support from the student transportation coordinator and a volunteer committee to manage the program and implement the regional campaigns supplied through the Thurston RPC. 


\section{Organization Information (2004)}

\section{The Evergreen State College \\ Olympia, WA}

Website:

www.evergreen.edu

Primary Business:

Education

Non-profit organization?

Yes

Total Employees:

425

Affected Employees:

391

Is the CTR program subject to collective bargaining? No

Does this worksite have multiple shifts? Yes

Shifts description:

Custodians in Building Services have two shifts and Police Services have three

\section{CTR program contact:}

Holly Gilbert

Senior Planner, Thurston Regional Planning Council

2404 Heritage Ct. SW \#B, Olympia, WA 98502

Phone: (360) 786-5480

Email: gilberh@trpc.org

\section{Worksite Characteristics (2004)}

$\begin{array}{cccccc}\text { Bus stop(s) } & \text { Bike lane } & \text { Sidewalks } & \text { Restaurants } & \text { Shopping } & \text { Bank } \\ \text { Availability } & \text { Availability } & \text { Availability } & \text { Availability } & \text { Availability } & \text { Availability } \\ \text { Onsite } & \text { Onsite } & \text { Onsite } & \text { Onsite } & \text { Onsite } & \text { Onsite }\end{array}$

\section{Program Narrative (2000)}

Promotions: We participate in the major promotions sponsored by Intercity Transit and the State including Rideshare Week, Oil Smart Month, the Bicycle contest and Vacation from Traffic. In addition we have and plan to have several promotions including "Feet Week" (for bicyclists and walkers), Graduation Day (leave car at home to clear lots for guests), the 'Buddy' contest (promote Guaranteed Ride Home). Newsletter: We publish a newsletter twice a year with information on alternative modes and profiles of propel on campus who use alternative. Database: We have a database with employee's home addresses and other commute related information that we plan on using to help people find rideshare partners. Web site: We have a commute trip reduction web site on Evergreen's home page. Within the coming year, we hope to expand the web site to include the ability to list rides wanted and offered for both students and faculty/staff. At this time, there is a link to Transportation Connections which offers this service. Transit Fair is planned in December with representatives from the Bike Shop, Intercity Transit, the Wellness Center as well as the Commute Trip Reduction Committee. Employees will be encouraged to drop by and have a cup of hot cider, cookies and popcorn, listen to music, have a chair massage, relax and explore their commute alternatives. Contact: Primary contact has been e-mail. We also utilize flyers to promote major events and send out notices of events via campus mail to those groups that do not have email access.

\section{Worksite Parking and Parking Management Information}

\section{Parking management and monitoring (2004)}

Parking rules are mandated by RCW's. Parking rate changes are subject to public hearings. Parking Services monitors lots, collects parking fees 


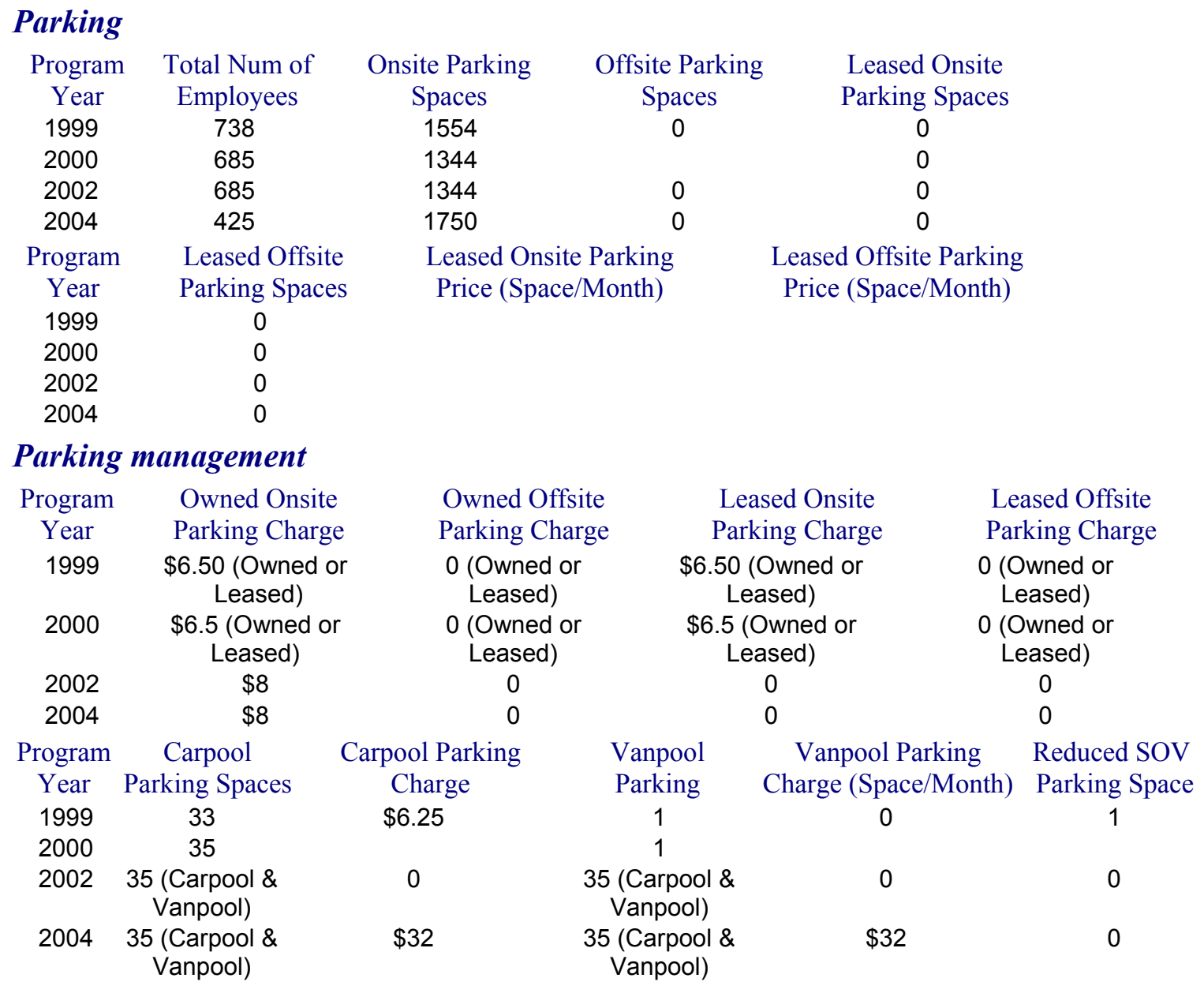

\section{Program Promotion}

General (2004)

Is the ETC's name, location and telephone number prominently displayed at this

No

Displayed where? New signs have been ordered.

Has the ETC completed a program developer/ETC training course?

On average, how many hours per week does the ETC spend on CTR activities? 10

Does the ETC have an active worksite committee to assist with the CTR Yes

\section{Program promotion}

\begin{tabular}{|c|c|c|c|c|c|c|}
\hline $\begin{array}{l}\text { Program } \\
\text { Year }\end{array}$ & $\begin{array}{c}\text { Distribute } \\
\text { Summary of CTR }\end{array}$ & \multicolumn{3}{|c|}{ Provide CTR Program } & $\begin{array}{c}\text { Post } \\
\text { Materials }\end{array}$ & $\begin{array}{l}\text { Give Managers } \\
\text { Presentation }\end{array}$ \\
\hline 1999 & Yes & & Yes & & Yes & Yes \\
\hline 2000 & Yes & & Yes & & Yes & No \\
\hline 2002 & Yes & & Yes & & Yes & No \\
\hline 2004 & Yes & & Yes & & Yes & No \\
\hline Program & Give & Conduct & Publish & Distr & bute & Distribute \\
\hline Year & Employees & CTR Events & CTR Articles & Informat & ion with & Ridematch \\
\hline 1999 & Yes & Yes & Yes & $\mathrm{No}$ & & Yes \\
\hline 2000 & No & Yes & Yes & No & & Yes \\
\hline 2002 & No & Yes & Yes & No & & Yes \\
\hline 2004 & Yes & Yes & Yes & No & & No \\
\hline
\end{tabular}




\section{Site Amenities}

$\begin{array}{cccccc}\begin{array}{c}\text { Program } \\ \text { Year }\end{array} & \begin{array}{c}\text { Covered } \\ \text { Bicycle Spaces }\end{array} & \begin{array}{c}\text { Uncovered } \\ \text { Bicycle Spaces }\end{array} & \begin{array}{c}\text { Clothes } \\ \text { Lockers }\end{array} & \text { Showers } & \begin{array}{c}\text { Non-SOV On-site } \\ \text { Loading/Unloading }\end{array} \\ 1999 & \text { Yes } & \text { Yes } & \text { No } & \text { No } & \text { Yes } \\ 2000 & \text { Yes } & \text { Yes } & \text { Yes } & \text { Yes } & \text { Yes } \\ 2002 & \text { No } & \text { Yes } & \text { Yes } & \text { Yes } & \text { No } \\ 2004 & \text { No } & \text { Yes } & \text { Yes } & \text { Yes } & \text { Yes }\end{array}$

\section{Financial Subsidies, Incentives or Allowances}

$\begin{array}{ccccc}\begin{array}{c}\text { Program } \\ \text { Year }\end{array} & \begin{array}{c}\text { Transit Subsidy } \\ \text { (Employee/Month) }\end{array} & \begin{array}{c}\text { Vanpool Subsidy } \\ \text { (Employee/Month) }\end{array} & \begin{array}{c}\text { Carpool Subsidy } \\ \text { (Employee/Month) }\end{array} & \begin{array}{c}\text { Walking Subsidy } \\ \text { (Employee/Month) }\end{array} \\ 1999 & \$ 10 & \$ 10 & 0 & 0 \\ 2000 & \$ 10 & \$ 10 & \$ 6.5 & 0 \\ 2002 & 0 & \$ 10 & \$ 8 & 0 \\ 2004 & \$ 11.25 & \$ 21.25 & \$ 11.25 & \$ 11.25 \\ \text { Program } & \text { Ferry Subsidy } & \text { Bicycling Subsidy } & \text { Other Stipend } & \\ \text { Year } & \text { (Employee/Month) } & \text { (Employee/Month } & \text { (Employee/Month) } & \\ 1999 & 0 & 0 & 0 & \\ 2000 & 0 & 0 & 0 & \\ 2002 & 0 & 0 & 0 & \\ 2004 & 0 & \$ 11.25 & & \end{array}$

\section{Fleet Vehicles and Special Programs}

\section{Employer provided vehicles availability}

$\begin{array}{cccccc}\begin{array}{c}\text { Program } \\ \text { Year }\end{array} & \begin{array}{c}\text { FV Guaranteed } \\ \text { Ride Home }\end{array} & \text { FV Vanpool } & \begin{array}{c}\text { FV } \\ \text { Carpool }\end{array} & \begin{array}{c}\text { FV Work- } \\ \text { Related Trips }\end{array} & \begin{array}{c}\text { FV Non-Work } \\ \text { Related Errands }\end{array} \\ 1999 & \text { No } & \text { No } & \text { No } & \text { No } & \text { No } \\ 2000 & \text { No } & \text { No } & \text { No } & \text { No } & \text { No } \\ 2002 & \text { No } & \text { No } & \text { No } & \text { Yes } & \text { No } \\ 2004 & \text { No } & \text { No } & \text { No } & \text { Yes } & \text { No }\end{array}$

\section{Other services availability}

$\begin{array}{cccc}\text { Program } & \text { Employer-Provided } & \text { Guaranteed Ride Home } & \text { Internal Match } \\ \text { Year } & \text { Shuttle } & \text { Program } & \text { Program } \\ 1999 & \text { No } & \text { Yes } & \\ 2000 & \text { No } & \text { Yes } & \\ 2002 & \text { No } & \text { Yes } & \text { Yes } \\ 2004 & \text { No } & \text { Yes } & \text { No }\end{array}$

\section{Mode Split and Vehicle Miles Traveled}

\begin{tabular}{|c|c|c|c|c|c|c|c|}
\hline $\begin{array}{l}\text { Program } \\
\text { Year }\end{array}$ & \multicolumn{2}{|c|}{$\begin{array}{l}\text { Num of Surveys } \\
\text { Distributed Num of }\end{array}$} & \multicolumn{2}{|c|}{ Total Reported } & $\begin{array}{l}\text { Driving } \\
\text { Alone }\end{array}$ & Carpooling & Vanpooling \\
\hline 1993 & 38 & & 1317 & & $80.8656 \%$ & $12.4525 \%$ & $0.0000 \%$ \\
\hline 1995 & 32 & & 1114 & & $76.1221 \%$ & $16.2478 \%$ & $0.4488 \%$ \\
\hline 1997 & 42 & & 1415 & & $81.2721 \%$ & $13.0742 \%$ & $0.4240 \%$ \\
\hline 1999 & 43 & & 1170 & & $78.6325 \%$ & $10.4274 \%$ & $2.3932 \%$ \\
\hline 2001 & 37 & & 1415 & & $73.3569 \%$ & $14.3463 \%$ & $2.1908 \%$ \\
\hline 2003 & 35 & & 1096 & & $72.7190 \%$ & $15.5109 \%$ & $0.0000 \%$ \\
\hline Program & Public & Bicycling & Walking & Othe & & hicle Miles & \\
\hline Year & Transit & & & & & Traveled & \\
\hline 1993 & $4.8595 \%$ & $1.0630 \%$ & $0.3037 \%$ & 0.455 & & 11.48 & \\
\hline 1995 & $4.4883 \%$ & $1.4363 \%$ & $0.7181 \%$ & 0.538 & & 10.69 & \\
\hline 1997 & $3.1802 \%$ & $1.2721 \%$ & $0.1413 \%$ & 0.636 & & 11.68 & \\
\hline 1999 & $5.2137 \%$ & $1.1966 \%$ & $0.5983 \%$ & 1.538 & & 11.38 & \\
\hline
\end{tabular}




$\begin{array}{llllll}2001 & 5.5124 \% & 2.6855 \% & 1.6961 \% & 0.2120 \% & 9.86 \\ 2003 & 6.2044 \% & 4.2883 \% & 0.8212 \% & 0.4562 \% & 9.84\end{array}$

\section{Compressed Work Week, Flex Time and Teleworking}

Policy (2000)

Flex Time

Employees must complete a flextime request if they wish to work hours other than 8:00am to $5: 00 \mathrm{pm}$. In granting flextime, supervisors must consider the need for staffing public service areas between 8 and 5 , whether granting the flextime will hamper the efficient delivery of services and the number of requests for flextime in their area. If there are more requests in a unit than can be granted, a system of drawing lots and rotation shall be instituted

Teleworking N No official policy, but various people telecommute on an "as needed or wanted" basis.

\section{Percentage of employees on Compressed Work}

\begin{tabular}{|c|c|c|c|c|}
\hline Program & Num of Surveys & Total Surveys & Percentage of Employees & Percentage of Employees \\
\hline Year & Distributed (Affected & Reported & On 5 Days/Week & On 3 Days/Week \\
\hline 1993 & 388 & 272 & $91.9118 \%$ & $0.0000 \%$ \\
\hline 1995 & 320 & 227 & $90.3084 \%$ & $0.8811 \%$ \\
\hline 1997 & 421 & 295 & $83.7288 \%$ & $0.0000 \%$ \\
\hline 1999 & 431 & 245 & $84.8980 \%$ & $0.8163 \%$ \\
\hline 2001 & 371 & 298 & $85.5705 \%$ & $0.0000 \%$ \\
\hline 2003 & 350 & 243 & $87.6543 \%$ & $0.4115 \%$ \\
\hline Program & Percentage of Employees & \multirow{2}{*}{\multicolumn{2}{|c|}{$\begin{array}{l}\text { Percentage of Employees } \\
\text { On } 7 \text { Days/Two Weeks }\end{array}$}} & \multirow{2}{*}{$\begin{array}{l}\text { Percentage of Employees } \\
\text { On } 9 \text { Days/Two Weeks }\end{array}$} \\
\hline Year & On 4 Days/Week & & & \\
\hline 1993 & $6.2500 \%$ & \multicolumn{2}{|c|}{$0.0000 \%$} & $.0000 \%$ \\
\hline 1995 & $4.8458 \%$ & \multicolumn{2}{|c|}{$0.0000 \%$} & $8811 \%$ \\
\hline 1997 & $7.1186 \%$ & \multicolumn{2}{|c|}{$0.0000 \%$} & $7627 \%$ \\
\hline 1999 & $6.9388 \%$ & \multicolumn{2}{|c|}{$0.0000 \%$} & $3061 \%$ \\
\hline 2001 & $10.0671 \%$ & \multicolumn{2}{|c|}{$0.0000 \%$} & $0268 \%$ \\
\hline 2003 & $6.5844 \%$ & \multicolumn{2}{|c|}{$0.0000 \%$} & $1152 \%$ \\
\hline
\end{tabular}

Percentage of employees on Telecommuting

\begin{tabular}{|c|c|c|c|c|c|}
\hline $\begin{array}{l}\text { Program } \\
\text { Year }\end{array}$ & \multicolumn{2}{|c|}{$\begin{array}{l}\text { Num of Surveys Distributed } \\
\text { (Num of Affected Employees) }\end{array}$} & $\begin{array}{l}\text { Total Surveys } \\
\text { Reported }\end{array}$ & $\begin{array}{l}\text { Total Percentage } \\
\text { of Telecommuters }\end{array}$ & $\begin{array}{l}1 \text { Days every } \\
\text { Two Weeks }\end{array}$ \\
\hline 1993 & \multicolumn{2}{|c|}{388} & 274 & $0.3650 \%$ & $0.0000 \%$ \\
\hline 1995 & \multicolumn{2}{|c|}{320} & 230 & $1.7391 \%$ & $1.3043 \%$ \\
\hline 1997 & \multicolumn{2}{|c|}{421} & 295 & $3.0508 \%$ & $2.0339 \%$ \\
\hline 1999 & \multicolumn{2}{|c|}{431} & 245 & $1.6327 \%$ & $1.2245 \%$ \\
\hline 2001 & \multicolumn{2}{|c|}{371} & 296 & $1.6892 \%$ & $1.3514 \%$ \\
\hline 2003 & \multicolumn{2}{|c|}{350} & 241 & $4.9793 \%$ & $2.0747 \%$ \\
\hline Program & 2 Days every & 3 Days & 4 Days every & 5 Days every & More than 5 \\
\hline Year & Two Weeks & every Two & Two Weeks & Two Weeks & Days every Two \\
\hline 1993 & $0.3650 \%$ & $0.0000 \%$ & $0.0000 \%$ & $0.0000 \%$ & $0.0000 \%$ \\
\hline 1995 & $0.4348 \%$ & $0.0000 \%$ & $0.0000 \%$ & $0.0000 \%$ & $0.0000 \%$ \\
\hline 1997 & $0.3390 \%$ & $0.0000 \%$ & $0.0000 \%$ & $0.0000 \%$ & $0.6780 \%$ \\
\hline 1999 & $0.4082 \%$ & $0.0000 \%$ & $0.0000 \%$ & $0.0000 \%$ & $0.0000 \%$ \\
\hline 2001 & $0.3378 \%$ & $0.0000 \%$ & $0.0000 \%$ & $0.0000 \%$ & $0.0000 \%$ \\
\hline 2003 & $1.2448 \%$ & $0.4149 \%$ & $0.4149 \%$ & $0.4149 \%$ & $0.4149 \%$ \\
\hline
\end{tabular}




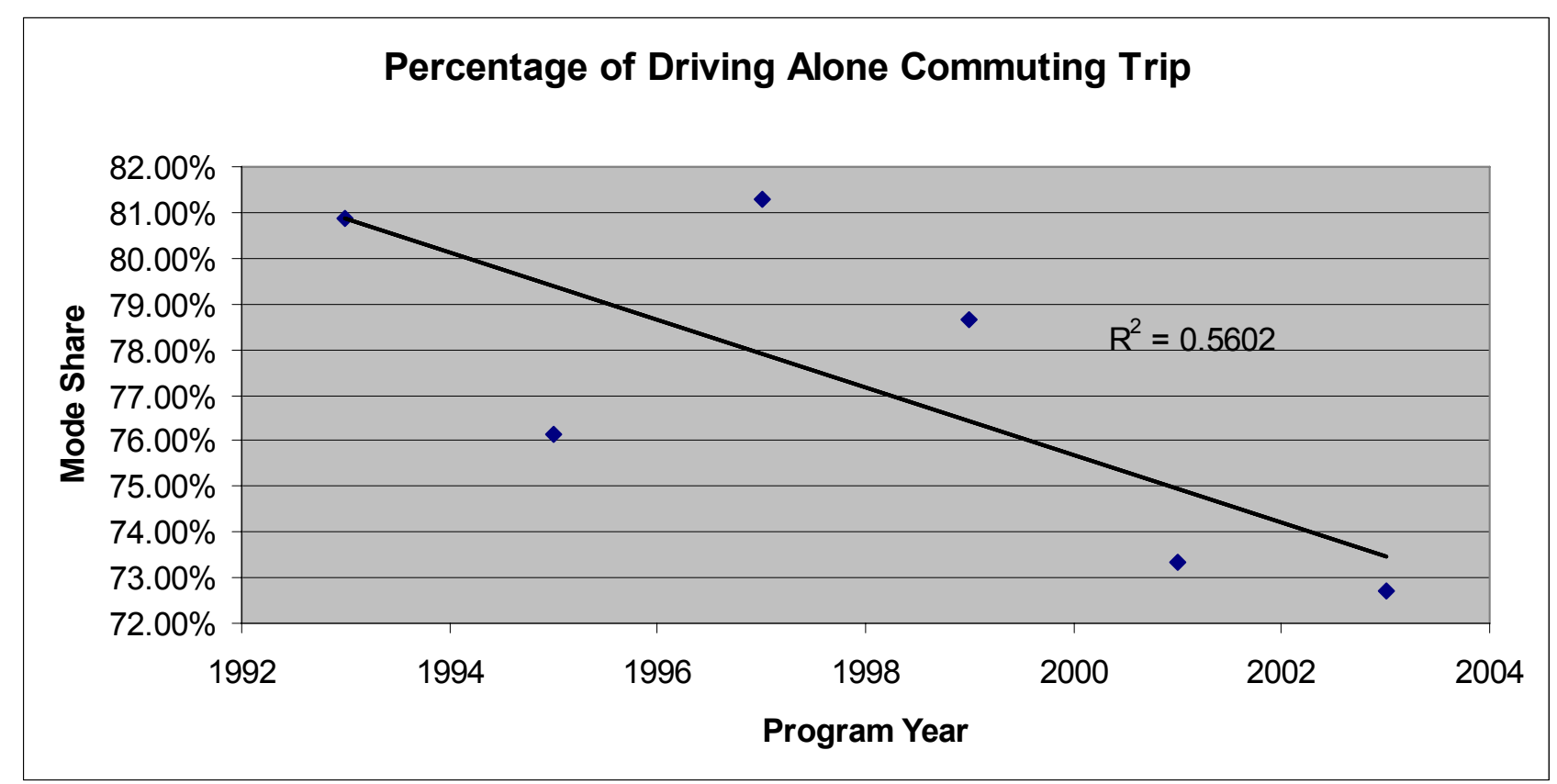

Figure 7: Percentage of Drive-Alone Commute Trips - Evergreen State College

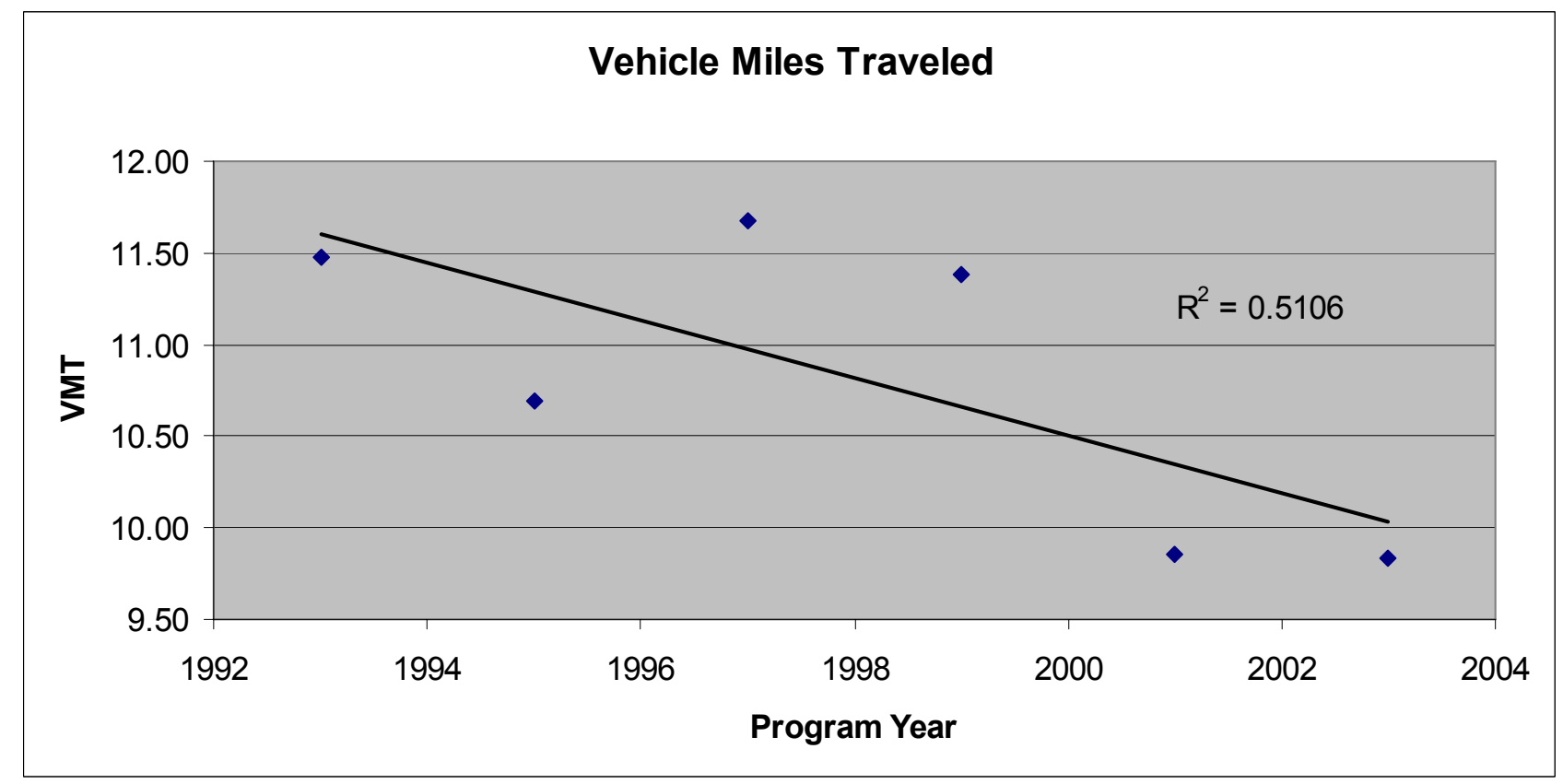

Figure 8: VMT - Evergreen State College 


\section{Mercer Human Resource Consulting}

Seattle, Washington

\section{Keys to Success}

Where state law or local ordinance mandates trip reduction program participation, employer program outcomes can be successful, even if an employer views a commute trip reduction (CTR) program as having no alignment with the mission of the organization. This is especially possible where there is limited parking and good transit service.

\section{Results and Cost}

Even though the organization provides free parking to highest level employees as a perk, the average one-way commute distance decreased from 4.9 to 3.5 vehicle miles traveled (VMT) between 1995 and 2003, with an R-square value greater than 0.5. This means that the observed VMT reduction was not a random occurrence. The growth in alternative modes was evidenced by an increase in mode share of transit from 49 percent in 1995 to 61 percent in 2003. Another ten percent carpooled in 2003 and over three percent walked. The Employee Transportation Coordinator (ETC) said their CTR program is simple because the company has been able and willing to pay for a blanket 100 percent subsidized bus pass for everyone who does not get free parking or subsidized carpool parking. As a result, the cost of the ETC's labor in administering the CTR program has been far less than if the program offered graduated levels of subsidy based upon various criteria. While the cost of the subsidized bus passes basically constitutes the cost of Mercer's CTR program, the ETC says that Mercer still would be paying something toward transit passes even without the CTR law in place but she does not know how much. Therefore, the cost of all bus passes is likely a high estimate of the cost of the CTR program to the company, which is estimated at over $\$ 127,000$ per year.5 The company also pays between $\$ 164,000$ and $\$ 181,500$ for parking (including the subsidized carpool spaces per year).

\section{Organizational Mission and Culture}

The Employee Transportation Coordinator (ETC) described the operation of their Commute Trip Reduction (CTR) program within a real-world business environment, where she must balance business objectives with legal compliance to the Washington State Law, controlling costs and recruiting and retaining employees. Despite these challenges and constraints, the program has still demonstrated a trend of continuous improvement in VMT reduction. The ETC would like

\footnotetext{
${ }^{5}$ The authors have attempted to estimate the cost of bus passes. Calculation based upon 206 affected employees -57 used SOV spaces $=149$ employees using alternative modes. 4 carpools at 2 persons each. 149 employees -8 carpoolers $=141$ employees who receive transit passes. $141 * \$ 70$ per month subsidy * 12 months $=\$ 118,440.8$ carpoolers $* \$ 91$ per month subsidy $* 12$ months $=\$ 8,736 . \$ 8,736+\$ 118,440=$ $\$ 127,176$ cost of transit subsidies. For simplicity of calculation, this did not incorporate cost of $\$ 98$ ferry subsidy per person per month. The number of ferry riders is unknown. Therefore, $\$ 127,176$ is likely a low estimate of the cost.
} 


\section{Mercer Human Resource Consulting}

Seattle, Washington

to see the future incorporation of a greater CTR program emphasis in her company. She cites examples of high profile worksite headquarters that people typically associate exemplifying the business ethos of Seattle. These include Amazon.com, Microsoft, and Starbucks that are reputably community-oriented. In contrast, Mercer is a global company for which just one office is located in Seattle; therefore, the impact of 'place' upon organizational culture arises from somewhere other than one specific location. While the ETC is assigned the legal requirement that Mercer conduct a CTR program, it is not seen by top management as necessary or complementary to business objectives. The ETC describes Mercer as not adverse to CTR, but rather as so focused on the client work that the CTR program is always considered secondary. The ETC said that Mercer's corporate headquarters in New York has never provided any policies regarding parking but now is considering practicalities associated with the cost of parking to the organization more so than in the past.

The mission of Mercer Human Resource Consulting includes “...making a positive impact on the world ...by enhancing the financial and retirement security, health, productivity and employment relationships of the global workforce." Mercer wants to be the employer of choice. The ETC describes this desire to not only be the best in their industry but also to attract and retain the best employees through benefits programs. The nature of the work accomplished at Mercer includes frequent interaction among employees. The ETC describes the business philosophy of top management as seeing the CTR program as unrelated to the mission of the organization; therefore, legal compliance is the primary goal of CTR program participation.

Mercer Human Resource Consulting provides professional consulting services in human resources, related financial advice, products and services. The ETC describes Mercer as coexisting in the community without the need for much interaction. They have several very large clients locally. Mercer is well known and has not needed to rely strongly on advertising. However, Mercer does interact with the community through charitable activities. The work of Mercer is accomplished from multiple worksite locations and these sites are decentralized and managed individually at each worksite. This case study pertains to the office in the downtown central business district in a building occupied by multiple employers.

The ETC thinks that someday the CTR program will be better integrated into the business objectives of the company, moving from compliance to 'green' business objectives. However, there are challenges ahead. For example, the ETC wants to restart a former Flexcar program for employees to enable employees to drive to client meetings. Flexcar has restructured their program price offerings from a set cost per hour to a set price per month which pays for some number of miles. It has challenged the ETC to convince management to reinstitute Flexcar for employees. Management wants to see a cost comparison between the old Flexcar plan usage and the new proposed one, but it is not possible to compare the cost of how many people used the old plan in the past with the cost of how many people are likely to use the new plan. 


\section{Mercer Human Resource Consulting}

Seattle, Washington

\section{Employee Characteristics}

Employees are described as white-collar professionals and approximately 95 percent work full time. There are a total of 230 employees and 206 affected employees, making participation in the Washington State CTR program a requirement. While the number of employees has risen from 195 to 230 since 2005, the number of parking spaces leased by Mercer has stayed the same during that time. Employees represent a wide variety of commuting conditions. Some take the ferry. While the CTR program survey data indicates no bicyclists, the ETC has seen a few people carrying their bicycles and change of clothes into the building. Those who have bicycled have not reported their alternative commute activity to the ETC. This might suggest that some employees are motivated to use a commute alternative for reasons other than worksite compliance.

Many people who work there at higher management levels and who are not restricted financially would rather just drive. Therefore, the responsibility for implementing the CTR program is not evenly distributed across all employees. Those who earn the most are somewhat insulated from the intent and effects of the CTR program. All in all, the ETC feels that while some individual employees at Mercer might disagree with the intent and effects of the CTR program, the program does not conflict with the organization and works well with their current situation.

With the recent increases in fuel prices, the ETC said she was surprised that not more people began to take transit. Car drivers are willing to pay the price to drive. The ETC said the most important reason why those people who could ride transit do not is to determine their own schedule and not be constrained to a bus schedule. Personal preferences also play a part. Some people would rather not have to sit next to another person. The ETC observes basic unwillingness to try transit because of personal inflexibility. The ETC also describes 8 carpools of two persons each. The ETC said that for some employees, it is so important to them not to take the bus that they have formed carpools.

\section{External Conditions}

The adjacent road system is a dense grid of streets and major highways. Traffic conditions are described as 'gridlock' surrounding the worksite at peak commute times and these conditions appear to have stayed the same in the past year. The ETC said that "Commuting is extremely terrible in Seattle." Commuting from the south is least difficult but due to the water, there are several bridges that become bottlenecks. The ETC also described Seattle-area development as widely dispersed, and while a majority of employees ride buses, many of them must first drive some distance from home to a park-and-ride lot to access a transit stop.

The worksite is within $1 / 4$ mile of a bus stop and the ETC describes service frequency to the worksite as "Dozens of buses from all surrounding areas at various times." The ETC rides the bus everyday. She hears comments about bus service during community meetings she attends 


\section{Mercer Human Resource Consulting}

Seattle, Washington

and from people at the office who express their opinions about bus service to her. The ETC says that for the most part, bus riders are happy with bus service; it is generally accessible to everybody. The ETC said that there are some employees who choose to work long hours in the office. Later in the evening transit becomes less reliable.

\section{On-site Amenities}

There are sidewalks, restaurants, shopping and banking onsite and within a few blocks of the worksite. The worksite location also offers both uncovered and covered bicycle parking, although the few who bicycle have been observed by the ETC to carry their bicycles into the building, suggesting security is a need.

\section{Commute Trip Reduction Program}

The provision of free parking has historically been a perk offered in employee recruiting; however, due to parking availability constraints imposed by the office property, free parking to higher level positions is no longer included in hiring letters and is only offered if available. The office building property management allocates onsite parking spaces to tenants based upon leased square footage. Presently, Mercer leases 4 onsite parking spaces for carpools and 21 additional onsite parking spaces assigned to highest level employees. These 25 spaces are leased by Mercer for $\$ 260$ per space per month and are provided free to highest level employees. Mercer also leases off-site parking spaces in two garages at \$220 and \$260 per space per month for a total of 36 off-site spaces. While the County has placed a cap on their parking, this cap has enabled Mercer to assign parking as a perk to employees based on higher hierarchical level, top performance in the organization and on the need to drive to client meetings. The need to attend off-site meetings during the day is associated with the higher level positions. It is not rare for a client to request a Mercer representative to meet with them at the client's office. Mercer has reimbursed employees for taxi fare. Several Mercer clients are very large organizations that cannot be located downtown due to their size and need for a campus. Some employees attend at least one off-site meeting per day. Because Mercer wanted to be able to offer free parking to highly valued employees and because the CTR Program is adverse to this practice, Mercer responded by providing 100 percent subsidized bus passes to the rest of the staff. Mercer also provides a reimbursement for parking for employees who must use their own vehicle to travel to client meetings and who normally qualify for company-paid parking but who prefer to commute by bus.

The CTR program includes a free transit pass worth $\$ 70$ per employee per month or a free ferry pass worth $\$ 98$ per employee per month or a carpool subsidy of $\$ 91$ per employee per month, and a guaranteed ride home program. The cost to carpooling employees of each carpool space is $\$ 182$ per month because Mercer provides a subsidy of $\$ 78$ per space per month for each carpool. Because Mercer has paid for the carpool parking space, all carpools using that space must be formed among Mercer employees. Because Mercer pays 100 percent of the transit subsidy, 


\section{Mercer Human Resource Consulting}

Seattle, Washington

employees do not have an incentive to form carpools to save costs. Bus riding is not a time savings though. There is time waiting for the bus. For those suburbs closer to the downtown, buses on local routes stop every two blocks. The main reason people ride the bus is cost savings. The people at lower levels in the firm who get paid less and are not offered free parking also cannot afford to pay for parking. The ETC also said that roughly half of employees have laptops, many of whom take work home. Carrying a laptop and papers on the bus is not convenient but bus riders will do it if necessary.

Employees all work the same general shift but flex time and compressed work week schedules are available with supervisor approval. The ETC said that management has been flexible with allowing employees flex time and telework arrangements. The percentage of employees using compressed work week was close to five percent in 2003. Similarly, the number of employees who teleworked increased from one percent to almost 7 percent in 2003 with most teleworkers working remotely two days every two weeks. The ETC said that the use of flex time and telework has increased in the past year. Part of this is attributed to the difficulty of commuting in Seattle.

Program promotion activities to employees include distributing summaries of CTR program information, orientation information for new employees, posting materials on an employee bulletin board and posting reminders by company intranet. The ETC says that the employees know the transportation benefits are there and anything more than occasional reminders would be unnecessary.

The ETC said that the CTR Program essentially runs itself without much effort on her part. The program is simple and as generous as the company can be. There are issues that come up, for example, determining who on the waiting list gets assigned a parking space. But the presence of the transit subsidy essentially carries the program.

\section{Employee Transportation Coordinator}

The Mercer corporate headquarters requires offices to be located in the downtown core for visibility and access to clients. The ETC said Mercer wants to be located in a high rise building. Mercer is moving next year to co-locate with its sibling companies. There were a limited number of sites to choose from. The ETC asserted to her colleagues that one potential site lacked adequate bus service and as a result the site was eliminated as a possibility. Bus access was a significant determinant in selection of a future new worksite and the ETC was influential in this assessment.

The ETC is the Office Administrator in the department of Operations Administration. The ETC initially worked for another company when the CTR law was enacted and the company got involved because it was a requirement. When the ETC began working for Mercer after her company was purchased, the person in charge of the CTR program was in Human Resources and did not want to run the program anymore. She was assigned the duties of the ETC because her 


\section{Mercer Human Resource Consulting}

\section{Seattle, Washington}

other duties were considered related. The ETC has been serving in this capacity for nine years and has a separate office. The ETC has completed a training course, spends an average of 2 hours per week on CTR activities and thinks the meetings of the ETC network are worthwhile. ETC duties are not explicitly included as part of the Office Administrator's written job description. She is a mid-level manager of many non-client-related responsibilities. These include facilities manager, administration manager and supervisor of 9 office services people and 25 administrative assistants. Mercer recently outsourced all Information Technology (IT) operations and she is the local in-house IT coordinator as well.

She said that as a manager she does have some power to influence the implementation of the CTR program but she also has the responsibility to figure out what gets cut during times of budgetary constraints and how those cuts best benefit the overall Mercer program. The ETC said that in a way the CTR program benefits Mercer in the sense that it helps Mercer to exercise fiscal discipline in operating within budgetary constraints so that they are not wildly giving out free parking spaces.

She also said that it does help when someone at corporate headquarters in New York tells her she is spending too much money on transportation benefits, she can respond that there is a law in Washington State that requires companies to provide balanced transportation options to the staff. Top management listens to her recommendations because this is an area that not many understand or think about so her input counts. The only support the ETC says she needs from her company to carry out the CTR program is the transit subsidy.

From the perspective of King County's needs, the ETC says that the most important thing she does is submit the required surveys and reports on time and complete. She makes every effort to ensure that every employee completes the survey. If they do not, she sits with them at their desks and helps them complete the surveys. She believes this is important because it is the law. From the perspective of employee needs, the ETC always tries to be available to help them with their transit questions. If there is something happening in the downtown, such as a demonstration, she sends emails with information about how to avoid commuting difficulties. She monitors traffic information and gives help whenever she can. 


\section{Organization Information (2005)}

\section{Mercer Human Resource Consulting}

Seattle, WA

Website: www.mercer.com

Primary Business: Professional/Personal

Non-profit organization? No

Total Employees:

Affected Employees:

Is the CTR program subject to collective bargaining? No

Does this worksite have multiple shifts?

No

Shifts description:

N/A

CTR program contact:

David Lantry

King County Metro

400 Yesler Way, MS YES-TR-0650, Seattle, WA 98104

Phone: (206) 684-1139

Email: david.lantry@metrokc.gov

\section{Worksite Characteristics (2005)}

$\begin{array}{cccccc}\text { Bus stop(s) } & \text { Bike lane } & \text { Sidewalks } & \text { Restaurants } & \text { Shopping } & \text { Bank } \\ \text { Availability } & \text { Availability } & \text { Availability } & \text { Availability } & \text { Availability } & \text { Availability } \\ \text { Within } 1 / 4 \text { mile } & \text { Not available } & \text { Onsite } & \text { Onsite } & \text { Onsite } & \text { Onsite }\end{array}$

\section{Program Narrative (2001)}

Our CTR program includes the following: company paid free bus or ferry pass offered to all employees, guaranteed ride home policy, flex time and compressed work schedules, employees who normally qualify for company-paid parking, but prefer to commute by bus are reimbursed for parking when they must use their own vehicle to travel to client meetings.

\section{Worksite Parking and Parking Management Information}

\section{Parking management and monitoring (2005)}

21 spaces ( $\$ 260$ ea.) in our building are assigned to our highest level employees. 36 offsite spaces (2 garages, $\$ 220$ \& $\$ 260$ ea.) are assigned to employees by level \& by need (client meetings). 4 additional onsite parking spaces are for carpools (\$182 ea.).

\section{Parking}

\begin{tabular}{|c|c|c|c|c|}
\hline $\begin{array}{l}\text { Program } \\
\text { Year }\end{array}$ & $\begin{array}{l}\text { Total Num of } \\
\text { Employees }\end{array}$ & $\begin{array}{l}\text { Onsite Parking } \\
\text { Spaces }\end{array}$ & $\begin{array}{l}\text { Offsite Parking } \\
\text { Spaces }\end{array}$ & $\begin{array}{l}\text { Leased Onsite } \\
\text { Parking Spaces }\end{array}$ \\
\hline 1999 & 203 & 17 & 33 & 17 \\
\hline 2000 & 208 & 17 & 33 & 17 \\
\hline 2001 & 225 & & & 20 \\
\hline 2003 & 223 & 21 & 35 & 21 \\
\hline 2005 & 195 & 25 & 36 & 25 \\
\hline Program & Leased Offsite & \multirow{2}{*}{\multicolumn{2}{|c|}{$\begin{array}{l}\text { Leased Onsite Parking } \\
\text { Price (Space/Month) }\end{array}$}} & Leased Offsite Parking \\
\hline Year & Parking Spaces & & & Price (Space/Month) \\
\hline 1999 & 33 & \multicolumn{2}{|c|}{$\$ 200$} & $\$ 180$ \\
\hline 2000 & 33 & \multicolumn{2}{|c|}{$\$ 225$} & $\$ 180$ \\
\hline 2001 & 33 & \multicolumn{2}{|c|}{$\$ 260$} & $\$ 220$ \\
\hline 2003 & 35 & \multicolumn{2}{|c|}{$\$ 260$} & $\$ 260$ \\
\hline 2005 & 36 & \multicolumn{2}{|c|}{$\$ 260$} & $\$ 260$ \\
\hline
\end{tabular}




\section{Parking management}

\begin{tabular}{|c|c|c|c|c|c|c|}
\hline Program & \multirow{2}{*}{$\begin{array}{l}\text { Owned Onsite } \\
\text { Parking Charge }\end{array}$} & Owned Offsite & & Leased Onsite & \multicolumn{2}{|c|}{ Leased Offsite } \\
\hline Year & & Parking Charg & & Parking Charge & & king Charge \\
\hline 1999 & $\begin{array}{l}0 \text { (Owned or } \\
\text { Leased) }\end{array}$ & $\begin{array}{c}0 \text { (Owned or } \\
\text { Leased) }\end{array}$ & & $\begin{array}{l}\text { (Owned or } \\
\text { Leased) }\end{array}$ & & $\begin{array}{l}\text { Dwned or } \\
\text { eased) }\end{array}$ \\
\hline 2000 & $\begin{array}{c}0 \text { (Owned or } \\
\text { Leased) }\end{array}$ & $\begin{array}{l}0 \text { (Owned or } \\
\text { Leased) }\end{array}$ & & $\begin{array}{l}\text { (Owned or } \\
\text { Leased) }\end{array}$ & & $\begin{array}{l}\text { Wwned or } \\
\text { eased) }\end{array}$ \\
\hline 2001 & $\begin{array}{c}0 \text { (Owned or } \\
\text { Leased) }\end{array}$ & $\begin{array}{c}0 \text { (Owned or } \\
\text { Leased) }\end{array}$ & & $\begin{array}{l}\text { (Owned or } \\
\text { Leased) }\end{array}$ & & $\begin{array}{l}\text { wned or } \\
\text { eased) }\end{array}$ \\
\hline 2003 & 0 & 0 & & 0 & & 0 \\
\hline 2005 & 0 & 0 & & 0 & & 0 \\
\hline Program & Carpool & Carpool Parking & Vanpool & Vanpool & & Reduced SOV \\
\hline Year & Parking Spaces & Charge & Parking & Charge (Spa & onth) & Parking Space \\
\hline 1999 & 326 & $\$ 154$ & 4 & 0 & & 0 \\
\hline 2000 & 226 & $\$ 160$ & 4 & 0 & & 0 \\
\hline 2001 & 226 & $\$ 160$ & 4 & 0 & & 0 \\
\hline 2003 & $\begin{array}{c}0 \text { (Carpool \& } \\
\text { Vanpool) }\end{array}$ & $\$ 182$ & $\begin{array}{c}0 \text { (Carpool \& } \\
\text { Vanpool) }\end{array}$ & \& & & 0 \\
\hline 2005 & $\begin{array}{c}4 \text { (Carpool \& } \\
\text { Vanpool) }\end{array}$ & 0 & 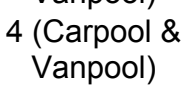 & $\&$ & & 0 \\
\hline
\end{tabular}

\section{Program Promotion}

\section{General (2005)}

Is the ETC's name, location and telephone number prominently displayed at this Yes

Displayed where? employees bulletin board and internal website

Has the ETC completed a program developer/ETC training course?

On average, how many hours per week does the ETC spend on CTR activities?

Does the ETC have an active worksite committee to assist with the CTR

2

No

\section{Program promotion}

\begin{tabular}{|c|c|c|c|c|c|c|}
\hline $\begin{array}{c}\text { Program } \\
\text { Year }\end{array}$ & Distribute & \multicolumn{3}{|c|}{ Provide CTR Program } & $\begin{array}{c}\text { Post } \\
\text { Materials }\end{array}$ & $\begin{array}{l}\text { Give Manage } \\
\text { Presentation }\end{array}$ \\
\hline 1999 & Yes & & Yes & & Yes & No \\
\hline 2000 & Yes & & Yes & & Yes & No \\
\hline 2001 & Yes & & Yes & & Yes & No \\
\hline 2003 & Yes & & Yes & & Yes & No \\
\hline 2005 & Yes & & Yes & & Yes & No \\
\hline Program & Give & Conduct & Publish & Dist & bute & Distribute \\
\hline Year & Employees & CTR Events & CTR Articles & Informe & on with & Ridematch \\
\hline 1999 & No & No & & $\mathrm{N}$ & & No \\
\hline 2000 & No & No & No & $\mathrm{N}$ & & No \\
\hline 2001 & No & No & No & $\mathrm{N}$ & & No \\
\hline 2003 & No & No & No & $\mathrm{N}$ & & No \\
\hline 2005 & No & No & No & $\mathrm{N}$ & & No \\
\hline
\end{tabular}

\section{Site Amenities}

$\begin{array}{cccccc}\begin{array}{c}\text { Program } \\ \text { Year }\end{array} & \begin{array}{c}\text { Covered } \\ \text { Bicycle Spaces }\end{array} & \begin{array}{c}\text { Uncovered } \\ \text { Bicycle Spaces }\end{array} & \begin{array}{c}\text { Clothes } \\ \text { Lockers }\end{array} & \text { Showers } & \begin{array}{c}\text { Non-SOV On-site } \\ \text { Loading/Unloading }\end{array} \\ 1999 & \text { Yes } & \text { Yes } & \text { No } & \text { No } & \text { Yes } \\ 2000 & \text { Yes } & \text { Yes } & \text { No } & \text { No } & \\ 2001 & \text { Yes } & \text { Yes } & \text { No } & \text { No } & \text { Yes } \\ 2003 & \text { Yes } & \text { Yes } & \text { No } & \text { No } & \text { No } \\ 2005 & \text { Yes } & \text { Yes } & \text { No } & \text { No } & \end{array}$




\section{Financial Subsidies, Incentives or Allowances}

$\begin{array}{ccccc}\begin{array}{c}\text { Program } \\ \text { Year }\end{array} & \begin{array}{c}\text { Transit Subsidy } \\ \text { (Employee/Month) }\end{array} & \begin{array}{c}\text { Vanpool Subsidy } \\ \text { (Employee/Month) }\end{array} & \begin{array}{c}\text { Carpool Subsidy } \\ \text { (Employee/Month) }\end{array} & \begin{array}{c}\text { Walking Subsidy } \\ \text { (Employee/Month) }\end{array} \\ 2099 & \$ 56.04 & 0 & 0 & 0 \\ 2000 & \$ 72 & 0 & \$ 125 & 0 \\ 2003 & \$ 65 & 0 & 0 & 0 \\ 2005 & \$ 72 & 0 & \$ 91 & 0 \\ \text { Program } & \text { Ferry Subsidy } & \text { Bicycling Subsidy } & \text { Other Stipend } & \\ \text { Year } & \text { (Employee/Month) } & \text { (Employee/Month } & \text { (Employee/Month) } \\ 1999 & \$ 50.30 & 0 & 0 & \\ 2000 & \$ 59.25 & 0 & 0 & \\ 2001 & \$ 87 & 0 & 0 & \\ 2003 & \$ 105 & 0 & 0 & \\ 2005 & \$ 98 & 0 & 0 & \end{array}$

\section{Fleet Vehicles and Special Programs}

\section{Employer provided vehicles availability}

$\begin{array}{cccccc}\begin{array}{c}\text { Program } \\ \text { Year }\end{array} & \begin{array}{c}\text { FV Guaranteed } \\ \text { Ride Home }\end{array} & \text { FV Vanpool } & \begin{array}{c}\text { FV } \\ \text { Carpool }\end{array} & \begin{array}{c}\text { FV Work- } \\ \text { Related Trips }\end{array} & \begin{array}{c}\text { FV Non-Work } \\ \text { Related Errands }\end{array} \\ 1999 & \text { No } & \text { No } & \text { No } & \text { No } & \text { No } \\ 2000 & \text { No } & \text { No } & \text { No } & \text { No } & \text { No } \\ 2001 & \text { No } & \text { No } & \text { No } & \text { No } & \text { No } \\ 2003 & \text { No } & \text { No } & \text { No } & \text { No } & \text { No } \\ 2005 & \text { No } & \text { No } & \text { No } & \text { No } & \text { No }\end{array}$

\section{Other services availability}

$\begin{array}{cccc}\text { Program } & \text { Employer-Provided } & \text { Guaranteed Ride Home } & \text { Internal Match } \\ \text { Year } & \text { Shuttle } & \text { Program } & \\ 1999 & \text { No } & \text { Yes } & \\ 2000 & \text { No } & \text { Yes } & \\ 2001 & \text { No } & \text { Yes } & \\ 2003 & \text { No } & \text { Yes } & \text { No } \\ 2005 & \text { No } & \text { Yes } & \text { No }\end{array}$

\section{Mode Split and Vehicle Miles Traveled}

\begin{tabular}{|c|c|c|c|c|c|c|c|}
\hline $\begin{array}{l}\text { Program } \\
\text { Year }\end{array}$ & \multicolumn{2}{|c|}{$\begin{array}{l}\text { Num of Surveys } \\
\text { Distributed (Num of }\end{array}$} & \multicolumn{2}{|c|}{ Total Reported } & $\begin{array}{l}\text { Driving } \\
\text { Alone }\end{array}$ & Carpooling & Vanpooling \\
\hline 1995 & 114 & & 435 & & $30.1149 \%$ & $15.6322 \%$ & $0.0000 \%$ \\
\hline 1997 & 130 & & 491 & & $26.0692 \%$ & $15.0713 \%$ & $0.0000 \%$ \\
\hline 1999 & 190 & & 711 & & $30.0985 \%$ & $8.5795 \%$ & $0.0000 \%$ \\
\hline 2001 & 211 & & 780 & & $24.7436 \%$ & $4.7436 \%$ & $0.0000 \%$ \\
\hline 2003 & 212 & & 772 & & $25.2591 \%$ & $10.3627 \%$ & $0.0000 \%$ \\
\hline Program & Public & Bicycling & Walking & Other & & hicle Miles & \\
\hline Year & Transit & & & & & Traveled & \\
\hline 1995 & $48.7356 \%$ & $0.6897 \%$ & $4.8276 \%$ & 0.0000 & & 4.83 & \\
\hline 1997 & $51.7312 \%$ & $0.8147 \%$ & $3.2587 \%$ & 3.0550 & & 4.55 & \\
\hline 1999 & $51.7581 \%$ & $0.0000 \%$ & $4.3601 \%$ & 5.2039 & & 4.75 & \\
\hline 2001 & $67.3077 \%$ & $0.0000 \%$ & $2.0513 \%$ & 1.1538 & & 3.31 & \\
\hline 2003 & $61.1399 \%$ & $0.0000 \%$ & $3.2383 \%$ & 0.0000 & & 3.49 & \\
\hline
\end{tabular}




\section{Compressed Work Week, Flex Time and Teleworking}

\section{Policy (2001)}

Flex Time

Supervisor will approve and adjust work schedules whenever possible as requested by employees.

Teleworking There are times when employees have a need to occasionally work from home or some other remote site.

\section{Percentage of employees on Compressed Work}

\begin{tabular}{ccccc}
$\begin{array}{c}\text { Program } \\
\text { Year }\end{array}$ & $\begin{array}{c}\text { Num of Surveys } \\
\text { Distributed (Affected }\end{array}$ & $\begin{array}{c}\text { Total Surveys } \\
\text { Reported }\end{array}$ & $\begin{array}{c}\text { Percentage of Employees } \\
\text { On 5 Days/Week }\end{array}$ & $\begin{array}{c}\text { Percentage of Employees } \\
\text { On 3 Days/Week }\end{array}$ \\
1995 & 114 & 88 & $98.8636 \%$ & $0.0000 \%$ \\
1997 & 130 & 100 & $96.0000 \%$ & $0.0000 \%$ \\
1999 & 190 & 145 & $95.1724 \%$ & $0.6897 \%$ \\
2001 & 211 & 171 & $93.5673 \%$ & $0.5848 \%$ \\
2003 & 212 & 163 & $94.4785 \%$ & $0.0000 \%$ \\
Program & Percentage of Employees & Percentage of Employees & Percentage of Employees \\
Year & On 4 Days/Week & On 7 Days/Two Weeks & On 9 Days/Two Weeks \\
1995 & $1.1364 \%$ & \multicolumn{2}{c}{$0.0000 \%$} & $0.0000 \%$ \\
1997 & $4.0000 \%$ & $0.0000 \%$ & $0.0000 \%$ \\
1999 & $2.7586 \%$ & $0.0000 \%$ & $0.6897 \%$ \\
2001 & $5.2632 \%$ & $0.0000 \%$ & & $0.0000 \%$ \\
2003 & $3.6810 \%$ & $0.0000 \%$ & & $1.2270 \%$
\end{tabular}

\section{Percentage of employees on Telecommuting}

\begin{tabular}{|c|c|c|c|c|c|}
\hline $\begin{array}{l}\text { Program } \\
\text { Year }\end{array}$ & \multicolumn{2}{|c|}{$\begin{array}{l}\text { Num of Surveys Distributed } \\
\text { (Num of Affected Employees) }\end{array}$} & $\begin{array}{l}\text { Total Surveys } \\
\text { Reported }\end{array}$ & $\begin{array}{l}\text { Total Percentage } \\
\text { of Telecommuters }\end{array}$ & $\begin{array}{l}1 \text { Days every } \\
\text { Two Weeks }\end{array}$ \\
\hline 1995 & \multicolumn{2}{|c|}{114} & 88 & $1.1364 \%$ & $1.1364 \%$ \\
\hline 1997 & \multicolumn{2}{|c|}{130} & 101 & $0.0000 \%$ & $0.0000 \%$ \\
\hline 1999 & \multicolumn{2}{|c|}{190} & 145 & $5.5172 \%$ & $1.3793 \%$ \\
\hline 2001 & \multicolumn{2}{|c|}{211} & 170 & $8.8235 \%$ & $2.3529 \%$ \\
\hline 2003 & \multicolumn{2}{|c|}{212} & 160 & $6.8750 \%$ & $0.0000 \%$ \\
\hline Program & 2 Days every & 3 Days & 4 Days every & 5 Days every & More than 5 \\
\hline Year & Two Weeks & every Two & Two Weeks & Two Weeks & Days every Two \\
\hline 1995 & $0.0000 \%$ & $0.0000 \%$ & $0.0000 \%$ & $0.0000 \%$ & $0.0000 \%$ \\
\hline 1997 & $0.0000 \%$ & $0.0000 \%$ & $0.0000 \%$ & $0.0000 \%$ & $0.0000 \%$ \\
\hline 1999 & $3.4483 \%$ & $0.0000 \%$ & $0.0000 \%$ & $0.0000 \%$ & $0.6897 \%$ \\
\hline 2001 & $3.5294 \%$ & $0.0000 \%$ & $1.7647 \%$ & $0.0000 \%$ & $1.1765 \%$ \\
\hline 2003 & $5.6250 \%$ & $0.0000 \%$ & $0.0000 \%$ & $0.0000 \%$ & $1.2500 \%$ \\
\hline
\end{tabular}




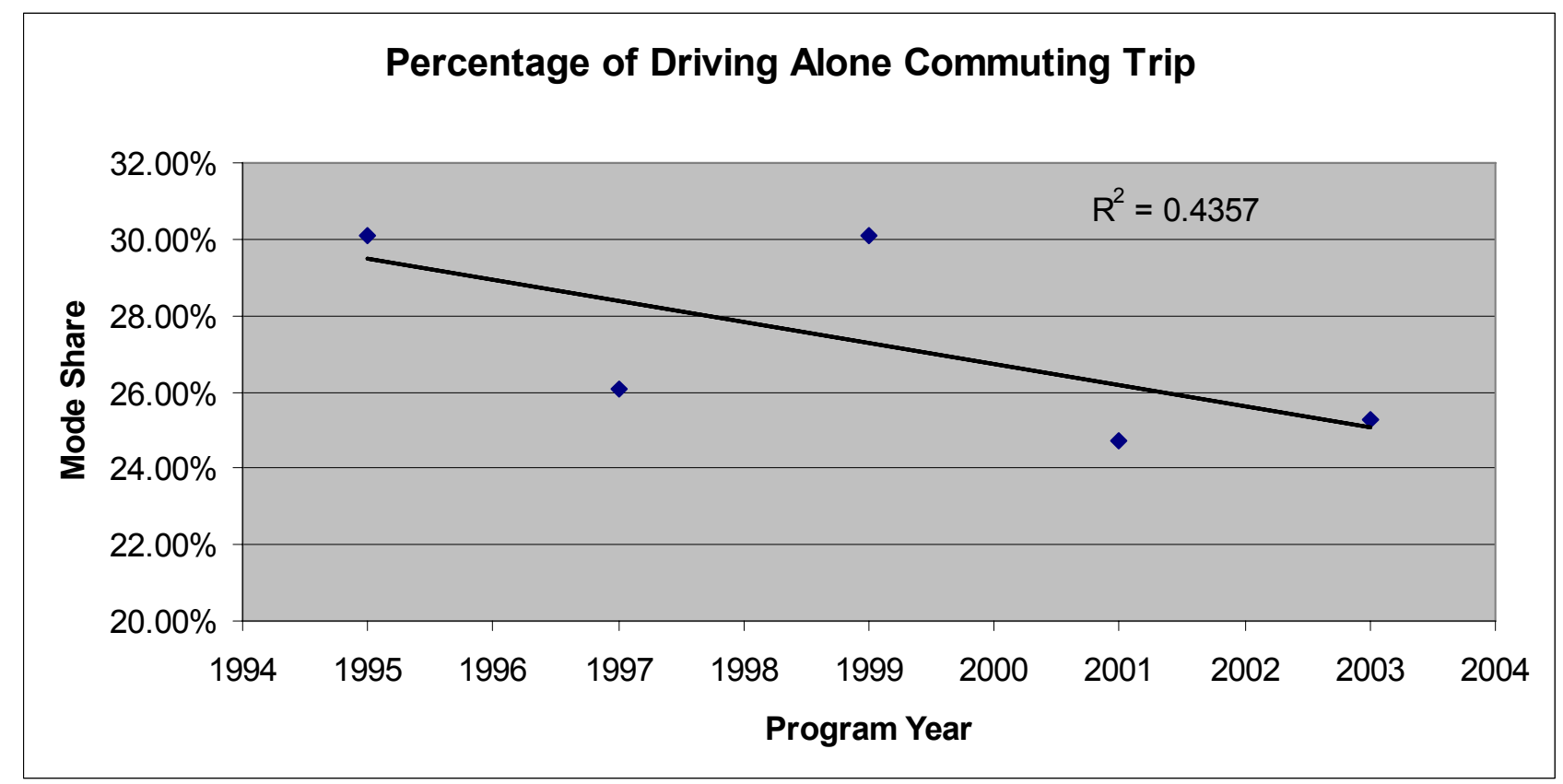

Figure 9: Percentage of Drive-Alone Commute Trips - Mercer HR Consulting

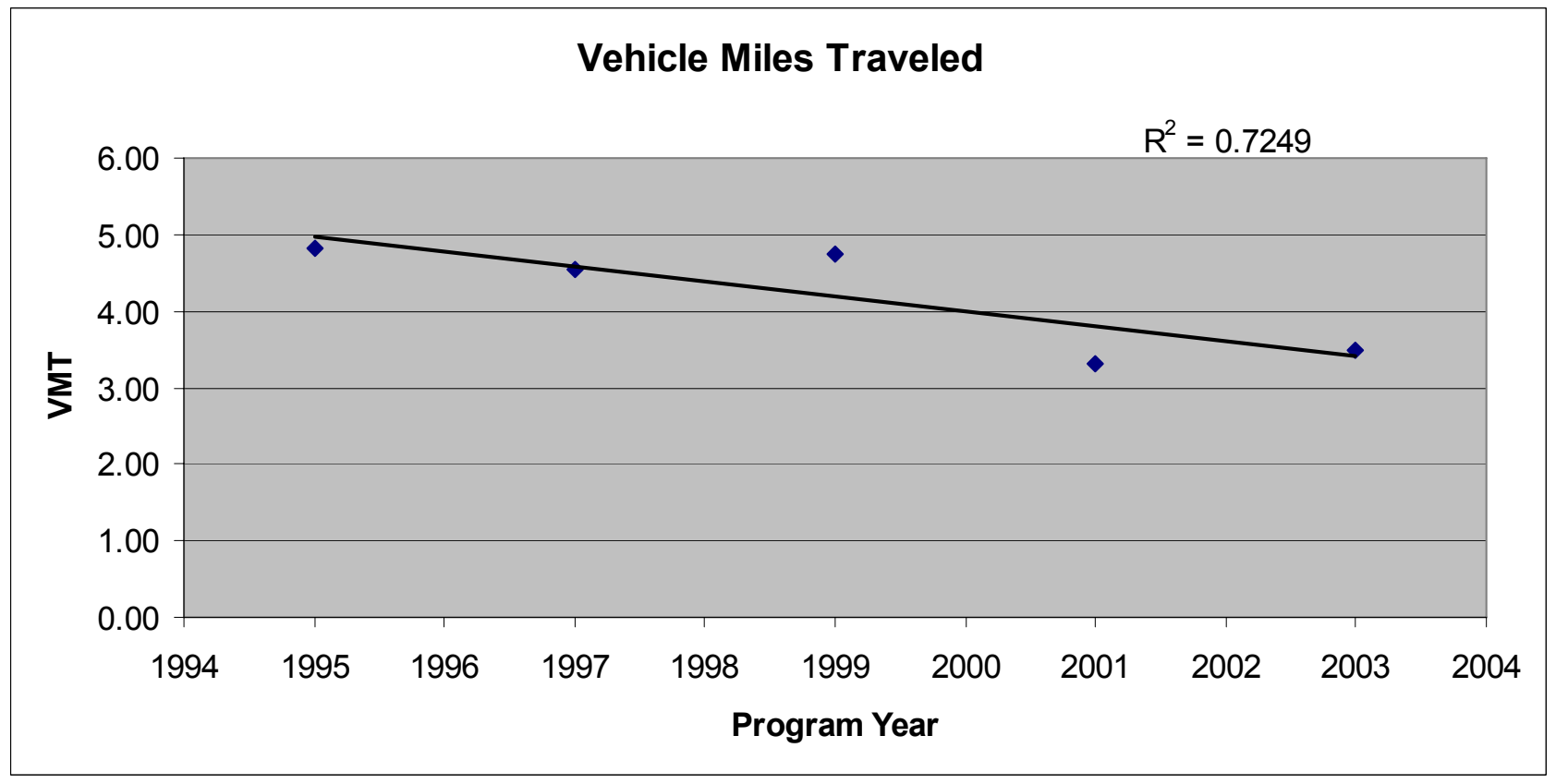

Figure 10: VMT - Mercer HR Consulting 


\section{Microsoft Corporation}

Issaquah, WA

\section{Keys to Success}

The Microsoft Corporation worksite is located on a suburban campus surrounded by external traffic congestion conditions. While local transit serving the worksite is not optimal, high occupancy vehicle (HOV) lanes have encouraged carpooling. Microsoft has committed abundant labor and capital resources to operate a commute trip reduction (CTR) program, called 'Microsoft Commute'. The program provides an internal web-based ridematching service that receives 30-40 emails per day from people looking for ad hoc ridesharing opportunities and wanting to take advantage of the State Route $520 \mathrm{HOV}$ lanes. Microsoft also reduces the need for a car onsite by operating a shuttle that circulates inside the campus and has provided 50,000 trips per month. Organizational culture allows flex time for employees to travel outside the peak hours of congestion. A large number of employees start the work day after 10 a.m. and work until 9 p.m.

\section{Results and Cost}

Between 1995 and 2003, driving alone has decreased from 91 percent to 85 percent, carpooling has increased from 7 percent to 12 percent and the remaining three percent who use transportation alternatives is a combination of vanpooling, public transit use, bicycling and walking. The results of this CTR program are that the average commute vehicle miles traveled (VMT) decreased from 17 miles one way in 1995 to 14 miles one way. The percentage of employees who drive alone decreased from over 91 percent in 1995 to less than 86 percent in 2003. The Employee Transportation Coordinator (ETC) estimates that the annual cost to Microsoft for its CTR program is $\$ 2$ million.

\section{Organizational Culture}

Issaquah is located in King County, Washington, near Seattle. Microsoft Corporation is an information services and software developer. This case study examined the original worksite that has been located for over 20 years on a suburban campus that employs 2,732 employees, 2,034 of which are affected by the Washington State Commute Trip Reduction Law. Since then, Microsoft has expanded to multiple worksites in the Puget Sound area. This worksite operates on a single daytime shift. The ETC said that the CTR program is seen by the organization as making good business sense as well as an opportunity to demonstrate corporate responsibility. Microsoft has been a member of the Greater Redmond TMA, the Bothell Transportation Partnership and an ETC network. Microsoft has worked directly with Metro to identify partnership opportunities in which Microsoft can fund augmented transit service for its employees. Microsoft has also served on several committees to examine bus service expansion and numerous transportation studies with state and local governments as well as lobbied for 


\section{Microsoft Corporation}

Issaquah, WA

interchange and transit improvements.

\section{External Characteristics}

Traffic congestion conditions are described by the ETC as an ' 8 ', on a scale of ' 1 ' to ' 10 ', ' 1 ' being free flow and ' 10 ' being gridlock. These conditions have remained constant over the past year. Shopping is available within $1 / 4$ mile of the site. The ETC said that the primary motivator for using alternative commute modes for the employees is time savings through the use of HOV lanes. A new bus route recently enabled another to switch modes. The ETC said the bus service is generally "okay" and good from Seattle. There are a couple of Sound Transit routes that offer regional express service and arrive every 12 minutes. All the other Metro routes are local and meander through neighborhoods and are coming from neighboring cities and are not as good. Those from adjacent cities will not take the bus because it takes twice as long. Transit service quality improves the farther away a commuter is traveling from.

\section{On-Site Amenities}

There is a transit center onsite. There is also a bike lane, sidewalks, bicycle and pedestrian paths, several cafeterias and banking onsite. Most employees stay onsite for lunch. There is covered and uncovered bicycle parking as well as lockers and shower facilities and a casual dress code.

\section{Employee Characteristics}

The employees are primarily a highly-skilled highly-paid professional work force representing a wide range of job classifications. The ETC observed that employees with families tend to live in neighboring suburbs that are closer to the Microsoft and tend to drive rather than take the slow local bus service. Alternatively, younger employees living closer to downtown Seattle will take the bus.

\section{Commute Trip Reduction Program}

The ETC runs a centralized transportation program called "Microsoft Commute", which provides a variety of services and maintains transportation facilities for all employees as well as contractors and vendors who work on site. There are a total of 2,147 parking spaces onsite that are owned by Microsoft, free to employees and monitored by security personnel. There are no reserved parking spaces for any tier of employees except for carpool and vanpool riders. The data suggest that the physical facilities of the campus, including parking supply, grew since 1999 to accommodate a growing number of employees, up from 445 in 1999 . Onsite parking was leased until 2002, after which 150 carpool and vanpool parking spaces were designated in 2004. 


\section{Microsoft Corporation}

Issaquah, WA

The ETC makes sure there are enough HOV parking spaces for all registered carpoolers and vanpoolers.

The ETC's activities have included distributing summaries of the CTR program, providing information to new employees, posting materials, conducting CTR events, publishing articles in the weekly MicroNews, and conducting internal web based ridematching and an email bulletin board public folder for ad-hoc ridematching. The folder gets 30-40 messages each day to take advantage of SR 520 HOV lanes. There are other email folders for bicyclists and transit riders. Microsoft provides a Flexpass for transit riders and $\$ 65$ per month per vanpooler or ferry rider. Vendors and contractors located on-site are not eligible for the subsidies. Microsoft also provides an on-call internal shuttle service that transports employees among Microsoft buildings and to nearby park and ride lots. The shuttle provides approximately 50,000 trips per month and has eliminated the need for employees to have their personal vehicles at hand for midday trips. Microsoft also provides a guaranteed ride home program.

All regular employees work on a flextime schedule per arrangement with their managers. Flexible work schedules are "in keeping with the corporate culture of the company. Employees often come to work late, leave work late or take time off in the middle of the day for personal needs." Typically, employees will arrive after 10 a.m. and work until 9 p.m. Less than two percent of employees are on a compressed work week. Telecommuting is allowed at the discretion of the manager as appropriate for the job description. The percentage of telecommuters in 1997 was over 32 percent. This percentage decreased to close to zero by 2001, then increased again to 23 percent in 2003. These fluctuations may have been influenced by interruptions due to facilities development and expansion. Telecommuting arrangements vary from one day to more than 5 days every two weeks.

The ETC's services are displayed at the reception desk, in the mail room and on the company web site. There are online resources, including a web site, an online employee handbook and an email help line that receives 20-25 enquiries each day. The ETC has an active worksite committee to assist him that includes trained receptionists at each building on site as well as additional part-time and administrative staff that provide the equivalent of at least one full time assistant. Each receptionist has a handbook and access to online resources.

\section{Employee Transportation Coordinator}

The ETC has been serving in this capacity since 2003 and formerly worked as an ETC at two other companies for 10 years. The ETC is the Transportation Manager. He has a separate office and works full time on CTR program duties. His ETC duties are explicitly written as part of his job description. The ETC has completed a training course and works full time on commute trip reduction activities. 
Organization Information (2004)

\section{Microsoft Corporation Issaquah, WA}

Website: www.microsoft.com

Primary Business:

Non-profit organization? Information

Total Employees:

No

Affected Employees:

2732

2034

Is the CTR program subject to collective bargaining? No

Does this worksite have multiple shifts? No

Shifts description:

$\mathrm{N} / \mathrm{A}$

CTR program contact:

David Lantry

King County Metro

400 Yesler Way, MS YES-TR-0650, Seattle, WA 98104

Phone: (206) 684-1139

Email: david.lantry@metrokc.gov

\section{Worksite Characteristics (2004)}

$\begin{array}{cccccc}\text { Bus stop(s) } & \text { Bike lane } & \text { Sidewalks } & \text { Restaurants } & \text { Shopping } & \text { Bank } \\ \text { Availability } & \text { Availability } & \text { Availability } & \text { Availability } & \text { Availability } & \text { Availability } \\ \text { Onsite } & \text { Onsite } & \text { Onsite } & \text { Onsite } & \text { Within 1/4 mile } & \text { Onsite }\end{array}$

\section{Program Narrative (1999)}

Microsoft operates a centralized transportation program called "Microsoft Commute" that is available at all Microsoft Puget Sound sites. Microsoft commute provides information and services on all types of all types of transportation and is responsible for managing the Microsoft Flex pass, carpool program, vanpool program, guaranteed ride home program, Microsoft shuttle, bicycle and pedestrian facilities and parking for all Microsoft sites in the Puget Sound area. The benefits offered by Microsoft Commute program are all available to not only affected Microsoft employees, but also to affected employees and contractors and vendors working at Microsoft sites. The centralized Microsoft commute program also provides: Online resources on commute alternatives (website, email help line, email aliases). Rideshare, Microsoft's web based ride matching and carpool registration program. Provides information and regular updates to building coordinators. Coordinates promotions, company wide and at particular sites. Creates Microsoft wide newspaper articles and electronic communications. Provides material for weekly new employment orientation meetings. Ongoing marketing campaigns and events. Coordination with local jurisdictions, WSDOT and transit providers on transportation issues. Full time staff focusing on commute and transportation issues. Microsoft shuttle services for all employees. Biweekly meetings with Metro on transit issues Takes part in the Greater Redmond TMA (current board chair). At each Microsoft building (not site, but building) there is an on-site representative who provides the primary initial point of direct contact for employees. Any employee seeking information on commuting issues can visit the reception desk in their building for information on where to get the access to key elements of the Commute program. Each reception desk has information on all elements of the commute program immediately available. Receptionists are trained on the commute program and how to access elements of it. They have a handbook and access to on-line resources. There is also a commute program brochure available at all desks. In addition, they are in constant email and phone contact with the centralized commute program.

General information: This is accomplished through a variety of on-line and paper means. Electronics means include website, direct email, e-mail aliases an online employee handbook, and Ride find- an online ride matching program. Paper distributions include articles and classified ads in the weekly MicroNews news letter, quarterly distribution of the Greater Redmond TMA newsletter, bus maps, timetables, ride match applications and bus passes. In addition, information about the "COMMUTE" program, website and e-mail alias are provided to new employees as a part of weekly new employee orientation session that takes places at Microsoft. Information 
provided through all of these means ranged from general commute information (including information about commute alternatives, Oil Smart, Bicycle to work Day, Rideshare Week, etc.) to specify information about Microsoft's Commuter program and incentives.

INFORMATION DISTRIBUTION: Commute email alias is the central e-mail alias where employees can inquire about anything related to commuting. Essentially, this is an email help available to all employees with commute related questions. This e-mail alias is monitored daily by transportation staff and an average $20-$ 25 messages a day are received and responded to. These enquires relate to transit, vanpooling, carpooling, parking, bicycling and walking. This email alias is publicized through the on-line employee hand book, weekly new employee orientation sessions, campus signage and in the MicroNews. Carpooling commuters email alias is for ad-hoc ride matching and longer time ride matching. People choose to include themselves on a email distribution list and receive daily requests from other Microsoft employees looking for rides or offering rides. Exchange public folders were used extensively to share information about commute alternatives. All public folders are accessible to every Microsoft employee who can read and post information to them. Pubic folders are essentially on-line bulletin boards where employees and commute program staff can exchange information about commuting Montlake is public folder for ad-hoc ride matching for commuters who live in Seattle. Employees use this folder to solicit/ offer rides to fellow Seattlites in order to take advantage of the SR- 520 HOV lanes. Traffic on this folder averages 30- 40 messages a day and rides are offered to a variety of Seattle neighborhoods including Montlake, Madison Park, Queen Anne, Wedgewood, Central district, and Capitol Hill. This folder is used by bus riders and is often used to transit information about Metro service changes. Msbike is a public folder for bicycle enthusiasts at Microsoft, but is used to exchange information about bicycle commuting. Microsoft hand book is an online web based resource provided to all Microsoft employees. This handbook includes extensive information about Microsoft commute program and various elements and benefits available to employees. New employee orientation sessions are conducted weekly. These sessions include a discussion of commute reduction program in the "Getting Started" introductory guide to resources and systems at Microsoft. This discussion identifies where employees can go to get more information on transportation resources. Commute web site is another online tool available to help employees get basic information about commute options available to them at Microsoft and the programs that the company offers encourage their use. Enhanced information may be provided at a latter date. Commute program brochure is distributed to all reception desks three times an year and is included in employee orientation packages for all new Microsoft employees. Bus schedule distribution takes place three times a year coordinated with the Metro service changes. Schedules are available at all reception desk and on the commute website.

PROGRAMS: Ride share in Microsoft's own map based ride matching software. The software is available to all Microsoft employees, contractors and vendors on the company intranet. An employee simply enter their address and commute schedule and the program returns a map that shows where potential carpool partners live near the employee's home. The program also allows employees to register in an intranet database to get a carpool parking pass. The program also provides ongoing conformation emails to carpool members and carpool owners and tracks when employees leave Microsoft or change worksites. Bicycle and pedestrian site amenities are provided at most Microsoft sites. These amenities include bicycle parking, clothes lockers and showers. There are also a number of bicycle and pedestrian paths serving the Microsoft main campus. Preferential carpool and vanpool parking is provided at all Microsoft worksites. The number of spaces provided at each building (on main campus) is based on the number of registered carpools at those buildings. At each building we provide enough HOV stalls to meet the demand of registered carpools and vanpools plus three additional spaces. Flex pass/ financial incentives are provided to transit riders and vanpoolers. A one year trial program of the Microsoft employees contractors and vendors. A \$21 per month subsidy is provided to employees purchasing community transit passes or bus ticket books. Customer bus service is provided by Microsoft at several sites. Microsoft is paying for additional trips on two Metro routes to better serve Microsoft employees. Additional trips to routes 263 and 242 are funded by Microsoft. Microsoft is currently working with Metro to identify other trips and routes where a partnership between Metro and Microsoft might make sense. Flexible work schedules are available to many Microsoft employees and are keeping with the corporate culture of the company. Employees often come into work late, leave work late or take time off in the middle of the day for personal needs. This policy is allowed throughout Microsoft and is worked out on an individual work group and manager basis. The exact level of usage of flexible start time by Microsoft employees is very difficult to estimate since work hours are not closely tracked or monitored for most employees. Microsoft shuttle provides on-call service form any Microsoft building to any other building. The shuttle regularly operates between 7:30a.m to 9:30p.m with extended hours for recruiting purposes two nights a week. Shuttle ride ship averages about 50,000 trips per month. The Microsoft shuttle removes need for employees to have a personal vehicle available midday for trips between Microsoft sites. This greatly encourages the use of alternatives to SOV. Microsoft shuttle also provides links between Microsoft sites and nearby Park and Ride lots. PRO club shuttle provides lunch time service between main campus, Redmond West and the PRO club. This shuttle operates 
in addition to the regular Microsoft shuttle between 11:00a.m and 2:20p.m. This removes the need for personal vehicles midday for these trips. Commute program administrator is a full time Microsoft staff position established in 1996 to focus on the commute and transportation needs of Microsoft employees. The staff in this position will be responsible fro the development, management and creation of Microsoft's employee commute program. This staff works with building representatives to provide the Microsoft Commute program and its services to all employees. Additional part-time and administrative staff provide at least one full addition FTE working on transportation and commute issues. Participation in regional projects and partnerships: Microsoft is an active regional partner working with other employers and public agencies in throughout the region. Greater Redmond transportation management Association: Microsoft is a founding and active member of Greater Redmond TMA. Two Microsoft representatives take part in TMA meetings. Bothell transportation Partnership: Microsoft is an ongoing member of the Bothell Transportation partnership. Metro Eastside sounding board: A Microsoft representative served on the Metro Eastside sounding board planning bus services changes for 1997 as a part of the Metro Six Year plan. We have been asked to take part in the new Eastside sounding board beginning in late 1998. Microsoft has also made information about proposed changes available to our employees through email, flyer distribution and through articles in our weekly newsletter. Bellevue Redmond Overlake transportation study: A Microsoft representative serves on the citizens advisory group for this study of transportation needs in the Bellevue- Redmond- Overlake areas. Ride find: Microsoft worked with the Washington state Dept. of Transportation offices of Urban Mobility to make its online ride matching program available to other employers in the region. Rider link: Microsoft served as a primary employer contact on the creation of the Ride link internet home page being created by Metro and the Overlake TMA. NE 40th street interchange: Microsoft has worked closely with the Washington state Dept. of Transportation, the city of Redmond of Bellevue to lobby for the creation of a new interchange on SR- 520 at NE 40th street. We have also been working with Metro to ensure that it is "transit friendly". Finally, Microsoft is providing significant financial support towards the development of this interchange. This interchange is a critical facet of responding to traffic issues in the Bellevue- Redmond- Overlake area. Dedication of transit center property: As a part of proposal to develop additional property in the Overlake area, Microsoft has agreed to dedicate a 10 acre property along SR- 520 at NE 40th street for use as a transit center. Consolidation of Metro service near most of the employment in the Overlake region is a key to make transit service more effective. Transit center development: Microsoft is working closely with the City of Redmond, the Regional transit authority and Metro on the planning and development of a transit center at SR- 520 and NE 40th street. Microsoft played a key role in lobbing to have the RTA schedule for the transit center moved up so that transit center could be complete when the interchange is complete.

\section{Worksite Parking and Parking Management Information}

\section{Parking management and monitoring (2004)}

Security monitors and enforces parking.

\begin{tabular}{|c|c|c|c|c|}
\hline \multicolumn{5}{|c|}{ Parking } \\
\hline Program & Total Num of & Onsite Parking & Offsite Parking & Leased Onsite \\
\hline Year & Employees & Spaces & Spaces & Parking Spaces \\
\hline 1999 & 445 & 887 & 0 & 887 \\
\hline 2000 & 519 & 887 & & 887 \\
\hline 2001 & 935 & 1543 & 0 & 1543 \\
\hline 2002 & 2170 & 2084 & & 0 \\
\hline 2004 & 2732 & 2147 & 0 & 0 \\
\hline Program & Leased Offsite & \multicolumn{2}{|c|}{ Leased Onsite Parking } & Leased Offsite Parking \\
\hline Year & Parking Spaces & \multicolumn{2}{|c|}{ Price (Space/Month) } & Price (Space/Month) \\
\hline 1999 & 0 & \multicolumn{2}{|c|}{ Included in lease } & \\
\hline 2000 & 0 & \multicolumn{2}{|c|}{ Included in lease } & \\
\hline 2001 & 0 & \multicolumn{2}{|c|}{ Included in lease } & \\
\hline 2002 & 0 & & & \\
\hline 2004 & 0 & & & \\
\hline
\end{tabular}




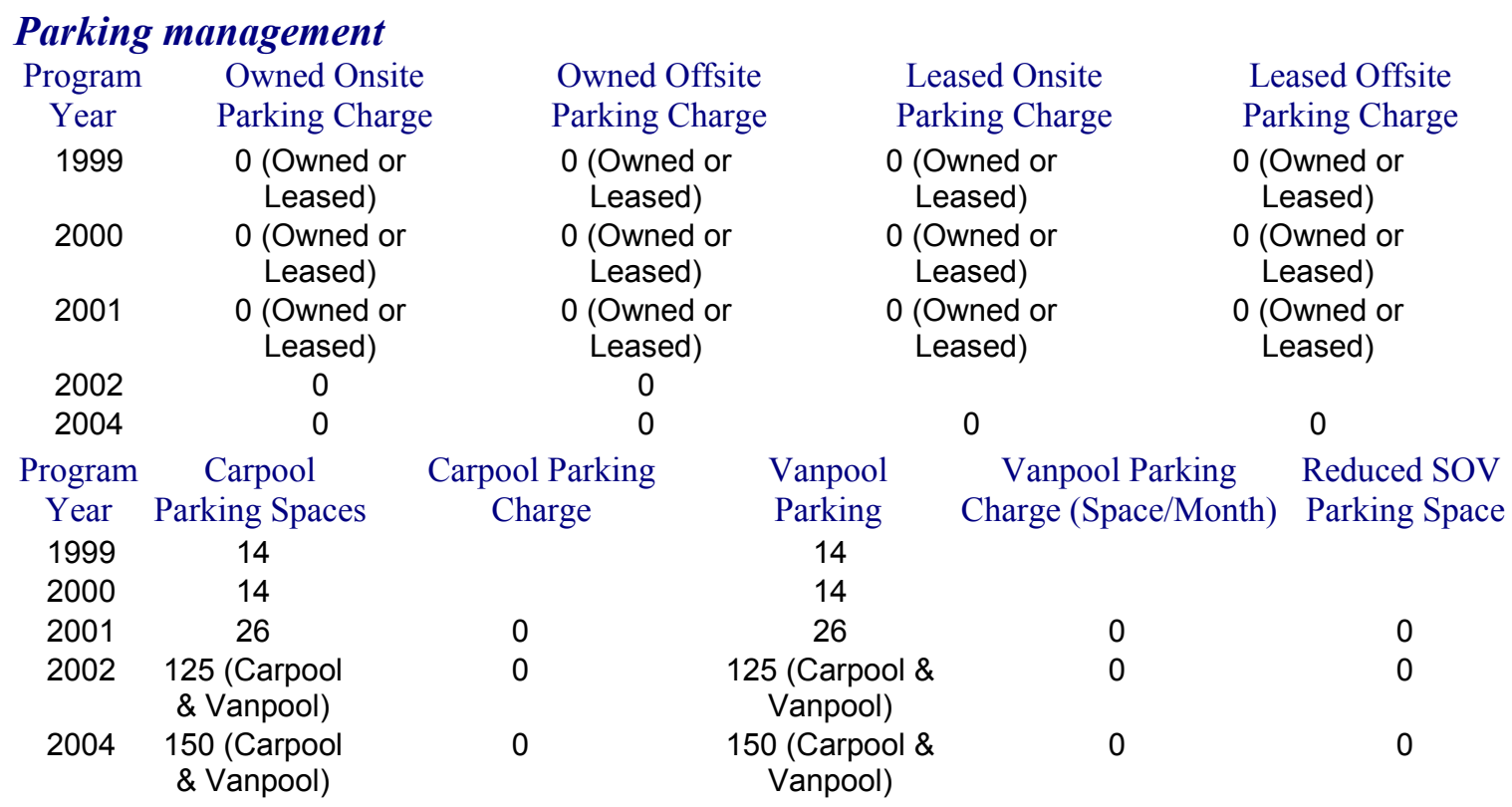

\section{Program Promotion}

\section{General (2004)}

Is the ETC's name, location and telephone number prominently displayed at this Yes

Displayed where? At Reception Desk, in Mail Room \& on company website.

Has the ETC completed a program developer/ETC training course? Yes

On average, how many hours per week does the ETC spend on CTR activities? 40

Does the ETC have an active worksite committee to assist with the CTR Yes

\section{Program promotion}

\begin{tabular}{|c|c|c|c|c|c|c|}
\hline $\begin{array}{l}\text { Program } \\
\text { Year }\end{array}$ & $\begin{array}{c}\text { Distribute } \\
\text { Summary of CTR }\end{array}$ & $\begin{array}{r}\mathrm{P} \\
\text { Inforn }\end{array}$ & $\begin{array}{l}\text { rovide CTR Pro } \\
\text { hation to New }\end{array}$ & ployees & $\begin{array}{c}\text { Post } \\
\text { Materials }\end{array}$ & $\begin{array}{c}\text { Give Managers } \\
\text { Presentation }\end{array}$ \\
\hline 1999 & Yes & & Yes & & & \\
\hline 2000 & Yes & & Yes & & Yes & No \\
\hline 2001 & Yes & & Yes & & Yes & Yes \\
\hline 2002 & Yes & & Yes & & Yes & Yes \\
\hline 2004 & Yes & & Yes & & Yes & No \\
\hline Program & Give & Conduct & Publish & Dist & bute & Distribute \\
\hline Year & Employees & CTR Events & CTR Articles & Informa & on with & Ridematch \\
\hline 1999 & & Yes & Yes & $\mathrm{N}$ & & Yes \\
\hline 2000 & Yes & Yes & Yes & $\mathrm{N}$ & & Yes \\
\hline 2001 & Yes & Yes & Yes & $\mathrm{N}$ & & Yes \\
\hline 2002 & Yes & Yes & Yes & $\mathrm{N}$ & & Yes \\
\hline 2004 & No & Yes & Yes & $\mathrm{N}$ & & Yes \\
\hline
\end{tabular}

\section{Site Amenities}

$\begin{array}{cccccc}\begin{array}{c}\text { Program } \\ \text { Year }\end{array} & \begin{array}{c}\text { Covered } \\ \text { Bicycle Spaces }\end{array} & \begin{array}{c}\text { Uncovered } \\ \text { Bicycle Spaces }\end{array} & \begin{array}{c}\text { Clothes } \\ \text { Lockers }\end{array} & \text { Showers } & \begin{array}{c}\text { Non-SOV On-site } \\ \text { Loading/Unloading }\end{array} \\ 1999 & \text { Yes } & \text { Yes } & \text { Yes } & \text { Yes } & \\ 2000 & \text { Yes } & \text { Yes } & \text { Yes } & \text { Yes } & \text { Yes } \\ 2001 & \text { Yes } & \text { Yes } & \text { Yes } & \text { Yes } & \text { Yes } \\ 2002 & \text { Yes } & \text { Yes } & \text { Yes } & \text { Yes } & \text { Yes } \\ 2004 & \text { Yes } & \text { Yes } & \text { Yes } & \text { Yes } & \text { No }\end{array}$




\section{Financial Subsidies, Incentives or Allowances}

\begin{tabular}{|c|c|c|c|c|}
\hline $\begin{array}{l}\text { Program } \\
\text { Year }\end{array}$ & $\begin{array}{l}\text { Transit Subsidy } \\
\text { (Employee/Month) }\end{array}$ & $\begin{array}{l}\text { Vanpool Subsidy } \\
\text { (Employee/Month) }\end{array}$ & $\begin{array}{l}\text { Carpool Subsidy } \\
\text { (Employee/Month) }\end{array}$ & $\begin{array}{l}\text { Walking Subsidy } \\
\text { (Employee/Month) }\end{array}$ \\
\hline 1999 & $100 \%$ FlexPass/Metro & $\$ 57.50$ (FlexPass) & 0 & 0 \\
\hline 2000 & & $\$ 57.5$ & 0 & 0 \\
\hline 2001 & $\$ 63$ & $\$ 65$ & 0 & 0 \\
\hline 2002 & & $\$ 65$ & & \\
\hline 2004 & & $\$ 65$ & 0 & 0 \\
\hline $\begin{array}{l}\text { Program } \\
\text { Year }\end{array}$ & $\begin{array}{c}\text { Ferry Subsidy } \\
\text { (Employee/Month) }\end{array}$ & $\begin{array}{l}\text { Bicycling Subsidy } \\
\text { (Employee/Month }\end{array}$ & $\begin{array}{c}\text { Other Stipend } \\
\text { (Employee/Month) }\end{array}$ & \\
\hline 1999 & 0 & 0 & & \\
\hline 2000 & 0 & 0 & & \\
\hline 2001 & 0 & 0 & 0 & \\
\hline 2002 & 0 & & 0 & \\
\hline 2004 & $\$ 65$ & & 0 & \\
\hline
\end{tabular}

\section{Fleet Vehicles and Special Programs}

\section{Employer provided vehicles availability}

$\begin{array}{cccccc}\begin{array}{c}\text { Program } \\ \text { Year }\end{array} & \begin{array}{c}\text { FV Guaranteed } \\ \text { Ride Home }\end{array} & \text { FV Vanpool } & \begin{array}{c}\text { FV } \\ \text { Carpool }\end{array} & \begin{array}{c}\text { FV Work- } \\ \text { Related Trips }\end{array} & \begin{array}{c}\text { FV Non-Work } \\ \text { Related Errands }\end{array} \\ 1999 & \text { No } & \text { No } & \text { No } & \text { No } & \text { No } \\ 2000 & \text { No } & \text { No } & \text { No } & \text { No } & \text { No } \\ 2001 & \text { No } & \text { No } & \text { No } & \text { No } & \text { No } \\ 2002 & \text { No } & \text { No } & \text { No } & \text { No } & \text { No } \\ 2004 & \text { No } & \text { No } & \text { No } & \text { No } & \text { No }\end{array}$

\section{Other services availability}

$\begin{array}{cccc}\text { Program } & \text { Employer-Provided } & \text { Guaranteed Ride Home } & \text { Internal Match } \\ \text { Year } & \text { Shuttle } & \text { Program } & \text { Program } \\ 1999 & \text { Yes } & \text { Yes } & \\ 2000 & \text { Yes } & \text { Yes } & \\ 2001 & \text { Yes } & \text { Yes } & \\ 2002 & \text { Yes } & \text { Yes } & \text { Yes } \\ 2004 & \text { Yes } & \text { Yes } & \text { Yes }\end{array}$

\section{Mode Split and Vehicle Miles Traveled}

\begin{tabular}{|c|c|c|c|c|c|c|c|}
\hline Program & \multicolumn{2}{|c|}{ Num of Surveys } & \multicolumn{2}{|c|}{ Total Reported } & Driving & \multirow[t]{2}{*}{ Carpooling } & \multirow[t]{2}{*}{ Vanpooling } \\
\hline Year & Distribute & Num of & Commuting & Days & Alone & & \\
\hline 1995 & 236 & & 839 & & $91.6567 \%$ & $7.3897 \%$ & $0.0000 \%$ \\
\hline 1997 & 405 & & 1188 & & $89.6465 \%$ & $9.4276 \%$ & $0.0000 \%$ \\
\hline 1999 & 473 & & 1665 & & $88.8288 \%$ & $9.7297 \%$ & $0.3003 \%$ \\
\hline 2001 & 607 & & 2049 & & $86.4812 \%$ & $8.9312 \%$ & $0.1952 \%$ \\
\hline 2003 & 697 & & 2052 & & $85.3801 \%$ & $12.1345 \%$ & $0.4873 \%$ \\
\hline Program & Public & Bicycling & Walking & Othe & & hicle Miles & \\
\hline Year & Transit & & & & & Traveled & \\
\hline 1995 & $0.0000 \%$ & $0.5959 \%$ & $0.0000 \%$ & 0.357 & & 17.29 & \\
\hline 1997 & $0.8418 \%$ & $0.0842 \%$ & $0.0000 \%$ & 0.000 & & 17.19 & \\
\hline 1999 & $1.0210 \%$ & $0.0000 \%$ & $0.0000 \%$ & 0.120 & & 17.09 & \\
\hline 2001 & $2.7330 \%$ & $0.0976 \%$ & $0.0488 \%$ & 1.512 & & 15.63 & \\
\hline 2003 & $1.3645 \%$ & $0.0487 \%$ & $0.1949 \%$ & 0.389 & & 13.76 & \\
\hline
\end{tabular}




\section{Compressed Work Week, Flex Time and Teleworking}

Policy (2001)

Flex Time

Teleworking

All regular employees work on a flextime schedule per arrangement with their managers

Telecommuting is allowed at the discretion of managers as appropiate for the job description

\section{Percentage of employees on Compressed Work}

\begin{tabular}{ccccc}
$\begin{array}{c}\text { Program } \\
\text { Year }\end{array}$ & $\begin{array}{c}\text { Num of Surveys } \\
\text { Distributed (Affected }\end{array}$ & $\begin{array}{c}\text { Total Surveys } \\
\text { Reported }\end{array}$ & $\begin{array}{c}\text { Percentage of Employees } \\
\text { On 5 Days/Week }\end{array}$ & $\begin{array}{c}\text { Percentage of Employees } \\
\text { On 3 Days/Week }\end{array}$ \\
1995 & 236 & 175 & $94.8571 \%$ & $0.0000 \%$ \\
1997 & 405 & 237 & $92.8270 \%$ & $0.4219 \%$ \\
1999 & 473 & 34 & $58.8235 \%$ & $0.0000 \%$ \\
2001 & 607 & 416 & $97.3558 \%$ & $0.0000 \%$ \\
2003 & 697 & 429 & $97.6690 \%$ & $0.0000 \%$ \\
Program & Percentage of Employees & Percentage of Employees & Percentage of Employees \\
Year & On 4 Days/Week & On 7 Days/Two Weeks & On 9 Days/Two Weeks \\
1995 & $0.0000 \%$ & \multicolumn{2}{c}{$0.0000 \%$} & $0.5714 \%$ \\
1997 & $0.0000 \%$ & \multicolumn{2}{c}{$0.0000 \%$} & $0.0000 \%$ \\
1999 & $0.0000 \%$ & $0.0000 \%$ & $0.0000 \%$ \\
2001 & $0.2404 \%$ & $0.0000 \%$ & $0.2404 \%$ \\
2003 & $1.8648 \%$ & $0.2331 \%$ & $0.2331 \%$
\end{tabular}

\section{Percentage of employees on Telecommuting}

\begin{tabular}{|c|c|c|c|c|c|}
\hline $\begin{array}{l}\text { Program } \\
\text { Year }\end{array}$ & \multicolumn{2}{|c|}{$\begin{array}{l}\text { Num of Surveys Distributed } \\
\text { (Num of Affected Employees) }\end{array}$} & $\begin{array}{l}\text { Total Surveys } \\
\text { Reported }\end{array}$ & $\begin{array}{l}\text { Total Percentage } \\
\text { of Telecommuters }\end{array}$ & $\begin{array}{l}1 \text { Days every } \\
\text { Two Weeks }\end{array}$ \\
\hline 1995 & \multicolumn{2}{|c|}{236} & & & \\
\hline 1997 & \multicolumn{2}{|c|}{405} & 239 & $32.2176 \%$ & $7.9498 \%$ \\
\hline 1999 & \multicolumn{2}{|c|}{473} & 334 & $8.6826 \%$ & $3.8922 \%$ \\
\hline 2001 & \multicolumn{2}{|c|}{607} & 356 & $0.2809 \%$ & $0.0000 \%$ \\
\hline 2003 & \multicolumn{2}{|c|}{697} & 463 & $23.9741 \%$ & $13.6069 \%$ \\
\hline Program & 2 Days every & 3 Days & 4 Days every & 5 Days every & More than 5 \\
\hline $\begin{array}{l}\text { Year } \\
1995\end{array}$ & Two Weeks & every Two & Two Weeks & Two Weeks & Days every Two \\
\hline 1997 & $22.5941 \%$ & $1.2552 \%$ & $0.4184 \%$ & $0.0000 \%$ & $0.0000 \%$ \\
\hline 1999 & $2.0958 \%$ & $0.8982 \%$ & $0.5988 \%$ & $0.5988 \%$ & $0.5988 \%$ \\
\hline 2001 & $0.0000 \%$ & $0.0000 \%$ & $0.0000 \%$ & $0.0000 \%$ & $0.2809 \%$ \\
\hline 2003 & $6.4795 \%$ & $1.2959 \%$ & $1.5119 \%$ & $0.2160 \%$ & $0.8639 \%$ \\
\hline
\end{tabular}




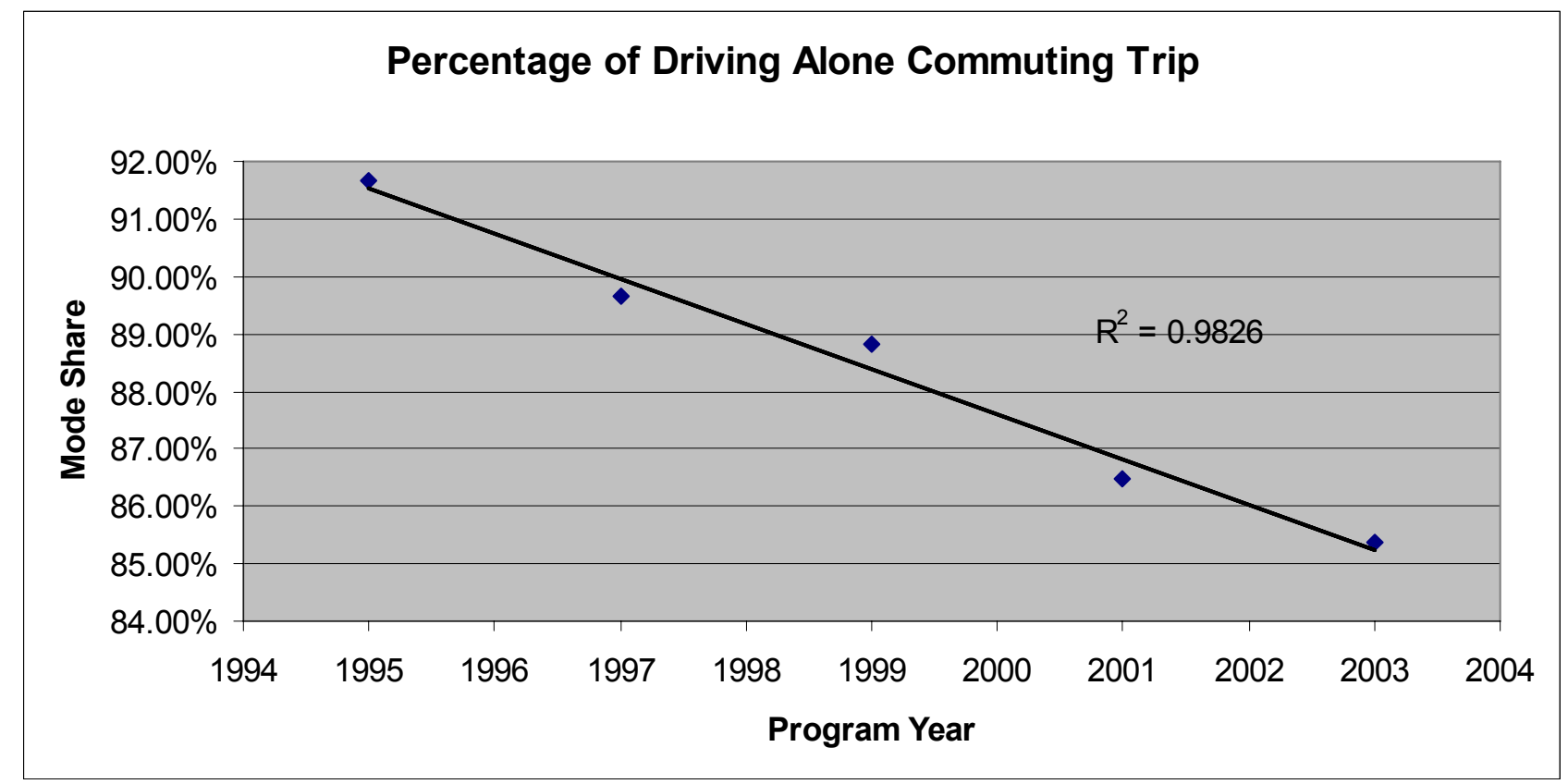

Figure 11: Percentage of Drive-Alone Commute Trips - Microsoft

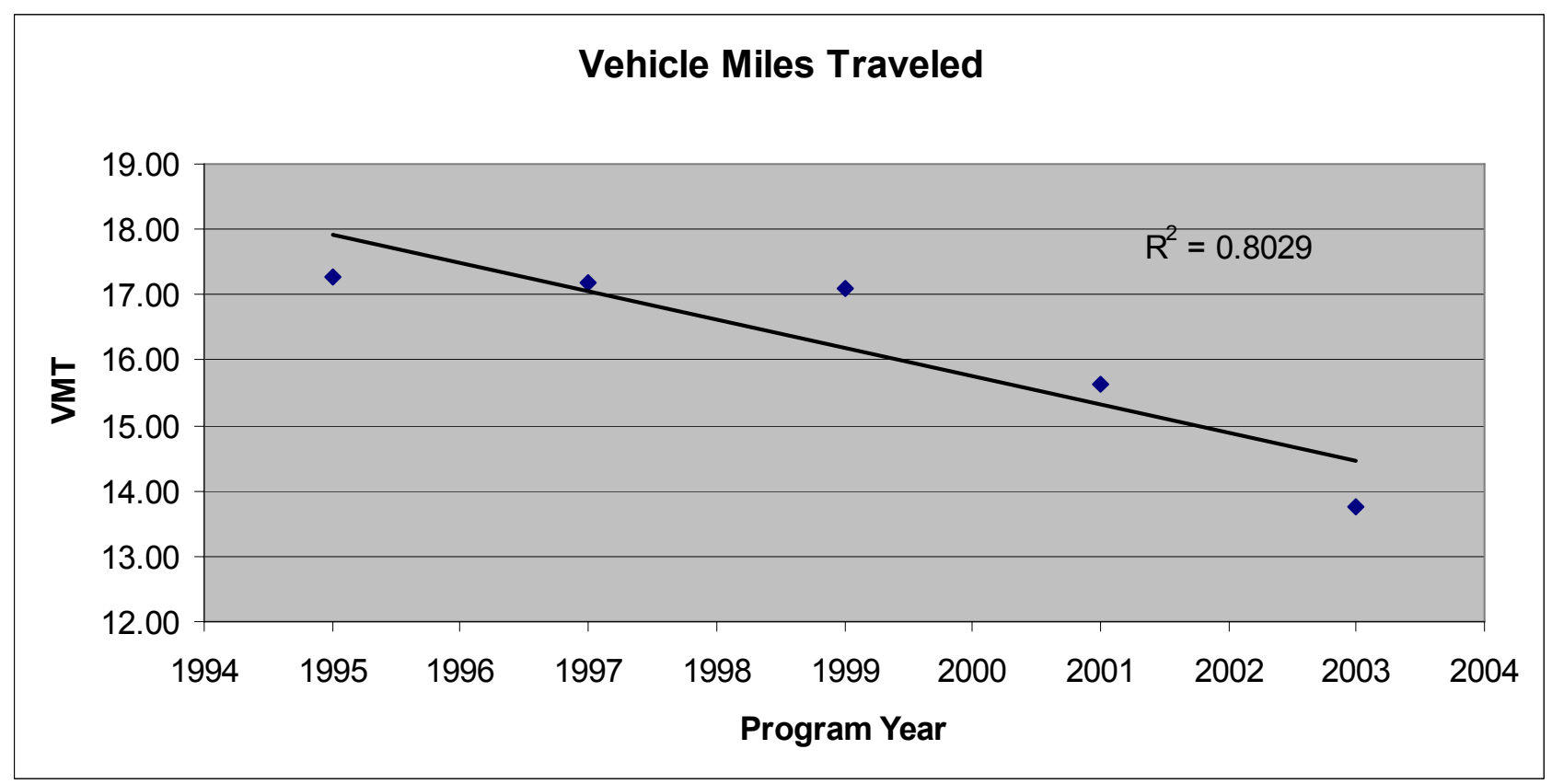

Figure 12: VMT - Microsoft 


\section{Pine Lodge Women's Correctional Facility}

Medical Lake, WA

\section{Keys to Success}

Pine Lodge is a minimum security women's correctional facility located in a rural setting approximately 20 minutes outside of Spokane, Washington. As a correctional facility, Pine Lodge had a number of significant barriers to overcome in the process of developing a successful commute trip reduction (CTR) program. Pine Lodge is located far from a commercial center and high quality transit and has many employees that are reluctant to give out the kind of information needed by a regional ridematching system. Being a 24 hour institution, many of its employees work a large variety of shifts and throughout the night, making transit use difficult. Despite these obstacles, Pine Lodge has over 20 percent of their employees carpooling to work and 42 of the 120 employees are participating in the program by using some kind of alternative mode, primarily carpooling. The employer transportation coordinator (ETC) credits upper management support, the rise in gas prices, and the regional ETC network for the success of their program. Anyone who gets a chance to talk to her about the CTR program will also discover that her passion and enthusiasm is also due credit.

\section{CTR Programs Elements}

- Internal ridematching system

- Preferential parking

- Quarterly prize incentives

- Bicycle parking

- Showers and lockers

\section{Results and Costs}

Between 1993 and 2003, Washington State DOT data indicates that the carpooling mode share at Pine Lodge increased from 15.7 percent to 20.6 percent as the drive alone mode share dropped from 81.7 percent to 75.1 percent. In that same time frame, the correctional facility's average one way vehicle miles traveled (VMT) per employee has decreased from 18.8 VMT to 14.3 VMT. In October 2006, 42 employees out of 120 were participating in their CTR program by using an alternative mode.

\section{External Factors}

Access to high-quality transit is often viewed as critical to developing an effective work trip reduction program. However, according to the ETC, the local transit agency is able to serve only a small number of employees well due to a combination of the agency's service hours and the nature of their business. The majority of employees at the correctional facility are custody 


\section{Pine Lodge Women's Correctional Facility}

\section{Medical Lake, WA}

officers (prison guards) who have a variety of shifts and changing schedules to maintain a 24 hour operation. As a result, taking the bus is not an option for the custody officers. Another factor that can make an ETC's job more difficult is an abundance of free parking. However, Pine Lodge provides free parking with lots large enough to accommodate all of the employees. Traffic congestion also is not something that would push an employee to use an alternative mode to get to work. So despite the availability of free parking, congestion free commuting, and low transit accessibility, the CTR program continues to be successful.

One external factor that is, in part, responsible for the success of the Pine Lodge CTR program is the assistance received from the Spokane County CTR Office. The ETC credits the Spokane County ETC network luncheons as the source for "good ideas to get more people to carpool, like different kinds of incentives." With her limited budget, she relies on learning innovative, lowcost strategies from the CTR office and other ETCs. She believes that the most important activity of an ETC is:

Being able to answer questions for staff when they have questions regarding their needs, and being informed enough to help them out.

For the ETC, the network luncheons serve as a means to share knowledge and learn from others on how to be an effective ETC. The ETC network luncheons also serve as a point of distribution for regional marketing campaigns, which helps to keep the cost of maintaining an employerbased CTR program lower.

Another more recent external factor that has contributed Pine Lodge's decrease in employees driving alone is the price of gas. With the increased price of gas in the last couple years, the ETC has seen an increased demand for ridesharing:

Not only are people that were carpooling, carpooling more, but also people that never carpooled are joining in because of the price of gas.

As a result of the impact of high gas prices on carpooling demand, the ETC has been granted five additional preferential parking spots for the CTR program "and if they fill up quickly, they are going to put five more up."

\section{Internal Factors}

Upper management support of the CTR program, as exhibited in the expansion of preferential parking, is viewed "extremely important" by the ETC. Pine Lodge's new Superintendent has prior experience with CTR programs and has not only given the ETC " $100 \%$ support," but put her at ease in her role as ETC:

He just barely started working for us, and within his second or third week here, he and I had a meeting. I was very nervous actually, but he put me at ease and he gave me what I wanted...And when he told me that he helped set up transport when he worked at Coyote Ridge, it made my day, because I knew I would have his support here. 


\section{Pine Lodge Women's Correctional Facility}

\section{Medical Lake, WA}

For matters of the CTR program, she reports directly to the Superintendent. This arrangement enables her to go right to the top when she needs assistance and receive instant feedback.

One internal factor that significantly shapes Pine Lodge's CTR program is related to the nature of the corrections business. For security reasons, employees of correctional facilities value their privacy. The majority of employees are custody officers who do not want their personal information, such as addresses, publicly available. Therefore, there is a strong reluctance to use RideMatch, the regional ridesharing program. To overcome this obstacle, Pine Lodge has developed an internal ridematching system for employees that want to carpool. In thinking about the organization culture of the facility, she believes that employees, especially the custodial officers, also feel more comfortable riding with their co-workers rather than people who work outside of the correctional facility due to societal perceptions and the nature of their job.

To run the internal ridematching system, the ETC does not use a computer program to organize a database but instead relies own skills. She does, however, use an internet-based commute calendar program, mycommute.org, to track alternative mode use by employees and randomly select winners of quarterly $\$ 35$ gift cards. At Pine Lodge, the gift cards are the only financial incentive offered for using an alternative mode. They do not offer any subsidies due to financial constraints. Based on her conversations with employees, the ETC believes that most employees carpool or ride the bus for financial reasons. However, she also believes that "it is also because they enjoy the company too."

\section{Employee Transportation Coordinator}

The final factor in the success of Pine Lodge's CTR program is the ETC herself. She is passionate and enthusiastic about her job as ETC and "gets a good feeling knowing that [she is] getting people involved". To get people involved in the program, she thinks it takes a combination of a positive attitude and good communication with co-workers. She also believes that it is important for ETCs to set a good example and use an alternative themselves:

I think it is important to do it yourself, and be involved in carpooling or bus riding. I have found that when we have had ETCs in the past that don't do either of those... I don't think the program was as successful... you have to walk the talk.

Being the ETC is very rewarding to her but she did not volunteer for the position. It was "handed to her" but she says that she had no problem taking it, "because it is something I highly believe in." She estimates that approximately five to ten percent of her time is spent administering the CTR program, although she wishes she had more time and additional staff to better organize and promote the program. Despite having a successful program already, she is eager to improve it and, as a result, improve the quality of life for her co-workers. 
Organization Information (2004)

\title{
Det of Corrections - Pine Lodge Women's Correctional Facility
} Medical Lake, WA

\author{
Website: \\ Primary Business: \\ Non-profit organization? \\ Total Employees: $\quad 114$ \\ Affected Employees: 114 \\ Is the CTR program subject to collective bargaining? Yes \\ Does this worksite have multiple shifts? Yes \\ Shifts description: \\ CTR program contact: \\ Aurora Crooks \\ TDM Manager, Spokane County CTR Office \\ 1026 W Broadway Ave., Spokane, WA 99260 \\ Phone: 509-477-7540 \\ Email: acrooks@spokanecounty.org
}

www.doc1.wa.gov

Other

Yes

Days, swing and graveyard (different day schedules for support, officers, and other facility staff)

\section{Worksite Characteristics (2004)}

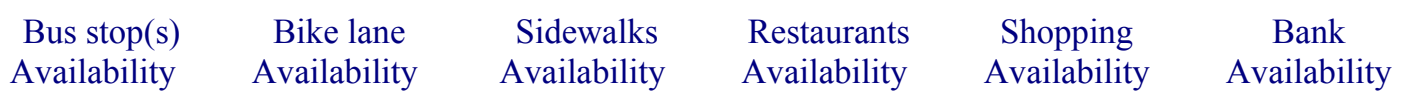

Within $1 / 4$ mile Within $1 / 4$ mile Onsite Not available Not available Not available

\section{Program Narrative (2000)}

Pine Lodge Pre-Release's Commute Trip Reduction Program is alive and well. We continue to see a slight increase in our number of carpooling staff. The numbers of staff who participate in the program commuting by city transit fluctuates throughout the year. We would hope to see an increase in rider participation during the winter months. Promotions and transfers out the PLPR also affect the numbers in participants. This year we have lost a few of our long time carpool participants as well as faithful bus riders. Pine Lodge is a 24-hour facility with a large portion of staff working swing and graveyard shifts. Public transportation is not an option for these staff members. A number of custody staff has put together carpools. When schedules allow, there is an average of six carpools used by custody staff. Kitchen staff does not have the same flexibility to use alternative modes, due to the varied shifts and limited staffing.

\section{Worksite Parking and Parking Management Information}

\section{Parking management and monitoring (2004)}

A committee has submitted a parking lot plan to management, but due to construction projects, and a future parking lot pavement project, it has not been implemented. It is projected sometime in April of 2004.

$\begin{array}{ccccc}\begin{array}{c}\text { Parking } \\ \text { Program }\end{array} & \begin{array}{c}\text { Total Num of } \\ \text { Employees }\end{array} & \begin{array}{c}\text { Onsite Parking } \\ \text { Spaces }\end{array} & \begin{array}{c}\text { Offsite Parking } \\ \text { Spaces }\end{array} & \begin{array}{c}\text { Leased Onsite } \\ \text { Parking Spaces }\end{array} \\ 1999 & 130 & 100 & 0 & 0 \\ 2000 & 140 & 100 & & 0 \\ 2001 & 140 & 100 & 0 & 0 \\ 2002 & 124 & 100 & & 0 \\ 2003 & 124 & 100 & 0 & 0 \\ 2004 & 114 & 100 & 0 & 0\end{array}$




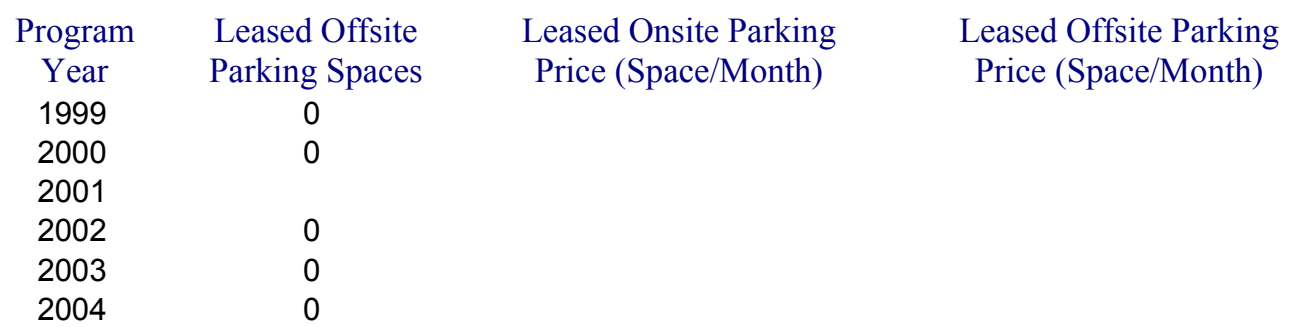

\section{Parking management}

\begin{tabular}{|c|c|c|c|c|c|c|}
\hline Program & Owned Onsite & Owned Offsi & & Leased Onsite & & ased Offsite \\
\hline Year & Parking Charge & Parking Char & & Parking Charge & Par & king Charge \\
\hline 1999 & $\begin{array}{c}0 \text { (Owned or } \\
\text { Leased) }\end{array}$ & $\begin{array}{l}0 \text { (Owned or } \\
\text { Leased) }\end{array}$ & & $\begin{array}{l}\text { (Owned or } \\
\text { Leased) }\end{array}$ & 0 (O & $\begin{array}{l}\text { wned or } \\
\text { eased) }\end{array}$ \\
\hline 2000 & $\begin{array}{c}0 \text { (Owned or } \\
\text { Leased) }\end{array}$ & $\begin{array}{c}0 \text { (Owned or } \\
\text { Leased) }\end{array}$ & & $\begin{array}{l}\text { (Owned or } \\
\text { Leased) }\end{array}$ & 0 (O & $\begin{array}{l}\text { wned or } \\
\text { eased) }\end{array}$ \\
\hline 2001 & $\begin{array}{c}0 \text { (Owned or } \\
\text { Leased) }\end{array}$ & $\begin{array}{c}0 \text { (Owned or } \\
\text { Leased) }\end{array}$ & & $\begin{array}{l}\text { (Owned or } \\
\text { Leased) }\end{array}$ & 0 (O & $\begin{array}{l}\text { wned or } \\
\text { eased) }\end{array}$ \\
\hline 2002 & 0 & 0 & & & & \\
\hline 2003 & 0 & 0 & & 0 & & 0 \\
\hline 2004 & 0 & 0 & & 0 & & 0 \\
\hline Program & Carpool & Carpool Parking & Vanpool & Vanpool & & Reduced SOV \\
\hline Year & Parking Spaces & Charge & Parking & Charge (Spe & onth) & Parking Space \\
\hline 1999 & 4 & 0 & 0 & & & 0 \\
\hline 2000 & 4 & & & & & \\
\hline 2001 & 4 & 0 & 0 & 0 & & 0 \\
\hline 2002 & $\begin{array}{c}3 \text { (Carpool \& } \\
\text { Vanpool) }\end{array}$ & & $\begin{array}{c}3 \text { (Carpool } 8 \\
\text { Vanpool) }\end{array}$ & & & \\
\hline 2003 & $\begin{array}{c}3 \text { (Carpool \& } \\
\text { Vanpool) }\end{array}$ & 0 & $\begin{array}{c}3 \text { (Carpool } 8 \\
\text { Vanpool) }\end{array}$ & $\&$ & & 0 \\
\hline 2004 & $\begin{array}{c}3 \text { (Carpool \& } \\
\text { Vanpool) }\end{array}$ & 0 & $\begin{array}{c}3 \text { (Carpool } 8 \\
\text { Vanpool) }\end{array}$ & \& & & 0 \\
\hline
\end{tabular}

\section{Program Promotion}

\section{General (2004)}

Is the ETC's name, location and telephone number prominently displayed at this Yes

Displayed where? CTR Board in Admin Lobby and Walker Hall

Has the ETC completed a program developer/ETC training course?

On average, how many hours per week does the ETC spend on CTR activities? 3

Does the ETC have an active worksite committee to assist with the CTR No

\section{Program promotion}

$\begin{array}{ccccc}\begin{array}{c}\text { Program } \\ \text { Year }\end{array} & \begin{array}{c}\text { Distribute } \\ \text { Summary of CTR }\end{array} & \begin{array}{c}\text { Provide CTR Program } \\ \text { Information to New Employees }\end{array} & \begin{array}{c}\text { Post } \\ \text { Materials }\end{array} & \begin{array}{c}\text { Give Managers } \\ \text { Presentation }\end{array} \\ 1999 & \text { Yes } & \text { Yes } & \text { Yes } & \text { Yes } \\ 2000 & \text { Yes } & \text { Yes } & \text { Yes } & \text { Yes } \\ 2001 & \text { Yes } & \text { Yes } & \text { Yes } & \text { Yes } \\ 2002 & \text { Yes } & \text { Yes } & \text { Yes } & \text { No } \\ 2003 & \text { Yes } & \text { Yes } & \text { Yes } & \text { No } \\ 2004 & \text { Yes } & \text { Yes } & \text { Yes } & \text { No }\end{array}$




$\begin{array}{cccccc}\begin{array}{c}\text { Program } \\ \text { Year }\end{array} & \begin{array}{c}\text { Give } \\ \text { Employees }\end{array} & \begin{array}{c}\text { Conduct } \\ \text { CTR Events } \\ \text { Yes }\end{array} & \begin{array}{c}\text { Publish } \\ \text { CTR Articles }\end{array} & \begin{array}{c}\text { Distribute } \\ \text { Information with }\end{array} & \begin{array}{c}\text { Distribute } \\ \text { Ridematch }\end{array} \\ 2009 & \text { Yes } & \text { Yes } & \text { No } & \text { Yes } & \text { No } \\ 2001 & \text { Yes } & \text { Yes } & \text { Yes } & \text { Yes } & \text { Yes } \\ 2002 & \text { No } & \text { Yes } & \text { Yes } & \text { Yes } & \text { Yes } \\ 2003 & \text { No } & \text { Yes } & \text { Yes } & \text { Yes } & \text { Yes } \\ 2004 & \text { No } & \text { Yes } & \text { Yes } & \text { Yes } & \text { No }\end{array}$

\section{Site Amenities}

$\begin{array}{cccccc}\begin{array}{c}\text { Program } \\ \text { Year }\end{array} & \begin{array}{c}\text { Covered } \\ \text { Bicycle Spaces }\end{array} & \begin{array}{c}\text { Uncovered } \\ \text { Bicycle Spaces }\end{array} & \begin{array}{c}\text { Clothes } \\ \text { Lockers }\end{array} & \text { Showers } & \begin{array}{c}\text { Non-SOV On-site } \\ \text { Loading/Unloading }\end{array} \\ 1999 & \text { No } & \text { Yes } & \text { Yes } & \text { Yes } & \text { Yes } \\ 2000 & \text { No } & \text { Yes } & \text { Yes } & \text { Yes } & \text { Yes } \\ 2001 & \text { No } & \text { Yes } & \text { Yes } & \text { Yes } & \text { Yes } \\ 2002 & \text { No } & \text { Yes } & \text { Yes } & \text { Yes } & \text { No } \\ 2003 & \text { No } & \text { Yes } & \text { Yes } & \text { Yes } & \text { No } \\ 2004 & \text { Yes } & \text { Yes } & \text { Yes } & \text { Yes } & \end{array}$

\section{Financial Subsidies, Incentives or Allowances}

$\begin{array}{ccccc}\begin{array}{c}\text { Program } \\ \text { Year }\end{array} & \begin{array}{c}\text { Transit Subsidy } \\ \text { (Employee/Month) }\end{array} & \begin{array}{c}\text { Vanpool Subsidy } \\ \text { (Employee/Month) }\end{array} & \begin{array}{c}\text { Carpool Subsidy } \\ \text { (Employee/Month) }\end{array} & \begin{array}{c}\text { Walking Subsidy } \\ \text { (Employee/Month) }\end{array} \\ 1999 & 0 & 0 & 0 & 0 \\ 2000 & \$ 8 & 0 & \$ 18 & 0 \\ 2001 & 0 & 0 & 0 & 0 \\ 2002 & \$ 25 & 0 & \$ 25 & 0 \\ 2003 & 0 & 0 & 0 & 0 \\ 2004 & 0 & 0 & 0 & 0 \\ \text { Program } & \text { Ferry Subsidy } & \text { Bicycling Subsidy } & \text { Other Stipend } & \\ \text { Year } & \text { (Employee/Month) } & \text { (Employee/Month } & \text { (Employee/Month) } & \\ 1999 & 0 & 0 & 0 & \\ 2000 & 0 & \$ 2 & 0 & \\ 2001 & 0 & 0 & 0 & \\ 2002 & 0 & 0 & 0 & \\ 2003 & 0 & 0 & 0 & \\ 2004 & 0 & 0 & 0 & \end{array}$

\section{Fleet Vehicles and Special Programs}

\section{Employer provided vehicles availability}

$\begin{array}{cccccc}\begin{array}{c}\text { Program } \\ \text { Year }\end{array} & \begin{array}{c}\text { FV Guaranteed } \\ \text { Ride Home }\end{array} & \text { FV Vanpool } & \begin{array}{c}\text { FV } \\ \text { Carpool }\end{array} & \begin{array}{c}\text { FV Work- } \\ \text { Related Trips }\end{array} & \begin{array}{c}\text { FV Non-Work } \\ \text { Related Errands }\end{array} \\ 1999 & \text { No } & \text { No } & \text { No } & \text { Yes } & \text { No } \\ 2000 & \text { No } & \text { No } & \text { No } & \text { No } & \text { No } \\ 2001 & \text { No } & \text { No } & \text { No } & \text { No } & \text { No } \\ 2002 & \text { No } & \text { No } & \text { No } & \text { Yes } & \text { No } \\ 2003 & \text { No } & \text { No } & \text { No } & \text { Yes } & \text { No } \\ 2004 & \text { No } & \text { No } & \text { No } & \text { Yes } & \text { No }\end{array}$




\section{Other services availability}

$\begin{array}{cccc}\text { Program } & \text { Employer-Provided } & \text { Guaranteed Ride Home } & \text { Internal Match } \\ \text { Year } & \text { Shuttle } & \text { Program } & \text { Program } \\ 1999 & \text { No } & \text { Yes } & \\ 2000 & \text { No } & \text { Yes } & \\ 2001 & \text { No } & \text { Yes } & \text { No } \\ 2002 & \text { No } & \text { Yes } & \text { No } \\ 2003 & \text { No } & \text { Yes } & \text { No } \\ 2004 & \text { No } & \text { Yes } & \end{array}$

\section{Mode Split and Vehicle Miles Traveled}

\begin{tabular}{|c|c|c|c|c|c|c|c|}
\hline $\begin{array}{l}\text { Program } \\
\text { Year }\end{array}$ & \multicolumn{2}{|c|}{$\begin{array}{l}\text { Num of Surveys } \\
\text { Distributed (Num of }\end{array}$} & \multicolumn{2}{|c|}{$\begin{array}{l}\text { Total Reported } \\
\text { Commuting Days }\end{array}$} & $\begin{array}{l}\text { Driving } \\
\text { Alone }\end{array}$ & Carpooling & Vanpooling \\
\hline 1993 & 10 & & 203 & & $81.7734 \%$ & $15.7635 \%$ & $0.0000 \%$ \\
\hline 1995 & 125 & & 346 & & $74.8555 \%$ & $14.4509 \%$ & $0.0000 \%$ \\
\hline 1997 & 122 & & $35 \varepsilon$ & & $80.1676 \%$ & $16.2011 \%$ & $0.0000 \%$ \\
\hline 1999 & 132 & & $37 \varepsilon$ & & $79.3651 \%$ & $15.0794 \%$ & $0.0000 \%$ \\
\hline 2001 & 116 & & 356 & & $81.1798 \%$ & $16.2921 \%$ & $0.0000 \%$ \\
\hline 2003 & 132 & & $20 \varsigma$ & & $75.1196 \%$ & $20.5742 \%$ & $0.0000 \%$ \\
\hline Program & Public & Bicycling & Walking & Other & & hicle Miles & \\
\hline Year & Transit & & & & & Traveled & \\
\hline 1993 & $2.4631 \%$ & $0.0000 \%$ & $0.0000 \%$ & 0.0000 & & 18.84 & \\
\hline 1995 & $10.4046 \%$ & $0.2890 \%$ & $0.0000 \%$ & 0.0000 & & 16.04 & \\
\hline 1997 & $3.3520 \%$ & $0.2793 \%$ & $0.0000 \%$ & 0.0000 & & 15.24 & \\
\hline 1999 & $3.9683 \%$ & $0.0000 \%$ & $0.0000 \%$ & 1.5873 & & 15.06 & \\
\hline 2001 & $2.5281 \%$ & $0.0000 \%$ & $0.0000 \%$ & 0.0000 & & 14.82 & \\
\hline 2003 & $2.3923 \%$ & $0.0000 \%$ & $0.0000 \%$ & 1.9139 & & 14.27 & \\
\hline
\end{tabular}

\section{Compressed Work Week, Flex Time and Teleworking}

\section{Policy (2001)}

Flex Time

Appointing authorities who have approved the use of flex time schedules will ensure staff coverage to meet the established normal business hours. Managers are encouraged to consider alternate or flex time schedules, where appropriate, to alleviate the need for overtime, gain flexibility in enhancing services to the organixation, assist with meeting commute trip reduction goals, and/or provide desirable schedules for employees. DOC policy 825.010

Teleworking

\section{Percentage of employees on Compressed Work}

$\begin{array}{ccccc}\begin{array}{c}\text { Program } \\ \text { Year }\end{array} & \begin{array}{c}\text { Num of Surveys } \\ \text { Distributed (Affected }\end{array} & \begin{array}{c}\text { Total Surveys } \\ \text { Reported }\end{array} & \begin{array}{c}\text { Percentage of Employees } \\ \text { On 5 Days/Week }\end{array} & \begin{array}{c}\text { Percentage of Employees } \\ \text { On 3 Days/Week }\end{array} \\ 1993 & 100 & 42 & 97.6190 \% & 0.0000 \% \\ 1995 & 125 & 76 & 90.7895 \% & 0.0000 \% \\ 1997 & 122 & 77 & 96.1039 \% & 0.0000 \% \\ 1999 & 132 & 82 & 90.2439 \% & 0.0000 \% \\ 2001 & 116 & 77 & 89.6104 \% & 0.0000 \% \\ 2003 & 134 & 49 & 91.8367 \% & 0.0000 \%\end{array}$




$\begin{array}{cccc}\begin{array}{c}\text { Program } \\ \text { Year }\end{array} & \begin{array}{c}\text { Percentage of Employees } \\ \text { On 4 Days/Week }\end{array} & \begin{array}{c}\text { Percentage of Employees } \\ \text { On 7 Days/Two Weeks }\end{array} & \begin{array}{c}\text { Percentage of Employees } \\ \text { On 9 Days/Two Weeks }\end{array} \\ 1993 & 2.3810 \% & 0.0000 \% & 0.0000 \% \\ 1995 & 9.2105 \% & 0.0000 \% & 0.0000 \% \\ 1997 & 3.8961 \% & 0.0000 \% & 0.0000 \% \\ 1999 & 8.5366 \% & 0.0000 \% & 0.0000 \% \\ 2001 & 7.7922 \% & 0.0000 \% & 0.0000 \% \\ 2003 & 6.1224 \% & 0.0000 \% & 0.0000 \%\end{array}$

Percentage of employees on Telecommuting

\begin{tabular}{|c|c|c|c|c|c|}
\hline $\begin{array}{l}\text { Program } \\
\text { Year }\end{array}$ & \multicolumn{2}{|c|}{$\begin{array}{l}\text { Num of Surveys Distributed } \\
\text { (Num of Affected Employees) }\end{array}$} & $\begin{array}{l}\text { Total Surveys } \\
\text { Reported }\end{array}$ & $\begin{array}{l}\text { Total Percentage } \\
\text { of Telecommuters }\end{array}$ & $\begin{array}{l}1 \text { Days every } \\
\text { Two Weeks }\end{array}$ \\
\hline 1993 & \multicolumn{2}{|c|}{100} & 42 & $0.0000 \%$ & $0.0000 \%$ \\
\hline 1995 & \multicolumn{2}{|c|}{125} & 77 & $0.0000 \%$ & $0.0000 \%$ \\
\hline 1997 & \multicolumn{2}{|c|}{122} & 77 & $0.0000 \%$ & $0.0000 \%$ \\
\hline 1999 & \multicolumn{2}{|c|}{132} & 83 & $2.4096 \%$ & $0.0000 \%$ \\
\hline 2001 & \multicolumn{2}{|c|}{116} & 78 & $0.0000 \%$ & $0.0000 \%$ \\
\hline 2003 & \multicolumn{2}{|c|}{134} & 48 & $0.0000 \%$ & $0.0000 \%$ \\
\hline Program & 2 Days every & 3 Days & 4 Days every & 5 Days every & More than 5 \\
\hline Year & Two Weeks & every Two & Two Weeks & Two Weeks & Days every Two \\
\hline 1993 & $0.0000 \%$ & $0.0000 \%$ & $0.0000 \%$ & $0.0000 \%$ & $0.0000 \%$ \\
\hline 1995 & $0.0000 \%$ & $0.0000 \%$ & $0.0000 \%$ & $0.0000 \%$ & $0.0000 \%$ \\
\hline 1997 & $0.0000 \%$ & $0.0000 \%$ & $0.0000 \%$ & $0.0000 \%$ & $0.0000 \%$ \\
\hline 1999 & $1.2048 \%$ & $1.2048 \%$ & $0.0000 \%$ & $0.0000 \%$ & $0.0000 \%$ \\
\hline 2001 & $0.0000 \%$ & $0.0000 \%$ & $0.0000 \%$ & $0.0000 \%$ & $0.0000 \%$ \\
\hline 2003 & $0.0000 \%$ & $0.0000 \%$ & $0.0000 \%$ & $0.0000 \%$ & $0.0000 \%$ \\
\hline
\end{tabular}




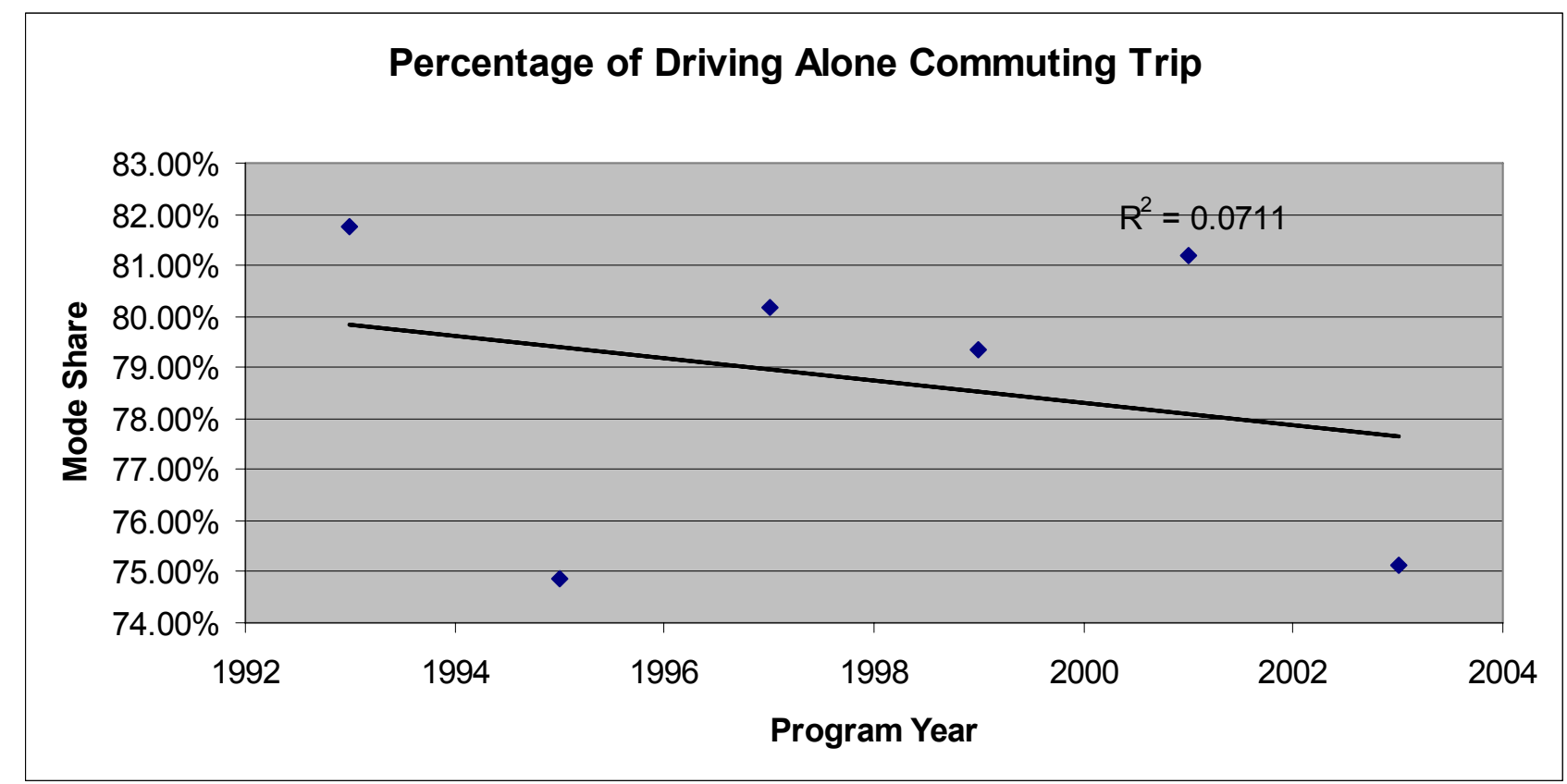

Figure 13: Percentage of Drive-Alone Commute Trips - Pine Lodge Women's Correctional Facility

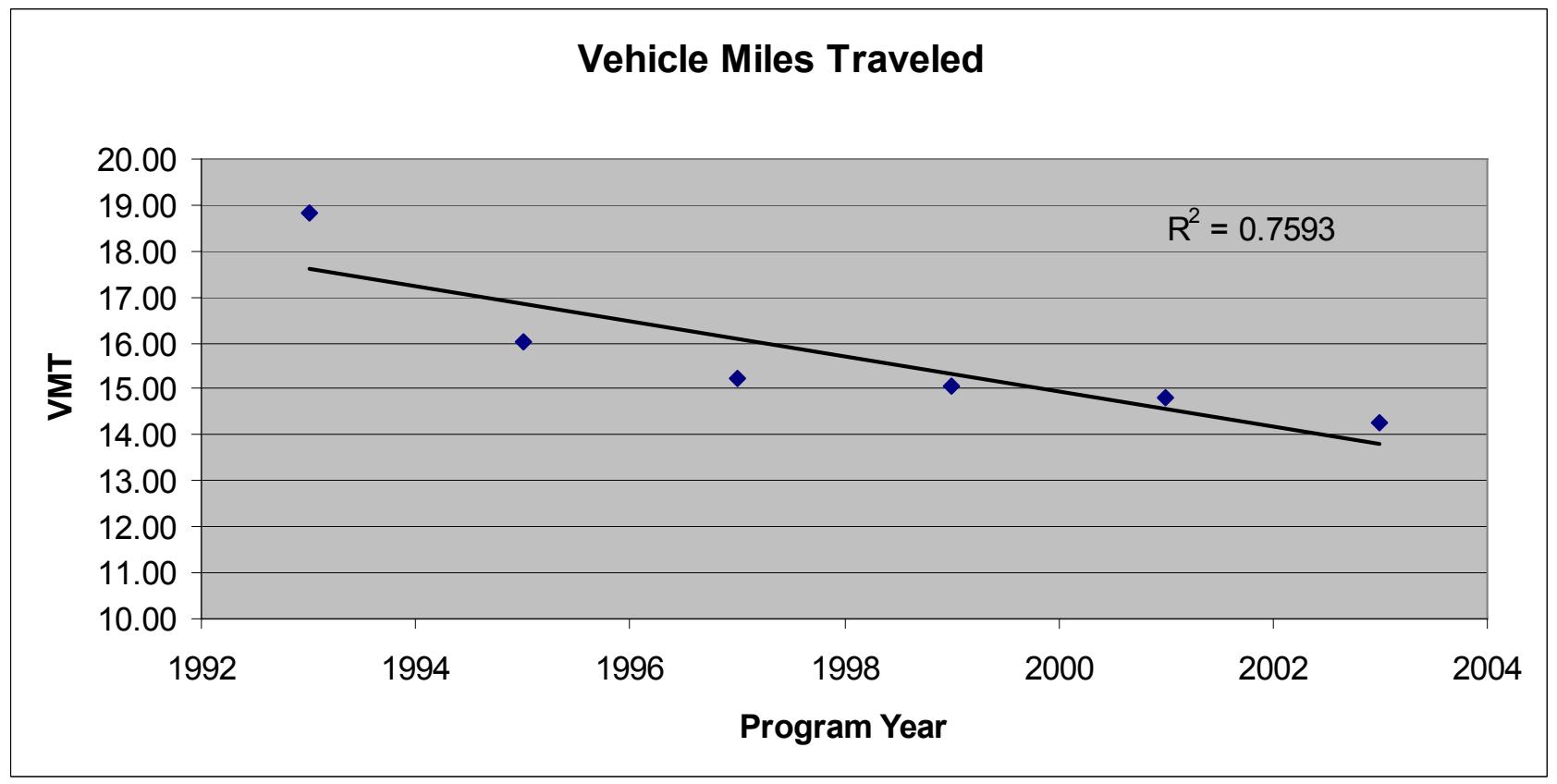

Figure 14: VMT - Pine Lodge Women's Correctional Facility 


\section{St. Joseph's Hospital}

Bellingham, WA

\section{Keys to Success}

St. Joseph's Hospital is located in the central business district of Bellingham, Washington. The hospital is one of the largest employers in the city, employing approximately 2,200 workers. In response to Washington State's commute trip reduction (CTR) law, St. Joseph's created their Smart Commuters Opting for Other Transport or SCOOT program to administer and promote their commute reduction program. The success of the program is based on both internal and external factors. Externally, the program has been impacted by transit service limitations, parking availability and higher gas prices. Outside support from the regional CTR program housed at the Whatcom Council of Governments (COG) is also credited with contributing to the program's success through the provision of time-saving pre-packaged promotional campaigns and their Employee Transportation Coordinator (ETC) network luncheons. Without a doubt, the success of the program is also due to the significant financial commitment by the hospital and the support of executive staff. While the financial decision was in part a reaction to parking availability and the state's trip reduction law, the corporate culture of the hospital and the knowledge and enthusiasm of the ETC also have influenced their CTR program. Due to their efforts, St. Joseph's Hospital has earned the distinction as a Best Workplaces for Commuters employer.

\section{Results and Cost}

Between 1997 and 2003, St. Joseph's Hospital decreased their drive-alone mode share from 95.7 percent to 83.7 percent. That decrease was primarily due to an increase in carpooling from 0.5 percent in 1997 to 9.9 percent in 2003. As a result of these changes, the hospital's average one way vehicle miles traveled (VMT) per employee has decreased from 8.87 VMT to 7.81 VMT. Recently, higher gas prices have resulted in further success. According to the ETC, over 230 employees participate in the SCOOT program and receive credits.

The annual budget of their SCOOT program is approximately $\$ 60,000$, with the bulk going toward subsidies for alternative mode use.

\section{CTR Program Elements}

- Free bus pass

- Subsidies for carpooling, walking, bicycling, telecommuting, and compressed work week

- Monthly prizes

- Internal ridematching system

- Bicycle parking and secure lockers

- Showers and Lockers 


\section{St. Joseph's Hospital}

Bellingham, WA

\section{External Factors}

Located in the central business district of Bellingham, the hospital has good access to transit with a stop right in front of the main building. However, being a 24 hour hospital, the transit agency's schedule cannot fit the needs of many of its employees. According to the ETC:

The transit service is good location wise, meaning there is a bus stop right in front of the main hospital, but it is not really sufficient as far as the schedule and what it offers as far as hours to our 24/7 facility with multiple shifts. For our day shift employees, which make up our largest population, they definitely use transit and it works great for them. Unfortunately, Bellingham is just not a large enough town for the transit agency to be able to provide those real expanded hours, like you would find in a large city, such as in Seattle, where the transit runs early morning and late evening times.

Despite these issues, hospital employees can receive a free bus pass ( $\$ 20$ value) and approximately 2 percent of employees use transit to commute to work.

Traffic congestion is not one of the external factors that motivates employees to participate in the program. However, the limited availability of parking, especially during the day shifts, has played a key role in shaping the SCOOT program at St. Joseph's because of their location in a central business district. According to the ETC, the unavailability of parking is the primary reason for the existence of the subsidies and the upper management's support of the SCOOT program. When faced with limited parking, the hospital decided that it made more sense to subsidize alternative commute modes than invest their money in the construction of a parking garage.

Another external factor that contributes to the success of their SCOOT program is the outside assistance the hospital receives from Susan Horst, the regional employer outreach coordinator of the Whatcom COG.

Susan Horst is dynamite and really supportive of all of the ETCs. We meet once a month and go over new programs. Someone from the transit agency usually tells us about new routes and new programs they are offering, and we just talk about things that are working and things that are not working.

The ETC network run by WCOG also serves as a point of distribution for regional marketing campaigns. Like most ETCs, the administration of the CTR programs is a small part of their total job responsibilities, so being able to use these "pre-packaged marketing campaigns" saves them time and effort. As the ETC stated, "I have a full time job without managing this commute program...I love it, it's one of my favorite things about my job and WCOG really makes it easy for us." Her involvement in the ETC network has also led to increased cooperation with other employers in the central business district.

The increased price of gas is seen as another significant factor contributing to the increased participation in the SCOOT program. Not only have employees that were already in the program increased their frequency of using alternative modes, but the ETC has seen many more employees switching from driving alone to using an alternative as the price of gas increased. 


\section{St. Joseph's Hospital}

Bellingham, WA

\section{Internal Factors}

There are many internal factors that have contributed to the success of the hospital's SCOOT program. Clearly, one of those factors is the range of incentives offered to its employees. The hospital offers free bus passes as well as subsidies or "credits" for carpooling, walking, bicycling, and telecommuting. The credit is $\$ 1.92$ a day, which comes out to be about $\$ 1.50$ after taxes. To be eligible for the credit, employees must use the alternative two days per week. The ETC uses an internally-designed online commute calendar to track employee travel behavior. Employees go to the calendar throughout the month to record their trips and then, after the month has closed, the credits are added to their paycheck. The online commute calendar is also used to select recipients of monthly incentive drawings. The winner receives a $\$ 25 \mathrm{gift}$ certificate and is highlighted in the hospital newsletter to receive recognition for their commute choices.

For ridematching, the hospital has its own online program "where employees can post ads" and they provide a link to the regional ridematching program on their website. Most employees use the internal one because of their shift schedules and because the employees are "more comfortable carpooling with people they know from work," according to the ETC.

The ETC estimates that the hospital spends approximately $\$ 60,000$ per year running the program, providing bus passes, the alternative commute credits and other incentives. As previously mentioned, the financial decision to provide those benefits was influenced by the hospital's parking situation and the state's trip reduction law. At this level of financial commitment, the executive staff not only supports the program but they actively encourage employees to participate in the program.

While a key financial decision in response to the trip reduction law served as the impetus for the program, the ETC believes that the hospital's corporate culture has also played a role in the program's success. As she explains, the value placed on community relations and promoting healthy lifestyles encourages the executive staff to support the program:

I think the success of the SCOOT Program is related a lot to the hospital's culture. I think in any program you need top down support and I think that our executive staff has been very supportive, in part because of the financial side, and in part because of the community and wanting to be doing the best they can as a good member of our community; being that we are one of the largest employers in our town. And also supporting a healthy lifestyle for our employees is valued since we are a hospital.

The hospital's culture not only influences the executive staff, but other employees as well. As a result, several employees, particularly the bicycle commuters, are identified as "cheerleaders" of the program and contribute to the success of the program. As the ETC explains, the key part these employees play is promoting the program by word of mouth:

There are some other cheerleaders that help... nine times out of ten the employee who comes to me did not think of [joining the program] on their own, someone talked to them about it. 


\section{St. Joseph's Hospital}

\section{Bellingham, WA}

As is often the case, those employees that are vocal and involved in promoting the program also receive additional benefits; about two years ago the hospital added secure bicycle lockers to the array of benefits they offer their employees.

\section{Employee Transportation Coordinator}

Another reason for the SCOOT Program's success is the enthusiasm and knowledge of the ETC, who has served in this capacity at St. Joseph's Hospital for the last two years. Before joining the hospital, she worked at Sound Transit of Seattle and was able to bring knowledge from that experience to her role as ETC for the hospital. She was also an environmental studies major in college and sees the bigger picture behind the trip reduction program as a step towards making a difference in the community and improving the city's quality of life by getting people out of their cars. What she loves most about her job as ETC is "giving people solutions and options" as she thinks "some people forget that they have other options or think they are stuck, as far as their transportation options."

When asked about the advice she would give to a new ETC she replied:

Two things I think of, one would be communication, you can't say it enough to your employees what the program is about, how it works and what they can get out of it... and then secondly incentives. Not every place will necessarily be able to provide an incentive credit like we do, but even if they just do a quarterly drawing or something like a free lunch it would help because I think people are motivated by incentives.

She communicates to her co-workers in many ways. The SCOOT program is included in the orientation for new hires. With every regional promotional campaign, she sends out a global email to alert employees and distributes or displays the collateral material provided by COG. The employee hospital newsletter is also used to highlight the program and monthly winners of the gift certificates. She also maintains a kiosk with promotional brochures at the main campus and the south campus.

She estimates she spends about 8 hours a month directly working on the program. When not working on the program, the ETC is a Benefits Specialist in the Human Resources department. While the performance of the program is not part of her annual evaluation, she is expected to adequately administer the SCOOT program. 


\title{
Organization Information (2006)
}

\section{St. Joseph Hospital}

Bellingham, WA

Website:

www.peacehealth.org

Primary Business:

Non-profit organization?

Health Care

Total Employees:

Yes

2188

Affected Employees:

573 each for both campuses

Is the CTR program subject to collective bargaining? No

Does this worksite have multiple shifts?

Yes

Shifts description:

A number of departments at Main and South Campuses are staffed 24/7

\section{CTR program contact:}

\author{
Susan Horst \\ Employer Outreach Coordinator, Whatcom COG \\ 314 East Champion Street, Bellingham, WA 98225-450 \\ Phone: (360) 676-6974 \\ Email: susan@wcog.org
}

\section{Worksite Characteristics (2005)}

$\begin{array}{cccccc}\text { Bus stop(s) } & \text { Bike lane } & \text { Sidewalks } & \text { Restaurants } & \text { Shopping } & \text { Bank } \\ \text { Availability } & \text { Availability } & \text { Availability } & \text { Availability } & \text { Availability } & \text { Availability } \\ \text { Onsite } & \text { Not available } & \text { Onsite } & \text { Onsite } & \text { Within 1/4 mile Within 1/4 mile }\end{array}$

\section{Program Narrative (2001)}

1. Reimburse employees $\$ 0.75$ a day if they walk, bicycle or carpool at least two days a week. Or they have the option of a free bus pass ( $\$ 15.00$ value).

2. Guaranteed Ride Home - Registered smart commuters are guaranteed a free taxi ride home in the event of illness, emergency or unexpected overtime.

3. Reserved rideshare parking and ridematching assistance - We've set aside parking spaces for employees carpooling and vanpooling.

4. Showers and lockers are available for commuters.

5. Covered and locked bicycle racks are located outside our emergency room.

6. Smart Commuter Discounts are available.

7. We provide monthly calendars to employees to keep track of the days they participate.

8. We draw a name each month from the Smart Commute participants and present a $\$ 25.00$ gift certificate for the Bellis Fair Mall for the monthly winner.

9. Participate in the Bike Challenge and presented a \$250.00 DVD player to the winning name. 


\section{Worksite Parking and Parking Management Information \\ Parking management and monitoring (2005)}

The parking lot has been equipped with cameras as well as patrolled by the security dept.

\section{Parking}

$\begin{array}{ccccc}\begin{array}{c}\text { Program } \\ \text { Year }\end{array} & \begin{array}{c}\text { Total Num of } \\ \text { Employees }\end{array} & \begin{array}{c}\text { Onsite Parking } \\ \text { Spaces }\end{array} & \begin{array}{c}\text { Offsite Parking } \\ \text { Spaces }\end{array} & \begin{array}{c}\text { Leased Onsite } \\ \text { Parking Spaces }\end{array} \\ 1999 & 235 & 250 & 0 & 0 \\ 2000 & 260 & 250 & 0 & 0 \\ 2001 & 249 & 250 & 0 & 0 \\ 2002 & 309 & 250 & 0 & 0 \\ 2003 & 309 & 250 & 0 & 0 \\ 2004 & 311 & 250 & \text { Leased Offsite Parking } \\ 2005 & 288 & \text { Leased Onsite Parking } & \text { Price (Space/Month) } \\ \text { Program } & \text { Leased Offsite } & \text { Price (Space/Month) } & \\ \text { Year } & \text { Parking Spaces } & & & \\ 1999 & 0 & & & \\ 2000 & 0 & & & \\ 2001 & 0 & & & \\ 2002 & 0 & & & \\ 2003 & 0 & & & \\ 2004 & 0 & & & \\ 2005 & 0 & & & \end{array}$

Parking management

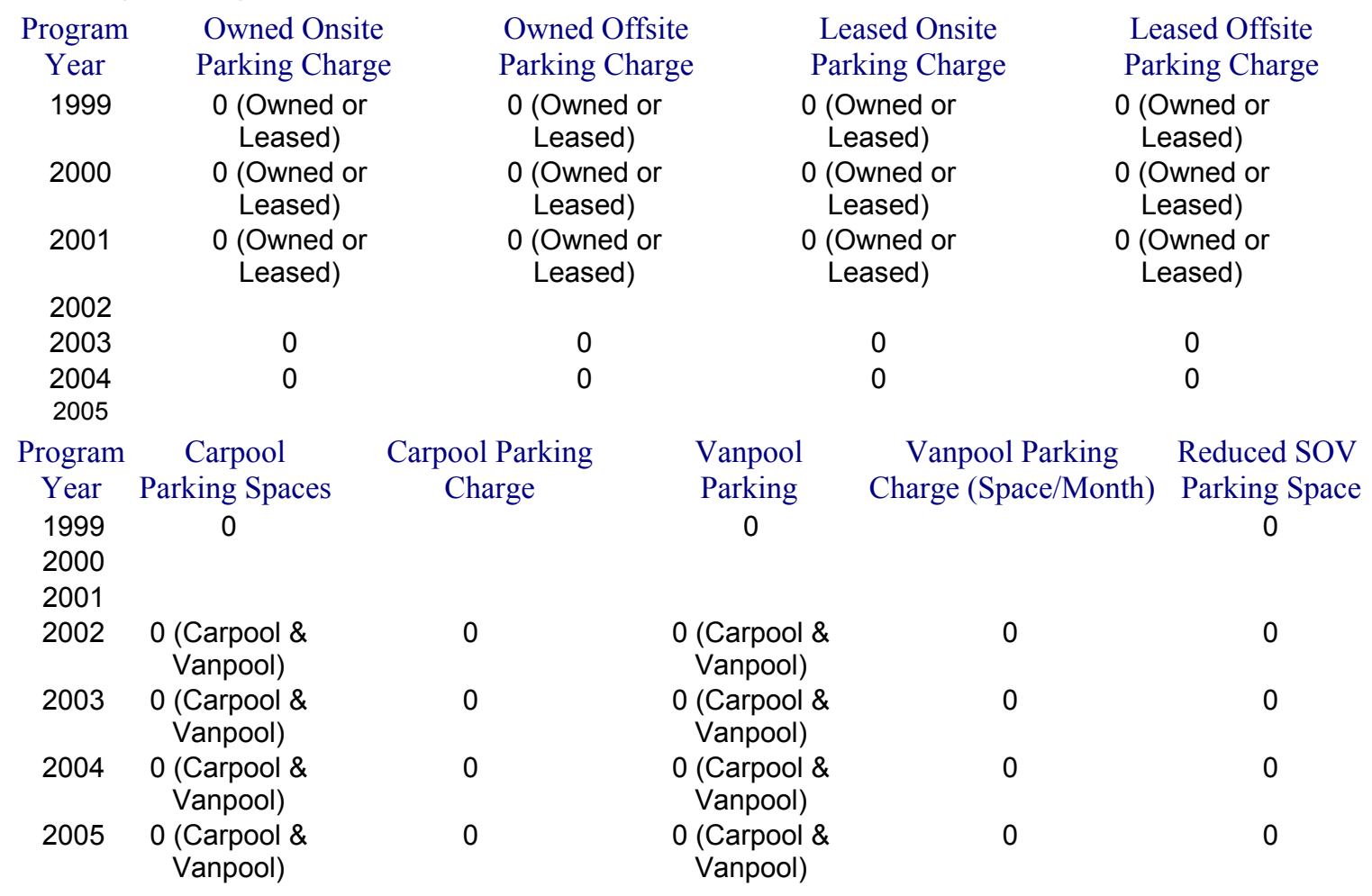




\section{Program Promotion}

\section{General (2005)}

Is the ETC's name, location and telephone number prominently displayed at this

Has the ETC completed a program developer/ETC training course?
On average, how many hours per week does the ETC spend on CTR

Yes

3

Does the ETC have an active worksite committee to assist with the CTR

No

\section{Program promotion}

\begin{tabular}{|c|c|c|c|c|c|c|}
\hline $\begin{array}{l}\text { Program } \\
\text { Year }\end{array}$ & Distribute & $\begin{array}{r}\mathrm{P} \\
\text { Inforr }\end{array}$ & \multicolumn{2}{|c|}{ Provide CTR Program } & $\begin{array}{c}\text { Post } \\
\text { Materials }\end{array}$ & $\begin{array}{c}\text { Give Managers } \\
\text { Presentation }\end{array}$ \\
\hline 1999 & Yes & & Yes & & Yes & Yes \\
\hline 2000 & Yes & & Yes & & Yes & Yes \\
\hline 2001 & Yes & & Yes & & Yes & Yes \\
\hline 2002 & Yes & & Yes & & Yes & No \\
\hline 2003 & Yes & & Yes & & Yes & No \\
\hline 2004 & Yes & & Yes & & Yes & No \\
\hline 2005 & Yes & & Yes & & Yes & No \\
\hline Program & Give & Conduct & Publish & Dist & bute & Distribute \\
\hline Year & Employees & CTR Events & CTR Articles & Informa & on with & Ridematch \\
\hline 1999 & Yes & Yes & Yes & $\mathrm{Ye}$ & & No \\
\hline 2000 & No & Yes & Yes & $\mathrm{Ye}$ & & Yes \\
\hline 2001 & Yes & Yes & No & $\mathrm{Ye}$ & & Yes \\
\hline 2002 & Yes & Yes & Yes & No & & Yes \\
\hline 2003 & Yes & Yes & Yes & $\mathrm{Nc}$ & & Yes \\
\hline 2004 & Yes & Yes & Yes & No & & Yes \\
\hline 2005 & No & Yes & Yes & No & & Yes \\
\hline
\end{tabular}

\section{Site Amenities}

$\begin{array}{cccccc}\begin{array}{c}\text { Program } \\ \text { Year }\end{array} & \begin{array}{c}\text { Covered } \\ \text { Bicycle Spaces }\end{array} & \begin{array}{c}\text { Uncovered } \\ \text { Bicycle Spaces }\end{array} & \begin{array}{c}\text { Clothes } \\ \text { Lockers }\end{array} & \text { Showers } & \begin{array}{c}\text { Non-SOV On-site } \\ \text { Loading/Unloading }\end{array} \\ 1999 & \text { No } & \text { Yes } & \text { No } & \text { No } & \text { No } \\ 2000 & \text { No } & \text { Yes } & \text { No } & \text { No } & \text { No } \\ 2001 & \text { No } & \text { Yes } & \text { No } & \text { No } & \text { No } \\ 2002 & \text { Yes } & \text { Yes } & \text { No } & \text { No } & \text { No } \\ 2003 & \text { Yes } & \text { Yes } & \text { No } & \text { No } & \text { No } \\ 2004 & \text { Yes } & \text { Yes } & \text { No } & \text { No } & \text { No } \\ 2005 & \text { Yes } & \text { Yes } & \text { No } & \text { No } & \text { No }\end{array}$

\section{Financial Subsidies, Incentives or Allowances}

$\begin{array}{ccccc}\begin{array}{c}\text { Program } \\ \text { Year }\end{array} & \begin{array}{c}\text { Transit Subsidy } \\ \text { (Employee/Month) }\end{array} & \begin{array}{c}\text { Vanpool Subsidy } \\ \text { (Employee/Month) }\end{array} & \begin{array}{c}\text { Carpool Subsidy } \\ \text { (Employee/Month) }\end{array} & \begin{array}{c}\text { Walking Subsidy } \\ \text { (Employee/Month) }\end{array} \\ 2099 & 0 & 0 & 0 & 0 \\ 2001 & \$ 15 & 0 & \$ 15 & \$ 15 \\ 2002 & \$ 15 & 0 & \$ 0.75 / \text { Day } & \$ 0.75 / \text { Day } \\ 2003 & \$ 15 & 0 & \$ 24 & \$ 29 \\ 2004 & \$ 15 & 0 & \$ 24 & \$ 29.00 \\ 2005 & \$ 15 & 0 & \$ 26 & \$ 28.00 \\ & \$ 15 & 0 & \$ 26 & \$ 28\end{array}$




$\begin{array}{cccc}\begin{array}{c}\text { Program } \\ \text { Year }\end{array} & \begin{array}{c}\text { Ferry Subsidy } \\ \text { (Employee/Month) }\end{array} & \begin{array}{c}\text { Bicycling Subsidy } \\ \text { (Employee/Month }\end{array} & \begin{array}{c}\text { Other Stipend } \\ \text { (Employee/Month) }\end{array} \\ 1999 & 0 & 0 & 0 \\ 2000 & 0 & \$ 15 & 0 \\ 2001 & 0 & \$ 0.75 / \text { Day } & 0 \\ 2002 & 0 & \$ 25 & 0 \\ 2003 & 0 & \$ 25 & 0 \\ 2004 & 0 & \$ 26 & 0 \\ 2005 & 0 & \$ 26 & 0\end{array}$

\section{Fleet Vehicles and Special Programs}

\section{Employer provided vehicles availability}

$\begin{array}{cccccc}\begin{array}{c}\text { Program } \\ \text { Year }\end{array} & \begin{array}{c}\text { FV Guaranteed } \\ \text { Ride Home }\end{array} & \text { FV Vanpool } & \begin{array}{c}\text { FV } \\ \text { Carpool }\end{array} & \begin{array}{c}\text { FV Work- } \\ \text { Related Trips }\end{array} & \begin{array}{c}\text { FV Non-Work } \\ \text { Related Errands }\end{array} \\ 1999 & \text { No } & \text { No } & \text { No } & \text { No } & \text { No } \\ 2000 & \text { No } & \text { No } & \text { No } & \text { No } & \text { No } \\ 2001 & \text { No } & \text { No } & \text { No } & \text { No } & \text { No } \\ 2002 & \text { No } & \text { No } & \text { No } & \text { Yes } & \text { No } \\ 2003 & \text { No } & \text { No } & \text { No } & \text { Yes } & \text { No } \\ 2004 & \text { No } & \text { No } & \text { No } & \text { Yes } & \text { No } \\ 2005 & \text { No } & \text { No } & \text { No } & \text { Yes } & \text { No }\end{array}$

\section{Other services availability}

$\begin{array}{cccc}\text { Program } & \text { Employer-Provided } & \text { Guaranteed Ride Home } & \text { Internal Match } \\ \text { Year } & \text { Shuttle } & \text { Program } & \\ 1999 & \text { No } & \text { Yes } & \\ 2000 & \text { No } & \text { Yes } & \\ 2001 & \text { No } & \text { Yes } & \\ 2002 & \text { No } & \text { Yes } & \text { Yes } \\ 2003 & \text { No } & \text { Yes } & \text { Yes } \\ 2004 & \text { No } & \text { Yes } & \text { Yes } \\ 2005 & \text { No } & \text { Yes } & \text { Yes }\end{array}$

\section{Mode Split and Vehicle Miles Traveled}

\begin{tabular}{ccccccc}
$\begin{array}{c}\text { Program } \\
\text { Year }\end{array}$ & \multicolumn{2}{c}{$\begin{array}{c}\text { Num of Surveys } \\
\text { Distributed (Num of }\end{array}$} & $\begin{array}{c}\text { Total Reported } \\
\text { Commuting Days }\end{array}$ & $\begin{array}{c}\text { Driving } \\
\text { Alone }\end{array}$ & Carpooling & Vanpooling \\
1997 & 107 & & 398 & $95.7286 \%$ & $0.5025 \%$ & $0.0000 \%$ \\
1999 & 88 & & 299 & $88.9632 \%$ & $3.0100 \%$ & $0.0000 \%$ \\
2001 & 93 & & 303 & $92.0792 \%$ & $2.3102 \%$ & $0.0000 \%$ \\
2003 & 122 & & 468 & $83.7607 \%$ & $9.8291 \%$ & $0.0000 \%$ \\
Program & Public & Bicycling & Walking & Other & Vehicle Miles & \\
Year & Transit & & & & Traveled & \\
1997 & $0.0000 \%$ & $0.0000 \%$ & $2.0101 \%$ & $1.7588 \%$ & 8.87 & \\
1999 & $2.6756 \%$ & $1.6722 \%$ & $3.3445 \%$ & $0.3344 \%$ & 9.47 & \\
2001 & $1.9802 \%$ & $0.0000 \%$ & $1.6502 \%$ & $1.9802 \%$ & 7.98 & \\
2003 & $1.7094 \%$ & $1.2821 \%$ & $2.3504 \%$ & $1.0684 \%$ & 7.81 &
\end{tabular}

\section{Compressed Work Week, Flex Time and Teleworking}

Policy (2001)

Flex Time

Teleworking
At the discretion of the Director of each department Flex Time maybe granted as long as the operation of the department is not jeopardized or interrupted by such a schedule.

Same as flex time 


\section{Percentage of employees on Compressed Work}

$\begin{array}{ccccc}\begin{array}{c}\text { Program } \\ \text { Year }\end{array} & \begin{array}{c}\text { Num of Surveys } \\ \text { Distributed (Affected }\end{array} & \begin{array}{c}\text { Total Surveys } \\ \text { Reported }\end{array} & \begin{array}{c}\text { Percentage of Employees } \\ \text { On 5 Days/Week }\end{array} & \begin{array}{c}\text { Percentage of Employees } \\ \text { On 3 Days/Week }\end{array} \\ 1997 & 107 & 80 & 92.5000 \% & 0.0000 \% \\ 1999 & 88 & 62 & 95.1613 \% & 0.0000 \% \\ 2001 & 93 & 63 & 93.6508 \% & 1.5873 \% \\ 2003 & 122 & 100 & 91.0000 \% & 2.0000 \% \\ \text { Program } & \text { Percentage of Employees } & \text { Percentage of Employees } & \text { Percentage of Employees } \\ \text { Year } & \text { On 4 Days/Week } & \text { On 7 Days/Two Weeks } & \text { On 9 Days/Two Weeks } \\ 1997 & 3.7500 \% & 0.0000 \% & 1.2500 \% \\ 1999 & 1.6129 \% & 0.0000 \% & 1.6129 \% \\ 2001 & 4.7619 \% & 0.0000 \% & 0.0000 \% \\ 2003 & 0.0000 \% & 0.0000 \% & 6.0000 \%\end{array}$

Percentage of employees on Telecommuting

\begin{tabular}{|c|c|c|c|c|c|}
\hline $\begin{array}{l}\text { Program } \\
\text { Year }\end{array}$ & \multicolumn{2}{|c|}{$\begin{array}{l}\text { Num of Surveys Distributed } \\
\text { (Num of Affected Employees) }\end{array}$} & $\begin{array}{l}\text { Total Surveys } \\
\text { Reported }\end{array}$ & $\begin{array}{l}\text { Total Percentage } \\
\text { of Telecommuters }\end{array}$ & $\begin{array}{l}1 \text { Days every } \\
\text { Two Weeks }\end{array}$ \\
\hline 1997 & \multicolumn{2}{|c|}{107} & 81 & $1.2346 \%$ & $1.2346 \%$ \\
\hline 1999 & \multicolumn{2}{|c|}{88} & 60 & $0.0000 \%$ & $0.0000 \%$ \\
\hline 2001 & \multicolumn{2}{|c|}{93} & 58 & $0.0000 \%$ & $0.0000 \%$ \\
\hline 2003 & \multicolumn{2}{|c|}{122} & 101 & $8.9109 \%$ & $4.9505 \%$ \\
\hline $\begin{array}{c}\text { Program } \\
\text { Year }\end{array}$ & 2 Days every & 3 Days & $\begin{array}{l}4 \text { Days every } \\
\text { Two Weeks }\end{array}$ & $\begin{array}{l}5 \text { Days every } \\
\text { Two Weeks }\end{array}$ & $\begin{array}{c}\text { More than } 5 \\
\text { Davs every Two }\end{array}$ \\
\hline 1997 & $0.0000 \%$ & $0.0000 \%$ & $0.0000 \%$ & $0.0000 \%$ & $0.0000 \%$ \\
\hline 1999 & $0.0000 \%$ & $0.0000 \%$ & $0.0000 \%$ & $0.0000 \%$ & $0.0000 \%$ \\
\hline 2001 & $0.0000 \%$ & $0.0000 \%$ & $0.0000 \%$ & $0.0000 \%$ & $0.0000 \%$ \\
\hline 2003 & $1.9802 \%$ & $0.9901 \%$ & $0.0000 \%$ & $0.0000 \%$ & $0.9901 \%$ \\
\hline
\end{tabular}




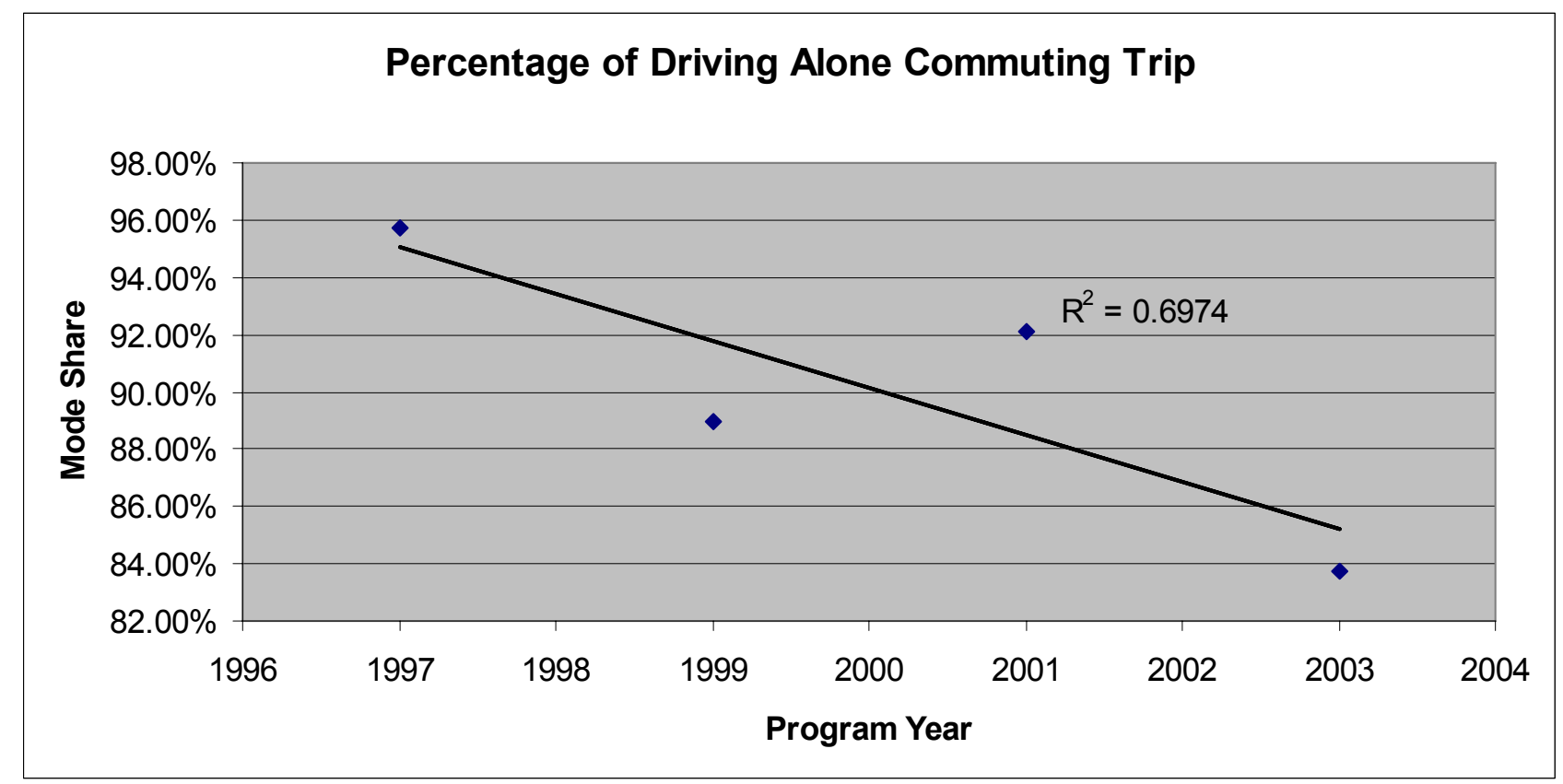

Figure 15: Percentage of Drive-Alone Commute Trips - St. Joseph Hospital

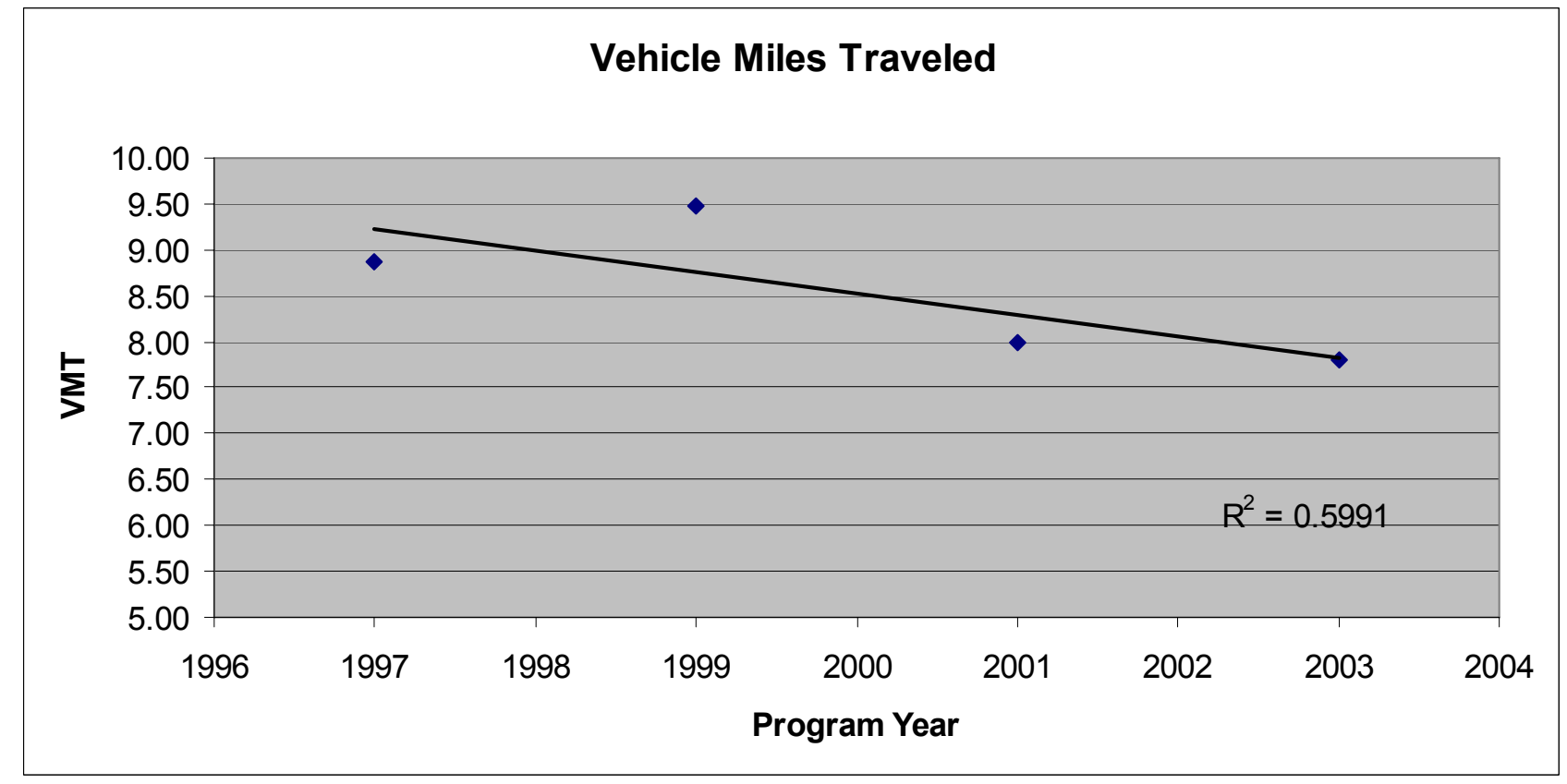

Figure 16: VMT - St. Joseph Hospital 


\section{South Seattle Community College (SSCC), West Seattle Campus}

Seattle, Washington

\section{Keys to Success}

The SSCC West Seattle Campus trip reduction program is required through the Washington State Commute Trip Reduction (CTR) Law. It is successful despite its suburban location and very minor traffic congestion conditions. The greater issue is worksite access from across the larger region. There are enough employees for whom cost savings through use of alternative transportation, primarily carpooling and public transit, is more important than time savings by driving one's personal vehicle. A quarterly Transportation Management Fee funds subsidies and incentives that encourage use of alternative transportation by employees and students alike.

\section{Results and Cost}

The SSCC CTR Program performance trends indicate that the average one-way vehicle miles traveled per commute trip decreased from 11 miles in 1993 to 9.7 miles in 2003. The percentage of affected employees who drive alone decreased from 89 percent in 1993 to 68 percent in 2003. Carpooling increased from 9.9 percent in 1993 to 21.4 percent in 2003. Mode share for public transit increased from 0.9 percent in 1993 to 8 percent in 2003. Results also show that a small number of employees are also walking and bicycling to work and close to two percent are telecommuting. None of these modes were represented in the 1993 data. The data also indicate that over 8.5 percent of employees work on a compressed work week schedule and some of these employees also use alternative transportation modes. The Employee Transportation Coordinator (ETC) estimated that last year's annual cost of the CTR program was approximately $\$ 160,000$ to $\$ 200,000$, including labor, subsidies and the operation of a free shuttle.

\section{Organization Mission}

Interestingly, the SSCC motto uses a travel analogy: "Start here, go anywhere." The mission of SSCC is "South Seattle Community College is a constantly evolving educational community dedicated to providing quality learning experiences which prepare students to meet their goals for life and work. The College values and promotes a close involvement with the community and strong partnerships with business, labor and industry." The SSCC ETC confirmed that community relations are at the top of the list in importance to SSCC. He said the main qualities that SSCC wants to be known for are graduating successful students and being a good community neighbor.

While SSCC is required to participate in the Washington State CTR Program, the ETC perceives that the CTR Program and the SSCC mission are philosophically aligned and travel demand management activities of SSCC are integrated with the way business is conducted. The only conflict the ETC experiences between the CTR program and SSCC is that efforts to do special commute alternative promotions with 'giveaways' are disallowed due to prohibitions on the use of State funds. He is frustrated that state funds from the community college system are not permitted to be used by the SSCC to advance the state-required CTR program. 


\section{South Seattle Community College (SSCC), West Seattle Campus}

\section{Seattle, Washington}

\section{External Factors}

The SSCC West Seattle campus is located in a suburban commercial and residential area. The ETC said that the campus site was originally a gravel pit. The campus is in a good location to serve the targeted local commuter student population. At the time of its development, the land parcel was of sufficient acreage for a campus and at a reasonable cost for the land. Employee accessibility and traffic congestion reduction were less primary considerations for the location of the campus than access to the target educational market.

The ETC describes traffic congestion as a " 5 " on a scale of " 1 " to " 10 " " 1 " being free-flow and "10" being gridlock) and this midpoint level of traffic has stayed about the same over the past year. Local transit service arrives every 15 minutes during peak hours. The ETC says that while transit service in Seattle is good, it has always been more of a challenge to provide adequate East/West service due to the topography and water features of the area. Outside the City, transit service is less available and less frequent. Using transit to commute to SSCC would require one or more transfers and take far longer than driving one's car.

\section{Commuter Characteristics}

SSCC employs approximately 465 employees, of whom 160 are affected by the CTR program, and serves over 5,100 students. Approximately 56 percent of the students are full time. SSCC is a commuter campus. The level of traffic congestion fluctuates during the school year as is characteristic of a college campus. More congestion is experienced at the beginning of the Fall Quarter, when students are going through orientation and many are still learning their way around the campus, establishing class and work schedules and finalizing travel arrangements. For employees who use alternative modes, the ETC says that cost savings is the main motivator and for those who continue to drive alone to work, time savings and freedom are the main motivators. Many employees cannot afford to live within the City. Some employees travel as far as 90 miles one way to SSCC.

\section{Parking}

The price of parking goes up every year. The ETC says that people always complain but they still always pay to park. The quarterly Transportation Management Fees (TMF) paid by both employees and students support the CTR program. The parking fees go into the maintenance and running of the parking lots, lighting and security in the parking lots. The ETC feels that he has some influence over the budget for the CTR program because his direct supervisor, the Vice President of Administrative Services, is responsible for the CTR program budget. The ETC also feels that he has influence upon the strategies and services provided as part of the CTR program because he meets with his counterparts at the other SSCC campuses and they talk over their ideas and decide how to coordinate their programs.

There are a total of 1,112 paid parking spaces on-site for both students and staff. Paid parking is required Monday through Saturday and can be purchased on a daily, quarterly or annual basis. There are two parking lots for employees. There is plenty of parking availability for employees 


\section{South Seattle Community College (SSCC), West Seattle Campus}

\section{Seattle, Washington}

but the location of the parking may not be convenient for all employees. Parking is free for vanpoolers. There are 100 designated carpool/vanpool spaces, which were added in 2004 but they do not work well as a perk. Employees who carpool often do not use the carpool spaces because they may not be most conveniently located near their campus destination. The carpool spaces are actually used more by students. The ETC said that registered carpoolers will use the carpool spaces because the parking lots fill up quickly. Citations are given to drivers of single occupant vehicles who use carpool spaces and to registered carpoolers who do not use the designated carpool spaces. The majority of fees and citations collected are used for maintenance and upkeep of the parking lots.

There are 185 free off-site parking spaces that are less conveniently located. The campus is surrounded by residential areas and especially during the beginning of the Fall Quarter, students will park for free in front of residential homes, blocking mail boxes and driveways. A few years ago, neighborhood residents complained. The SSCC and the City suggested residential parking permits administered at the expense of the college, but the neighborhoods did not want a parking permitting program because it would also limit parking for their own guests. Ultimately, nothing was done and the neighbors now complain only infrequently.

\section{On-Site Amenities}

The campus has covered bicycle parking, clothes lockers and showers. SSCC is a three-campus district and offers a free shuttle among campus sites, including the main West Seattle campus, the Duwamish campus and the New Holly campus. The shuttle can make additional stops en route. Each shuttle run requires an hour and the shuttle operates four runs in the morning, departing SSCC at 6:00, 7:00, 8:00 and 9:30 a.m. In the afternoons, the shuttle runs at 12:35, 1:35, 2:35, 3:35 and 4:45 p.m. The ETC is most glad about seeing the campus shuttle full of people, especially since a large part of the CTR program budget goes toward operation of the shuttle. He least likes getting a call from students who say they have missed the shuttle. The ETC cannot contact the shuttle driver. The shuttle driver has a cell phone but he won't use it. SSCC contracts out the operation of the shuttle.

The main West Seattle Campus also provides a transit stop on-site, sidewalks, a cafeteria and pastry shop, a child care center, a bookstore and an automated teller machine. Due to the campus location, employees generally do not leave the campus during lunch to run errands. The SSCC web site provides a link to King County Metro's online trip planner, transit timetables, pass sales and ridesharing services. Since 2003, an internal ridematching service has been offered.

The ETC observed that for the 26 years he has worked at SSCC, there has always been an informal commuter assistance program, including discounts for people who carpool. At the time of the passage of the State Commute Trip Reduction Law in 1993, SSCC made their program more formal and started charging the TMF to subsidize the vouchers that are given out and the bus passes. 


\section{South Seattle Community College (SSCC), West Seattle Campus}

\section{Seattle, Washington}

\section{Commute Options for Employees}

Employees at the community college are a mix of different job types. It is primarily a unionized workforce that includes blue-collar, white-collar, professionals and highly skilled workers. These include faculty, administrators, clerical staff, custodians, security personnel, and facilities maintenance staff. Most employees work during the day but two full-time security personnel work the swing shift and 14 custodians work the graveyard shift. Several part-time faculty members teach during the evenings. The ETC recognizes that full-time employees of SSCC West Seattle campus may be in a better position to use commute alternatives than hourly employees. For example, some instructors teach classes at the West Seattle campus, then later in the day must travel to another SSCC location to teach. Employees who work more predictable, routine full-time schedules would have better opportunities to form carpools as well as take transit.

The CTR Program was not originally tailored for any particular type or group of employees. Among employees of SSCC, the ETC observes that there are some distinctions by department with regard to receptivity to commute alternatives. For example, office employees tend to be more receptive to commute alternatives than other types of personnel, such as facilities maintenance employees. He also has observed over the years, that there is a general increase in employee receptivity toward commute alternatives due to a greater awareness of the environment as well as newer employees tend to be younger. Employees who use alternative modes tend to favor carpooling. A carpool is considered one if two or more persons share a ride for 50 percent or more of the commute. The ETC observes that carpooling is especially popular between spouses, one of whom usually does not work at SSCC.

For employees who work more than 20 hours per week and park on campus, they must pay the $\$ 10$ quarterly TMF. If the employee parks off campus, the Fee is not imposed. Employees may purchase reserved parking at premium rates ( $\$ 27.75$ per month) in addition to a required $\$ 10$ quarterly TMF. Carpool parking spaces are reserved and available at half price $(\$ 13.42$ per month). Employees who work 20 hours or more per week and pay a $\$ 10$ per quarter TMF and do not pay for parking can receive a quarterly Go-Pass (two-zone peak bus pass) for the price of the TMF, when it would ordinarily cost approximately $\$ 250$.

Employees who work less than 20 hours per week can purchase a quarterly Go-Pass for $\$ 110$. Employees who vanpool receive Commuter bonus Vouchers worth $\$ 35$ per quarter per person and free vanpool parking, although few employees vanpool. While carpooling is the top commute alternative, it is unclear why vanpooling is seldom used. Employees travel to SSCC from all over the region, some commuting as far away as 90 miles one way. The ETC thinks that the advantages of vanpooling are less useful partly due to the college's centralized and accessible location to its local market. Employees may also ride the free shuttle to campus. Employees who use the ferry receive a subsidy of $\$ 58$ per month.

Employees who carpool, walk or bicycle at least three times per week are also eligible for Commuter Bonus Vouchers, which entitle them to alternative commute-related merchandise and services worth $\$ 35$ per quarter, such as fuel, oil changes, bicycle gear, car washes, and walking 


\section{South Seattle Community College (SSCC), West Seattle Campus}

\section{Seattle, Washington}

shoes from participating vendors. Retailers include Union 76 gas stations, REI outdoor equipment, Brown Bear Car Wash, YMCA, AAA of Washington, Flexcar and the SSCC bookstore. Employees are also eligible for a guaranteed free emergency taxi ride home up to eight times per year and 60 miles one way, although this service is seldom used. SSCC also has a Flexcar available free to its employees who are carpool passengers, walkers, bicyclists or transit riders. Employees can sign up to use the car for any purpose during the day.

\section{Commute Options for Students}

Students enrolled for 10 or more credits per quarter must pay the quarterly $\$ 10 \mathrm{TMF}$, regardless of whether they park on or off campus or use alternative transportation. The fee qualifies them for subsidies on monthly and quarterly bus passes and bonus plus vouchers for carpoolers, walkers and bicyclists. Students who have paid the TMF are eligible to purchase a discounted Go-Pass, which can be used for Metrobus trips valued up to \$4, anytime and anywhere in King County, as well as Sound Transit Express bus service, Sounder Train and the summer Water Taxi. A student who is taking 10 credits or more and does not purchase a parking permit can purchase a quarterly Go-Pass for one-third the price, at $\$ 67$.

Students enrolled for less than 10 credits can purchase a quarterly Go-Pass for $\$ 110$. A student who does purchase a parking permit can still get a Go-Pass at an unsubsidized price which is less expensive than purchasing directly from Metro. A student can also purchase a pass from another transit agency, like Ship-To-Shore or Community Transit, and be reimbursed up to $\$ 45$ quarterly. Full time students who carpool, walk or bicycle to campus may be eligible for Commuter Bonus Plus Vouchers worth $\$ 35$ of commute-related merchandise each quarter from participating retailers.

Quarterly parking fees are based upon the number of enrolled credits. The quarterly parking fee for a full-time student is $\$ 46.50$. The quarterly fee for a carpool is $\$ 25.75$. Daily permits are $\$ 2.00$. Students who are taking less than 10 credits and who do not purchase a parking permit can get a Go-Pass for half the price. Students who are taking less than 10 credits and who purchase a parking permit can not purchase a discounted Go-Pass. Students can arrange to be picked up by the free campus shuttle at a non-scheduled stop along the route by contacting the Supervisor of Security and Transportation the day before the service is needed.

\section{Employee Transportation Coordinator}

The Supervisor for Security and Transportation in Administrative Services was interviewed for this case study. He has been employed at SSCC for 26 years and has served in the capacity of the Employee Transportation Coordinator for 14 years. He was assigned the job of ETC. He has his own office located in the Student Services Building. His ETC duties are explicitly listed as part of his written job description. The ETC finds outside support for the CTR program from an ETC network. He has completed a training and program development class. The duties as ETC are not his primary work responsibilities. His primary duties are in security but he adds that security and commute alternatives promotion complement each other. He spends an average of 17 hours per week on ETC duties, which include overseeing shuttle operation, providing 


\section{South Seattle Community College (SSCC), West Seattle Campus}

\section{Seattle, Washington}

alternative commute information to new employees, posting materials, giving presentations to employees, conducting special events, publishing CTR articles and distributing ridematch information. Since 2002, the ETC has also been giving presentations to management.

The ETC's job performance is partly evaluated on his work on the CTR program, although it is not tied to the CTR program results. He says management supports him in his work as an ETC by "leaving me alone and letting me do my job, which I guess is a good thing." The ETC also says that his work does not require a lot of coordination with other departments at SSCC and he can carry out his ETC duties essentially on his own. The ETC thinks that his most important task as ETC is to inform people of the CTR program. While there is an extensive summary of CTR program elements, he notes that people react to it like "a deer staring at headlights" - it is so much information. He tries to make the program understandable by providing information in bits and pieces in one-on-one conversations. The ETC previously distributed written brochures but now primarily uses email to promote the CTR program. He may send out emails whenever he chooses. He said he is happy with his job and he knows commute alternatives are difficult to sell but he does not let that discourage him.

The ETC interacts often with employees who provide complaints about transportation and parking as well as suggestions for the CTR program. He said that while he talks frequently about the program to employees, he feels that the success of the program happens with little effort. The ETC has received two Diamond Awards for Parking Management and the Governor's CommuterSmart Award but he says he is not sure exactly what he did to get these awards. The program is in place and people use it. 
Organization Information (2005)

South Seattle Community College

Seattle, WA

Website:

www.sccd.ctc.edu

Primary Business:

Education

Non-profit organization? Yes

Total Employees: $\quad 465$

Affected Employees: $\quad 160$

Is the CTR program subject to collective bargaining? Yes

Does this worksite have multiple shifts? Yes

Shifts description:

(2) fulltime Security work swing shift,(14) custodians work graveyard and a number

of part-time faculty teach nights.

\section{CTR program contact:}

David Lantry

King County Metro

400 Yesler Way, MS YES-TR-0650, Seattle, WA 98104

Phone: (206) 684-1139

Email: david.lantry@metrokc.gov

Worksite Characteristics (2005)

$\begin{array}{cccccc}\text { Bus stop(s) } & \text { Bike lane } & \text { Sidewalks } & \text { Restaurants } & \text { Shopping } & \text { Bank } \\ \text { Availability } & \text { Availability } & \text { Availability } & \text { Availability } & \text { Availability } & \text { Availability } \\ \text { Onsite } & \text { Not available } & \text { Onsite } & \text { Onsite } & \text { Onsite } & \text { Onsite }\end{array}$

Program Narrative (2001)

Employees carpooling, walking, or riding a bicycle are eligible for reduced parking fee along with reserved carpool parking, $\$ 35$ commuter bonus vouchers per quarter, home free guarantee i.e. taxi ride home up to 8 times a year and 60 miles one way if there is an unexpected emergency, pay a $\$ 10$ per quarter Transportation plan fee and receive a go-pass (two zone peak bus pass), free vanpool parking with $\$ 35$ per quarter per person to subsidize vanpoolers, and free shuttle to campus. Carpoolers must carpool at least 3 days a week, walkers and bicyclists registered to commute in this mode three times a week will receive the commuter Bonus vouchers to buy products related to their commute, example BP gas, Firestone (Oil changes), REI (bike gear), and Brown Bear car. Employees at $50 \%$ or more paying a \$10.00 Transportation Management fee are eligible to receive a quarterly Go-pass. The Transportation management fee is mandatory for those at $50 \%$ or more and want to purchase parking, students with(10) or more credits may purchase a quarterly Go-pass for $\$ 67.00$, employees under (*10) credits may purchase a quarterly Go-pass for $\$ 110$ 


\section{Worksite Parking and Parking Management Information}

\section{Parking management and monitoring (2005)}

Employees pay for parking through payroll deduction or at the cashiers and have a parking permit

\section{Parking}

$\begin{array}{cc}\text { Program } & \text { Total Num of } \\ \text { Year } & \text { Employees } \\ 1999 & 459 \\ 2000 & 459 \\ 2001 & 500 \\ 2002 & 445 \\ 2003 & 515 \\ 2004 & 465 \\ 2005 & 465 \\ \text { Program } & \text { Leased Offsite } \\ \text { Year } & \text { Parking Spaces } \\ 1999 & 0 \\ 2000 & 0 \\ 2001 & 0 \\ 2002 & 0 \\ 2003 & 0 \\ 2004 & 0 \\ 2005 & 0\end{array}$

Onsite Parking
Spaces
905
974
953
953
946
1112
1112

Leased Onsite Parking Price (Space/Month)
Offsite Parking Leased Onsite

Spaces Parking Spaces

185

185

185

185

185

120

185

85

Leased Offsite Parking

Price (Space/Month)

\section{Parking management}

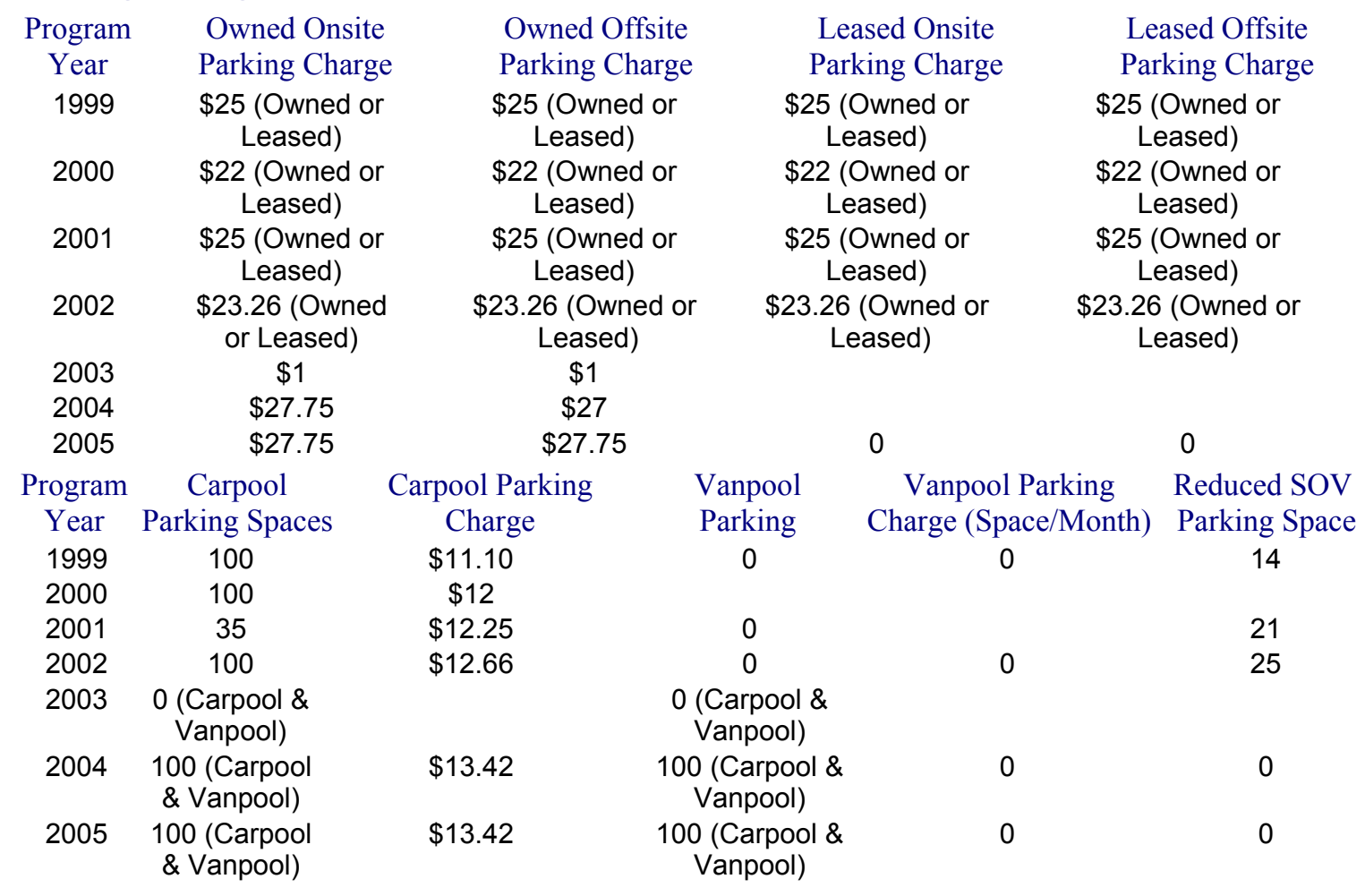




\section{Program Promotion}

\section{General (2005)}

Is the ETC's name, location and telephone number prominently displayed at this Yes

Displayed where? Robert Smith Building

Has the ETC completed a program developer/ETC training course? Yes

On average, how many hours per week does the ETC spend on CTR activities? 17

Does the ETC have an active worksite committee to assist with the CTR No

\section{Program promotion}

\begin{tabular}{|c|c|c|c|c|c|c|}
\hline $\begin{array}{l}\text { Program } \\
\text { Year }\end{array}$ & Distribute & \multicolumn{3}{|c|}{ Provide CTR Program } & $\begin{array}{c}\text { Post } \\
\text { Materials }\end{array}$ & $\begin{array}{c}\text { Give Managers } \\
\text { Presentation }\end{array}$ \\
\hline 1999 & Yes & & Yes & & Yes & No \\
\hline 2000 & Yes & & Yes & & Yes & No \\
\hline 2001 & Yes & & Yes & & Yes & No \\
\hline 2002 & Yes & & Yes & & Yes & Yes \\
\hline 2003 & Yes & & Yes & & Yes & No \\
\hline 2004 & Yes & & Yes & & Yes & Yes \\
\hline 2005 & Yes & & Yes & & Yes & Yes \\
\hline Program & Give & Conduct & Publish & Dist & bute & Distribute \\
\hline Year & Employees & CTR Events & CTR Articles & Informa & on with & Ridematch \\
\hline 1999 & Yes & Yes & No & $\mathrm{Nc}$ & & Yes \\
\hline 2000 & Yes & Yes & No & $\mathrm{No}$ & & Yes \\
\hline 2001 & Yes & No & No & No & & Yes \\
\hline 2002 & Yes & Yes & Yes & No & & Yes \\
\hline 2003 & Yes & Yes & Yes & $\mathrm{No}$ & & Yes \\
\hline 2004 & Yes & Yes & Yes & $\mathrm{No}$ & & Yes \\
\hline 2005 & Yes & Yes & Yes & $\mathrm{No}$ & & Yes \\
\hline
\end{tabular}

\section{Site Amenities}

$\begin{array}{cccccc}\begin{array}{c}\text { Program } \\ \text { Year }\end{array} & \begin{array}{c}\text { Covered } \\ \text { Bicycle Spaces }\end{array} & \begin{array}{c}\text { Uncovered } \\ \text { Bicycle Spaces }\end{array} & \begin{array}{c}\text { Clothes } \\ \text { Lockers }\end{array} & \text { Showers } & \begin{array}{c}\text { Non-SOV On-site } \\ \text { Loading/Unloading }\end{array} \\ 1999 & \text { Yes } & \text { No } & \text { Yes } & \text { Yes } & \text { No } \\ 2000 & \text { Yes } & \text { No } & \text { Yes } & \text { Yes } & \text { No } \\ 2001 & \text { Yes } & \text { No } & \text { Yes } & \text { Yes } & \text { No } \\ 2002 & \text { Yes } & \text { No } & \text { Yes } & \text { Yes } & \text { No } \\ 2003 & \text { Yes } & \text { No } & \text { Yes } & \text { Yes } & \text { No } \\ 2004 & \text { Yes } & \text { No } & \text { Yes } & \text { Yes } & \text { Yes } \\ 2005 & \text { Yes } & \text { No } & \text { Yes } & \text { Yes } & \text { No }\end{array}$

\section{Financial Subsidies, Incentives or Allowances}

$\begin{array}{ccccc}\begin{array}{c}\text { Program } \\ \text { Year }\end{array} & \begin{array}{c}\text { Transit Subsidy } \\ \text { (Employee/Month) }\end{array} & \begin{array}{c}\text { Vanpool Subsidy } \\ \text { (Employee/Month) }\end{array} & \begin{array}{c}\text { Carpool Subsidy } \\ \text { (Employee/Month) }\end{array} & \begin{array}{c}\text { Walking Subsidy } \\ \text { (Employee/Month) }\end{array} \\ 1999 & \$ 58 & \$ 12 & \$ 12 & \$ 12 \\ 2000 & \$ 53 & \$ 35 & \$ 35 & \$ 35 \\ 2001 & \$ 58 & \$ 35 / \text { quarter } & \$ 35 / \text { quarterly } & \$ 12 \\ 2002 & \$ 57 & \$ 12 & \$ 12 & \$ 12 \\ 2003 & \$ 57 & \$ 35 & \$ 35 & \$ 35 \\ 2004 & \$ 57 & \$ 35 & \$ 35 & \$ 35 \\ 2005 & \$ 57 & \$ 35 & \$ 35 & \$ 35\end{array}$




$\begin{array}{cccc}\begin{array}{c}\text { Program } \\ \text { Year }\end{array} & \begin{array}{c}\text { Ferry Subsidy } \\ \text { (Employee/Month) }\end{array} & \begin{array}{c}\text { Bicycling Subsidy } \\ \text { (Employee/Month }\end{array} & \begin{array}{c}\text { Other Stipend } \\ \text { (Employee/Month) }\end{array} \\ 1999 & \$ 58 & \$ 12 & 0 \\ 2000 & \$ 58 & \$ 35 & 0 \\ 2001 & \$ 58 & \$ 12 & 0 \\ 2002 & \$ 58 & \$ 12 & 0 \\ 2003 & \$ 58 & \$ 35 & \$ 57 \\ 2004 & \$ 58 & \$ 35 & 0 \\ 2005 & \$ 58 & \$ 35 & 0\end{array}$

\section{Fleet Vehicles and Special Programs}

\section{Employer provided vehicles availability}

$\begin{array}{cccccc}\begin{array}{c}\text { Program } \\ \text { Year }\end{array} & \begin{array}{c}\text { FV Guaranteed } \\ \text { Ride Home }\end{array} & \text { FV Vanpool } & \begin{array}{c}\text { FV } \\ \text { Carpool }\end{array} & \begin{array}{c}\text { FV Work- } \\ \text { Related Trips }\end{array} & \begin{array}{c}\text { FV Non-Work } \\ \text { Related Errands }\end{array} \\ 1999 & \text { No } & \text { No } & \text { No } & \text { No } & \text { No } \\ 2000 & \text { No } & \text { No } & \text { No } & \text { No } & \text { No } \\ 2001 & \text { No } & \text { No } & \text { No } & \text { No } & \text { No } \\ 2002 & \text { No } & \text { No } & \text { No } & \text { Yes } & \text { No } \\ 2003 & \text { Yes } & \text { Yes } & \text { Yes } & \text { Yes } & \text { No } \\ 2004 & \text { No } & \text { No } & \text { Yes } & \text { Yes } & \text { No } \\ 2005 & \text { No } & \text { No } & \text { Yes } & \text { Yes } & \text { No }\end{array}$

\section{Other services availability}

$\begin{array}{cccc}\begin{array}{c}\text { Program } \\ \text { Year }\end{array} & \begin{array}{c}\text { Employer-Provided } \\ \text { Shuttle }\end{array} & \begin{array}{c}\text { Guaranteed Ride Home } \\ \text { Program }\end{array} & \begin{array}{c}\text { Internal Match } \\ \text { Program }\end{array} \\ 1999 & \text { Yes } & \text { Yes } & \\ 2000 & \text { Yes } & \text { Yes } & \\ 2001 & \text { Yes } & \text { Yes } & \\ 2002 & \text { Yes } & \text { Yes } & \text { Yes } \\ 2003 & \text { Yes } & \text { Yes } & \text { Yes } \\ 2004 & \text { Yes } & \text { Yes } & \text { Yes } \\ 2005 & \text { Yes } & \text { Yes } & \end{array}$

\section{Mode Split and Vehicle Miles Traveled}

\begin{tabular}{|c|c|c|c|c|c|c|c|}
\hline $\begin{array}{l}\text { Program } \\
\text { Year }\end{array}$ & \multicolumn{2}{|c|}{$\begin{array}{l}\text { Num of Surveys } \\
\text { Distributed (Num of }\end{array}$} & \multicolumn{2}{|c|}{$\begin{array}{l}\text { Total Reported } \\
\text { Commuting Days }\end{array}$} & $\begin{array}{l}\text { Driving } \\
\text { Alone }\end{array}$ & Carpooling & Vanpooling \\
\hline 1993 & 15 & & 414 & & $89.1304 \%$ & $9.9034 \%$ & $0.0000 \%$ \\
\hline 1995 & 15 & & 462 & & $84.8485 \%$ & $12.3377 \%$ & $0.0000 \%$ \\
\hline 1997 & 13 & & 409 & & $70.9046 \%$ & $23.9609 \%$ & $1.2225 \%$ \\
\hline 1999 & 15 & & 447 & & $71.5884 \%$ & $21.4765 \%$ & $0.0000 \%$ \\
\hline 2001 & 15 & & 444 & & $71.6216 \%$ & $18.9189 \%$ & $0.0000 \%$ \\
\hline 2003 & 17 & & 475 & & $67.5789 \%$ & $21.4737 \%$ & $0.0000 \%$ \\
\hline Program & Public & Bicycling & Walking & Other & & hicle Miles & \\
\hline Year & Transit & & & & & Traveled & \\
\hline 1993 & $0.9662 \%$ & $0.0000 \%$ & $0.0000 \%$ & 0.0000 & & 10.96 & \\
\hline 1995 & $1.0823 \%$ & $0.4329 \%$ & $1.2987 \%$ & 0.0000 & & 10.52 & \\
\hline 1997 & $3.4230 \%$ & $0.0000 \%$ & $0.0000 \%$ & 0.4890 & & 10.13 & \\
\hline 1999 & $6.7114 \%$ & $0.0000 \%$ & $0.0000 \%$ & 0.2237 & & 9.97 & \\
\hline 2001 & $7.4324 \%$ & $0.2252 \%$ & $1.8018 \%$ & 0.0000 & & 9.61 & \\
\hline 2003 & $8.0000 \%$ & $0.4211 \%$ & $1.0526 \%$ & 1.4737 & & 9.73 & \\
\hline
\end{tabular}




\section{Compressed Work Week, Flex Time and Teleworking}

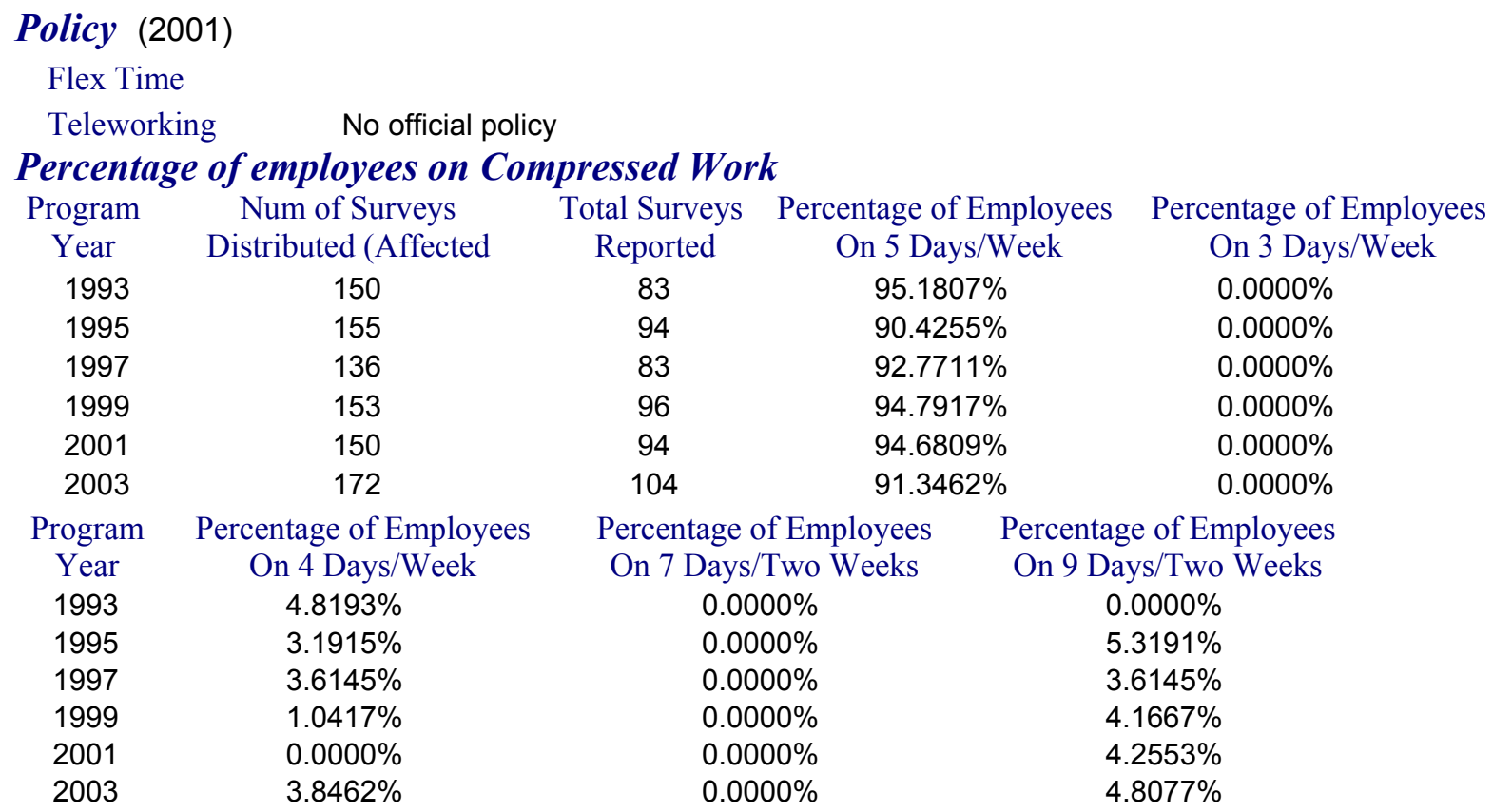

\section{Percentage of employees on Telecommuting}

\begin{tabular}{|c|c|c|c|c|c|}
\hline $\begin{array}{l}\text { Program } \\
\text { Year }\end{array}$ & \multicolumn{2}{|c|}{$\begin{array}{l}\text { Num of Surveys Distributed } \\
\text { (Num of Affected Employees) }\end{array}$} & $\begin{array}{l}\text { Total Surveys } \\
\text { Reported }\end{array}$ & $\begin{array}{l}\text { Total Percentage } \\
\text { of Telecommuters }\end{array}$ & $\begin{array}{l}1 \text { Days every } \\
\text { Two Weeks }\end{array}$ \\
\hline 1993 & \multicolumn{2}{|c|}{150} & 85 & $0.0000 \%$ & $0.0000 \%$ \\
\hline 1995 & \multicolumn{2}{|c|}{155} & 95 & $0.0000 \%$ & $0.0000 \%$ \\
\hline 1997 & \multicolumn{2}{|c|}{136} & 85 & $0.0000 \%$ & $0.0000 \%$ \\
\hline 1999 & \multicolumn{2}{|c|}{153} & 92 & $0.0000 \%$ & $0.0000 \%$ \\
\hline 2001 & \multicolumn{2}{|c|}{150} & 90 & $0.0000 \%$ & $0.0000 \%$ \\
\hline 2003 & \multicolumn{2}{|c|}{172} & 102 & $1.9608 \%$ & $0.0000 \%$ \\
\hline Program & 2 Days every & 3 Days & 4 Days every & 5 Days every & More than 5 \\
\hline Year & Two Weeks & every Two & Two Weeks & Two Weeks & Days every Two \\
\hline 1993 & $0.0000 \%$ & $0.0000 \%$ & $0.0000 \%$ & $0.0000 \%$ & $0.0000 \%$ \\
\hline 1995 & $0.0000 \%$ & $0.0000 \%$ & $0.0000 \%$ & $0.0000 \%$ & $0.0000 \%$ \\
\hline 1997 & $0.0000 \%$ & $0.0000 \%$ & $0.0000 \%$ & $0.0000 \%$ & $0.0000 \%$ \\
\hline 1999 & $0.0000 \%$ & $0.0000 \%$ & $0.0000 \%$ & $0.0000 \%$ & $0.0000 \%$ \\
\hline 2001 & $0.0000 \%$ & $0.0000 \%$ & $0.0000 \%$ & $0.0000 \%$ & $0.0000 \%$ \\
\hline 2003 & $1.9608 \%$ & $0.0000 \%$ & $0.0000 \%$ & $0.0000 \%$ & $0.0000 \%$ \\
\hline
\end{tabular}




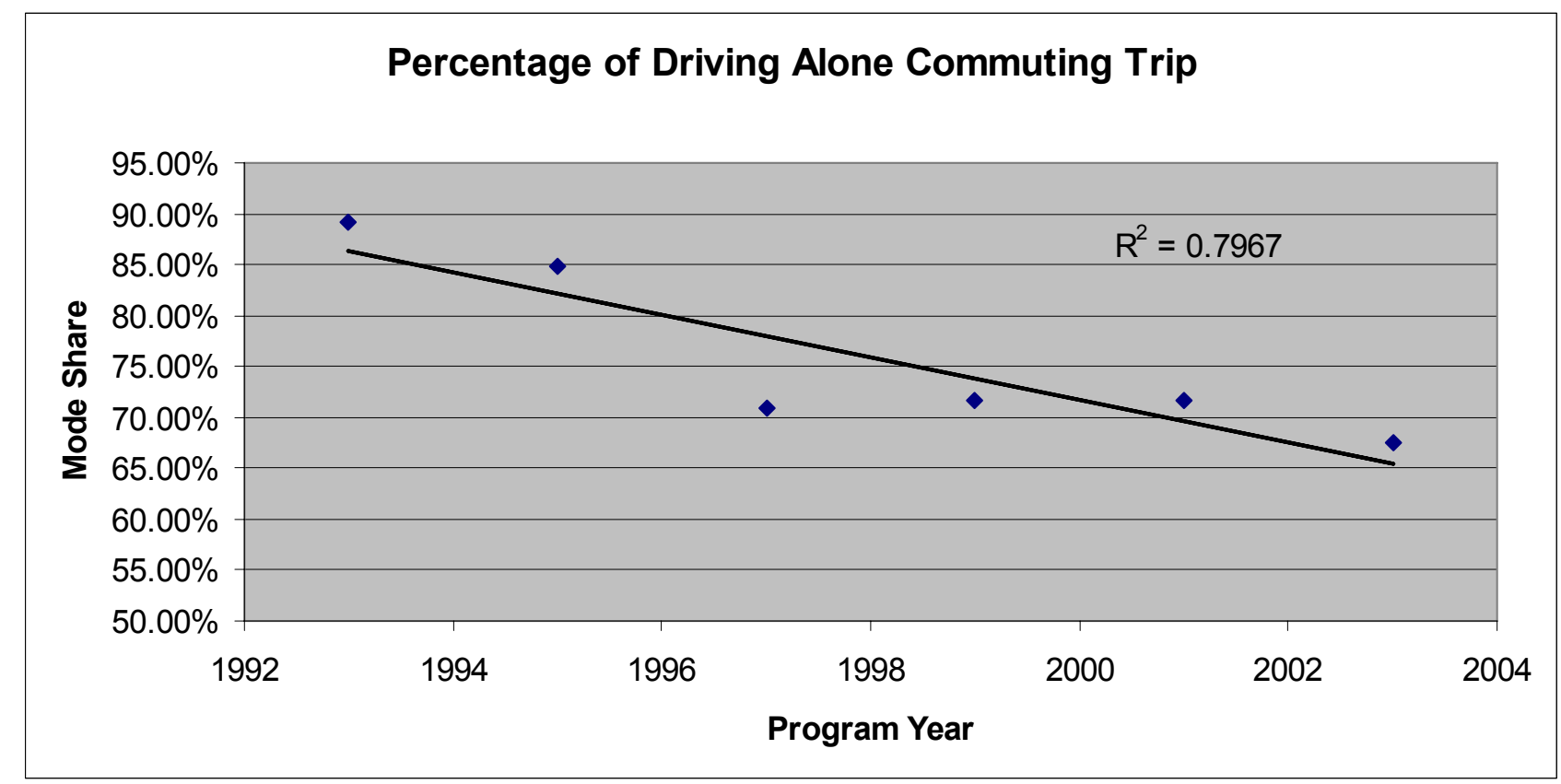

Figure 17: Percentage of Drive-Alone Commute Trips - South Seattle Community College

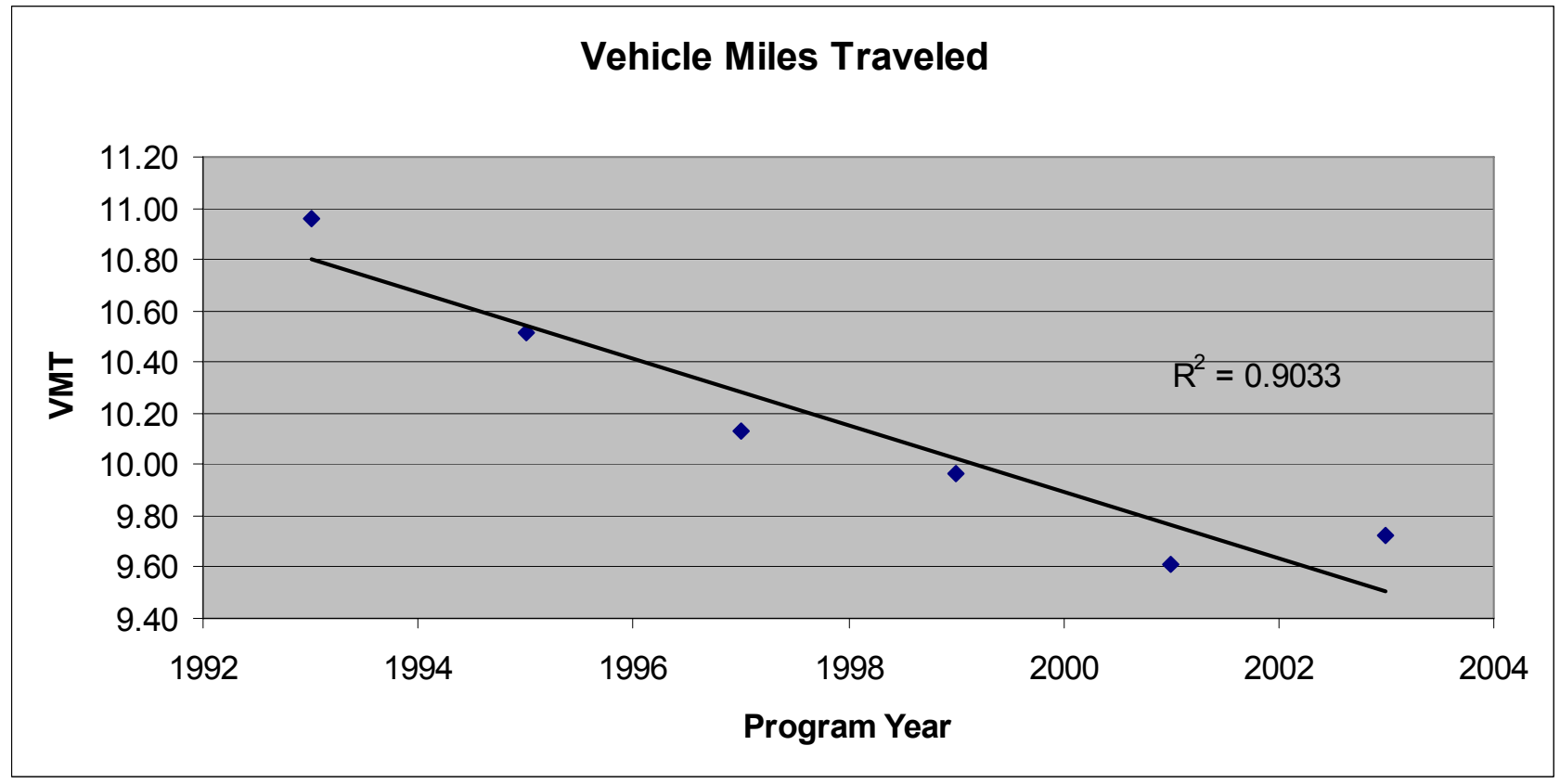

Figure 18: VMT - South Seattle Community College 


\section{Tacoma Public Utilities}

Tacoma, WA

\section{Keys to Success}

As a city service provider, Tacoma Public Utilities places a high value on community relations and improving the quality of life of the citizens of Tacoma. Their Consider Alternative Transportation (CAT) Program serves as just another way in which the company shows its commitment to the citizens of Tacoma and to its employees. The combination of significant financial support from upper level management and an Employee Transportation Coordinator (ETC) who is knowledgeable and passionate has led to a consistent reduction in single-occupant vehicle use and vehicle miles traveled per employee per day since 1993. One aspect of the program that clearly stands out is the encouragement of ridesharing as a means to socialize new employees into their open and accessible work environment.

\section{CTR Program Elements}

Tacoma Public Utilities' commute trip reduction (CTR) program consists of:

- $\$ 105 /$ month vanpool subsidy

- Free bus passes ( $\$ 45 /$ month value)

- Preferential parking for carpools and vanpools

- $\$ 7000$ annual budget for incentives, marketing and the ETC's labor

- Compressed work week program

- Employer Transportation Coordinator (ETC)

- CTR employee committee

\section{Results and Costs}

From 1993 to 2003, survey results from Washington DOT indicate that Tacoma Public Utilities reduced their drive alone mode share from 83.5 percent to 66.6 percent. In that same time frame, the vanpool mode share has increased from zero to 14.3 percent. As of October 2006, they have 30 vanpools on the road. While carpooling, bicycle and walking saw virtually no change between 1993 and 2003, the transit mode share increased from 1.3 percent to 7.5 percent. As a result of these changes, the company's average one way vehicle miles traveled (VMT) per employee has decreased from 10.44 VMT to 7.69 VMT.

The estimated annual cost of Tacoma Public Utilities' CTR program is an annual budget of $\$ 7000$ for incentives, marketing and the ETC's labor. The success of Tacoma Public Utilities' CTR program is related to both external and internal factors. 


\section{Tacoma Public Utilities}

\section{Tacoma, WA}

\section{External Factors}

While not located in the central business district of Tacoma, the worksite is well served by transit. The local transit agency, Pierce Transit, provides "almost door to door service for anyone that takes the bus" with two routes having stops directly across the street from the administration building. According to the ETC, "for those that use the bus service, it works well," although he believes that the transit mode share would be higher except for two factors. The first factor being that carpooling and vanpooling are perceived as "more efficient and more time effective" by employees and "in some ways more socially gratifying too." The second factor is that for many employees, a work trip by transit requires a transfer at either the downtown hub or the Tacoma Mall, thus increasing travel time.

The surrounding area's land use patterns also contribute to the success of their CTR program since employees do not require access to a private automobile to shop or eat during their lunch hour. While most employees are said to take advantage of a high-quality, on-site cafeteria, the surrounding area has a variety of restaurants and shops that are about a half a mile walk or bus ride from the building. According to the ETC, "some people take advantage of the restaurants, not only to take advantage of the variety of foods and prices, but also to get that walk in."

An external factor that has an impact on employee commuting, but only a slight one, is the price of gas. "When gas prices shot over $\$ 3$ per gallon, the ETC thought "people would just be coming out of the woodwork, but we did not see so much of a spike, or as much as we thought we would." He believes that the reason for the low impact is that for those employees that still drive alone to work, cost is not determining mode choice, it's "flexibility." For example, many employees have jobs that do not have regular scheduled hours or they cannot leave work until their tasks are completed. This is particularly the case with line workers in the field or customer service agents in the office who find it very difficult to participate in any kind of ridesharing arrangement. According to the ETC, some drive-alone employees were contacting him and giving alternative modes a try when gas prices were high, however, those employees were only interested in using an alternative sparingly, "maybe like two days a week, but not five." He also added that with the recent decrease in gas prices in the Fall of 2006, "no one is leaving the vanpools or carpools at all."

Perhaps the main external reason for the program's success is the support that Tacoma Public Utilities' CTR program receives from the regional ETC network organized by Pierce County's CTR Program and Pierce Transit. Several times a year, ETCs from around the region come together to receive special training, brainstorm, share ideas, and solve problems. Since the network luncheons are often linked to an upcoming promotional campaign, they also provide an opportunity to give the statewide marketing campaigns a local flavor. The ETC credits the ETC network with helping him perform his job better, but also keeping him motivated:

Here in Pierce County, the strategy here has been to get the ETCs together a few times a year to talk about upcoming promotions, training, talk about route changes, and fare increases. They do a good job, it's very engaging. They have one coming up this week. They will be talking about Wheel Options, which is a statewide promotion that they also 


\section{Tacoma Public Utilities}

\section{Tacoma, WA}

give a local flavor, they will also talk about the annual reports, and other ETC issues, like how are you responding to increasing in vanpool fares or questions on how to bicycle commute during the winter, and then we kind of brainstorm ideas and share ideas, they are great meetings.

The annual Summit Awards is another way in which the regional program provides external support to the local employers and their ETCs. The ETC, who has won several awards at the annual event, also sees it as an opportunity not only to receive recognition for himself and Tacoma Public Utilities, but also to thank his supervisor and all of upper management for their support. As he said,

Every year they have the Summit Awards, they always have a nice dinner and encourage you to invite your supervisor, because it's always nice to have your supervisor see you get a pat on the back. They always have a very good speaker, it's first class. Once our Director went, and you can't beat when your Director sees you win an award...in fact I like have the opportunity to say that in the entire county no one has matched the kind of support our management has given me. It's always a team effort because if we did not have the finances or the support that we do from upper level management, it just isn't going to happen, or let's just put it this way, it is not going to happen easily.

\section{Internal Factors}

The financial support from the upper management is perhaps the most important internal factor related to the success of Tacoma Public Utilities CTR Program. An annual budget of $\$ 7,000$ is provided to the CTR Program to cover the costs of marketing the program, purchasing prizes and incentives, and covering labor costs associated with operating the program. On January 1, 2007, the vanpool subsidy will increase to $\$ 110$ per month. In the ETC's opinion, strong financial support coupled with the recognition received as an award-winning program encourages and motivates employees to make a change:

I think that the commitment is growing a little bit because as people see our program being successful and winning awards, then they look into it a little more and makes them stop and say, may be there is something to this ridesharing stuff, and I think I will give it a try or explore it more.

The CTR Program at Tacoma Public Utilities provides a wide variety of choices and incentives. The company provides preferential parking spaces for carpools and vanpools, some of which are "closer than the Director's parking space." Soon a new parking lot will be built as a new building behind their main Administration building will be constructed. The ETC does not think this new parking lot will have a negative effect on the CTR program despite the fact that it will provide a free parking space for every employee. The reason for this belief is that the new parking lot will be further away and up on a hill, but the preferential parking for high-occupancy vehicles will remain in their current location closer to the main Administration building. According to the ETC, "the people that are (driving alone) are going to be further than ever, up a hill, and they are going to have to cross a sky bridge to get to the building." 


\section{Tacoma Public Utilities}

Tacoma, WA

The cost of commuting and, more recently, increasing traffic congestion are seen as the main reasons so many employees choose to use an alternative mode. To reduce the cost of commuting, employees presently receive a free bus pass or a vanpool subsidy of up to $\$ 105$ per month. The vanpool subsidy amount means that for virtually all vanpool riders, their commute is free. In addition to being able to commute for free by bus or vanpool, all alternative mode users automatically receive lottery scratch-off tickets as another incentive to use an alternative mode. Communication is considered critical to the CTR Program. Two times per week, an employee newsletter is distributed electronically and in hard copy. Included in the newsletter is a section on their Consider Alternative Transportation (CAT) Program entitled, CAT Mews, which highlights the CTR program and communicates important information to the employees.

Vanpooling is the most popular alternative mode with 32 vans on the road in 2006. The vanpool vehicles provided through Pierce Transit, are either 8 or 12 passenger vans since the larger 15 passenger vans have been phased out. Besides the cost savings, the ETC believes that vanpooling is the most popular because of the socializing aspect of ridesharing:

People like the vanpools and carpools, because they are not on the bus' schedule, they are on their schedule, and they are not on the bus with 20 strangers, they are with same people, their coworkers, and there is some real power there.

This socializing aspect is also promoted during the company's orientation sessions for new hires. Not only are new employees told about the cost savings of vanpooling and other alternatives to driving alone, they are also encouraged to join a vanpool or carpool to meet their new coworkers and socialize them into a new work environment. The work environment or corporate culture of the utility company also plays a role in the success of the CTR program. The ETC describes the utility company as a place in which people do not work alone as staff from different sections have to work together on planning, construction and maintenance issues. He thinks that "the corporate culture is very open" and that it "lends itself to a lot of interaction."

I think the people here feel there is a great amount of freedom of movement between the offices and support staff have easy access to the different divisions they need to work with...so I think most people would say that it's an easy going, easy access kind of organization.

As a service provider responsible to the citizens of Tacoma, the corporate culture also places a high value on community relations. Tacoma Public Utilities is a designated Best Workplace for Commuters. The CTR Program is seen as just one more way in which the company can show its commitment to making Tacoma a good place to live and do business.

In addition to having a corporate culture that values its contribution to the quality of life of Tacoma, the utility company also has an ETC who sincerely cares about improving the quality of life for his coworkers. The ETC has served in this capacity for nine years and likes the way the job "gives you personal contact with the employees." Prior to working at the utility company, the ETC worked at two different transit agencies. His years of experience and knowledge of alternative modes are critical to his ability to provide solutions to transportation problems brought to him by his coworkers. 


\section{Tacoma Public Utilities}

\section{Tacoma, WA}

In addition to the financial support provided by upper management, he also is given a fair amount of autonomy in running their CTR program. Once his budget is approved by his supervisors, he is given control over purchasing and day to day operations. Every two years, he re-evaluates the CAT Program and the budget. The ETC receives help from an employee committee that helps with the CAT Program, as well as from a number of long-time, passionate alternative mode users, who are often recognized for their own individual marketing of the program.

He estimates that the time spent overseeing the program is about 5 percent of his job. When not administering the CTR Program, he serves as the Community Relations Officer for the company. And lastly, the ETC practices what he preaches. He is a vanpool rider and an occasional bicycle commuter that often uses the local transit agency's bikes-on-bus program. 


\section{Organization Information (2004)}

\section{Tacoma Public Utilities}

Tacoma, WA

Website:

www.cityoftacoma.org

Primary Business:

Non-profit organization?

Public Utility

Total Employees:

Yes

1200

Affected Employees:

900

Is the CTR program subject to collective bargaining? No

Does this worksite have multiple shifts? Yes

Shifts description:

$7 \mathrm{am}-3: 30 \mathrm{pm}$

$7 \mathrm{am}-4: 00 \mathrm{pm}$

7:30 am - 4:30 pm

$8 \mathrm{am}-5: 00 \mathrm{pm}$

$3 \mathrm{pm}-11: 30 \mathrm{pm}$

\section{CTR program contact:}

Debbie Germer

Transportation Planner, Public Works \& Utilities

3619 Pacific Ave, Tacoma, WA 98418

Phone: (253) 798-3556

Email: dgermer@co.pierce.wa.us

\section{Worksite Characteristics (2004)}

\begin{tabular}{|c|c|c|c|c|c|}
\hline Bus stop(s) & Bike lane & Sidewalks & Restaurants & Shopping & Bank \\
\hline Availability & Availability & Availability & Availability & Availability & Availability \\
\hline
\end{tabular}

\section{Program Narrative (2001)}

The CTR program at Tacoma Public Utilities is in the third year of the CAT program (Consider Alternative Transportation) providing employees with monthly incentive prizes for ridesharing to work a minimum of twice a week. The program has 187 members. Each month, employees turn in rideshare calendars and receive a Washington State Lottery scratch ticket plus are entered into a grand prize drawing for a larger prize (perhaps a boom box or tickets to a Tacoma Sabercats hockey game). The City of Tacoma provides free vanpool fare up to $\$ 65$ per month and free bus passes. Carpoolers may receive preferential parking with two riders. If a carpool has three or more riders coming to work a minimum of $60 \%$ of the time, they may have a reserved parking space. The CAT program is highlighted weekly in the employee newsletter "Newsline" and has feature stories in the monthly publication called "Utlities". Currently the program has been running a series of elevator posters to promote ridesharing. Public Utilities participated in Rideshare Week, Smart Moves 2000 and CarLess Commute promotions. A commuter option board is located in the cafeteria and features rideshare brochures, CAT applications and calendars and employee home location map. The CTR program is managed by the ETC and the CTR committee of six employees. 


\section{Worksite Parking and Parking Management Information}

\section{Parking management and monitoring (2004)}

ETC makes random checks and security officers monitor HOV parking.

$\begin{array}{ccccc}\begin{array}{c}\text { Parking } \\ \text { Program }\end{array} & \text { Total Num of } & \text { Onsite Parking } & \text { Offsite Parking } & \text { Leased Onsite } \\ \text { Year } & \text { Employees } & \text { Spaces } & \text { Spaces } & \text { Parking Spaces } \\ 1999 & 1040 & 685 & 0 & 0 \\ 2000 & 1030 & 685 & 0 & 0 \\ 2001 & 1201 & 685 & 0 & 0 \\ 2004 & 1200 & 685 & \text { Leased Offsite Parking } \\ \text { Program } & \text { Leased Offsite } & \text { Leased Onsite Parking } & \text { Price (Space/Month) } \\ \text { Year } & \text { Parking Spaces } & \text { Price (Space/Month) } & \\ 1999 & 0 & & & \\ 2000 & 0 & & & \\ 2001 & 0 & & & \\ 2004 & 0 & & & \end{array}$

\section{Parking management}

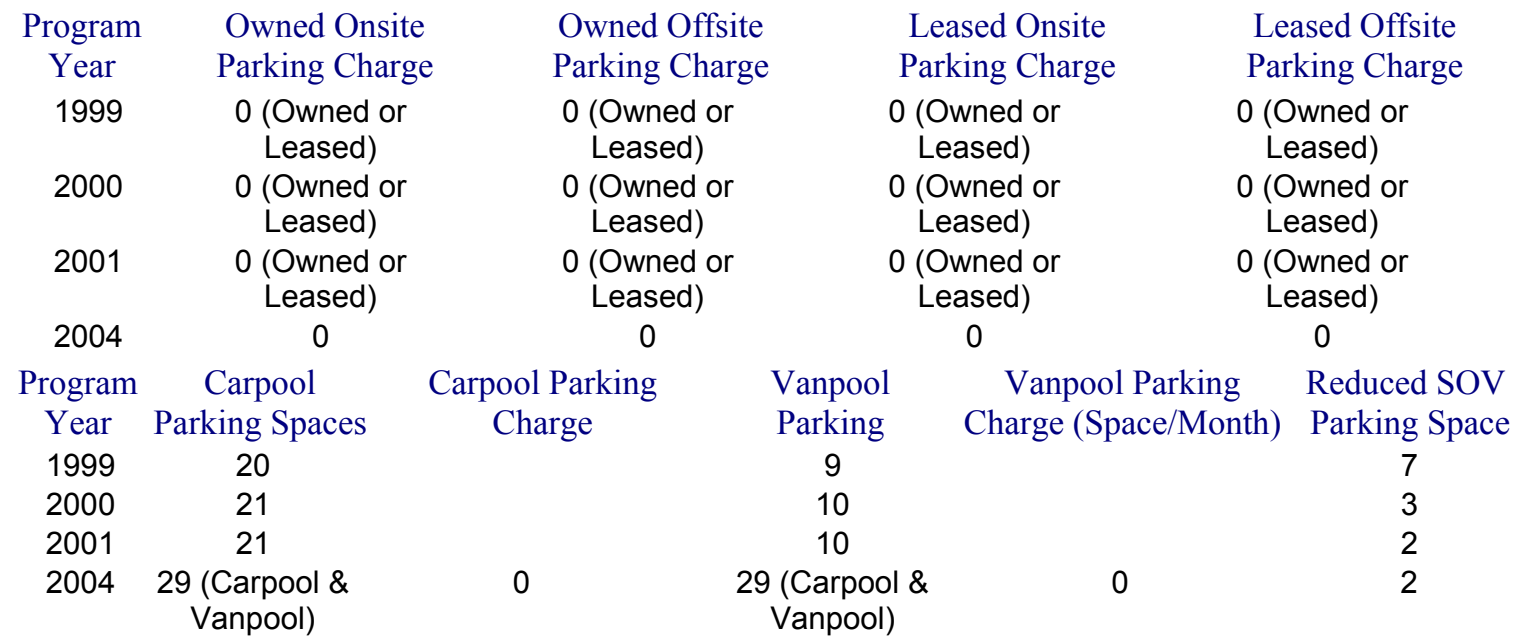

\section{Program Promotion}

\section{General (2004)}

Is the ETC's name, location and telephone number prominently displayed at this

Displayed where? The ETC's name, location and telephone number is displayed on the commuter option board in the Publi

Has the ETC completed a program developer/ETC training course?

On average, how many hours per week does the ETC spend on CTR activities?

Yes

5

Does the ETC have an active worksite committee to assist with the CTR

\section{Program promotion}

$\begin{array}{cc}\text { Program } & \text { Distribute } \\ \text { Year } & \text { Summary of CTR } \\ 1999 & \text { Yes } \\ 2000 & \text { Yes } \\ 2001 & \text { Yes } \\ 2004 & \text { Yes }\end{array}$

$\begin{array}{cc}\text { Post } & \text { Give Managers } \\ \text { Materials } & \text { Presentation } \\ \text { Yes } & \text { Yes } \\ \text { Yes } & \text { Yes } \\ \text { Yes } & \text { Yes } \\ \text { Yes } & \text { Yes }\end{array}$




$\begin{array}{cccccc}\begin{array}{c}\text { Program } \\ \text { Year }\end{array} & \begin{array}{c}\text { Give } \\ \text { Employees }\end{array} & \begin{array}{c}\text { Conduct } \\ \text { CTR Events }\end{array} & \begin{array}{c}\text { Publish } \\ \text { CTR Articles }\end{array} & \begin{array}{c}\text { Distribute } \\ \text { Information with }\end{array} & \begin{array}{c}\text { Distribute } \\ \text { Ridematch }\end{array} \\ 1999 & \text { Yes } & \text { Yes } & \text { Yes } & \text { No } & \text { Yes } \\ 2000 & \text { Yes } & \text { Yes } & \text { Yes } & \text { No } & \text { Yes } \\ 2001 & \text { Yes } & \text { Yes } & \text { Yes } & \text { No } & \text { Yes } \\ 2004 & \text { No } & \text { Yes } & \text { Yes } & \text { No } & \text { Yes }\end{array}$

\section{Site Amenities}

$\begin{array}{cccccc}\begin{array}{c}\text { Program } \\ \text { Year }\end{array} & \begin{array}{c}\text { Covered } \\ \text { Bicycle Spaces }\end{array} & \begin{array}{c}\text { Uncovered } \\ \text { Bicycle Spaces }\end{array} & \begin{array}{c}\text { Clothes } \\ \text { Lockers }\end{array} & \text { Showers } & \begin{array}{c}\text { Non-SOV On-site } \\ \text { Loading/Unloading } \\ \text { Shelters }\end{array} \\ 1999 & \text { Yes } & \text { Yes } & \text { Yes } & \text { Yes } & \text { No } \\ 2000 & \text { Yes } & \text { Yes } & \text { Yes } & \text { Yes } & \text { No } \\ 2001 & \text { Yes } & \text { Yes } & \text { Yes } & \text { Yes } & \text { No } \\ 2004 & \text { Yes } & \text { Yes } & \text { Yes } & \text { Yes } & \text { Nes }\end{array}$

Financial Subsidies, Incentives or Allowances

$\begin{array}{ccccc}\begin{array}{c}\text { Program } \\ \text { Year }\end{array} & \begin{array}{c}\text { Transit Subsidy } \\ \text { (Employee/Month) }\end{array} & \begin{array}{c}\text { Vanpool Subsidy } \\ \text { (Employee/Month) }\end{array} & \begin{array}{c}\text { Carpool Subsidy } \\ \text { (Employee/Month) }\end{array} & \begin{array}{c}\text { Walking Subsidy } \\ \text { (Employee/Month) }\end{array} \\ 2099 & \$ 34 & \$ 37 & 0 & 0 \\ 2000 & \$ 36 & & \$ 20 & 0 \\ 2004 & \$ 36 & \$ 65 & 0 & 0 \\ \text { Program } & \text { Ferry Subsidy } & \text { Bicycling Subsidy } & \text { Other Stipend } & \\ \text { Year } & \text { (Employee/Month) } & \text { (Employee/Month } & \text { (Employee/Month) } \\ 1999 & 0 & 0 & 0 & \\ 2000 & 0 & & 0 & \\ 2001 & 0 & 0 & 0 & \\ 2004 & 0 & 0 & 0\end{array}$

\section{Fleet Vehicles and Special Programs}

\section{Employer provided vehicles availability}

$\begin{array}{cccccc}\begin{array}{c}\text { Program } \\ \text { Year }\end{array} & \begin{array}{c}\text { FV Guaranteed } \\ \text { Ride Home }\end{array} & \text { FV Vanpool } & \begin{array}{c}\text { FV } \\ \text { Carpool }\end{array} & \begin{array}{c}\text { FV Work- } \\ \text { Related Trips }\end{array} & \begin{array}{c}\text { FV Non-Work } \\ \text { Related Errands }\end{array} \\ 1999 & \text { Yes } & \text { No } & \text { No } & \text { Yes } & \text { No } \\ 2000 & \text { Yes } & \text { No } & \text { No } & \text { Yes } & \text { No } \\ 2001 & \text { Yes } & \text { No } & \text { No } & \text { Yes } & \text { No } \\ 2004 & \text { Yes } & \text { No } & \text { No } & \text { Yes } & \text { No }\end{array}$

Other services availability

$\begin{array}{cccc}\text { Program } & \text { Employer-Provided } & \text { Guaranteed Ride Home } & \text { Internal Match } \\ \text { Year } & \text { Shuttle } & \text { Program } & \text { Program } \\ 1999 & \text { No } & \text { Yes } & \\ 2000 & \text { Yes } & \text { Yes } & \\ 2001 & \text { No } & \text { Yes } & \text { Yes } \\ 2004 & \text { No } & \text { Yes } & \end{array}$




\section{Mode Split and Vehicle Miles Traveled}

\begin{tabular}{|c|c|c|c|c|c|c|c|}
\hline $\begin{array}{l}\text { Program } \\
\text { Year }\end{array}$ & \multicolumn{2}{|c|}{$\begin{array}{l}\text { Num of Surveys } \\
\text { Distributed (Num of }\end{array}$} & \multicolumn{2}{|c|}{$\begin{array}{l}\text { Total Reported } \\
\text { Commuting Davs }\end{array}$} & $\begin{array}{c}\text { Driving } \\
\text { Alone }\end{array}$ & Carpooling & Vanpooling \\
\hline 1993 & & & 33 & & $83.5469 \%$ & $11.0283 \%$ & $0.0000 \%$ \\
\hline 1995 & & & 26 & & $76.0241 \%$ & $17.7753 \%$ & $1.5408 \%$ \\
\hline 1997 & & & 27 & & $78.0409 \%$ & $14.6394 \%$ & $3.8751 \%$ \\
\hline 1999 & & & 32 & & $73.7582 \%$ & $12.4649 \%$ & $5.9044 \%$ \\
\hline 2001 & & & 30 & & $69.4247 \%$ & $9.1467 \%$ & $13.0899 \%$ \\
\hline 2003 & & & 27 & & $66.6188 \%$ & $10.0611 \%$ & $14.3370 \%$ \\
\hline Program & Public & Bicycling & Walking & Other & & hicle Miles & \\
\hline Year & Transit & & & & & Traveled & \\
\hline 1993 & $1.3115 \%$ & $0.8942 \%$ & $1.4009 \%$ & 1.8182 & & 10.44 & \\
\hline 1995 & $2.5179 \%$ & $0.9395 \%$ & $0.8268 \%$ & 0.3758 & & 8.93 & \\
\hline 1997 & $1.5788 \%$ & $0.3588 \%$ & $0.7176 \%$ & 0.7894 & & 9.38 & \\
\hline 1999 & $5.1234 \%$ & $0.8122 \%$ & $1.0309 \%$ & 0.9060 & & 10.21 & \\
\hline 2001 & $6.5288 \%$ & $0.7757 \%$ & $0.8727 \%$ & 0.1616 & & 7.44 & \\
\hline 2003 & $7.5099 \%$ & $0.8983 \%$ & $0.3953 \%$ & 0.1797 & & 7.69 & \\
\hline
\end{tabular}

\section{Compressed Work Week, Flex Time and Teleworking}

\section{Policy (2001)}

Flex Time

There is no formal policy. It is the responsibility of the employee to work out a mutually agreeable schedule with his/her supervisor.

Teleworking

\section{Percentage of employees on Compressed Work}

\begin{tabular}{|c|c|c|c|c|c|}
\hline $\begin{array}{l}\text { Program } \\
\text { Year }\end{array}$ & $\begin{array}{c}\text { Num of Surveys } \\
\text { Distributed (Affected }\end{array}$ & $\begin{array}{l}\text { Total Surveys } \\
\text { Reported }\end{array}$ & \multicolumn{2}{|c|}{$\begin{array}{c}\text { Percentage of Employees } \\
\text { On } 5 \text { Days/Week }\end{array}$} & $\begin{array}{c}\text { Percentage of Employees } \\
\text { On } 3 \text { Days/Week }\end{array}$ \\
\hline 1993 & 1122 & 701 & \multicolumn{2}{|c|}{$85.5920 \%$} & $0.0000 \%$ \\
\hline 1995 & 871 & 552 & \multicolumn{2}{|c|}{$78.2609 \%$} & $0.0000 \%$ \\
\hline 1997 & 843 & 583 & \multicolumn{2}{|c|}{$77.8731 \%$} & $0.0000 \%$ \\
\hline 1999 & 1000 & 661 & \multicolumn{2}{|c|}{$84.7201 \%$} & $0.0000 \%$ \\
\hline 2001 & 1000 & 647 & \multicolumn{2}{|c|}{$84.5440 \%$} & $0.1546 \%$ \\
\hline 2003 & 1100 & 576 & \multicolumn{2}{|c|}{$91.4931 \%$} & $0.1736 \%$ \\
\hline Program & Percentage of Employees & \multirow{2}{*}{\multicolumn{2}{|c|}{$\begin{array}{c}\text { Percentage of Employees } \\
\text { On } 7 \text { Days/Two Weeks }\end{array}$}} & \multicolumn{2}{|c|}{ Percentage of Employees } \\
\hline Year & On 4 Days/Week & & & On $9 \mathrm{Da}$ & ys/Two Weeks \\
\hline 1993 & $3.8516 \%$ & \multicolumn{2}{|c|}{$0.4280 \%$} & \multicolumn{2}{|c|}{$8.1312 \%$} \\
\hline 1995 & $4.5290 \%$ & \multicolumn{2}{|c|}{$0.0000 \%$} & \multicolumn{2}{|c|}{$17.0290 \%$} \\
\hline 1997 & $4.1166 \%$ & \multicolumn{2}{|c|}{$0.1715 \%$} & \multicolumn{2}{|c|}{$15.9520 \%$} \\
\hline 1999 & $2.8744 \%$ & \multicolumn{2}{|c|}{$0.1513 \%$} & \multicolumn{2}{|c|}{$11.1952 \%$} \\
\hline 2001 & $4.1731 \%$ & \multicolumn{2}{|c|}{$0.1546 \%$} & \\
\hline 2003 & $2.2569 \%$ & \multicolumn{2}{|c|}{$0.1736 \%$} & \multicolumn{2}{|c|}{$10.3555 \%$} \\
\hline
\end{tabular}

\section{Percentage of employees on Telecommuting}

$\begin{array}{ccccc}\begin{array}{c}\text { Program } \\ \text { Year }\end{array} & \begin{array}{c}\text { Num of Surveys Distributed } \\ \text { (Num of Affected Employees) }\end{array} & \begin{array}{c}\text { Total Surveys } \\ \text { Reported }\end{array} & \begin{array}{c}\text { Total Percentage } \\ \text { of Telecommuters }\end{array} & \begin{array}{c}\text { 1 Days every } \\ \text { Two Weeks }\end{array} \\ 1993 & 1122 & 710 & 0.2817 \% & 0.0000 \% \\ 1995 & 871 & 554 & 0.7220 \% & 0.5415 \% \\ 1997 & 843 & 584 & 0.0000 \% & 0.0000 \% \\ 1999 & 1000 & 661 & 0.6051 \% & 0.1513 \% \\ 2001 & 1000 & 640 & 0.0000 \% & 0.0000 \% \\ 2003 & 1100 & 561 & 0.1783 \% & 0.0000 \%\end{array}$




$\begin{array}{cccccc}\begin{array}{c}\text { Program } \\ \text { Year }\end{array} & \begin{array}{c}\text { 2 Days every } \\ \text { Two Weeks }\end{array} & \begin{array}{c}\text { 3 Days } \\ \text { every Two }\end{array} & \begin{array}{c}\text { 4 Days every } \\ \text { Two Weeks }\end{array} & \begin{array}{c}\text { 5 Days every } \\ \text { Two Weeks }\end{array} & \begin{array}{c}\text { More than 5 } \\ \text { Days every Two } \\ 1993\end{array} \\ 0.1408 \% & 0.0000 \% & 0.0000 \% & 0.0000 \% & 0.1408 \% \\ 1995 & 0.0000 \% & 0.0000 \% & 0.0000 \% & 0.0000 \% & 0.1805 \% \\ 1997 & 0.0000 \% & 0.0000 \% & 0.0000 \% & 0.0000 \% & 0.0000 \% \\ 1999 & 0.0000 \% & 0.0000 \% & 0.3026 \% & 0.1513 \% & 0.0000 \% \\ 2001 & 0.0000 \% & 0.0000 \% & 0.0000 \% & 0.0000 \% & 0.0000 \% \\ 2003 & 0.0000 \% & 0.0000 \% & 0.1783 \% & 0.0000 \% & 0.0000 \%\end{array}$




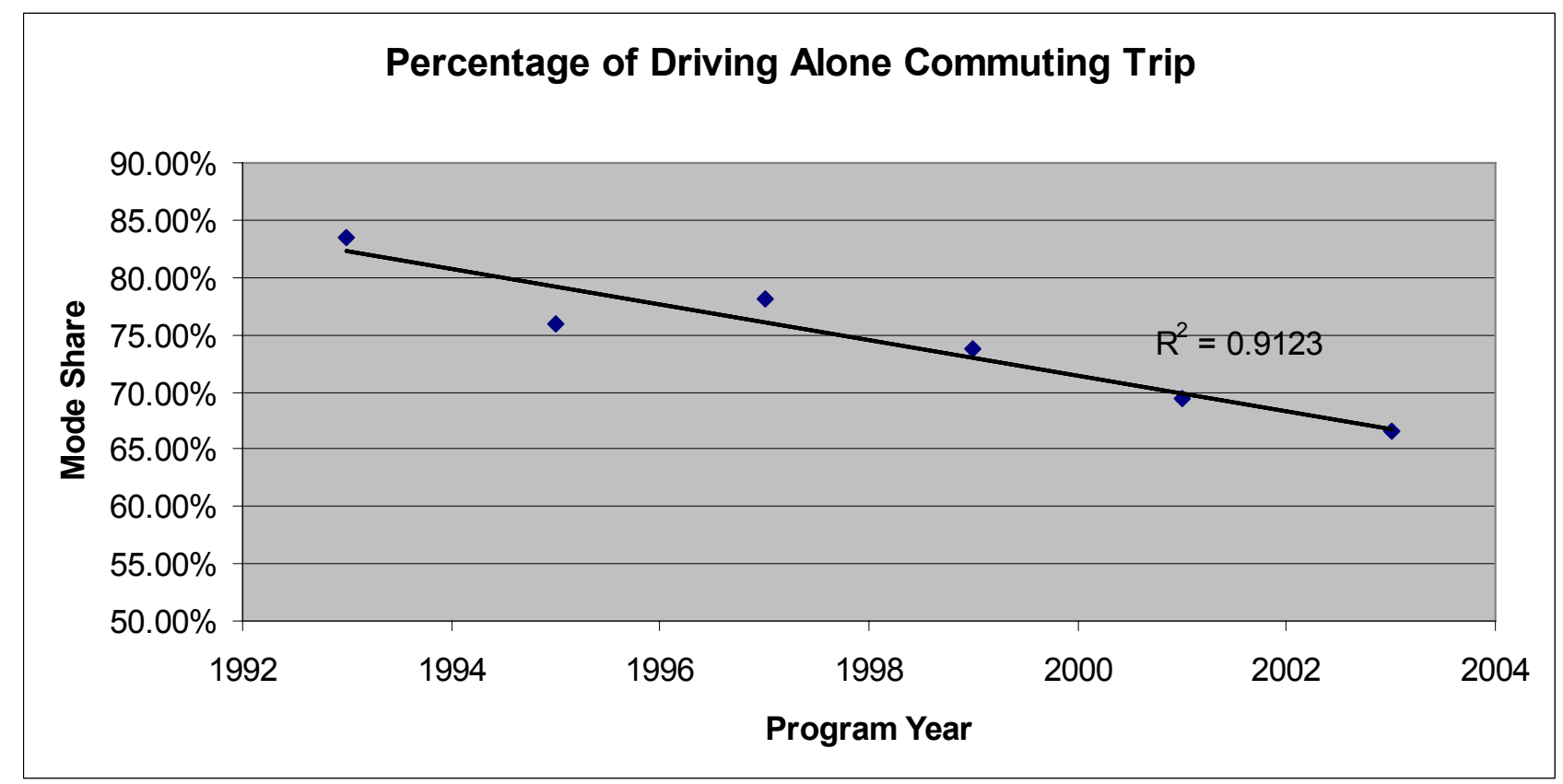

Figure 19: Percentage of Drive-Alone Commute Trips - Tacoma Public Utilities

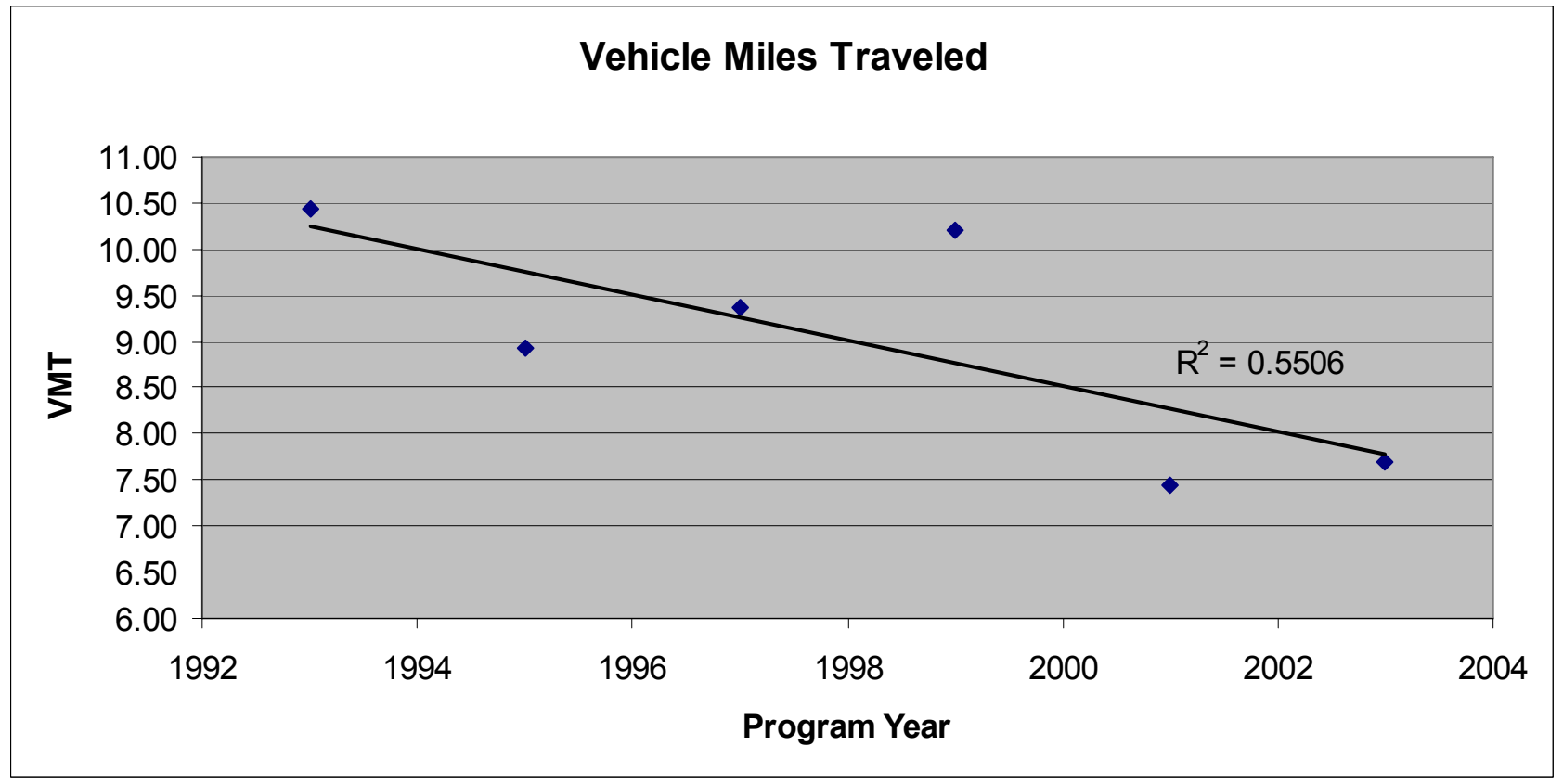

Figure 20: VMT - Tacoma Public Utilities 


\section{Virginia Mason Medical Center}

Seattle, WA

\section{Keys to Success}

Large employer, invests heavily in its CTR program, primarily with alternative transportation subsidies, limited parking, building space constraints, good transit service, strong neighborhood identity and active employer and community planning involvement, empowered ETC, lean production system.

\section{Results and Cost}

The main travel behavior change since the beginning of trip reduction activities has been a switch from single-occupant vehicle travel to transit. It appears that the hospital tried compressed work week but went back to a 5-day work week. Telecommuting has also increased. Between 1997 and 2003, vehicle miles traveled has decreased from an average of 6.9 miles for a one-way commute trip to 5.8 miles. During this same time period, the percentage mode split for drive alone travel has decreased from 40 percent to 30 percent.

The ETC says that most change in travel behavior is likely related to the combined ease of bus transportation and cost savings due to the subsidy and reduced car maintenance. Those who continue to drive alone do so for convenience; to come and go as they please and do it quickly.

The ETC did not have a precise figure for the total cost of the CTR program for Virginia Mason; however, he offered an estimate, which would include a 75 percent subsidy for alternative transportation modes for over 1,600 employees, as "... in the hundreds of thousands of dollars each year." A rough estimate based upon a 200326 percent drive alone rate means that approximately 1,184 persons used alternative modes. If everyone used the least expensive transportation subsidy $(\$ 41)$, this would amount to over $\$ 48,500$ per month in subsidies alone, or a total of over $\$ 582,500$ in subsidies per year.

\section{Organization Mission and Culture}

The worksite that was examined is the Virginia Mason Medical Center (hereinafter referred to as VMMC), a hospital located within a medical campus on the edge of the downtown core of Seattle, Washington. The worksite is located within its own building and also houses multiple employers that provide support services to the hospital. The hospital began in 1920 and always has been at its present location. VMMC is a private non-profit organization offering primary and specialty care clinics throughout the Puget Sound Region as well as a hospital in the downtown. To paraphrase the hospital's vision and mission, the hospital does not strive to be the biggest but instead the best, with an emphasis on quality care. Its mission is to provide a broad range of services to heal illness, prevent illness and improve one's sense of well-being. By law, the hospital worksite is required to participate in the Commute Trip Reduction (CTR) program. The ETC perceives that top management views trip reduction activities as aligned with the hospital business philosophy and management views trip reduction activities as resulting in business benefits to VMMC. The ETC's manager and his manager who is one of the hospital VPs both 


\section{Virginia Mason Medical Center}

\section{Seattle, WA}

have been at the hospital for 15 years and are aware of the history and understand that they need to participate and they also believe in it. The ETC's boss “....sticks his neck out for the program." The ETC said, "This is an incredible place to work and they (management) support us 100 percent. Their vision is to be the quality leader in the world and they want to serve the patient, customer and employee and part of that is commute trip reduction and they see that as vital and that helps us a lot."

Due to the nature of a hospital, the worksite is open 365 days per year, 24 hours per day and the worksite supports multiple shifts. There are difficulties with using TDM strategies in the nature of running a hospital because the hospital runs on different shifts. The nurses who work until 11 p.m. don't want to take transit because there are not enough routes running at night and they have to walk to the bus stop or make a transfer and they perceive it is dangerous.

VMMC also operates using the "Lean Production System" philosophy pioneered by Toyota. According to the ETC, it means trying to get the most out of existing resources "....and part of this is how we do our commuting and that helps us." The Lean Production System is a philosophy of running business that is complemented by the CTR program. The ten rules of lean production can be summarized:

\section{Eliminate waste}

2. Minimize inventory

3. Maximize flow

4. Pull production from customer demand

5. Meet customer requirements

6. Do it right the first time

7. Empower workers

8. Design for rapid changeover

9. Partner with suppliers

10. Create a culture of continuous improvement ${ }^{6}$

As an example of using the Lean Production System, hospital management believes the CTR program is more cost effective than providing parking and the subsidies are seen as having a positive return on employee satisfaction and how to make the hospital operate well.

VMMC also is actively involved in community planning. The surrounding First Hill neighborhood is an active participant in transportation issues, including a Planning Group and a Sound Transit Station Task Force. There was a proposal by local government to put transit service improvements on a ballot in 2007. The differing number of shifts at VMMC is a

\footnotetext{
${ }^{6}$ Also known as the Toyota Production System, developed by Engineer Ohno and summarized by Jim Malloy, 10/24/04
} 


\section{Virginia Mason Medical Center}

Seattle, WA

challenge. The hospital and several neighboring institutions on First Hill, including universities, had their CEOs write letters lobbying City Council for connecting routes to the train station, service to outlying areas and service for non-peak hours, such as early mornings, nights, and weekends. There are many people who have been working on transportation issues for more than ten years and they all know each other. They organize, share information, and have frequent meetings to put their forces together. A Metro representative leads these meetings. Officially it is a requirement to go to these meetings but according to the ETC, it has become more than that.

Sound Transit is considering building a light rail system with a station in First Hill and there is discussion between VMMC and some of the other medical centers and universities. VMMC does not feel it is being served well so there is disagreement over the funds for light rail and where the rail line will go. There is a lack of consensus among First Hill community activists with regard to particular improvements for light rail service. There is also congestion on one of the main streets running through First Hill so there is discussion among VMMC and its neighbors regarding what to do.

\section{External Conditions}

On a scale from " 1 " to " 10 ", "1" being free flow and " 10 " being gridlock, traffic conditions during peak hours are perceived by the ETC as a " 6 " and the level of traffic congestion has stayed about the same over the past year. The road system surrounding the worksite is described as a dense grid of streets and major highways. Bus service arrives every 5-10 minutes during peak hours of commuting. Sound Transit serves the hospital as well as King County Metro. The ETC perceives bus service as good but there are gaps in service. Within one block there are restaurants, drug stores and a bank, and sidewalks on-site, bike lanes, near-site child care and shopping within one quarter mile.

The changing economy has required the hospital to cut spending so the hospital cannot expand presently. The trip reduction program enables the medical center to concentrate more of its resources toward providing client services rather than expanding parking. Patients frequently take transit too, so there are benefits in supporting transit to make sure the patients can get to the hospital too. Many customers come from the suburbs and so it is also necessary to free up parking for patients.

\section{On-Site Facilities}

The ETC said there is not enough space for more parking within VMMC and some parking is old. Site amenities include both covered and uncovered bicycle parking, clothes lockers and showers and non-SOV on-site loading shelters.

\section{Employee Characteristics}

Approximately 75 percent of employees are full-time and the other 25 percent are part-time. There is no temporary staff. Medical personnel generally eat meals on-site. Most employees do 


\section{Virginia Mason Medical Center}

\section{Seattle, WA}

not live near the hospital but out of the city. If errands are run during the trip homeward, personal business destinations are generally closer to the home end than to the worksite. The employees are a diverse group by profession, skill level and pay, including clerical and administrative, laboratory, medical and service. As a result, work dress includes business casual, casual and uniform.

The ETC says that the one example of marketing particular transportation services to a particular job type or employee cohort are reserved parking spaces for doctors. With regard to employee receptivity to commute alternatives by job type, most doctors will drive alone and use the reserved parking spaces but a few doctors will bicycle and ask about transit. Many nurses take transit, but some high-priced outside parking lots also are used by some nurses. Many people in administration and the majority of clerical, maintenance and service workers will take buses and the train.

Some employees have volunteered for vanpools and vanshares. Vanshares are connecting vans. While a vanpool goes home with the driver and he or she then picks up the riders the next morning, a vanshare is just between two locations so it parks at the hospital in the morning and then goes to the train station at night and stays there overnight. Employees were needed to organize it and take charge of it and several stepped forward. Employees have come forward and set vanshares up themselves if the ETC cannot do it. And they have attracted other employees to help out.

Ferry riders typically live farther away from Seattle "across the water". Some of the ferry riders fit in the category of 'champions' who are enthusiastic about their commute mode and inspire others to try it. There are not as many of them. Commuting by ferry is expensive. They gather together and they lobby.

\section{Commute Trip Reduction Program}

There are approximately 500 parking spaces compared to over 1,600 CTR-affected employees at the downtown hospital worksite. There is also public parking within one quarter mile of the worksite that costs $\$ 3$ per hour and $\$ 12$ maximum per day. The price for parking increased 75 percent between 2003 and 2004. The worksite leases both on-site and off-site parking for $\$ 185$ per space per month and charges this same amount per employee. The program now offers discounted parking for employees arriving between 2:45 and 3:45 p.m. About one third of the 500 spaces are reserved for doctors. Carpool parking is $\$ 40$ per month and vanpool parking is free. The program recently stepped up its enforcement of reserved parking for carpools. According to the ETC, VMMC is committed to the whole concept of managing people's commuting and travel. For example, the hospital is building a new wing but they are not building additional parking for it.

Staff that is eligible for benefits receives 75 percent of the price of a monthly or annual bus pass from Virginia Mason. The program includes monthly subsidies for transit (\$41), vanpools $(\$ 60)$, carpools $(\$ 41)$ and ferry $(\$ 75)$, an employer-provided shuttle, guaranteed ride home and an 


\section{Virginia Mason Medical Center}

Seattle, WA

internal ridematching program. Non-eligible staff may purchase discount bus tickets. Staff who are eligible for benefits and work more than 20 hours per week can open a Transportation Fringe Benefit Account that allows pre-tax savings for out-of-pocket transit expenses.

Promotional activities include spring and fall events, orientation for new employees, presentations to managers, and intranet highlights for employee awareness. Information is provided in the hospital directory, hospital publications, and a commute information board.

When asked how the program has evolved since the ETC started in his position, he said the adoption of the Intranet has had a huge impact and everything has moved more to computer use which has made administration of the CTR program easier. Nine months ago, Virginia Mason started a Flexcar program, which has widespread use in Seattle. The hospital pays Flexcar a flat fee for a Honda Element, which is available for free to employees for both departmental and personal use. The ETC says the service is not as well used as he expected but he believes this is partly due to a lack of PR and word of mouth.

\section{Employee Transportation Coordinator}

The Employee Transportation Coordinator (ETC) interviewed is the Senior Operations Manager of Parking and Commuter Services within the Security Department, who has served in the capacity of ETC for two and a half years. Employees know him as the Parking and Commuter Services Manager. The ETC has a separate office located by one of the main entrances. His ETC duties are explicitly listed as part of his written job description and he spends 20 hours per week on ETC duties. He was assigned the job of ETC. The ETC has an active worksite committee that assists with the CTR program.

The ETC has actively connected with outside sources of support for the trip reduction program, including a TMA, an ETC network, a regional commuter assistance program and the collaboration of other worksites.

The ETC expressed that it felt unusual to be in charge not only of all parking but also of all commuting services as well. One would assume these two areas would be at odds. The ETC has to encourage parking because the hospital gets revenue from that. But the ETC also must discourage parking and encourage commute alternatives. The hospital has five parking garages and 6 outside lots. The money from the garage goes to maintenance, labor as well as helping to run the hospital. The job of the ETC is to find the right balance of providing parking to those who need it and then the revenue goes toward running the hospital and enabling other people to use alternative modes.

The ETC distributes a printed brochure to employees about the CTR program but VMMC has an intranet bulletin board that is commonly read by employees. It has limited space and many departments seek permission to use that space for announcements. The ETC sees the need to do more public relations for the CTR program but it is a struggle with the Communications Department at VMMC. The ETC makes many submissions of what he wants to post on the intranet bulletin board but the person in charge of the board has control over what and when information is publicized on the board. 


\section{Virginia Mason Medical Center}

\section{Seattle, WA}

The ETC said that the disadvantage of his position is that he has many duties overseeing all the garages and parking lots and this takes more than half his time and he would rather spend at least half his time doing commute work. Commute work is supposed to be just as big a part of his job. Aside from difficulties with getting PR messages out on the intranet, the ETC can do pretty much anything he wants as long as he consults with his supervisor. The more ideas he has and the more he wants to do, there is no fear that management will say no; they are going to help him. The ETC has been in his job for two and half years and he knows people now so it is easier to get the word out and people will help him.

The ETC reports to one manager at the hospital but he is actually employed by a different company he is a contracted employee so he has his own company from outside of the hospital but his boss outside the hospital is not involved with the specific tasks of the ETC's job.

Personally, the ETC has always loved mass transit and commuting by bus so he likes what he does but also he says " ...it is a great thing because there are so many people - say we have 5,000 employees and it seems like there are at least 3,000 employees with not a lot of money who depend on the bus and they are always thanking me. I'm always able to help them find routes and different options, so it's just a good thing and I get a lot of satisfaction out of that."

The ETC says that he hears much conversation about commute travel issues. People are always stopping by his office. There is a large ferry system and the ferry riders are very vocal and will lobby for what they need. Some routes not serviced well. Some people come in for help finding a route or will tell him where all the connecting routes are. Some come in to complain. The ETC gets "tons of emails" on the intranet. The ETC is excited about his work. He gets a sense of accomplishment from it. He knows he is helping others. There is still more to be done, which keeps it interesting. To some degree he has limited power and must work within the confines of other departments, but he gets good management support and can run with his own ideas. He implements the balancing between encouraging parking and discouraging parking. Management appreciates that balancing act. Parking revenues go into the operation of the hospital. A new wing will not have any new parking added. 


\section{Organization Information (2004) \\ Virginia Mason Medical Center}

Seattle, WA

Website:

www.vmmc.org

Primary Business:

Non-profit organization?

Health Care

No

390

390

Affected Employees:

Is the CTR program subject to collective bargaining? No

Does this worksite have multiple shifts?

Yes

Shifts description:

Due to the nature of our establishment, we are open 24 hours a day, 7 days a week and 365 days a year.

\section{CTR program contact:}

David Lantry

King County Metro

400 Yesler Way, MS YES-TR-0650, Seattle, WA 98104

Phone: (206) 684-1139

Email: david.lantry@metrokc.gov

\section{Worksite Characteristics (2004)}

$\begin{array}{cccccc}\text { Bus stop(s) } & \text { Bike lane } & \text { Sidewalks } & \text { Restaurants } & \text { Shopping } & \text { Bank } \\ \text { Availability } & \text { Availability } & \text { Availability } & \text { Availability } & \text { Availability } & \text { Availability } \\ \text { Onsite } & \text { Within 1/4 mile } & \text { Onsite } & \text { Onsite } & \text { Within 1/4 mile } & \text { Onsite }\end{array}$

\section{Program Narrative (1999)}

Participate in Spring and Fall promo activities, i.e. Relax, WSRO Rideshare week, orientation for new employees, Guaranteed Ride Home Program, Member of first Hill Planning group, participate in 1st Hill neighborhood activities, member of Sound Transit 1st Hill Station Task Force, Intranet highlights for employee awareness.

\section{Worksite Parking and Parking Management Information}

\section{Parking management and monitoring (2004)}

All parking privileges must go through the Transportation/Parking office; this office verifies availability and eligibility.

\section{Parking}

Program

Year

1999

2002

2003

2004

Program

Total Num of

Employees

598

394

394

390

Onsite Parking
Spaces

59

200

200

200

Leased Offsite

Parking Spaces

95

0
Leased Onsite Parking

Price (Space/Month)

$\$ 75$

$\$ 97.55$

$\$ 100$

$\$ 175$
Offsite Parking Spaces

95

0
Leased Onsite

Parking Spaces 59

153

153

120

Leased Offsite Parking

Price (Space/Month) $\$ 62$

$\$ 97.55$

$\$ 100$

$\$ 175$ 


\section{Parking management}

\begin{tabular}{|c|c|c|c|c|c|}
\hline \multirow{2}{*}{$\begin{array}{l}\text { Program } \\
\text { Year }\end{array}$} & Owned Onsite & \multicolumn{2}{|c|}{ Owned Offsite } & Leased Onsite & Leased Offsite \\
\hline & Parking Cha & Parking & & king Charge & king Charge \\
\hline 1999 & & & & & \\
\hline 2002 & & & & $\$ 105$ & \\
\hline 2003 & 0 & 0 & & $\$ 110$ & 0 \\
\hline 2004 & & & & $\$ 175$ & \\
\hline Program & Carpool & Carpool Parking & Vanpool & Vanpool Parking & Reduced SOV \\
\hline Year & Parking Spaces & Charge & Parking & Charge (Space/Month) & Parking Space \\
\hline 1999 & 6 & $\$ 50$ & 0 & & 22 \\
\hline 2002 & $\begin{array}{c}19 \text { (Carpool \& } \\
\text { Vanpool) }\end{array}$ & $\$ 30$ & $\begin{array}{c}19 \text { (Carpool \& } \\
\text { Vanpool) }\end{array}$ & & 0 \\
\hline 2003 & $\begin{array}{c}31 \text { (Carpool \& } \\
\text { Vanpool) }\end{array}$ & $\$ 30$ & $\begin{array}{c}31 \text { (Carpool \& } \\
\text { Vanpool) }\end{array}$ & 0 & 6 \\
\hline 2004 & $\begin{array}{c}31 \text { (Carpool \& } \\
\text { Vanpool) }\end{array}$ & $\$ 40$ & $\begin{array}{c}31 \text { (Carpool \& } \\
\text { Vanpool) }\end{array}$ & & 0 \\
\hline
\end{tabular}

\section{Program Promotion}

General (2004)

Is the ETC's name, location and telephone number prominently displayed at this

Yes

Displayed where? The information is available at the commute info. board, intranet, hospital directory, and all publi

Has the ETC completed a program developer/ETC training course?

No

On average, how many hours per week does the ETC spend on CTR activities? 20

Does the ETC have an active worksite committee to assist with the CTR Yes

\section{Program promotion}

\begin{tabular}{|c|c|c|c|c|c|c|}
\hline $\begin{array}{l}\text { Program } \\
\text { Year }\end{array}$ & $\begin{array}{c}\text { Distribute } \\
\text { Summary of CTR }\end{array}$ & \multicolumn{3}{|c|}{$\begin{array}{l}\text { Provide CTR Program } \\
\text { Information to New Employees }\end{array}$} & $\begin{array}{c}\text { Post } \\
\text { Materials }\end{array}$ & $\begin{array}{c}\text { Give Managers } \\
\text { Presentation }\end{array}$ \\
\hline 1999 & Yes & & Yes & & Yes & Yes \\
\hline 2002 & Yes & & Yes & & Yes & Yes \\
\hline 2003 & Yes & & Yes & & Yes & Yes \\
\hline 2004 & Yes & & Yes & & Yes & Yes \\
\hline Program & Give & Conduct & Publish & Dist & oute & Distribute \\
\hline Year & Employees & TR Events & CTR Articles & Inform & on with & Ridematch \\
\hline 1999 & Yes & Yes & Yes & $\mathrm{N}$ & & Yes \\
\hline 2002 & Yes & Yes & Yes & $\mathrm{N}$ & & Yes \\
\hline 2003 & Yes & Yes & Yes & $\mathrm{N}$ & & Yes \\
\hline 2004 & Yes & Yes & Yes & $\mathrm{N}$ & & Yes \\
\hline
\end{tabular}

\section{Site Amenities}

$\begin{array}{cccccc}\begin{array}{c}\text { Program } \\ \text { Year }\end{array} & \begin{array}{c}\text { Covered } \\ \text { Bicycle Spaces }\end{array} & \begin{array}{c}\text { Uncovered } \\ \text { Bicycle Spaces }\end{array} & \begin{array}{c}\text { Clothes } \\ \text { Lockers }\end{array} & \text { Showers } & \begin{array}{c}\text { Non-SOV On-site } \\ \text { Loading/Unloading Shelters }\end{array} \\ 1999 & \text { Yes } & \text { Yes } & \text { No } & \text { No } & \text { Yes } \\ 2002 & \text { Yes } & \text { Yes } & \text { Yes } & \text { Yes } & \text { Yes } \\ 2003 & \text { Yes } & \text { Yes } & \text { Yes } & \text { Yes } & \text { Yes } \\ 2004 & \text { Yes } & \text { Yes } & \text { Yes } & \text { Yes } & \text { Yes }\end{array}$




\begin{tabular}{ccccc}
\multicolumn{5}{c}{ Financial Subsidies, Incentives or Allowances } \\
$\begin{array}{c}\text { Program } \\
\text { Year }\end{array}$ & $\begin{array}{c}\text { Transit Subsidy } \\
\text { (Employee/Month) }\end{array}$ & $\begin{array}{c}\text { Vanpool Subsidy } \\
\text { (Employee/Month) }\end{array}$ & $\begin{array}{c}\text { Carpool Subsidy } \\
(\text { Employee/Month) }\end{array}$ & $\begin{array}{c}\text { Walking Subsidy } \\
\text { (Employee/Month) }\end{array}$ \\
1999 & $\$ 75 \%$ of Appln Pass & $75 \%$ subsidy & & 0 \\
2002 & & & 0 & 0 \\
2003 & $\$ 41$ & $\$ 60$ & 0 & 0 \\
2004 & $\$ 41$ & $\$ 60$ & $\$ 41$ & 0 \\
Program & Ferry Subsidy & Bicycling Subsidy & Other Stipend & \\
Year & (Employee/Month) & (Employee/Month & (Employee/Month) \\
1999 & $75 \%$ subsidy & 0 & 0 & \\
2002 & & 0 & 0 & \\
2003 & $\$ 75$ & 0 & 0 & \\
2004 & $\$ 75$ & 0 & & 0
\end{tabular}

\section{Fleet Vehicles and Special Programs}

\section{Employer provided vehicles availability}

\begin{tabular}{|c|c|c|c|c|c|}
\hline $\begin{array}{l}\text { Program } \\
\text { Year }\end{array}$ & $\begin{array}{l}\text { FV Guaranteed } \\
\text { Ride Home }\end{array}$ & FV Vanpool & $\begin{array}{c}\mathrm{FV} \\
\text { Carpool }\end{array}$ & $\begin{array}{l}\text { FV Work- } \\
\text { Related Trips }\end{array}$ & $\begin{array}{l}\text { FV Non-Work } \\
\text { Related Errands }\end{array}$ \\
\hline 1999 & No & No & No & Yes & No \\
\hline 2002 & No & No & No & Yes & Yes \\
\hline 2003 & No & No & No & Yes & Yes \\
\hline 2004 & No & No & No & Yes & Yes \\
\hline
\end{tabular}

Other services availability

$\begin{array}{cccc}\begin{array}{c}\text { Program } \\ \text { Year }\end{array} & \begin{array}{c}\text { Employer-Provided } \\ \text { Shuttle }\end{array} & \begin{array}{c}\text { Guaranteed Ride Home } \\ \text { Program }\end{array} & \begin{array}{c}\text { Internal Match } \\ \text { Program }\end{array} \\ 1999 & \text { Yes } & \text { Yes } & \\ 2002 & \text { Yes } & \text { Yes } & \text { Yes } \\ 2003 & \text { Yes } & \text { Yes } & \text { Yes } \\ 2004 & \text { Yes } & \text { Yes } & \text { Yes }\end{array}$

\section{Mode Split and Vehicle Miles Traveled}

\begin{tabular}{|c|c|c|c|c|c|c|c|}
\hline Program & \multicolumn{2}{|c|}{ Num of Surveys } & \multicolumn{2}{|c|}{ Total Reported } & Driving & \multirow[t]{2}{*}{ Carpooling } & \multirow[t]{2}{*}{ Vanpooling } \\
\hline Year & Distribut & Num of & Commutil & Days & Alone & & \\
\hline 1997 & \multicolumn{2}{|c|}{366} & \multicolumn{2}{|c|}{1276} & $39.9687 \%$ & $14.3417 \%$ & $0.0000 \%$ \\
\hline 1999 & \multicolumn{2}{|c|}{457} & \multicolumn{2}{|c|}{1803} & $31.1148 \%$ & $14.0876 \%$ & $0.2773 \%$ \\
\hline 2001 & \multicolumn{2}{|c|}{469} & \multicolumn{2}{|c|}{1138} & $24.8682 \%$ & $18.2777 \%$ & $5.9754 \%$ \\
\hline 2003 & \multicolumn{2}{|c|}{443} & 179 & & $30.0391 \%$ & $13.0095 \%$ & $1.0609 \%$ \\
\hline Program & Public & Bicycling & Walking & Othe & \multicolumn{2}{|c|}{ Vehicle Miles } & \\
\hline Year & Transit & & & & \multicolumn{2}{|c|}{ Traveled } & \\
\hline 1997 & $38.3229 \%$ & $0.6270 \%$ & $6.0345 \%$ & 0.705 & \multicolumn{2}{|c|}{6.84} & \\
\hline 1999 & $47.3100 \%$ & $0.2773 \%$ & $5.6018 \%$ & 1.331 & \multicolumn{2}{|r|}{6.00} & \\
\hline 2001 & $47.0123 \%$ & $0.3515 \%$ & $0.7030 \%$ & 2.812 & & 6.30 & \\
\hline 2003 & $46.4545 \%$ & $0.4467 \%$ & $5.8068 \%$ & 3.182 & & 5.66 & \\
\hline
\end{tabular}




\section{Compressed Work Week, Flex Time and Teleworking}

\section{Policy (1999)}

Flex Time

Teleworking If feasible, department assigned telework status, i.e., transcriptionists, schedulers, patient services.

\section{Percentage of employees on Compressed Work}

\begin{tabular}{|c|c|c|c|c|c|}
\hline Program & Num of Surveys & Total Surveys & \multicolumn{2}{|c|}{ Percentage of Employees } & Percentage of Employees \\
\hline Year & Distributed (Affected & Reported & \multicolumn{2}{|c|}{ On 5 Days/Week } & On 3 Days/Week \\
\hline 1997 & 366 & 267 & \multicolumn{2}{|c|}{$89.5131 \%$} & $0.3745 \%$ \\
\hline 1999 & 457 & 374 & \multicolumn{2}{|c|}{$86.8984 \%$} & $0.2674 \%$ \\
\hline 2001 & 469 & 244 & \multicolumn{2}{|c|}{$88.5246 \%$} & $0.0000 \%$ \\
\hline 2003 & 443 & 379 & \multicolumn{2}{|c|}{$91.8206 \%$} & $0.2639 \%$ \\
\hline Program & Percentage of Employees & \multirow{2}{*}{\multicolumn{2}{|c|}{$\begin{array}{l}\text { Percentage of Employees } \\
\text { On } 7 \text { Days/Two Weeks }\end{array}$}} & \multirow{2}{*}{\multicolumn{2}{|c|}{ Percentage of Employees }} \\
\hline Year & On 4 Days/Week & & & & \\
\hline 1997 & $5.2434 \%$ & \multicolumn{2}{|c|}{$0.0000 \%$} & \multicolumn{2}{|c|}{$4.4944 \%$} \\
\hline 1999 & $5.8824 \%$ & \multicolumn{2}{|c|}{$0.0000 \%$} & \multicolumn{2}{|c|}{$6.4171 \%$} \\
\hline 2001 & $7.3770 \%$ & \multicolumn{2}{|c|}{$1.2295 \%$} & \\
\hline 2003 & $31662 \%$ & \multicolumn{2}{|c|}{$00000 \%$} & \multicolumn{2}{|c|}{$0.8197 \%$} \\
\hline
\end{tabular}

\section{Percentage of employees on Telecommuting}

\begin{tabular}{|c|c|c|c|c|c|}
\hline $\begin{array}{l}\text { Program } \\
\text { Year }\end{array}$ & \multicolumn{2}{|c|}{$\begin{array}{l}\text { Num of Surveys Distributed } \\
\text { (Num of Affected Employees) }\end{array}$} & $\begin{array}{c}\text { Total Surveys } \\
\text { Reported }\end{array}$ & $\begin{array}{l}\text { Total Percentage } \\
\text { of Telecommuters }\end{array}$ & $\begin{array}{l}1 \text { Days every } \\
\text { Two Weeks }\end{array}$ \\
\hline 1997 & \multicolumn{2}{|c|}{366} & 269 & $1.8587 \%$ & $0.7435 \%$ \\
\hline 1999 & \multicolumn{2}{|c|}{457} & 366 & $3.8251 \%$ & $1.9126 \%$ \\
\hline 2001 & \multicolumn{2}{|c|}{469} & 241 & $1.6598 \%$ & $0.8299 \%$ \\
\hline 2003 & \multicolumn{2}{|c|}{443} & 367 & $6.8120 \%$ & $1.9074 \%$ \\
\hline Program & 2 Days every & 3 Days & 4 Days every & 5 Days every & More than 5 \\
\hline Year & Two Weeks & every Two & Two Weeks & Two Weeks & Days every Two \\
\hline 1997 & $0.3717 \%$ & $0.3717 \%$ & $0.0000 \%$ & $0.0000 \%$ & $0.3717 \%$ \\
\hline 1999 & $1.6393 \%$ & $0.0000 \%$ & $0.0000 \%$ & $0.2732 \%$ & $0.0000 \%$ \\
\hline 2001 & $0.4149 \%$ & $0.0000 \%$ & $0.0000 \%$ & $0.0000 \%$ & $0.4149 \%$ \\
\hline 2003 & $1.3624 \%$ & $0.2725 \%$ & $1.0899 \%$ & $0.0000 \%$ & $2.1798 \%$ \\
\hline
\end{tabular}




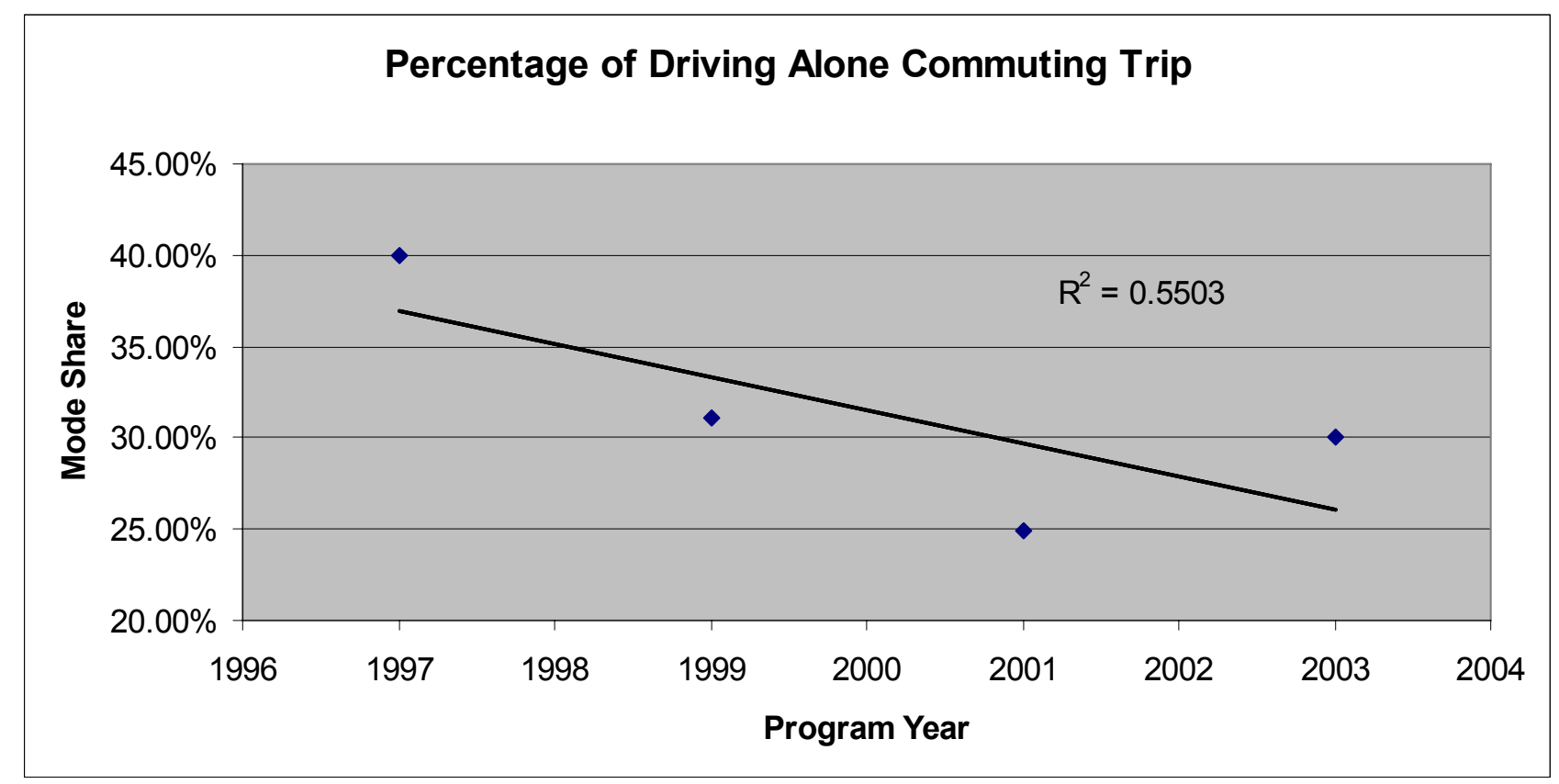

Figure 21: Percentage of Drive-Alone Commute Trips - Virginia Mason Medical Ctr.

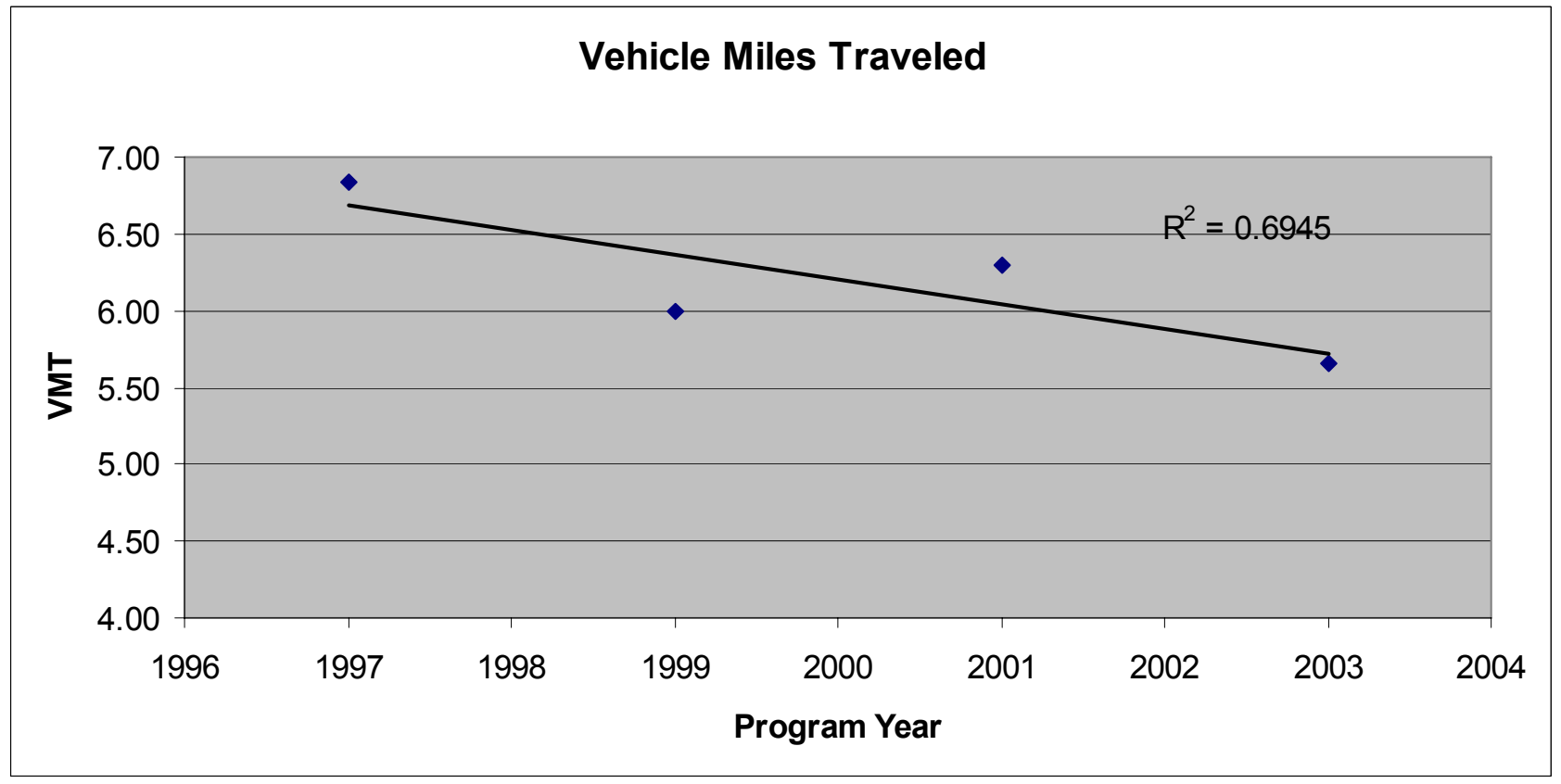

Figure 22: VMT - Virginia Mason Medical Ctr. 


\section{Weyerhaeuser Company}

Puget Sound Area

Federal Way, Washington

\section{Keys to Success}

The Weyerhaeuser Company is a type of business that must comply with various environmental regulations in addition to the Washington State Commute Trip Reduction (CTR) Law. Weyerhaeuser is motivated to minimize operations costs through sustainable practices and to demonstrate good corporate citizenship to both the general public and to its shareholders. Weyerhaeuser is a large and profitable business that provides abundant staff resources and capital to run its Commute Trip Reduction Program, called the Weyerhaeuser Freeways Program. This program provides a multitude of commute options, subsidies and support services to appeal to diverse travel needs and preferences. While the company is not located in a downtown where transit can provide strong service, Weyerhaeuser builds upon existing regional transit service by operating a shuttle. However, vanpooling and carpooling are the alternative modes of choice by employees. Because the company is large and participates in networking with other area employers, it is not difficult for a Weyerhaeuser employee to find another person whose work hours and geographic location are similar. Weyerhaeuser employs a full-time employee transportation coordinator who manages a crew and is empowered to develop and run the program. Surrounding traffic congestion is worse than average and the labor shed is regional in size, in which some employees travel very long distances. The primary motivator for alternative mode users is cost savings rather than time savings.

\section{Results and Cost}

Despite that employee parking is free and plentiful, with 822 parking spaces owned onsite, the drive alone rate decreased between 1993 and 2003 from 85 percent to 66 percent. During that time, carpooling increased from 8 percent to almost 17 percent, and vanpooling increased from 4.5 percent to over 14 percent. The remaining three percent of employees use public transit, bicycle, or walk to work. The average one way VMT per employee decreased between 1993 and 2003 from 13.6 VMT to 11.8 VMT. Within that same time period, SOV travel decreased from 85 percent to 66 percent.

The CTR program has been well supported by sufficient staff and capital resources. The ETC estimated last year's annual cost of the CTR program in the neighborhood of $\$ 450,000$, which includes labor, services and incentives, subsidies and promotions, and an internal shuttle.

\section{Organization Mission}

The Weyerhaeuser Company is ranked $90^{\text {th }}$ in FORTUNE Magazine's largest U.S. corporations in 2006. The written mission of the Weyerhaeuser Company is to "Produce superior returns for our shareholders by focusing on our customers and safely growing and harvesting trees, manufacturing and selling forest products, and building and selling homes." Weyerhaeuser operates mills and other facilities at sites across the United States and in 18 other countries. In 


\section{Weyerhaeuser Company}

\section{Puget Sound Area}

\section{Federal Way, Washington}

Weyerhaeuser's "Our Roadmap for Success", explicitly recognized values include being an "employer of choice, treating people with respect and providing a safe and healthy workplace." Values also include "support for [host] communities, demonstrating highest standards of ethical conduct, environmental responsibility and open communications".

This is an industry that generates stationary source air emissions and other hazardous waste byproducts. It is regulated by the U.S. Environmental Protection Agency. Weyerhaeuser's financial and environmental sustainability emphasis is focused mostly upon its primary industrial energy consumption as detailed in their most recent 80-page report, "Forests Sustain Lives, Weyerhaeuser Company 2005 Sustainability Report". Interestingly, Weyerhaeuser uses mobile source emissions indicators as a yardstick for its success, as summarized in a June 21, 2006 press release: "In what amounts to a win-win for shareholders and the environment, Weyerhaeuser today pledged to reduce greenhouse gas emissions 40 percent by 2020 while reducing its reliance on high-priced fossil fuels. A 40 percent reduction in annual greenhouse gases is the equivalent of taking 700,000 vehicles off the road for one year. 'We will do this by harnessing the benefits of a renewable, natural resource - biomass - as fuel in the boilers that generate steam and electrical energy in our mills,' said Ernesta Ballard, senior vice president, Corporate Affairs." Nonetheless, Weyerhaeuser also recognizes that the commute trip reduction program is part of the overall company sustainability effort, as was summarized in one paragraph of the 2005 Sustainability Report: "Headquarters employees reduce dependence on cars. Weyerhaeuser employees are encouraged to be responsible environmental stewards in their everyday actions. More than half of the corporate headquarters staff is enrolled in the Weyerhaeuser Freeways program...In 2005, this program reduced the total vehicle miles driven to and from work by 1.3 million, which reduced pollutants by more than 74,000 pounds." (2005 Sustainability Report, p. 54)

The Weyerhaeuser Freeways Program has its own mission statement: "To develop and manage an effective employee transportation program that meets business needs, regulatory requirements and enhances the reputation of the company. The program is designed to provide opportunities for all employees to use alternative modes of transportation to improve regional mobility and quality of life." Weyerhaeuser is highly motivated to practice good corporate citizenship.

\section{Employee Characteristics}

The ETC explained that it is an ongoing effort to run the CTR program. While new employees get a packet of information about all the services offered, longstanding employees need to be reminded on a continual basis that transportation options are available. The biggest hurdle is convincing employees to try alternative modes. After a first successful experience, alternative modes sell themselves in addition to positive word-of-mouth. Successful commuter services are those that employees want to continue using. Alternative modes must be simple, easy, and comfortable for employees.

The Weyerhaeuser worksite observed for this case study provides the administrative and 


\section{Weyerhaeuser Company}

\section{Puget Sound Area}

Federal Way, Washington

professional support for the development of lumber products at associated mills. The ETC describes the work force as high-paid white collar professionals representing a wide range of job types. Approximately 75 percent of the worksite employees are full-time, another 10 percent are part-time and the remaining 15 percent are temporary employees. The worksite dress code is business casual. The ETC describes the motivation for using commute alternatives as primarily a cost savings through the subsidy cost sharing through ridesharing and saving wear and tear on personal vehicles. The ETC says that ridesharers enjoy the camaraderie or catch up on reading during the commute. The ETC says that those who continue to drive their primary vehicles to work do so for the convenience of "just grabbing their keys and going" as well as a greater sense of security that they have transportation exactly when they want it for their purposes only.

There is a diverse group of employees at Weyerhaeuser, including scientists in research and development, accountants, human resources and administrative personnel. Depending upon what they do, the ETC observes a distinction among employee receptivity to using alternative transportation. For example, scientists tend to be more environmentally friendly, while accountants feel more pressed for time and are therefore less flexible about using alternative transportation. Administrative personnel are more willing to carpool and vanpool than upper management, because time and flexibility can be prioritized higher than cost savings by upper management. The ETC says that the majority of employees are positive about the CTR program.

\section{Overcoming External Factors}

There are many factors external to and outside the control of a worksite that can affect, positively or negatively, the success of a worksite commute trip reduction program. It appears that the Weyerhaeuser Freeways Program has responded programmatically to external factors outside its control to encourage use of alternative modes. Several examples are described here.

The roadways surrounding the worksite are multi-lane high speed thoroughfares. The ETC describes traffic conditions as an ' 8 ', on a scale of from ' 1 ' being free flow and ' 10 ' being gridlock. The ETC observed that traffic conditions have gotten worse in the past year and says that the worksite is in the middle of congested traffic conditions on both the freeways and streets.

When the worksite was first located in Federal Way in the early 1970's, there was abundant space in Federal Way. Weyerhaeuser Company was looking for a site for a large campus, long before there was traffic congestion and considerations about commute trip reduction. Since then, Federal Way has suburbanized considerably. The worksite is now in the middle of Federal Way. While there are many off-campus lunch and shopping opportunities within a 15-minute drive, Weyerhaeuser provides on-site amenities, including a bank, an exercise facility, the Weyerhaeuser Store and cafeterias, enabling and encouraging many employees to stay on campus during the lunch break. In addition, Weyerhaeuser belongs to the Federal Way Networking Association, composed of other businesses that meet on a monthly basis with the transit agencies to discuss issues and alternative commute promotional activities, and to encourage joint ridership with vanpool programs. Weyerhaeuser posts inquiries to other local 


\section{Weyerhaeuser Company}

\section{Puget Sound Area}

\section{Federal Way, Washington}

employers about vanpool seat vacancies and new vanpool start-ups to maximize opportunities for all employees to vanpool.

Within $1 / 4$ mile, there is the Federal Way Transit Center where buses arrive from Seattle, Tacoma, Bellevue and Renton every 30 minutes to one hour. The ETC said that employees would prefer to have additional transit service. Presently, a 15-minute car trip is experienced as an hour-long bus trip. To reduce that wait time, Weyerhaeuser provides a shuttle that operates on a schedule during the peak commuting periods. The shuttle picks up transit riders at the station and transports them directly to and from the worksite. In addition to the shuttle provided by Weyerhaeuser, local buses also drive by the Weyerhaeuser buildings to and from the Federal Way Transit Center. Weyerhaeuser provides a 100 percent subsidy for transit.

\section{Nature of the Business}

Weyerhaeuser's corporate region in the Puget Sound area of Washington State is composed of several worksites totaling about 3,000 employees. This corporate park has been located on a campus-like setting since 1977, containing several affected Weyerhaeuser worksites of 100 or more employees distributed across 500 acres. There are a total of 557 employees at the campus, of which 538 are affected by the Washington State CTR law. Since 1999, the number of employees has decreased from 880 in 1999 to 557 in 2004, partly due to layoffs as well as transfers to other sites. Over 180 employees from another Weyerhaeuser worksite at $8^{\text {th }}$ Avenue South are in the process of moving to this site. The labor shed is regional as evidenced by some vanpoolers who travel a one-way distance of over 80 miles.

The work week is 40 hours. While all employees work a single day time shift, the worksite has formalized flex schedule and telework guidelines. Approximately 2.5 percent of employees work a compressed work week (CWW) and over 15 percent of employees telecommute. The ETC observes that there is a positive alignment between top management and middle management in support of the commute trip reduction program. Senior management supports the telework and CWW programs but the actual use of it is up to the individual department managers. The different businesses or groups within Weyerhaeuser may use some portions of the CTR program more than others. For example, the IT department personnel may have more flexibility in the use of telework, while other job positions must be physically on hand.

The Weyerhaeuser Business Services (WBS) Department houses the commute trip reduction program, called the Weyerhaeuser Freeways Program. Other programs within WBS include travel, mailroom distribution, record management and archives. There also is a 'melting pot' of responsibilities within the WBS department that deals with transportation, including the Airport Express, the shuttle system, fleet vehicles and mobile equipment. This enables shuttle drivers to have multi-task jobs. For example, the shuttle is part of the Freeways Program, but the shuttle drivers also take care of all the fleet vehicles for the Corporate Region or work in records management. The airport shuttle is provided based on a request 24 hours in advance so that the drivers can be scheduled to provide the transportation service. 


\section{Weyerhaeuser Company}

Puget Sound Area

Federal Way, Washington

\section{Commute Trip Reduction Formation}

The Weyerhaeuser CTR program initially began with vanpool subsidies then later expanded to provide incentives for all alternative modes. In the beginning, some interested employees knew of vans offered by the transit agencies. They arranged for vanpooling on their own. Then Weyerhaeuser decided to develop a formalized commute trip reduction program in 1997 and hired an ETC. The ETC developed the program and hired four more individuals to assist program operations. Weyerhaeuser also started working with the local transit agencies to develop a Flexpass. This is a multitransit pass that is good throughout the County. It encompasses Inner City Transit, King County Metro, Pierce, and Sound Transit. Weyerhaeuser developed an extensive vanpool program, offering a 100 percent vanpool subsidy. Presently, there are 34 vanpools used by the Corporate Region, which are vans owned by Pierce, King County Metro and Inner City Transit.

A shuttle program also was started in 1997 that circulates among the buildings on campus and arrives every ten minutes. There are meetings for which employees ride the internal shuttle to different buildings on campus. Employees also ride the shuttle to lunchtime exercise classes and brought back to their offices afterward. There are two drivers that stay on a route in the campus and provide the routine scheduled internal shuttle service as well as other drivers that are available for special requests for trips off campus. The ETC believes the shuttle service is a great benefit to the company and to the employees. It saves on the taxi cab bill and parking costs. The shuttle services reduce travel time for the employees. There is also an airport express bus service provided for business travelers and visitors to the worksite.

The ETC describes the current program as "cafeteria style," with many options to meet the variety of individual travel needs. Weyerhaeuser has a web page and runs promotions to stimulate interest in the program. In 2003, 30 spaces were designated for carpools and vanpools. There are sidewalks, a bike lane, clothes lockers and showers. Weyerhaeuser provides a $\$ 25$ subsidy to each carpooler, bicyclist and walker per month. The ETC said that customer service is the most important element to successfully running the commute trip reduction program. For example, many bicyclists ride expensive bicycles. Weyerhaeuser provides bicycle parking that is secure and out of the rain.

The CTR program tries to eliminate as many barriers to using alternative transportation as possible. For example, the worksite provides guaranteed ride home, including use for when there is unexpected overtime. By advance reservation, the worksite also provides transportation to doctor, dentist, or vision appointments in the Federal Way area.

Incentives are offered to bikers, walkers, carpoolers and vanpoolers, based on how often they use the mode. All offered incentives are regularly utilized by the employees. An employee can use one or all of these modes if they choose to within any given month. Employees who use alternative transportation can earn up to $\$ 25$ per month in vouchers that come in $\$ 5$ increments that can be redeemed in the cafeteria, the Weyerhaeuser Store, and local participating merchants such as local gas stations, car washes, and REI sporting goods. There also is a monthly drawing 


\section{Weyerhaeuser Company}

Puget Sound Area

Federal Way, Washington

for teleworkers and CWW staff.

\section{Employee Transportation Coordinator}

The ETC works full time in the capacity of implementing the commuter trip reduction (CTR) program, overseeing all affected worksites at the corporate campus. The ETC works in the WBS Department (Weyerhaeuser Business Services) that is responsible for a combination of services supporting the campus. The ETC reports to a direct supervisor. The supervisor reports to a VP of WBS who reports to senior management. The ETC has access to the person who has control over the budget. The ETC can provide information and recommendations for enhancing the CTR program. The ETC has a crew who reports to him, including the shuttle drivers. The ETC has found several outside sources of support for the worksite CTR program, including an ETC network, a regional commuter assistance program, DOT staff, the local transit agency and collaboration with other nearby worksites.

The ETC has worked at Weyerhaeuser since 1997 and has served as an ETC since 2000. He specifically applied for the position. He has completed an ETC training class. The ETC communicates to employees via the "CTR Reader" electronic boards. He has an active worksite committee to assist with the program. The ETC's activities include distributing summary information to employees about the CTR program, providing information to new employees, posting materials, giving presentations to managers and staff, and conducting CTR events. He negotiates contracts with the transit agencies, assists his crew in day-to-day dilemmas and problems. He describes his position as a multitude of challenges for which he wears many hats, such as manager, dispatcher, negotiator and gofer. The ETC enjoys working with people the most, encouraging them to use alternative modes of transportation and assisting them. To help the ETC accomplish his job better, he would like to see a simplification of processes and procedures and a better utilization of promotions of the transit agencies. 
Organization Information (2004)

Weyerhaeuser Company

Federal Way, WA

Website:

www.weyerhaeuser.com

Primary Business:

Professional/Personal

Non-profit organization?

No

Total Employees:

557

Affected Employees:

538

Is the CTR program subject to collective bargaining? No

Does this worksite have multiple shifts?

No

Shifts description:

$\mathrm{N} / \mathrm{A}$

CTR program contact:

David Lantry

King County Metro

400 Yesler Way, MS YES-TR-0650, Seattle, WA 98104

Phone: (206) 684-1139

Email: david.lantry@metrokc.gov

\section{Worksite Characteristics (2004)}

Bus stop(s) Bike lane Sidewalk

Availability Availability Availability

Within $1 / 4$ mile

Onsite

Onsite
Restaurants Shopping Bank
Availability Availability Availability
Onsite Not available Onsite

\section{Worksite Parking and Parking Management Information}

\section{Parking management and monitoring (2004)}

Preferential parking is available for $2+$ carpools and vanpools. If you qualify and would like to have an HOV permit issued for your vehicle.

\begin{tabular}{|c|c|c|c|c|}
\hline \multicolumn{5}{|l|}{ Parking } \\
\hline Program & Total Num of & Onsite Parking & Offsite Parking & Leased Onsite \\
\hline Year & Employees & Spaces & Spaces & Parking Spaces \\
\hline 1999 & 880 & 822 & 0 & 0 \\
\hline 2000 & 731 & 822 & & 0 \\
\hline 2001 & 731 & 822 & 0 & 0 \\
\hline 2002 & 635 & 822 & 0 & 0 \\
\hline 2003 & 557 & 822 & & 0 \\
\hline 2004 & 557 & 822 & & 0 \\
\hline Program & Leased Offsite & Leased Or & e Parking & Leased Offsite Parking \\
\hline Year & Parking Spaces & Price $(\mathrm{Sp}$ & /Month) & Price (Space/Month) \\
\hline 1999 & 0 & & & \\
\hline 2000 & 0 & & & \\
\hline 2001 & 0 & & & \\
\hline 2002 & 0 & & & \\
\hline 2003 & 0 & & & \\
\hline 2004 & 0 & & & \\
\hline
\end{tabular}




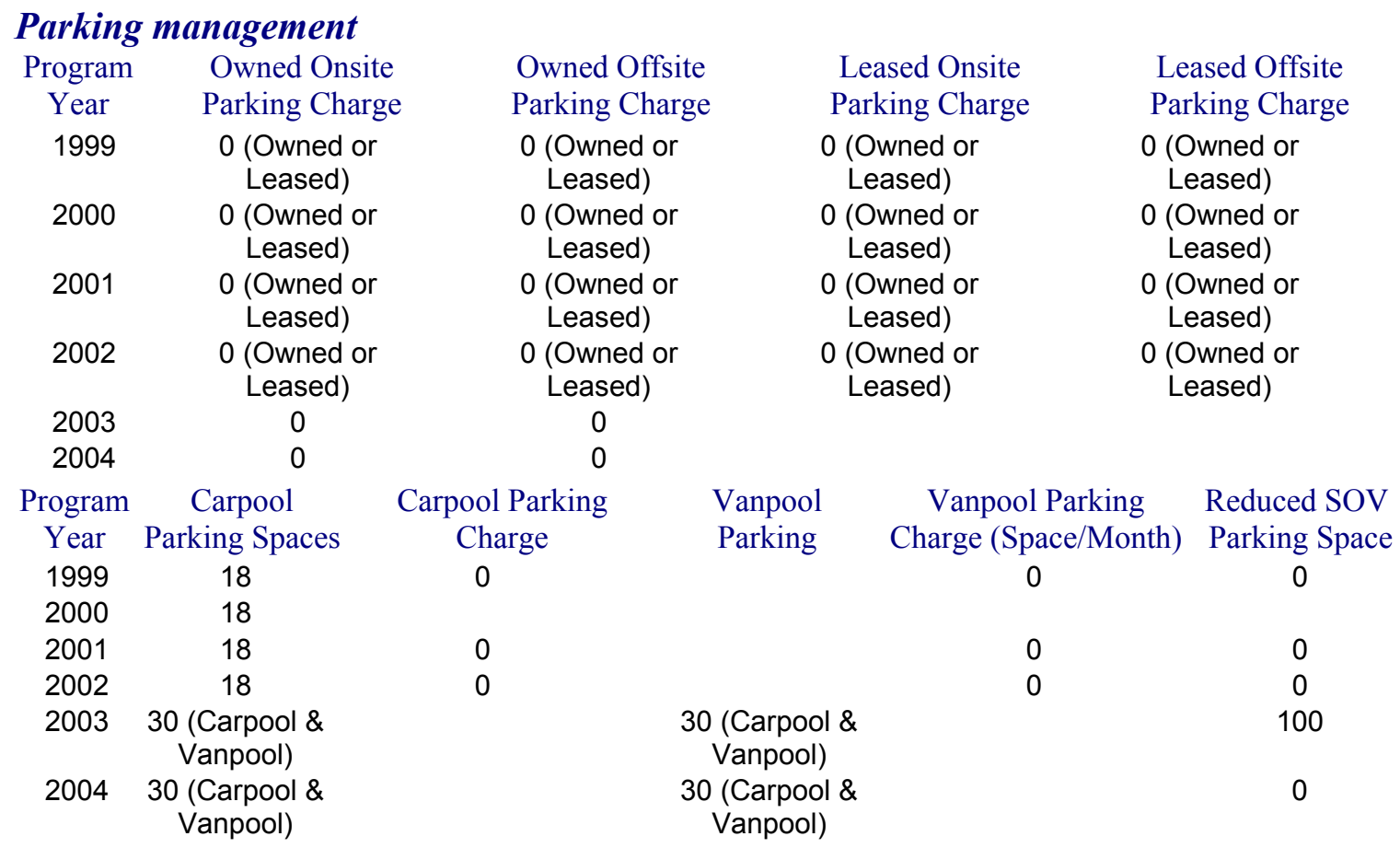

\section{Program Promotion}

\section{General (2004)}

Is the ETC's name, location and telephone number prominently displayed at this Yes

Displayed where? CTR Reader Electronic Boards

Has the ETC completed a program developer/ETC training course? Yes

On average, how many hours per week does the ETC spend on CTR activities? 40

Does the ETC have an active worksite committee to assist with the CTR Yes

\section{Program promotion}

\begin{tabular}{|c|c|c|c|c|c|c|}
\hline $\begin{array}{l}\text { Program } \\
\text { Year }\end{array}$ & $\begin{array}{c}\text { Distribute } \\
\text { Summary of CTR }\end{array}$ & \multicolumn{3}{|c|}{ Provide CTR Program } & $\begin{array}{c}\text { Post } \\
\text { Materials }\end{array}$ & $\begin{array}{c}\text { Give Managers } \\
\text { Presentation }\end{array}$ \\
\hline 1999 & Yes & & Yes & & Yes & Yes \\
\hline 2000 & Yes & & Yes & & Yes & Yes \\
\hline 2001 & Yes & & Yes & & Yes & Yes \\
\hline 2002 & Yes & & Yes & & Yes & Yes \\
\hline 2003 & Yes & & Yes & & Yes & Yes \\
\hline 2004 & Yes & & Yes & & Yes & Yes \\
\hline Program & Give & Conduct & Publish & Dist & bute & Distribute \\
\hline Year & Employees & CTR Events & CTR Articles & Informa & on with & Ridematch \\
\hline 1999 & Yes & Yes & Yes & $\mathrm{N}$ & & Yes \\
\hline 2000 & Yes & Yes & Yes & $\mathrm{N}$ & & Yes \\
\hline 2001 & Yes & Yes & No & $\mathrm{N}$ & & Yes \\
\hline 2002 & Yes & Yes & No & $\mathrm{N}$ & & Yes \\
\hline 2003 & Yes & Yes & No & $\mathrm{N}$ & & No \\
\hline 2004 & Yes & Yes & No & $\mathrm{N}$ & & No \\
\hline
\end{tabular}




\section{Site Amenities}

$\begin{array}{cccccc}\begin{array}{c}\text { Program } \\ \text { Year }\end{array} & \begin{array}{c}\text { Covered } \\ \text { Bicycle Spaces }\end{array} & \begin{array}{c}\text { Uncovered } \\ \text { Bicycle Spaces }\end{array} & \begin{array}{c}\text { Clothes } \\ \text { Lockers }\end{array} & \text { Showers } & \begin{array}{c}\text { Non-SOV On-site } \\ \text { Loading/Unloading }\end{array} \\ 1999 & \text { Yes } & \text { Yes } & \text { Yes } & \text { Yes } & \text { Yes } \\ 2000 & \text { Yes } & \text { Yes } & \text { Yes } & \text { Yes } & \text { Yes } \\ 2001 & \text { Yes } & \text { Yes } & \text { Yes } & \text { Yes } & \text { No } \\ 2002 & \text { Yes } & \text { Yes } & \text { Yes } & \text { Yes } & \text { Yes } \\ 2003 & \text { Yes } & \text { Yes } & \text { Yes } & \text { Yes } & \text { No } \\ 2004 & \text { Yes } & \text { Yes } & \text { Yes } & \text { Yes } & \text { No }\end{array}$

\section{Financial Subsidies, Incentives or Allowances}

\begin{tabular}{|c|c|c|c|c|}
\hline $\begin{array}{l}\text { Program } \\
\text { Year }\end{array}$ & $\begin{array}{c}\text { Transit Subsidy } \\
\text { (Employee/Month) }\end{array}$ & $\begin{array}{l}\text { Vanpool Subsidy } \\
\text { (Employee/Month) }\end{array}$ & $\begin{array}{l}\text { Carpool Subsidy } \\
\text { (Employee/Month) }\end{array}$ & $\begin{array}{l}\text { Walking Subsidy } \\
\text { (Employee/Month) }\end{array}$ \\
\hline 1999 & $100 \%$ subsidy & $100 \%$ subsidy & Up to $\$ 25$ & Up to $\$ 25$ \\
\hline 2000 & & & $\$ 25$ & $\$ 25$ \\
\hline 2001 & $100 \%$ subsidy & $100 \%$ subsidy & Up to $\$ 25$ & Up to $\$ 25$ \\
\hline 2002 & $100 \%$ subsidy & $100 \%$ subsidy & Up to $\$ 25$ & Up to $\$ 25$ \\
\hline 2003 & & & $\$ 25$ & $\$ 25$ \\
\hline 2004 & & $\$ 100$ & $\$ 25$ & $\$ 25$ \\
\hline $\begin{array}{l}\text { Program } \\
\text { Year }\end{array}$ & $\begin{array}{c}\text { Ferry Subsidy } \\
\text { (Employee/Month) }\end{array}$ & $\begin{array}{l}\text { Bicycling Subsidy } \\
\text { (Employee/Month }\end{array}$ & $\begin{array}{c}\text { Other Stipend } \\
\text { (Employee/Month) }\end{array}$ & \\
\hline 1999 & 0 & Up to $\$ 25$ & 0 & \\
\hline 2000 & 0 & $\$ 25$ & 0 & \\
\hline 2001 & 0 & Up to $\$ 25$ & 0 & \\
\hline 2002 & 0 & Up to $\$ 25$ & 0 & \\
\hline 2003 & 0 & $\$ 25$ & 0 & \\
\hline 2004 & 0 & $\$ 25$ & 0 & \\
\hline
\end{tabular}

\section{Fleet Vehicles and Special Programs}

\section{Employer provided vehicles availability}

$\begin{array}{cccccc}\begin{array}{c}\text { Program } \\ \text { Year }\end{array} & \begin{array}{c}\text { FV Guaranteed } \\ \text { Ride Home }\end{array} & \text { FV Vanpool } & \begin{array}{c}\text { FV } \\ \text { Carpool }\end{array} & \begin{array}{c}\text { FV Work- } \\ \text { Related Trips }\end{array} & \begin{array}{c}\text { FV Non-Work } \\ \text { Related Errands }\end{array} \\ 1999 & \text { No } & \text { No } & \text { No } & \text { No } & \text { No } \\ 2000 & \text { No } & \text { No } & \text { No } & \text { Yes } & \text { No } \\ 2001 & \text { No } & \text { No } & \text { No } & \text { No } & \text { No } \\ 2002 & \text { No } & \text { No } & \text { No } & \text { No } & \text { No } \\ 2003 & \text { Yes } & \text { Yes } & \text { Yes } & \text { No } & \text { No } \\ 2004 & \text { Yes } & \text { Yes } & \text { Yes } & \text { No } & \text { No }\end{array}$

\section{Other services availability}

$\begin{array}{cccc}\text { Program } & \text { Employer-Provided } & \text { Guaranteed Ride Home } & \text { Internal Match } \\ \text { Year } & \text { Shuttle } & \text { Program } & \text { Program } \\ 1999 & \text { Yes } & \text { Yes } & \\ 2000 & \text { Yes } & \text { Yes } & \\ 2001 & \text { Yes } & \text { Yes } & \\ 2002 & \text { Yes } & \text { Yes } & \text { No } \\ 2003 & \text { Yes } & \text { Yes } & \text { No } \\ 2004 & \text { Yes } & \text { Yes } & \end{array}$




\section{Mode Split and Vehicle Miles Traveled}

\begin{tabular}{|c|c|c|c|c|c|c|c|}
\hline $\begin{array}{l}\text { Program } \\
\text { Year }\end{array}$ & \multicolumn{2}{|c|}{$\begin{array}{l}\text { Num of Surveys } \\
\text { Distributed (Num of }\end{array}$} & \multicolumn{2}{|c|}{$\begin{array}{l}\text { Total Reported } \\
\text { Commuting Days }\end{array}$} & $\begin{array}{c}\text { Driving } \\
\text { Alone }\end{array}$ & Carpooling & Vanpooling \\
\hline 1993 & 76 & & 25 & & $84.9509 \%$ & $8.0943 \%$ & $4.5187 \%$ \\
\hline 1995 & 86 & & 27 & & $79.2241 \%$ & $11.7839 \%$ & $6.2001 \%$ \\
\hline 1997 & 76 & & 22 & & $66.3163 \%$ & $21.1126 \%$ & $5.8695 \%$ \\
\hline 1999 & 73 & & 24 & & $65.5901 \%$ & $14.8240 \%$ & $12.0497 \%$ \\
\hline 2001 & 57 & & 16 & & $68.6747 \%$ & $13.1928 \%$ & $14.3373 \%$ \\
\hline 2003 & 54 & & 16 & & $66.0224 \%$ & $16.8953 \%$ & $14.8379 \%$ \\
\hline Program & Public & Bicycling & Walking & Other & & hicle Miles & \\
\hline Year & Transit & & & & & Traveled & \\
\hline 1993 & $0.1179 \%$ & $0.5894 \%$ & $0.6287 \%$ & 1.1002 & & 13.56 & \\
\hline 1995 & $0.2175 \%$ & $0.7252 \%$ & $0.3263 \%$ & 1.5228 & & 13.46 & \\
\hline 1997 & $0.8760 \%$ & $0.8760 \%$ & $0.2628 \%$ & 4.6868 & & 11.73 & \\
\hline 1999 & $0.2484 \%$ & $0.5797 \%$ & $0.5383 \%$ & 6.1698 & & 11.77 & \\
\hline 2001 & $0.3012 \%$ & $1.0843 \%$ & $0.4217 \%$ & 1.9880 & & 11.85 & \\
\hline 2003 & $0.3741 \%$ & $0.8105 \%$ & $0.5611 \%$ & 0.4988 & & 11.85 & \\
\hline
\end{tabular}

\section{Compressed Work Week, Flex Time and Teleworking}

\section{Policy (1999)}

Flex Time

Weyerhaeuser is in the process of formalizing the flexible work schedule guidelines. They will be completed and implemented by 01/1999

Teleworking

Weyerhaeuser is in the process of formalizing the telework guidelines. They will be completed and implementedby 01/1999

\section{Percentage of employees on Compressed Work}

\begin{tabular}{ccccc}
$\begin{array}{c}\text { Program } \\
\text { Year }\end{array}$ & $\begin{array}{c}\text { Num of Surveys } \\
\text { Distributed (Affected }\end{array}$ & $\begin{array}{c}\text { Total Surveys } \\
\text { Reported }\end{array}$ & $\begin{array}{c}\text { Percentage of Employees } \\
\text { On 5 Days/Week }\end{array}$ & $\begin{array}{c}\text { Percentage of Employees } \\
\text { On 3 Days/Week }\end{array}$ \\
1993 & 765 & 519 & $97.1098 \%$ & $0.1927 \%$ \\
1995 & 867 & 568 & $95.7746 \%$ & $0.3521 \%$ \\
1997 & 767 & 480 & $91.6667 \%$ & $0.2083 \%$ \\
1999 & 731 & 505 & $92.6733 \%$ & $0.1980 \%$ \\
2001 & 578 & 370 & $94.5946 \%$ & $0.2703 \%$ \\
2003 & 547 & 347 & $95.3890 \%$ & $0.0000 \%$ \\
Program & Percentage of Employees & Percentage of Employees & Percentage of Employees \\
Year & On 4 Days/Week & On 7 Days/Two Weeks & On 9 Days/Two Weeks \\
1993 & $0.9634 \%$ & \multicolumn{2}{c}{$0.0000 \%$} & $0.1927 \%$ \\
1995 & $2.1127 \%$ & \multicolumn{2}{c}{$0.1761 \%$} & $0.5282 \%$ \\
1997 & $5.6250 \%$ & \multicolumn{2}{c}{$0.0000 \%$} & $1.2500 \%$ \\
1999 & $4.3564 \%$ & \multicolumn{2}{c}{$0.1980 \%$} & $1.5842 \%$ \\
2001 & $2.7027 \%$ & \multicolumn{2}{c}{$0.2703 \%$} & $1.0811 \%$ \\
2003 & $2.5937 \%$ & $0.0000 \%$ & $0.2882 \%$
\end{tabular}

\section{Percentage of employees on Telecommuting}

$\begin{array}{ccccc}\begin{array}{c}\text { Program } \\ \text { Year }\end{array} & \begin{array}{c}\text { Num of Surveys Distributed } \\ \text { (Num of Affected Employees) }\end{array} & \begin{array}{c}\text { Total Surveys } \\ \text { Reported }\end{array} & \begin{array}{c}\text { Total Percentage } \\ \text { of Telecommuters }\end{array} & \begin{array}{c}\text { 1 Days every } \\ \text { Two Weeks }\end{array} \\ 1993 & 765 & 523 & 2.2945 \% & 1.1472 \% \\ 1995 & 867 & 570 & 7.0175 \% & 3.8596 \% \\ 1997 & 767 & 487 & 15.6057 \% & 9.2402 \% \\ 1999 & 731 & 508 & 15.7480 \% & 6.6929 \% \\ 2001 & 578 & 359 & 15.3203 \% & 6.6852 \% \\ 2003 & 547 & 344 & 15.6977 \% & 6.3953 \%\end{array}$




$\begin{array}{cccccc}\begin{array}{c}\text { Program } \\ \text { Year }\end{array} & \begin{array}{c}\text { 2 Days every } \\ \text { Two Weeks }\end{array} & \begin{array}{c}\text { 3 Days } \\ \text { every Two }\end{array} & \begin{array}{c}\text { 4 Days every } \\ \text { Two Weeks }\end{array} & \begin{array}{c}5 \text { Days every } \\ \text { Two Weeks }\end{array} & \begin{array}{c}\text { More than 5 } \\ \text { Days every Two }\end{array} \\ 1993 & 0.7648 \% & 0.1912 \% & 0.1912 \% & 0.0000 \% & 0.0000 \% \\ 1995 & 1.9298 \% & 0.3509 \% & 0.7018 \% & 0.0000 \% & 0.1754 \% \\ 1997 & 3.9014 \% & 1.4374 \% & 0.4107 \% & 0.2053 \% & 0.4107 \% \\ 1999 & 4.1339 \% & 2.1654 \% & 1.3780 \% & 0.7874 \% & 0.5906 \% \\ 2001 & 6.4067 \% & 1.3928 \% & 0.8357 \% & 0.0000 \% & 0.0000 \% \\ 2003 & 6.3953 \% & 1.1628 \% & 1.4535 \% & 0.2907 \% & 0.0000 \%\end{array}$




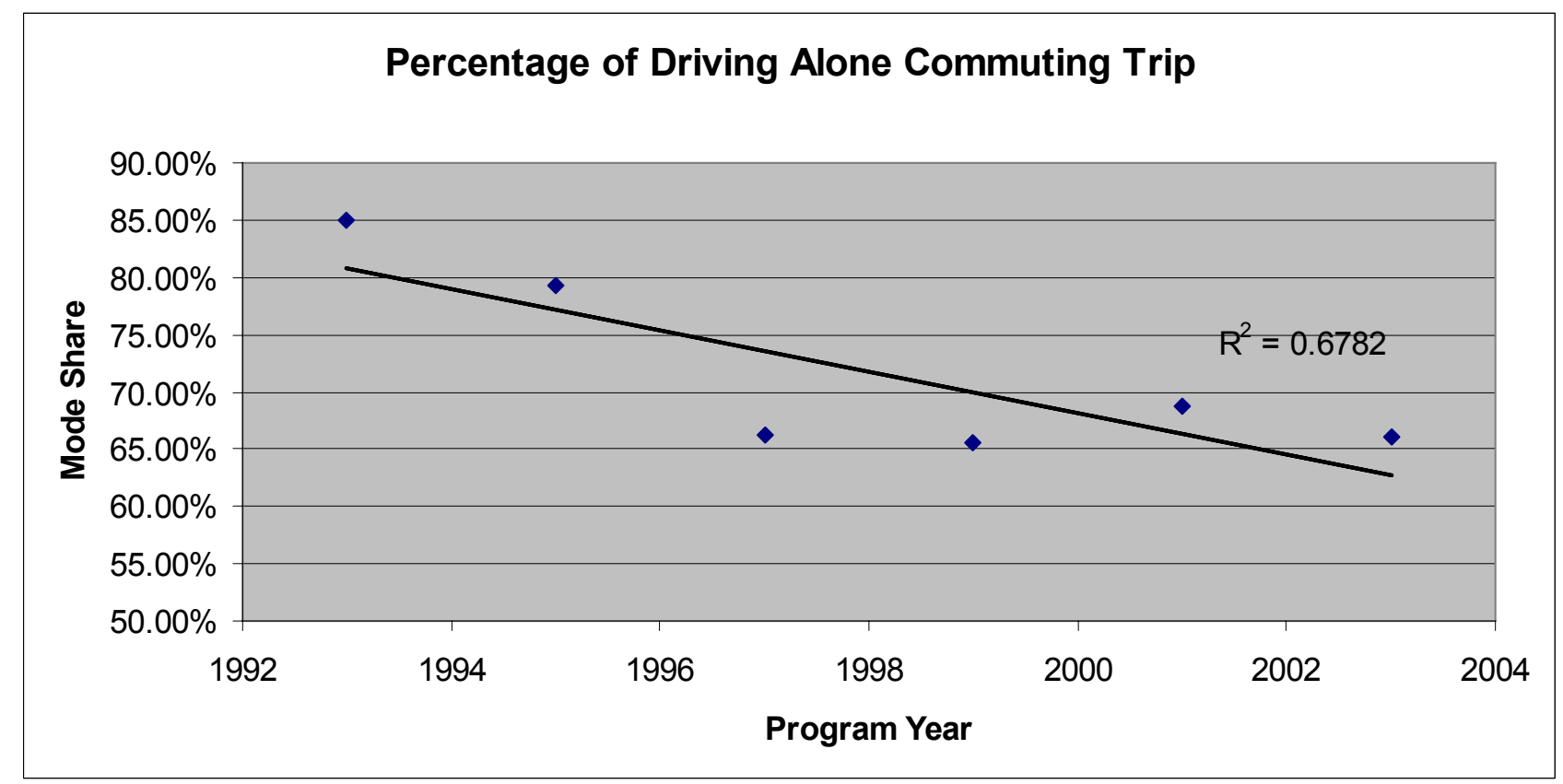

Figure 23: Percentage of Drive-Alone Commute Trips - Weyerhaeuser Co.

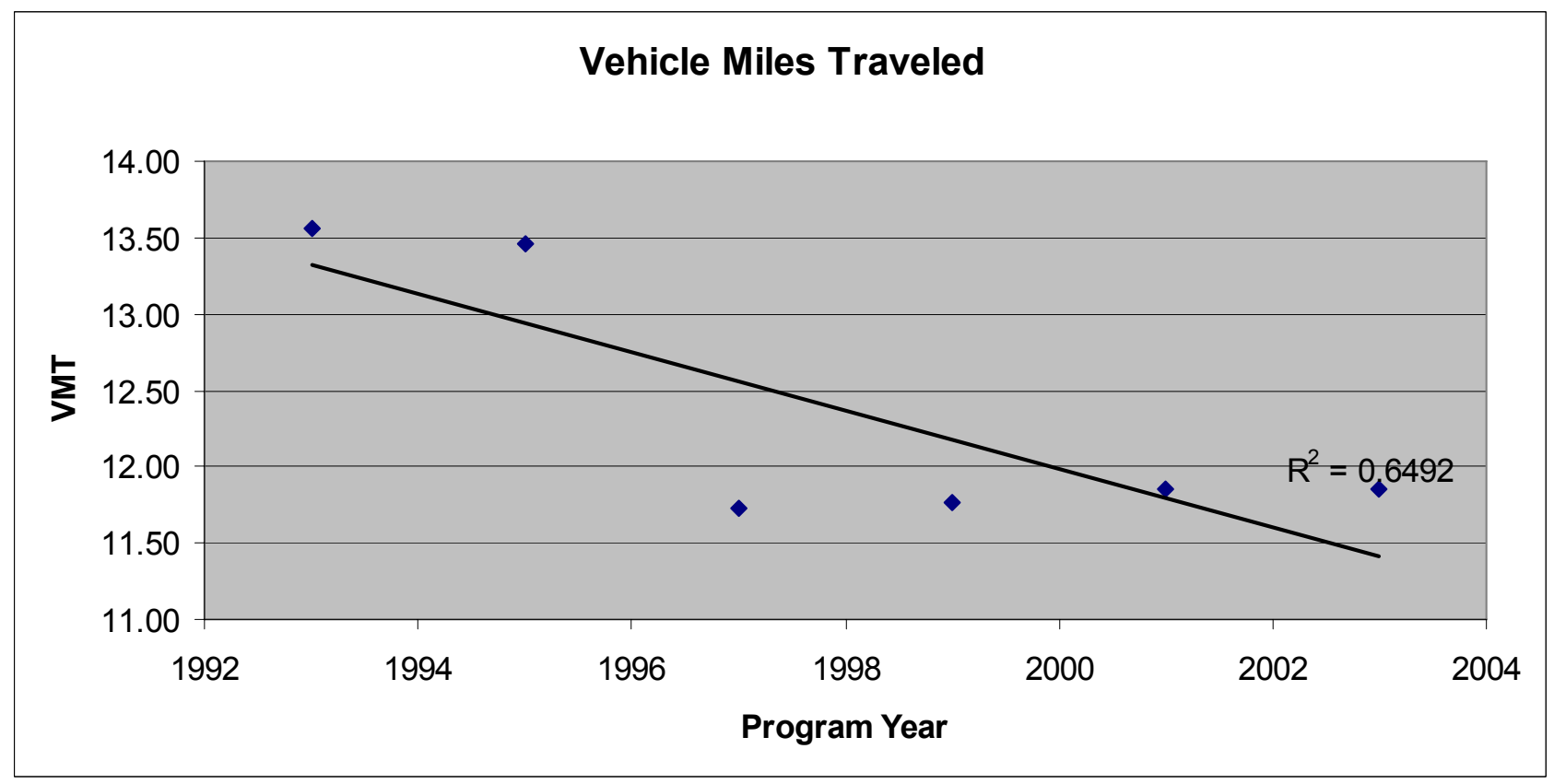

Figure 24: VMT - Weyerhaeuser Co. 


\section{Appendix B:}

Letter of Study Introduction sent to Employee Transportation Coordinators

IRB Informed Consent Form

Survey instrument

Interview Guide 


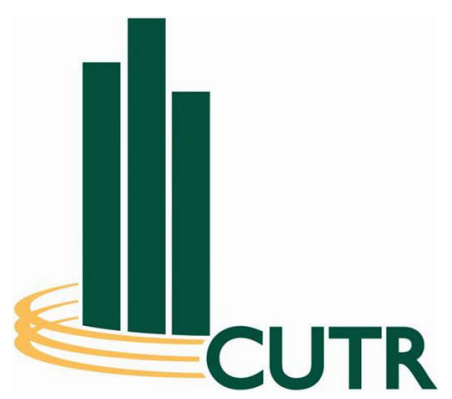

Center for Urban Transportation Research

University of South Florida

4202 East Fowler Avenue, CUT 100

Tampa Florida 33620-5375

(813) 974-3120

SunCom 574-3120

Fax (813) 974-5168

Web: http://www.cutr.usf.edu

Date: August 1, 2006

To: Employee Transportation Coordinator

From: Sara J. Hendricks, AICP, PI Brian Lagerberg

Senior Research Associate Manager

Center for Urban Transportation Research Washington State Dept of Transportation

University of South Florida

4202 East Fowler Avenue, CUT100

Public Transportation and Rail Division

Tampa, FL 33612-5375

P.O. Box 47387

Olympia, WA 98504-7387

\section{RE: Featuring your Worksite in Case Study Research \\ Project Overview and Informed Consent \\ Study Title: "National Smart Transportation Archive Researcher" (NSTAR) \\ Institutional Review Board \#104643}

As the Employee Transportation Coordinator (ETC) of your worksite, I seek your participation in a survey and 45-minute telephone interview for the development of case study examples of successful worksite Commute Trip Reduction (CTR) programs. This is part of a research study. We are aware that some worksites are frequently contacted for information about their programs and our goal is to minimize the time we ask of you.

\section{The Problem That This Research Addresses}

Traffic congestion in urban areas is a major cost to society in lost time and productivity as well as the production of green house gases and air pollution. As urban areas continue to grow, building more roads is becoming a less practical option, due to growing expense, environmental impacts, legal issues, land unavailability and neighborhood opposition. Part of the solution is offering more mobility options and reducing the need to travel. This approach is commonly known as transportation demand management (TDM). This research project, the National Smart Transportation Archive Researcher (NSTAR), ultimately seeks to make TDM strategies more useful and helpful to commuters.

\section{Purpose of this Research Study}

Over the years, there has been an increase in requests from employers nationwide for information about the use of various combinations of trip reduction strategies at worksites and their effects upon commuter travel behavior. This information has also been sought by transportation professionals for planning purposes and by commuter assistance programs to assist employers. Worksite ETCs have valuable 
information to share and practical insight and know-how from years of combined experience with running CTR Programs. While ETC networking commonly takes place at the local and regional levels, there remains no central source for such information dissemination nationwide. The purpose of this research study, NSTAR, is to fill this information need by creating a national online, searchable and updatable database of case studies about trip reduction programs. The NSTAR archive is being offered in response to the 59 percent of respondents to the 2001 Association for Commuter Transportation Endof-Year Survey who requested that TDM-oriented statistics and case studies be developed. We are coordinating with the Association for Commuter Transportation in this study. This archive will be part of the National TDM and Telework Clearinghouse Helpdesk, located at http://www.nctr.usf.edu/clearinghouse.

This database will be used by others to create and modify their own trip reduction programs to make them cost effective and more beneficial to employees. The area where you work within the state of Washington, has some of the most extensive information about CTR programs. We received contact information for your worksite through the database of trip reduction programs of the Washington State Department of Transportation. While this database contains information from worksite annual reports and travel surveys, we seek to develop more in-depth profiles of worksites that have experienced success with their programs. Your worksite has been selected among forty others having the more successful commute trip reduction programs. We are contacting you because your worksite trip reduction program has demonstrated a consistent trend of reduction in vehicle miles traveled and in the drive alone mode share.

\section{Study Benefits}

As the NSTAR archive grows and provides more comprehensive information on trends for each case study, the case studies will become increasingly useful to ETCs and transportation professionals. The benefits of this study are twofold. First, by gathering, organizing and providing information about worksite Commute Trip Reduction programs, this will enable worksite ETCs and other transportation professionals to share nationally what program elements have worked well for their organizations in addition to what circumstances have affected implementation. Second, this database development provides researchers with the information needed to analyze the influence of internal and external factors and to generalize about what yields good results. The results of this project are intended to provide up-to-date information about strategies used to reduce trip making and the results of those strategies within the context of the particular worksite.

\section{Study Funding and Sponsorship}

NSTAR is staffed through the National Center for Transit Research (NCTR). NCTR is one of ten competitively designated and federally funded university research centers in the United States, housed at the Center for Urban Transportation Research, College of Engineering at the University of South Florida (USF) in Tampa. NSTAR is sponsored by the Florida Department of Transportation with funding from the Federal Transit Administration of the United States Department of Transportation.

\section{Guidelines for Participation}

Your participation is completely voluntary. Upon receipt of your informed consent to participate in this research, you would complete a survey that will be emailed or faxed to you. For follow-up and clarification, an interview time, not to exceed 45 minutes, would be prearranged at a time convenient to you. A carefully developed guide of interview questions would be forwarded to you in advance. You 
may choose to decline answering any of the questions. If you think that answering just the questions do not provide a good explanation, you are encouraged to add information that you think is pertinent to explaining the success and impact of your trip reduction program.

There are no anticipated risks of participating in this study. You will not be paid for your participation in this study. Aside from your time, there will be no other costs to participate in this study. If you agree to participate, the information you provide will be used to develop a published report and be added to the database for NCTR. The report and database will be available online to the public. The name of your organization will be listed in the report and in the database and you will be referred to as "the ETC". Your personal name will not be used. If a future NSTAR archive user has questions after reading about your worksite, they will be referred to your municipal commuter trip reduction program contact who provides programmatic support and guidance. After the case study write-up is complete, I will email or fax it to you for your review, prior to using it in the on-line NSTAR archive.

The interviews will take place during the months of August and September 2006. We will ask to audiotape the telephone interviews. If you choose to participate in the study by being interviewed, you may decline being audiotaped if you prefer. Your privacy and research records will be kept confidential to the extent of the law. Authorized research personnel, employees of the Department of Health and Human Services, and the USF Institutional Review Board, its staff and other individuals acting on behalf of USF, may inspect the records from this research project.

\section{Contacts for Questions}

If you have any questions about this research study, contact Sara J. Hendricks, Principal Investigator, at (813) 974-9801 or by email at Hendricks@cutr.usf.edu. If you have questions about your rights as a person who is taking part in a research study, you may contact the Division of Research Integrity and Compliance of the University of South Florida at (813) 974-5638.

Sincerely,

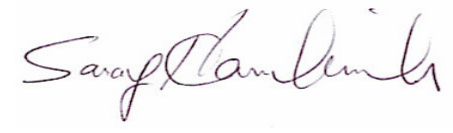

Sara J. Hendricks

CUTR Principal Investigator

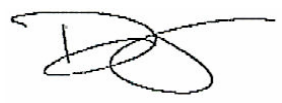

Brian Lagerberg Manager, WSDOT 


\section{$\underline{\text { Informed Consent }}$}

\section{National Smart Transportation Archive Researcher Institutional Review Board \#104643}

\section{PLEASE COPY THE FOLLOWING STATEMENT AND FORWARD IT BACK BY EMAIL TO hendricks@cutr.usf.edu OR FAX IT TO THE ATTENTION OF SARA HENDRICKS AT (813) 974-5168.}

Following receipt of this consent form, you will be contacted to arrange a telephone interview.

By emailing or faxing back this form, I am expressing consent to participate in this research study. I agree that:

- I have fully read this informed consent form describing this research project.

- I have had the opportunity to question the person in charge of this research and have received satisfactory answers.

- I understand that I am being asked to participate in research. I understand the risks and benefits, and I freely give my consent to participate in the research project outlined in this form, under the conditions indicated in it.

- I have been given a copy of this informed consent form, which is mine to keep.

- I understand that if I choose to participate in this study by being interviewed by telephone, I may also choose to decline being audiotaped.

\section{Investigator Statement:}

I certify that participants have been provided with an Informed Consent form that has been approved by the University of South Florida's Institutional Review Board and that explains the nature, demands, risks, and benefits involved in participating in this study. I further certify that a phone number has been provided in the event of additional questions.

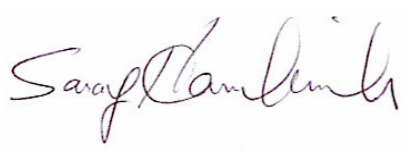

Sara J. Hendricks, AICP

Principal Investigator

Date:

Mailing address at:

My phone number is: ext.

Name:

Title:

Organization:

cc: Division of Research Integrity and Compliance University of South Florida 
162 


\section{National Smart Transportation Archive Researcher (NSTAR) Initial Survey}

Thank you for agreeing to participate in the NSTAR project. The following survey is designed to collect some information about your organization's trip reduction program that is not collected by the Employer Annual Report \& Program Description you fill out for the Washington State's Commute Trip Reduction Program. The survey results will also help us develop an individualized interview guide for the follow-up telephone interview.

The survey is a write-protected Microsoft Word document. This means that you can tab between the fields to fill in your answers. For the check boxes, the first click places an " $X$ " in the box and if you want to change your answer, all you have to do is click it again to remove the " $X$ ". For the field boxes, just tab to them and begin typing in your answers. The fields allow for unlimited characters so feel free to elaborate.

Once you complete the survey, please save the document and email it back to Chris Hagelin at hagelin@cutr.usf.edu or you could print it out, fill in your answers by hand and fax it to 813-974-5168.

If you have any questions, please feel free to contact Chris Hagelin at 813-974-2977 or hagelin@,cutr.usf.edu or Sara Hendricksat813-974-9801 or hendricks@.cutr.usf.edu

\section{Worksite Characteristics}

1. Is your worksite the sole location of your organization or are there other worksites within your organization?

Single site

Multiple worksite locations

1A.If multiple worksite locations exist, is your commuter trip reduction program centrally managed or decentralized and managed at your worksite?

\section{Centrally managed}

Decentralized and managed at each individual worksite

2. In what kind of setting is your worksite located?
Downtown central business district
Corporate office park
Industrial park
Suburban commercial area
Other: please describe

3. Is your worksite located in its own building or in a building with multiple employers?

Own building

In a building with multiple employers

4. How long has your worksite been at its present location? 
5. Has your organization ever moved locations?

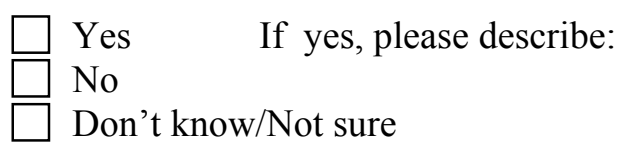

6. Please check all that apply to your parking conditions? If both on-site and off-site parking available, please fill out both sections.

$\begin{array}{lll}\square \text { On-site } & \square \text { Free to employees } & \square \text { Sufficient spaces available } \\ \square \text { Not free } & \square \text { insufficient spaces available } \\ \square \text { Off-site } & \square \text { Free to employees } & \square \text { Sufficient spaces available } \\ & \square \text { Not free } & \square \text { insufficient spaces available }\end{array}$

7. Are there any reserved parking spaces for any particular tier or department of employees?

$\square$ Yes $\quad$ If yes, please describe:
$\square$ No

8. Is there public parking available within walking distance (1/4 mile) of your worksite?

$\square$ Yes If yes, what is the cost: $\$ \quad \square$ per hour $\square$ per day $\square$ Not sure
$\square$ No
$\square$ Don't know/Not sure

\section{Worksite Accessibility to Public Transit/Regional Accessibility}

9. How far is the nearest transit stop from your worksite?

On-site

Within 3 blocks

$1 / 4$ mile away

No transit stops nearby

Don't know/Not sure

10. How frequently does transit arrive during peak hours of commuting?

About every 5 minutes

About every 10 minutes

About every 15 minutes

About every 30 minutes or more

Other: please describe:

Don't know/Not sure 
11. How would you describe the roads surrounding your worksite?

Dense grid of streets as found in a downtown

Major highways

Multi-lane, high speed roads as found in a sprawl environment

Rural roads

Other: please describe:

12. On a scale of 1 to 10 , one being total free flowing traffic and 10 being total gridlock congestion, what are the traffic conditions like surrounding your worksite at peak commute times?

13. Has traffic congestion changed in the past year?

Much worse $\square$ Worse $\square$ About the same $\square$ Better $\square$ Much better

\section{Availability of Outside Support}

14. Does your worksite trip reduction program use help from sources of outside support?

$\square$ TMA
ETC network
Regional commuter assistance program
DOT staff
Collaborating with other nearby worksites
Other: please describe

\section{Employee Characteristics}

15. Would you describe the company's workforce in terms of the type of job classifications employed? Check all that apply and elaborate if necessary:

$\square$ Primarily a unionized workforce

$\square$ Primarily a highly paid workforce

Blue-collar

White-collar

Professional

$\square$ Highly skilled workforce

$\square$ Other: please describe

16. Approximately what percent of your employees are:
$\%$ Full-time
\% Part-time
$\%$ Temporary help 
17. Does your worksite employ primarily:

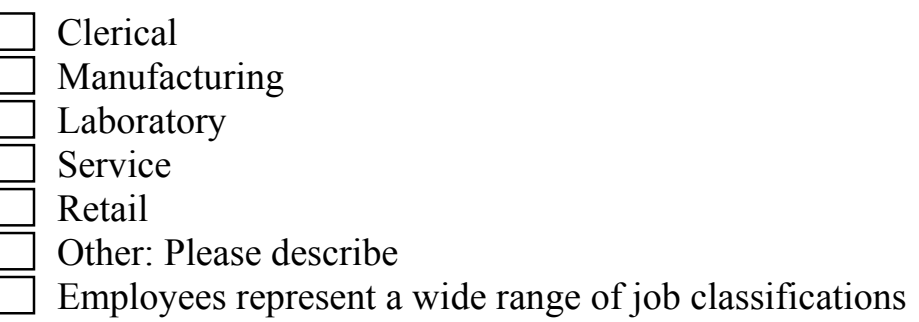

\section{Nature of Business}

18. Does your organization have an adopted mission statement and/or vision?

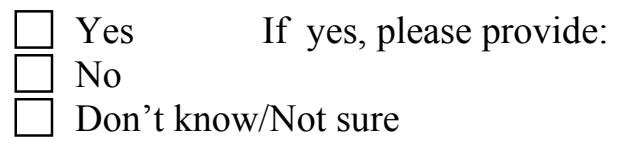

19. How would you describe your worksite's dress code?

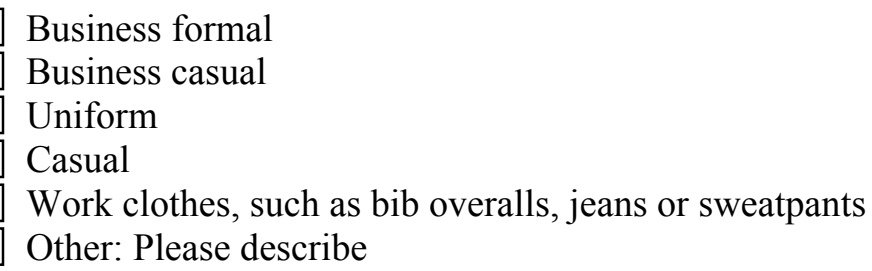

\section{Commuter Assistance Program}

20. Have there been any major changes to your commuter assistance programs since the last annual Commute Trip Reduction survey?

$$
\begin{aligned}
& \text { Yes If yes, please describe: } \\
& \text { No } \\
& \text { Don't know/Not sure }
\end{aligned}
$$

21. Is your employer required to participate under the Commute Trip Reduction Law?

$$
\text { Yes }
$$

No, voluntary participant 
22. How would you describe the business philosophy of top management with regard to efforts to change employee travel behavior? Is it seen as (select one that fits best):

A CTR program that is adverse to the mission of the organization and the organization will do no more than necessary to comply with the law.

A CTR program that is unrelated to the mission of the organization and the organization will do no more than necessary to comply with the law

A CTR program that is unrelated to the mission of the organization but the organization is committed to generously complying with the law because:

- $\square$ The organization believes that if it must do something, don't do it half way but do it in the best possible way.

- $\square$ It is important to demonstrate support for the community.

$\square$ A CTR program that is philosophically aligned with the mission of the organization and so it is a natural fit to incorporate trip reduction activities into the way that business is conducted.

A CTR program that makes good business sense to the organization because it provides benefits that make the business more profitable (aids recruitment, retention, decreases tardiness/absenteeism, cuts space/parking costs) so CTR program costs are seen as a business investment.

A CTR program is an opportunity to demonstrate corporate responsibility in mitigating industrial impacts of the business.

Other: please describe

23. Has your worksite ever nominated itself for an award relating to its trip reduction programs?

$$
\begin{aligned}
& \text { Yes If yes, please describe: } \\
& \text { No } \\
& \text { Don't know/Not sure }
\end{aligned}
$$

24. How long have you served as ETC?

25. Have you worked as an ETC at other worksites or companies before this?

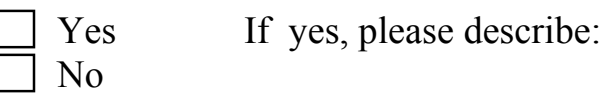

26. In which department are you located?

27. What is your job title by which the employees know you?

28. Do you have your own office?
Yes
If yes, please describe:
No 
29. Are your ETC duties explicitly listed as part of your written job description?

$\square$ Yes
$\square$ No
$\square$ Don't know/Not sure

30. Were you assigned the job as ETC or did you volunteer for it?

$\square$ Yes

$\square$ No 
National Smart Transportation Archive Researcher (NSTAR)

IRB \#104643

Sara J. Hendricks, (813) 974-9801, Hendricks@cutr.usf.edu

\section{Interview Guide}

Name of Interviewee:

Organization:

Phone:

Date:

\section{Introductory Information}

Good morning. This is Sara Hendricks from CUTR. We have spoken before and arranged to conduct an interview about your worksite trip reduction program at this pre-arranged time. Is today and this time still okay?

Yes. Then continue with interview.)

No. Reschedule date/time )

I forwarded to you a copy of this Interview Guide, which contains the questions that I would like to ask. Have you had a chance to look at it?

Just to review, your worksite was chosen as an example of one having a documented trend of decreasing single-occupant vehicle mode share and decreasing vehicle miles traveled, which is the sort of performance that you should feel proud to report. The result of this interview with you and about 10 other ETCs in the Seattle area will be individual case study write-ups that will be available to TDM professionals and worksite ETCs nationwide as part of the NSTAR archive. This archive will be part of the National TDM and Telework Clearinghouse Helpdesk, located at http://www.nctr.usf.edu/clearinghouse

This information will help others to craft their own worksite trip reduction programs as well as provide municipalities with information on how to assist worksites. Over time, we will be continuing to add and update the archive, to include more worksite case studies.

The name of your worksite will be listed in the archive and you will be referred to as "the ETC". Your personal name will not be used. If a future NSTAR archive user has questions after reading about your worksite, they will be referred to your municipal commuter trip reduction program contact who provides programmatic support and guidance.

There are no "right" or "wrong" answers to the interview questions. Whatever commuting behavior and patterns that are found at your worksite are perfectly valid, based upon an understanding that every commuter will choose the best, most rational way to travel for himself or herself. Our main objective in 
this interview is to understand what actually happens with regard to commuter travel and what motivates commuters to select their travel choices.

While your participation will be most helpful to this project by answering as many questions for which you confidently know the answers, you may choose to answer just some or none of the questions. It is also okay to tell me you don't know the answer to a question. For questions seeking factual answers, you might decide that someone else in your organization might be better able to answer some questions and refer me to that person. In this case, I will seek their voluntary participation. Some questions call for your observations and perceptions rather than "the facts." Some questions might seem redundant to you. Where the same information answers more than one question, we will move more quickly over them. However, this will differ from one worksite to another. This Interview Guide is meant to be used as a flexible tool, composed of proposed questions only. These questions were carefully developed based upon previous related research. The questions aim to pick up nuances and variations. While I will ask only the questions listed, you may choose to describe your organization's program effectiveness in another way if you think it would provide better explanation.

For several questions in this Interview Guide, I reference information formerly provided by your worksite from the 2002 version of the Washington State Commuter Trip Reduction Employer Annual Report \& Program Description. This reference appears as a question number (Q\#_).

Identification of special challenges and obstacles experienced by a worksite and how the worksite is attempting to address them is often more instructive than a story of easy success. As one commuter assistance program director who is a reviewer for this project said, "I cannot stress nearly enough how important it is to document failures as well as successes. It's always helpful to know that something was tried and didn't work and why it didn't work." (Sandra Moody, Bay Area Commuter Services, Tampa, FL) Alternatively, the results of some other worksite trip reduction programs may be straightforward and uncomplicated. All stories are valuable. These case studies are being developed under the hypothesis that trip reduction program success is the result of some combination of external conditions (outside the worksite) and those internal to the worksite. We hope to better understand what combinations work well together as well as identify commonalities and uniqueness among the successful trip reduction programs.

Furthermore, after the case study write-up is complete, I will email or fax it to you for your review, prior to using it in the on-line NSTAR archive, which will be available to the public, as well as before publishing it in a "Best Practices..." Final Report, which is a government report that will also be available to the public.

Are you ready to begin the interview? If you have any questions about myself, or the project, now or at any time during the interview, I will be happy to answer them. I would like to record this interview, so that I can listen carefully without having to scribble notes. Is that okay with you?

yes. Okay, I am going to turn on the tape recorder now.

no. Okay, I will not use the tape recorder. 


\section{Conditions External to Your Worksite}

\section{Worksite Accessibility to Public Transit / Regional Accessibility}

1. We know that good accessibility to high quality public transit service is important to enable worksite employees to use transit. We also know that the transit service must provide good regional accessibility. The survey data for your worksite $(\mathrm{Q} \# 44)$ indicated that there is a bus stop (circle one): on site, within 3 blocks, $1 / 4$ mile away, no bus stop nearby. How would you describe the quality of the transit service that serves your worksite? Is it adequate to reasonably allow employees to use it for commuting? (Frequency, duration, origin-destination connections, on-schedule, clean, etc.)

2. How do employees describe transit service quality to you?

3. Are there a number of employees who could reasonably use transit but choose not to? What are their reasons?

4. How would you describe the roadway system surrounding your worksite? For example, is it surrounded by a dense grid of streets as commonly found in a downtown? Is it along a major high speed highway in a suburban or rural area? Is it along a busy corridor with frequent traffic signals? Is it easily accessed from a nearby interstate exit?

\section{Land Use Configuration of Surrounding Area}

1. During employees' breaks, such as lunch, are employees expected to stay at the worksite during this time or can they leave the worksite? How long is the break? Do employees actually leave the worksite during their lunch break?

2. The survey mentions (Q\#49-52) that there are opportunities for (circle all that apply) shopping, restaurants, ATM/banks, child care, personal services (dentist, haircut), either on-site or within walking distance. In your opinion, is there a sufficient number and variety of nearby shopping, restaurants, banks, child care, personal services, etc. to attract people to walk to these places from the worksite?

3. Sometimes the opportunity or necessity to link trips (for example, traveling from work to the grocery store, then home) makes it difficult to use alternative transportation. For those who link trips after the work day, do they stop by places before their trip home or do they stop at places closer to their home neighborhood?

\section{Public parking availability}

1. Aside from any parking that your worksite provides to employees, what is the public parking situation within walking distance of your worksite $(\mathrm{Q} \# 59)$ ? Is it easy to find? Inexpensive? Restricted use? 
2. Your survey data indicates that there are \#_ CTR-affected employees (Q\#20) and \# on-site spaces for employee use $(\mathrm{Q} \# 53)$. $\overline{\text { How }}$ do employees perceive the availability of parking?

\section{Traffic Conditions}

1. What is your opinion of the level of traffic congestion that employees encounter? Is congestion "bad enough" to motivate motorists to use public transit?

2. Is it worth the state requirements for the most populous counties to require employers with over 100 employees to implement trip reduction plans?

3. How do you perceive employees at your worksite think about the traffic congestion problem?

4. For employees who use alternative modes, such as transit or ride sharing, what is the primary reason why they use an alternative mode? For example, reasons might be cost savings, time savings, freedom from driving, other

5. For employees who continue to drive their private automobiles alone, what are the primary reasons they do so? Reasons might be need to link trips, need car during the day, time savings, pick up child at daycare, other

6. For those who recently changed modes of transportation, what conditions changed for them that enabled them to switch modes?

\section{Availability of Outside Support}

1. Does your worksite trip reduction program use help from sources of outside support, such as a TMA, ETC network, regional commuter assistance program, or by collaborating with other nearby worksites?

Please describe. 


\section{Conditions Internal to the Worksite}

\section{Physical Facilities}

1. What type of facility is your worksite located within? For example, is your worksite a free standing building set far back from the highway with a large grounds and surface parking? Is it within a low-density office park or is it an office within a large building?

2. How long has your worksite been at its present location?

3. Do you know the primary reason for locating the organization at its present location? For example, did any of these have influence on the worksite location decision:

Rank most important (1) to least important:

Ease of employee access to worksite

Proximity to employee residences

Access to customers/clients

Centrality within urban area

Proximity to regional freight transportation (Interstate, rail)

Proximity to suppliers or other complementary industries

Proximity to similar industries

Physical characteristics of the site (i.e. utilities, facility size, etc.)

Property cost

Other

\section{Commute Trip Reduction (CTR) Program Characteristics}

1. Do you know last year's annual cost investment in the CTR program by your organization? This would include staff labor cost, services and incentives, and informational materials and promotions.

2. Are there any particular job types or employee cohorts for which CTR program services and incentives have been tailored? For example, a telecommuting program might have been developed for information specialists or a transit subsidy and work hour start and end times coordinated with bus schedules for the main office front desk receptionist.

3. What information from the CTR must be communicated to employees? How is it communicated? (i.e. regular emails or newsletters) Do you communicate directly with employees or do you prepare memoranda for management to sign or communicate?

4. Are there any trip reduction program incentives that are offered but generally not taken advantage of by employees? What are these incentives, if any? 
5. If 'yes' to question 4, is the lack of use due to disinterest or perhaps due to need for greater awareness by employees that the incentive is available? Can you explain why it did not work well?

\section{Employee Characteristics}

1. Would you describe the company's workforce in terms of the type of job classifications employed? For example (check all that apply and elaborate if necessary):

Is it primarily a unionized workforce?

Is it a highly paid workforce? Bluecollar? Whitecollar?

Professional or trades? Is it a highly skilled workforce?

Does your worksite have a large number of part-time employees? Temporary help?

Does your worksite employ primarily (circle one) Clerical? Manufacturing? Laboratory? Service? Retail? Other? Please describe

Or does your worksite employ workers with a wide range of job classifications; a mix of

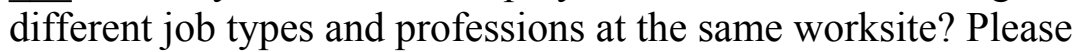
describe

2. If you had to group your worksite employees into different groups, are there distinctions among different groups that you have found to parallel their receptivity about using trip reduction alternatives? These could be distinctions by job classification, department, building floor, or anything else you might observe.

3. Is there a particular travel mode that employees gravitate toward and which seems to be more effective for your worksite?

4. If everyone at your worksite was able to easily and conveniently use alternative transportation, especially the alternative mode that works best, how many more people at your worksite do you think would use it?

5. Do you hear people ever discussing trip reduction and/or their commuting experience? What do they say?

\section{Nature of the Business}

1. The survey indicates that the primary business of your worksite $(\mathrm{Q} \# 42)$ is . Your web site indicates . Please describe

2. Is your worksite the sole location of your organization or are there other offices?

3. If there are other offices, is your commuter trip reduction program centrally managed from afar or controlled at your worksite? 
4. Your organization is (circle one) required / volunteers to comply with the Commute Trip Reduction Law.

5. How old is your organization?

6. Do employees generally take work home?

7. Must employees carry large or heavy things to and from work or to other sites during work hours: brief cases, laptops, tools, portfolios, displays, etc.?

8. How many hours per week do full-time employees typically work? Can work hours be irregular? Are there deadlines? (For example, $60 \mathrm{hr} / \mathrm{wk}$ expectation may disallow use of some transportation alternatives)

9. Do employees remain at the worksite during the day or must they travel as part of the work day?

10. Does the success of your worksite's trip reduction effort result from an intensive effort or does it happen without much effort?

11. What is the level of the interaction of employees at your worksite? Is there a lot of interaction among employees or is the nature of the work largely accomplished by employees working alone?

12. Are there any issues/problems that link your worksite to the larger community, such as employee parking on residential streets?

\section{Organizational Culture}

1. Is there any kind of interaction between your worksite and your worksite neighbors, for example carpools and vanpools established with employees of multiple worksites?

2. Organization mission statement

3. What are the core corporate values of your organization? What does the organization want to be known for?

4. What makes your worksite unique or stand out from other organizations, in general, and in particular compared to other organizations that do similar work?

5. Can you tell me the "story" of the trip reduction program at your worksite, how it began and how it has changed over time?

6. Is community relations an important issue to your organization or does your organization coexist well in the community without much need for interaction? 
7. Looking only within the population of "affected employees" as defined by the trip reduction ordinance, is there a demarcation among groups in your worksite, in which some groups are expected to participate more in the trip reduction program than other groups? For example, hourly employees with fixed schedules may be expected to rideshare or ride transit, sales force may be expected to telework, managers are expected to lead by example.

8. How would you describe the business philosophy of top management with regard to efforts to change employee travel behavior? Is it seen as (select one that fits best):

A CTR program that is adverse to the mission of the organization and the organization will do no more than necessary to comply with the law.

A CTR program that is unrelated to the mission of the organization and the organization will do no more than necessary to comply with the law.

A CTR program that is unrelated to the mission of the organization but the organization is committed to generously complying with the law because:

- _ The organization believes that if it must do something, don't do it half way but do it in the best possible way.

- IIt is important to demonstrate support for the community.

A CTR program that is philosophically aligned with the mission of the organization and so it is a natural fit to incorporate trip reduction activities into the way that business is conducted.

A CTR program that makes good business sense to the organization because it provides benefits that make the business more profitable (aids recruitment, retention, decreases tardiness/absenteeism, cuts space/parking costs) so CTR program costs are seen as a business investment.

A CTR program that is an opportunity to demonstrate corporate responsibility in mitigating industrial impacts of the business.

Other (please describe)

9. Can you describe any kind of conflict between the goals/activities of trip reduction versus the larger culture of your worksite? For example, is there a lingering sense that the tasks of trip reduction activities do not fit? An example might be a trip reduction program for employees at an automobile retailer or petroleum refinery. Or an organization may have a culture that is generally opposed to government requirements, or one that showcases prestige (and autos are symbols of that), etc.

10. Alternatively, can you describe any kind of affinity between the goals/activities of trip reduction and the larger culture of your worksite? Is there anything about the nature of your organization that you think makes it easy for employees to use alternative transportation? Have the tasks of worksite participation in the CTR program blended

well over time into the general routine of the worksite? This may relate to the type of work that your organization does or the business philosophy of the worksite.

11. What obstacles are there to using alternative transportation, simply because it is the nature of what your business does? For example, a laboratory work setting might require unpredictable 
work hours for which maintaining carpool arrangements are difficult. Are there ways that your organization has tried to overcome the obstacles to employees using alternative transportation?

12. Has the effort required of your worksite to accomplish the trip reduction program been more due to external conditions or internal conditions?

13. It would seem that the nature of TRP effectiveness is the willingness of all participants to work together, such as the ETC, ETC supervisor, top management, human resources department, parking department, employees, the union, as well as the TMA and the regulatory agency. If any group or groups are "out of sync", it has the potential to undermine the program. Are there any groups at your worksite that you consider less interested or that disagree with the philosophy of the TRP? Why is that?

14. Do you feel there is a positive alignment of views between your supervisor and top management?

15. Does your worksite have any customs, like organization parties, yearly kick-off events or special recognition ceremonies, which are related to accomplishing the trip reduction plan? Who attends? Who officiates? What is the degree of formality?

16. How would you describe your worksite's dress code? (business formal, business casual, uniform, bib overalls, jeans and sweatpants, etc.)

17. How are employees rewarded for good performance in their duties?

18. Are any parking privileges reserved for any particular tier or department of employees?

19. Does the performance evaluation of an employee at his/her overall job include degree of participation in trip reduction or is trip reduction considered outside the scope of responsibilities of the job and purely voluntary?

20. Can you describe any "champions" at your worksite who are enthusiastic about their commute alternative and who speak well as an ambassador for trip reduction?

21. Has your worksite ever nominated itself for an award relating to its trip reduction programs?

\section{Employee Transportation Coordinator}

1. How long have you served as ETC?

2. Have you worked as an ETC at other worksites or companies before this? 
3. In which department are you located?

4. What is your job title by which the employees know you? When employees see you, do they see you as the ETC or primarily as one who fulfills other functions?

5. Do you have your own office? Where is your office relative to the rest of the worksite?

6. Can you describe the organizational hierarchy of the work place and where the positions of ETC and your supervisor are located in that hierarchy? Or fax/email me a diagram?

7. Is the hierarchy of your organization more vertical or flat?

8. Where is your position in the organizational hierarchy?

9. Are you located on-site to all employees for whom you are their ETC?

10. What kinds of things would you like to have happen that would make your work as an ETC easier?

11. What support do you as the ETC need in order to accomplish your job satisfactorily?

12. Do you feel that top management believes the trip reduction program is important?

13. In what ways does management support your work?

14. Do you believe that there is adequate funding provided by your organization to accomplish its trip reduction goals?

15. Do you as an ETC have access to the person in the organization with control over the budget for the trip reduction program?

16. Is the work of the ETC your primary duty or do you serve this role less than full time? How much time per month do you spend conducting ETC duties?

17. Are your ETC duties integrated in with the other work you do or is there a clear demarcation between your ETC role and your other duties?

18. Are your ETC duties explicitly listed as part of your written job description?

19. Is your job performance evaluated in part on CTR program success?

20. How many people do you report to?

21. What type of position in the organization do you report to? 
22. Do you decide what actions to take as part of your commute trip reduction program?

23. Do you conduct your ETC duties alone or does it require coordination with other departments? Do you get their cooperation? Or do you get input and help from an employee committee?

24. Were you assigned the job as ETC or did you volunteer for it?

25. What part of your job as ETC do you like the most?

26. What part of your job as ETC do you like the least?

27. What is the most important activity of the ETC?

28. Does your work as an ETC generally require ongoing daily interaction with employees to help them find transportation options and use program services or is the program set up to be largely "self-service"? Can you describe this interaction? Do you find great variation in the needs of employees? For example, some employees need a lot of help while others participate in trip reduction but you hardly ever see them?

29. How would you rate your feelings about performing ETC duties, from "thankless task" on one extreme to feeling that the work is important and enjoying a keen sense of accomplishment on the other?

\section{Summary}

1. Overall, what factors would you say have been necessary to the success of your TRP, in order of importance?

2. What are you most proud of with regard to the TRP program?

3. Is there anything else that you would like to add, that we haven't yet discussed, that helps explain the performance of your trip reduction program? These can be both helpful conditions and obstacles.

4. Can we get a copy of your trip reduction plan? Are there any other written worksite policies regarding the TRP? Brochures or other materials made in-house? Electronic copies, emails or directions to a web site address would be fine.

Thank you very much for your time. The information you have shared has been very helpful. This concludes my questions. At this time, is there anything you would like to ask me about the study? 
After I write this case study, I will give it for you to review. What is the best way to get a draft to you?

Thanks again. Have a good day. 